\title{
FLORA DA SERRA DO CIPÓ, MINAS GERAIS: BRIÓFITAS (ANTHOCEROTOPHYTA, BRYOPHYTA E MARCHANTIOPHYTA $)^{1}$
}

\author{
OLGA YANO \& DENILSON FERNANDES PERALTA
}

Instituto de Botânica, Caixa Postal 68041, 04045-972 São Paulo, SP, Brasil

\begin{abstract}
Flora of Serra do Cipó, Minas Gerais: bryophytes (Anthocerotophyta, Bryophyta and Marchantiophyta)]. In Brazil the bryophyte researches are working in yours states of origin. There are several small floristic works to Brazil but works with a big number of species with descriptions and illustration for all taxa are few. The Serra do Cipó is a high diversity region, and the bryophyte floristic treatment inside the Fanerogamic Flora plan is a great opportunity. This treatment include 237 species and four varieties, distributed in two families, two genera and two species of Anthocerotophyta, 34 families, 67 genera e 142 species and four varieties of Bryophyta and 21 families, 47 genera and 93 species of Marchantiophyta.
\end{abstract}

Key words: Bryophytes, Taxonomy, Campo Rupestre.

Resumo - [Flora da Serra do Cipó, Minas Gerais: briófitas (Anthocerotophyta, Bryophyta e Marchantiophyta)]. O Brasil conta com poucos trabalhos de levantamento de briófitas sendo que os pesquisadores existentes estão empenhados em realizar levantamentos florísticos no estado onde estão radicados, existem vários pequenos tratamentos florísticos para o território nacional, porém trabalhos que trazem grande número de espécies e providenciam chaves descrições e ilustrações são raros. A Serra do Cipó pertence a uma região de alta diversidade e, a existência de um plano para a preparação da Flora é uma ótima oportunidade de providenciar um tratamento que envolve um grande número de espécies e de divulgar a diversidade das briófitas brasileiras. Estão sendo apresentadas 237 espécies e quatro variedades, sendo agrupados em duas famílias, dois gêneros e duas espécies de Anthocerotophyta, 34 famílias, 67 gêneros e 142 espécies e quatro variedade de Bryophyta e 21 famílias, 47 gêneros e 93 espécies de Marchantiophyta.

Palavras-chave: Briófitas, Taxonomia, Campo Rupestre.

\section{Introdução}

O Brasil conta com poucos trabalhos de levantamento de briófitas sendo que os pesquisadores existentes estão empenhados em realizar levantamentos florísticos no estado onde estão radicados (Yano 1998), menor ainda é o número de floras que incluem as briófitas.

Os pesquisadores brasileiros utilizam para identificar as espécies ocorrentes no território nacional, além das obras princeps, as floras de países próximos, principalmente a Flora de Musgos do México (Sharp et al. 1994), Flora da América Central de Allen (2002, 2004 e 2010) e os inúmeros trabalhos sobre revisão de gêneros ou famílias.

No Brasil existem vários pequenos tratamentos, porém trabalhos que trazem grande número de espécies e providenciam chaves descrições e ilustrações são raros.

Dessa maneira os trabalhos onde são apresentadas chaves e ilustrações são conhecidos para o Brasil somente o livro de Gradstein \& Costa (2003), sobre hepáticas do Brasil, onde são apresentadas chaves para 600 táxons da flora brasileira, cerca da metade apresenta ilustrações e são apresentadas descrições das famílias e gêneros, mas não para espécies; a flora de Goiás e Tocantins (Yano \& Peralta 2007, 2008), onde são apresentadas chaves, descrições e ilustrações para 228 táxons e finalmente estão em andamento a Flora de Briófitas do Estado de Santa Catarina e a Flora de Briófitas do Distrito Federal.

São obras monumentais também os trabalhos de Gradstein et al. (2001) onde são apresentadas chaves e descrições para todos os gêneros de briófitas ocorrentes na Região Neotropical e Costa et al. (2010) no Manual de Briologia para o estado do Rio de Janeiro, onde são apresentadas chaves, descrições e ilustrações para 301 gêneros ocorrentes neste estado.

Churchill (1994) enfatiza a importância de floras locais, argumentando que mesmo existindo críticas sobre floras em regiões tropicais como prematuras e introdutórias de erros, essas devem ser realizadas. Estas floras, quando bem conduzidas, introduzem boa quantidade de amostras em herbários para servir de testemunho e futuramente embasar estudos de taxonomia e distribuição geográfica. Um trabalho taxonômico em nível continental ou mundial é basicamente realizado sobre material de herbários, uma vez que o autor, na maioria das vezes, não possui financiamento ou tempo hábil para as coletas necessárias. Através da análise destes materiais é possível que se eleja, quando necessário, uma área rica no grupo estudado hot pots para a realização de coletas e estudos in situ.

1 Trabalho realizado segundo planejamento apresentado por Giulietti et al. (1987). 
Pois quando possuirmos pessoal qualificado para revisar as espécies tropicais provavelmente grande parte da vegetação existente terá desaparecido (Churchill 1994).

Existem cerca de 15.100 espécies de briófitas no mundo, das quais 10.000 são musgos, 5.000 hepáticas e 100 antóceros (Gradstein et al. 2001, Frahm 2003). Para o Brasil já foram listadas, principalmente nos catálogos de Yano (1981, 1984a, 1989, 1995, 2006 e 2010), cerca de 3.200 espécies de briófitas, sendo que destas 1.521 foram listadas no Catálogo das plantas e fungos do Brasil (Forzza et al. 2010).

Esta estimativa para o Brasil baseia-se em nomes citados em publicações e herbários, com alguns nomes que necessitam ser revistos. Parece razoável, porém, tratar estas estimativas como provável número mínimo de espécies que ocorrem no Brasil. Neste caso, o Brasil possui aproximadamente $20 \%$ de todas as briófitas conhecidas no mundo (Shepherd 2003).

As 3.200 espécies de briófitas já catalogadas para o Brasil e os 140.000 exemplares depositados em coleções científicas apontam para uma alta diversidade neste grupo de plantas e uma significativa representação em herbários (Costa \& Pôrto 2003). Entretanto, quando se verifica que há estados da federação onde coletas de exemplares deste grupo foram raras e esporádicas, aliados aos estados onde houve coletas mais freqüentes, verifica-se que ainda há trechos pouco ou não explorados e que são poucos os botânicos ou coletores que têm a atenção voltada para a coleta de exemplares de briófitas, podendo-se afirmar com segurança que ainda há muito para ser coletado, estudado e descrito (Costa \& Pôrto 2003).

Desde a preparação da Conferência Rio-92 houve intensos esforços de compilação de conhecimento e informações da diversidade biológica, em escala local e global. O documento central que reuniu estas informações (Groombridge 1992) foi produzido pelo Centro de Monitoramento da Conservação Mundial (WCMC) em conjunto com o Museu de História Natural de Londres, a União Mundial de Conservação (IUCN), o Programa das Nações Unidas para o Ambiente (UNEP), o Fundo Mundial para a Natureza (WWF) e o World Resources Institute (WRI) (Lewinsohn \& Prado 2000).

Lewinsohn \& Prado (2000) realizaram um extenso trabalho de pesquisa sobre o conhecimento da diversidade das espécies animais e vegetais que ocorrem no Brasil e chegaram a uma conclusão geral de que embora o Brasil seja privilegiado por possuir um sistema de recursos humanos e de instituições extenso e consolidado, o conhecimento razoável de nossa biodiversidade demanda ainda um grande esforço, maior ao despendido até o momento. A maioria dos táxons, gêneros, e muitas vezes famílias, necessitam de revisão. O número de especialistas em atividade foi considerado insuficiente da mesma forma que os acervos científicos e bibliográficos, e o grau de coleta foram considerado deficiente para a maioria dos biomas brasileiros em todos os táxons, com exceção de plantas vasculares.

A Serra do Cipó pertence a uma região de endemismo estimado em 48\% (Delgadillo 1994) e está localizada na região sudeste do Brasil, um dos dez centros de alta diversidade e endemismo da América Tropical (Tan \& Pócs 2000). Para esta área existe apenas o trabalho de Yano (1987) que apresenta uma listagem de 19 táxons, e tendo em vista o grande número de amostras coletadas recentemente nesta área e a oportunidade de publicar a flora dentro do veículo disponibilizado pela Universidade de São Paulo. O objetivo deste trabalho foi providenciar 0 tratamento dos táxons de briófitas existentes na Serra do Cipó.

Algumas das espécies encontradas na Serra do Cipó foram apresentadas por Gradstein \& Costa (2003) e Costa et al. (2011) como pouco conhecidas para o Brasil, acreditamos que este fato se deve principalmente pelo atraso, quando comparados as fanerógamas, na coleta e documentação de espécies de briófitas do Brasil. Dessa maneira, este trabalho irá acrescentar muitas informações no conhecimento da distribuição geográfica dos táxons tratados.

\section{Métodos}

Este tratamento está baseado no planejamento apresentado por Giulietti et al. (1987), porém para as briófitas não serão apresentados por família, mas num tratamento único envolvendo as três Divisões: Anthocerotophyta, Bryophyta e Marchantiophyta. Seguindo-se a formatação adotada nas últimas famílias publicadas.

Durante a apresentação taxonômica, quando a família possui apenas um gênero que ocorre na Serra do Cipó está sendo apresentada apenas a descrição do gênero. As divisões, famílias, gêneros e espécies estão organizados em ordem alfabética.

A literatura utilizada para identificação das espécies é apresentada, conforme modelo da Flora, no tópico Bibliografia básica logo após a descrição da família, os termos utilizados nas descrições seguem o Glossário Briológico (Ponzo et al. 2006).

Os sistemas de classificação adotados foram os de Buck \& Goffinet (2000) para Bryophyta, tratando Octoblepharum que está sendo tratado em Leucobryaceae, e adotando as modificações propostas por Pedersen (2005) e Spence \& Ramsay (2005) para Bryaceae, Stotler \& Crandall-Stotler (2005) para Anthocerotophyta e Crandall-Stotler \& Stotler (2000) para Marchantiophyta.

\section{Resultados}

Estão sendo apresentadas 237 espécies e quatro variedades, sendo agrupados em duas famílias, dois gêneros e duas espécies de Anthocerotophyta, 34 famílias, 67 gêneros e 142 espécies e quatro variedade de Bryophyta e 21 famílias, 47 gêneros e 93 espécies de Marchantiophyta. 
Flora da Serra do Cipó, Minas Gerais: Briófitas (Anthocerotophyta, Bryophyta e Marchantiophyta)

\section{ANTHOCEROTOPHYTA}

Os gametófitos desta Divisão são multilobulados, apresentando 1-8 cloroplastos por célula, os oleocorpos são simples e inconspícuos e nunca apresentam escamas na superfície ventral, apenas rizóides. Podem apresentar cavidades mucilaginosas no tecido do talo e os órgãos reprodutivos estão sempre imersos e após a fecundação o esporófito longo-cilíndrico e de crescimento contínuo e possui apenas pé e cápsula. $O$ esporófito apresenta estômatos, columela e os esporos são formados continuamente.
Comumente conhecidos como antóceros são citados para áreas abertas, protegidas do vento e luminosidade excessiva, ocorrem normalmente em locais muito úmidos como solo, barranco e tronco de árvores, porém sem contato com água corrente. $\mathrm{Na}$ Região Neotropical existem três famílias, sete gêneros e 30 espécies, no Brasil três famílias, seis gêneros e 23 espécies.

$\mathrm{Na}$ Serra do Cipó foram encontradas duas famílias, dois gêneros e duas espécies $(8,7 \%$ das que ocorrem no Brasil).

Bibliografia básica - Gradstein \& Costa (2003); Gradstein et al. (2001); Hässel de Menéndez (1962); Hell (1969); Schuster (1992); Yano (2008, 2011); Yano \& Peralta (2008).

\section{Chave para as famílias}
1. Elatérios presentes (unicelulares com espessamentos espiralados); invólucro longo (ca. 3-4/10 compr. da cápsula); estômatos ausentes
1'. Pseudo-elatérios presentes (2-3 células, espessamentos irregulares); invólucro curto (ca. 1-2/10 compr. da cápsula); estômatos presentes Dendrocerotaceae Notothyladaceae

\section{Dendrocerotaceae}

Esta família é bastante comum em áreas de Floresta Atlântica e na Serra do Cipó apresentou apenas uma amostra analisada. A família é reconhecida principalmente pelo longo invólucro que envolve a cápsula e os elatérios numerosos. Possui dois gêneros e 11 espécies citadas para o Brasil; na Serra do Cipó ocorre apenas o gênero Nothoceros.

Bibliografia básica - Gradstein \& Costa (2003); Gradstein et al. (2001); Hässel de Menéndez (1962); Hell (1969); Schuster (1992); Yano \& Peralta (2008).

\section{Nothoceros (R.M. Schust.) Hasegawa}

Gametófitos talosos, irregulares, verdeescuros, com várias camadas de células, tecido do talo não diferenciados, sem cavidades, margem do talo ondulada, colônias de Nostoc visíveis como pontos escuros no talo. Cloroplastos 2-4 por célula, anterídios e arquegônios imersos no talo e solitários. Esporófito emergente, tornando-se ereto, invólucro longo, cápsula longo a longo-filiforme, columela presente, estômatos ausentes na parede da cápsula, elatérios presentes. Esporos verdes.

1.1. Nothoceros vincentianus (Lehm. \& Lindenb.) J.C. Villarreal, Bryologist 113(1): 111. 2010.

Fig. $1 \mathrm{~A}-\mathrm{C}$

Gametófitos talosos, irregulares, margens onduladas. Cloroplastos 2-4 por célula. Células epidérmicas sem espessamentos, anterídios e arquegônios imersos no talo e solitários. Esporófito emergente, tornando-se ereto, superfície lisa, invólucro longo (ca. 3-4/10 compr. cápsula), cápsula longo-filiforme, ca. $100 \mathrm{~mm}$, columela presente, estômatos ausentes, elatérios presentes (unicelulares, espessamentos espiralados). Esporos ornamentados, verdes.

Material examinado: Minas Gerais, Santana do Riacho, Serra da Bandeirinha, O. Yano \& Wanderley 10899 (SP220592).

Ocorre nos estados de PE, RJ, SC e SP. Na Serra do Cipó, cresce em solo argiloso. Esta é uma espécie bastante citada para áreas de Floresta Atlântica, principalmente para margens de riachos. As outras três espécies deste gênero citadas para o Brasil necessitam de revisão uma vez que nunca mais foram re-analisadas deste sua publicação em 1916 por Stephani.

\section{Notothyladaceae}

Esta família é bastante comum e ocorre na maioria dos estados brasileiros, porém na Serra do Cipó apresentou apenas uma amostra analisada. É reconhecida principalmente pelo curto invólucro que envolve a cápsula e os pseudo-elatérios e esporos de coloração amarelo-parda. No Brasil ocorrem dois gêneros e 6 espécies; na Serra do Cipó ocorre apenas o gênero Phaeoceros.

Bibliografia básica - Gradstein \& Costa (2003); Gradstein et al. (2001); Hässel de Menéndez (1962); Hell (1969); Schuster (1992); Yano \& Peralta (2008).

\section{Phaeoceros Prosk.}

Gametófitos talosos, em rosetas bem delimitadas ou talos irregulares, verde-escuros ou pretos, várias camadas em espessura, nervura central ausente, tecido do talo não diferenciado, cavidades ausentes, margem do talo ondulada ou crispada, 

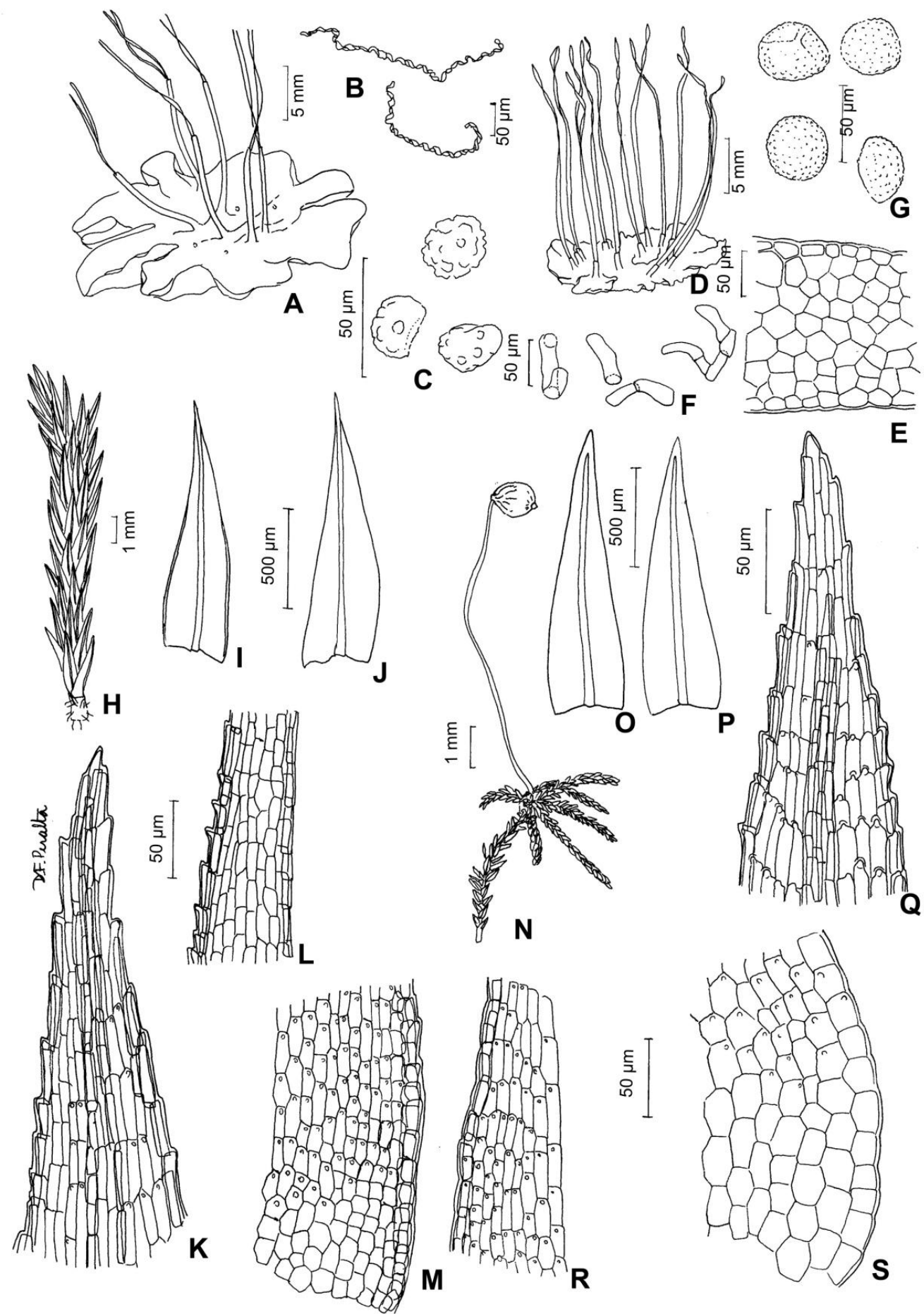

Fig. 1. Nothoceros vincentianus (Lehm. \& Lindenb.) J.C. Villarreal. A. aspecto do gametófito. B. elatérios. C. esporos. Phaeoceros laevis (L.) Prosk. D. aspecto do gametófito. E. secção transversal do talo. F. pseudo-elatérios. G. esporos. Philonotis sphaerocarpa (Hedw.) Brid. H. hábito do gametófito. I-J. filídios. K. células do ápice do filídio. L. células da margem e lâmina do filídio. M. células da base do filídio. Philonotis uncinata (Schwägr.) Brid. N. aspecto do gametófito. O-P. filídios. Q. células do ápice do filídio. R. células da margem e lâmina do filídio. S. células da base do filídio (A-C. O. Yano \& Wanderley 10899; D-G. O. Yano 481; H-M. Pirani et al. 5555; N-S. O. Yano 484). 
colônias de Nostoc presentes (visível como pontos escuros no talo). Cloroplastos 2-4 por célula. Células epidérmicas sem espessamentos, anterídios e arquegônios imersos no talo e agregados em câmaras. Esporófito emergente, tornando-se ereto, superfície lisa, invólucro curto. Cápsula longo-filiforme, columela presente, estômatos presentes. Pseudoelatérios presentes. Esporos amarelos.

1.1. Phaeoceros laevis (L.) Prosk., Bull. Torrey Bot. Club 78(4): 346. 1951

Fig. $1 \mathrm{D}-\mathrm{G}$

Gametófitos talosos, irregulares, margem do talo ondulada ou crispada. Cloroplastos 2-4 por célula. Células epidérmicas sem espessamentos, anterídios e arquegônios imersos no talo e agregados em câmaras. Esporófito emergente, tornando-se ereto, superfície lisa, invólucro que envolve a cápsula curto (ca. 1-2/10 compr. da cápsula). Cápsula longofiliforme, ca. 40-60 mm, columela presente, estômatos presentes. Pseudo-elatérios presentes (2-3 células, espessamentos irregulares). Esporos ornamentados, amarelos.

Material examinado: Minas Gerais, Conceição do Mato Dentro, O. Yano 481 (SP132038); Vital 7589 p.p. (SP132816).

Associada a Fossombronia porphyrorhyza (Nees) Prosk. Ocorre no Distrito Federal e nos estados do AM, BA, DF, ES, GO, MG, MS, PE, RJ, RS, SC, SP e TO. Na Serra do Cipó, cresce em solo. É uma espécie comum e freqüentemente citada em levantamentos, difere das outras duas espécies do gênero (Phaeoceros bulbiculosus (Brotero) Prosk. e Phaeoceros carolinianus (Michx.) Prosk.) pois é a única que apresenta a superfície externa do esporo denticulada.

\section{BRYOPHYTA}

Os gametófitos desta Divisão apresentam simetria radial, dística ou em fileiras, sempre apresentando filídios, caulídio e rizóides. Os filídios possuem comumente uma região central chamada de costa análoga a uma nervura. As estruturas reprodutivas estão rodeadas por filídios livres e apresentando paráfises abundantes. O esporófito é fotossintetizante quando jovem e se alonga antes da diferenciação da cápsula, a parede da cápsula é normalmente espessada e possui estômatos e columela. A dispersão dos esporos é comumente realizada pelo opérculo e auxiliada pelos dentes do peristômio.

Comumente conhecidos como musgos os gametófitos desta Divisão são extremamente comuns, ocorrendo desde os trópicos (onde atingem grande diversidade) até os ambientes árticos, são encontradas em todos os substratos existentes como rochas, solo, tronco de árvores vivas e mortas, sobre folhas, desde ambientes aquáticos (exceto marinho) até desérticos. Na Região Neotropical existem 41 famílias 188 gêneros e 1350 espécies; no Brasil 39 famílias, 147 gêneros e 988 espécies.

$\mathrm{Na}$ Serra do Cipó foram encontradas 34 famílias, 69 gêneros e 140 espécies (8,2 \% do número de espécies que ocorrem no Brasil).

Bibliografia básica - Buck (1998, 2003); Costa et al. (2010); Crum (1994); Frahm (1991); Gradstein et al. (2001); Ireland \& Buck (1994, 2009); Ochi (1980, 1981); Peralta \& Yano (2010); Pursell (2007); Reese (2003); Sehnem (1978); Sharp et al. (1994); Vital (1980); Yano (1979, 1984b, 1985, 1986, 1992, 2011); Yano \& Mello (1989); Yano \& Oliveira-e-Silva (1997); Yano \& Peralta (2007, 2009); Yano et al. (1985); Zander (1993).

Chave para as famílias

1. Células dos filídios dispostas em um retículo de células verdes, estreitas que se alternam com células grandes, hialinas; ramificações terminais do caulídios dispostas em rosetas Sphagnaceae

1'. Células dos filídios de uma única forma (verde) ou, se em duas formas, sem ramificações dispostas em rosetas.

2. Disposição dos filídios em três fileiras, dística ou aparentemente dística (filídios aplainados).

3. Caulídios e ramificações prostradas; filídios dimórficos entre laterais e dorsais.

4. Costa dupla

4'. Costa simples.

5. Margem dos filídios bordeada, costa subpercurrente, células da lâmina mamilosas

5. Margem dos filídios não bordeada, costa excurrente, células da lâmina lisas

3'. Caulídios e ramificações eretas ou caulídios rizomatosos e ramificações ascendentes ou pendentes;

filídios uniformes ou com diferenciação entre laterais e ventrais.

6 . Filídios em três fileiras (2 laterais, 1 ventral)

6 '. Filídios em duas fileiras, dísticos ou aplainados.

7. Filídios aplainados

7’. Filídios dísticos.

8. Caulídios secundários eretos; filídios apresentando lâmina vaginante

8'. Caulídios secundários pendentes; filídios naviculados a canaliculados

2'. Disposição dos filídios radial.

9. Caulídios e ramificações eretas.

Pilotrichaceae p.p.

Mniaceae

Neckeraceae 
10. Costa estreita.

11. Células da lâmina hexagonais a fusiformes, sem papilas.

12. Margem com células alongadas e formando margem, secção transversal do filídio com células não infladas; costa sem diferenciação; dentes do peristômio alternos Bryaceae

12'. Margem com células sem diferenciação, secção transversal do filídio com células infladas; costa diferenciada; dentes do peristômio quando presentes opostos Funariaceae

11'. Células da lâmina isodiamétricas a retangulares, sem papilas ou papilosas.

13. Células alares infladas.

14. Células alares formando região ampla (cancelina), translúcida

14'. Células alares formando proeminências laterais (aurículas), coloridas Dicranaceae p.p.

13'. Células alares não infladas.

15. Células da lâmina oblongo-retangulares, papilas únicas, distais

Bartramiaceae

15'. Células da lâmina isodiamétricas a longo-hexagonais, sem papilas ou

pluripapilosas.

16. Esporófito com pescoço diferenciado, comprimento igual ou maior que a cápsula.......

Bruchiaceae

16'. Esporófito com pescoço não diferenciado.

17. Costa subpercurrente

17'. Costa percurrente ou excurrente.

18. Secção transversal da costa diferenciada apresentando células guias e estereídios

Rhachitheciaceae

18'. Secção transversal da costa sem diferenciação

Pottiaceae

ando $1-2 / 3$ ou toda a largura do filídio.

10'. Costa larga, ocupando $1 / 3$ a $2 / 3$ da largura do filídio.

20. Base dos filídios vaginante, formando bainha

Polytrichaceae

20'. Base dos filídios não vaginante, algumas vezes com células infladas e coloridas ....... Dicranaceae p.p.

19'. Costa ocupando toda a largura do filídio, verde-pálida a branca.

21. Filídios lanceolados, ápice tubuliforme, região alar não diferenciada, costa em secção transversal apresentando clorocistos com 4 ângulos

Leucobryaceae

21'. Filídios lingulados, ápice plano, região alar diferenciada formando aletas, costa em secção transversal apresentando clorocistos com 3 ângulos

9'. Caulídios e ramificações prostradas, pendentes ou ascendentes.

22. Caulídios rizomatosos e ramificações ascendentes.

23. Ramificações dendróides, 1-2 irregularmente pinadas.

24. Células da lâmina lisa, sem paráfilos

Neckeraceae

24'. Células da lâmina papilosas, paráfilos presentes Thuidiaceae

23'. Ramificações simples.

25. Células da lâmina longo-hexagonais a lineares.

26. Costa única

Pterobryaceae

26'. Costa ausente ou curta e dupla.

27. Costa ausente, ápice pilífero, avermelhado; filídios espalhados.

27'. Costa curta e dupla, ápice acuminado, verde; filídios imbricados.

Hedwigiaceae

28. Células da lâmina prorulosas

Pteryginandraceae

28'. Células da lâmina lisas

Entodontaceae

25'. Células da lâmina isodiamétricas.

29. Filídios linear-lanceolados, margem denteada, biestratificada .......................... Rhizogoniaceae

29'. Filídios oblongo-lanceolados a lanceolados, margem inteira ou denteada, uniestratificada

Orthotrichaceae

22'. Caulídios e ramificações prostradas ou caulídios prostrados e ramificações pendentes.

30. Costa única.

31. Células alares diferenciadas.

32. Células alares mais concentradas num dos lados do filídio, gametófitos robustos, filídios difíceis de destacar .....

Stereophyllaceae

32'. Células alares igualmente distribuídas num dos lados do filídio, gametófitos delicados quebrando-se ao retirar os filídios

Fabroniaceae

31'. Células alares não diferenciadas.

33. Ramificações secundárias pendentes, células da lâmina longo-hexagonais a lineares, sem papilas ou papilosas, costa simples

Meteoriaceae

33'. Ramificações prostradas, sub-ascendentes ou pêndulas, células da lâmina fusiformes até lineares, costa simples, freqüentemente projetando-se por um pequeno espinho.

Brachytheciaceae

30'. Costa ausente ou dupla, ou dupla e curta.

34. Costa dupla

35. Costa dupla e curta ( $1 / 5$ compr. do filídio).

36. Margem dos filídios bordeada, células rômbicas

Pilotrichaceae p.p.

36'. Margem dos filídios não bordeada, células longo-hexagonais a lineares

Hypnaceae p.p.

35'. Costa dupla e longa ( $3 / 5$ ou subpercurrente) Pilotrichaceae

34'. Costa ausente. 
Flora da Serra do Cipó, Minas Gerais: Briófitas (Anthocerotophyta, Bryophyta e Marchantiophyta)

37. Ramificações pendentes

37'. Ramificações prostradas.

38. Células alares não diferenciadas.

39. Filídios acuminados, células da lâmina longo-hexagonais; seta longa, esporófito emerso.

39'. Filídios apiculados, células hexagonais a isodiamétrica; seta curta, esporófito imerso.

38'. Células alares diferenciadas.

40. Células alares não infladas, pseudoparáfilos presentes

40 '. Células alares infladas, pseudoparáfilos ausentes

Lembophyllaceae

.. Leucomiaceae

Erpodiaceae

Hypnaceae p.p. Sematophyllaceae

\section{Bartramiaceae}

É uma família bastante comum no Brasil, caracterizada principalmente pelas papilas nos ângulos distais das células dos filídios. Ocorre principalmente em barrancos próximos a água corrente. No Brasil ocorrem cinco gêneros e 34 espécies; na Serra do Cipó ocorre apenas o gênero Philonotis.

Bibliografia básica - Gradstein et al. (2001); Sharp et al. (1994); Yano \& Peralta (2009).

\section{Philonotis Brid.}

Gametófitos acrocárpicos, medianos ou robustos, formando tufos. Caulídios primários eretos, tomentosos, ramos secundários ausentes ou raros. Filídios lanceolados, bilateralmente simétricos, planos, espiralados, planos quando secos. Costa única, percurrente ou excurrente, estreita (ca. 1/10 a 1/20 da largura do filídio), secção transversal sem células diferenciadas, lâmina do filídio sem lamelas, ápice acuminado, margem do filídio plana, denticulada, não bordeada, células da lâmina retangulares, pouco alongadas, papilosas, parede celular delgada, reta, células da base iguais as da lâmina. Seta longa, reta, marrom-dourada, lisa. Cápsula exserta, inclinada, assimétrica, urna globosa, rômbica, superfície quando seca estriada, Opérculo cônico. Peristômio presente, duplo, dentes do exóstomo não torcidos espiraladamente, inteiros, endóstomo bem desenvolvido, ciliado. Caliptra pequena, glabra.

Chave para as espécies

1. Costa excurrente, denticulada

1.1. P. sphaerocarpa

1 '. Costa subpercurrente, lisa 1.2. P. uncinata

1.1. Philonotis sphaerocarpa (Hedw.) Brid., Bryol. Univ. 2: 25. 1827.

Fig. $1 \mathrm{H}-\mathrm{M}$

Filídios lanceolados, ápice longo-acuminado, células da lâmina longo-hexagonais, papilas distais nítidas, fileira de células da margem dupla, duplo denticulado, costa excurrente, denticulada.

Material examinado: Minas Gerais, Cardeal Mota, APA Morro da Pedreira, Pirani et al. 5555 (SP389346, SPF); Santana do Riacho, Cachoeira Farofa, O. Yano \& Wanderley 10646 p.p. (SP220341).

Associada a Rosulabryum huillense (Wilw. \& Duby) Ochyra e Callicostella pallida (Hornsch.) Ångstr. Ocorre nos estados do AM, BA, CE, MT, RJ, SC e SP. $\mathrm{Na}$ Serra do Cipó, cresce em rocha e paredão úmido em cachoeira. $P$. sphaerocarpa pode ainda ser confundida com P. cernua (Wilson) D.G. Griffin \& W.R. Buck e $P$. longiseta (Michx.) E. Britton, pelo formato do filídio e costa percurrente. Porém além de $P$. cernua não apresentar peristômio ambas são autóicas e $P$. sphaerocarpa é dióica. Esta é a primeira ocorrência para Minas Gerais.

1.2. Philonotis uncinata (Schwägr.) Brid., Bryol. Univ. 2: 221. 1827.

Fig. $1 \mathrm{~N}-\mathrm{S}$

Filídios lanceolados, ápice acuminado, células lâmina longo-hexagonais a retangulares, papilas distais pouco nítidas, fileira de células da margem simples, denticulada, costa subpercurrente.

Material examinado: Minas Gerais, Conceição do Mato Dentro, O. Yano 484 (SP135453); Santana do Riacho, O. Yano \& Wanderley 10921 (SP220614).

Ocorre nos estados do AC, AM, BA, CE, DF, ES, GO, MG, MS, MT, PA, PB, PE, PI, PR, RJ, RO, RS, SC, SP e TO. Na Serra do Cipó, cresce em barranco e solo úmido. Esta espécie é muito comum a amplamente distribuída, a margem do filídio finamente denticulada a diferencia de P. glaziovii (Hampe) D.G. 
Griffin \& W.R. Buck que apresenta a margem denteada.

\section{Brachytheciaceae}

Gametófitos pleurocárpicos, medianos ou robustos, formando tapetes. Caulídios primários prostrados, ramos secundários ascendentes, ou pendentes, sem paráfilos ou pseudoparáfilos. Filídios lanceolados, espiralados. Costa única, até $1 / 2$ ou $3 / 4$ compr. do filídio, estreita, ápice pilífero, ou agudo, margens do filídio plana, denticulada, não bordeada, células da lâmina longo-hexagonais, lisas, parede celular delgada, região alar, 1-10 fileira de células, muito infladas e coloridas de marrom a laranja.
Dióicos, monóicos ou autóicos. Seta longa, reta, marrom-dourada, rugosa. Cápsula inclinada, ou horizontal, assimétrica, urna ovóide, rômbica. Opérculo rostrado. Peristômio duplo. Caliptra glabra, não plicada.

É uma família bastante comum no Brasil, caracterizada principalmente pela costa bastante pronunciada e freqüentemente protuberante dorsalmente e as células dos filídios longas e lisas. Ocorre nos mais variados substratos. No Brasil ocorrem 14 gêneros e 39 espécies; na Serra do Cipó ocorrem dois gêneros, ambos característicos de ambientes abertos e ventilados.

Bibliografia básica - Gradstein et al. (2001); Sharp et al. (1994); Yano \& Peralta (2009).

Chave para os gêneros

1. Gametófitos prostrados com ramificações sub-ascendentes, terrestres. Filídios lanceolados 1. Brachythecium

1'. Gametófitos pêndulos, corticícolas. Filídios ovados 2. Squamidium

\section{Brachythecium Schimp.}

Gametófitos pleurocárpicos, medianos, formando tapetes. Caulídios primários prostrados, poucos rizóides, ramos secundários ascendentes. Filídios lanceolados, bilateralmente simétricos, côncavos, espiralados, planos quando secos, Costa única, $1 / 2$ ou $3 / 4$ compr. do filídio, estreita, secção transversal sem células diferenciadas, lâmina do filídio sem lamelas, ápice acuminado, margem plana, denticulada, não bordeada, células da lâmina longo-hexagonais, muito alongadas, lisas, parede celular delgada, reta, células da base do filídio 1-5 fileira de células quadráticas, incolores. Seta longa, reta, marrom-dourada, rugosa. Cápsula exserta, inclinada, assimétrica, urna ovóide, rômbica, superfície lisa quando seca, ânulo presente. Opérculo rostrado, peristômio duplo, dentes do exóstomo perfurado, membranáceo, com barras transversais, endóstomo bem desenvolvido, ciliado. Caliptra pequena, glabra.

1.1 Brachythecium ruderale (Brid.) W.R. Buck, Mem. New York Bot. Gard. 82: 240. 1998.

Fig. 2 A-G

Gametófitos prostrados com ramificações sub-ascendentes. Filídios lanceolados, ápice longoacuminado, margem denticulada, células da lâmina longo-hexagonais a lineares, região alar pouco diferenciada, costa simples, $1 / 2$ ou $3 / 4$ do compr.

Material examinado: Minas Gerais, Conceição do Mato Dentro, Vital 7582 (SP136552).

Ocorre no BA, ES, GO, MG, MS, PE, PR, RJ, RS, SC e SP. Na Serra do Cipó, cresce em barranco. É uma espécie comum e característica de ambientes alterados e ensolarados como margem de trilhas ou estradas.

\section{Squamidium (Müll. Hal.) Broth.}

Gametófitos pleurocárpicos, robustos. Caulídios primários prostrados, ramos secundários pendentes. Filídios lanceolados. Filídios dos ramos mais estreitos, bilateralmente simétricos, côncavos, espiralados, aparentemente em fileiras, planos quando secos, Costa única, 1/2 ou 3/4 compr. do filídio, estreita, secção transversal sem células diferenciadas, ápice do filídio pilífero, margem do filídio plana, denticulada, não bordeada, células da lâmina longo-hexagonais, muito alongadas, lisas, parede celular delgada, reta, células da base do filídio 1-10 fileira de células, muito infladas, marrons a laranja. Seta longa, rugosa. Cápsula assimétrica, urna ovóide, rômbica, superfície lisa quando seca, ânulo presente. Opérculo rostrado, peristômio duplo. Exóstomo perfurado, membranáceo e com barras transversais, endóstomo desenvolvido. Caliptra glabra.

2.1. Squamidium brasiliense (Hornsch.) Broth. in Engler \& Prantl, Natürl. Pflanzenfam. 1(3): 809. 1906.

Fig. $2 \mathrm{H}-\mathrm{M}$

Gametófitos pêndulos. Filídios ovados, ápice apiculado, margem inteira, recurvada, junto ao ápice, células da lâmina longo-hexagonais a lineares, costa simples, 3/4 do compr.

Material examinado: Minas Gerais, Conceição do Mato Dentro, Oliveira Filho 4 (SP90867); entre Morro do Pilar e Conceição do Mato Dentro, Campos et al. 13245 (SPF170924); Santana do Riacho, Serra da Bandeirinha, O. Yano \& Wanderley 10815 (SP220508) 

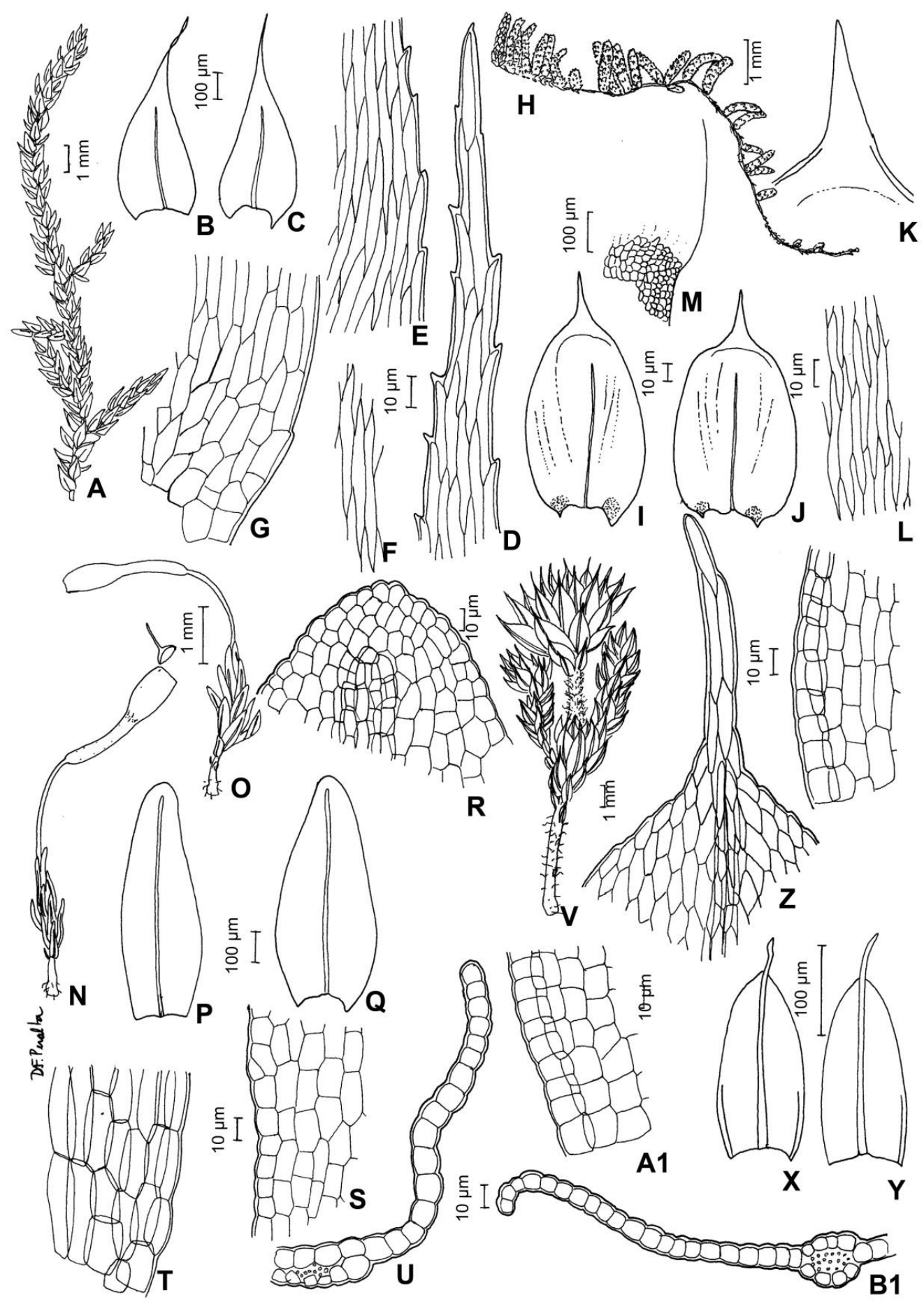

Fig. 2. Brachythecium ruderale (Brid.) W.R. Buck. A. aspecto do gametófito. B-C. filídios. D. células do ápice do filídio. E. células da margem do filídio. F, células da lâmina do filídio. G. células da base do filídio. Squamidium brasiliense (Hornsch.) Broth. H. aspecto do gametófito. I-J. filídios. K. células do ápice do filídio. L. células da lâmina do filídio. M. células da base do filídio. Trematodon heterophyllum Müll. Hal. N-O. aspecto do gametófito. P-Q. filídios. r. células do ápice do filídio. S. célula da margem do filídio. T. células da base do filídio. U. secção transversal do filídio. Brachymenium klotzchii (Schwägr.) Paris. V. aspecto do gametófito. X-Y. filídios. Z. células do ápice do filídio. W. células da margem do filídio. A1. células da base do filídio. B1. secção transversal do filídio (A-G. Vital 7582; H-M. O. Yano \& Wanderley 10815; N-U. Vital 1262; V-B1. O. Yano \& Wanderley 10721). 
Ocorre nos estados da BA, ES, MG, PE, PR, RJ, RS, SE, SC e SP. Na Serra do Cipó, cresce em tronco vivo. Esta é uma espécie bastante comum em Floresta Atlântica, principalmente em margem de florestas, comumente apresenta muitas ramificações pendentes.

\section{Bruchiaceae}

É uma família comum no Brasil, porém pouco conhecida e coletada, primariamente relacionada a áreas de planalto e altitudes elevadas, caracterizada principalmente pelos gametófitos pequenos e pelo pescoço da cápsula longo e mais largo do que a seta. Ocorre sempre em solo bem drenado e freqüentemente em locais recém abertos. No Brasil ocorrem quatro gêneros e 16 espécies; na Serra do Cipó ocorre o gênero Trematodon.

Bibliografia básica - Gradstein et al. (2001); Sharp et al. (1994); Yano \& Peralta (2009).

\section{Trematodon Michx.}

Gametófitos acrocárpicos, pequenos, delicados ou medianos, gregários ou formando tufos. Caulídios primários eretos, poucos rizóides, ramos secundários ausentes ou raros. Filídios lanceolados, bilateralmente simétricos, côncavos, espiralados, planos quando secos. Costa única, percurrente, estreita, secção transversal sem células diferenciadas, ápice do filídio obtuso, margem do filídio plana, denticulada, não bordeada, células da lâmina retangulares, quadráticas ou irregulares, isodiamétricas, lisas, parede celular delgada, reta, células da base do filídio mais claras, alongadas porém não infladas, filídios periqueciais diferenciados. Seta longa. Cápsula exserta, inclinada, assimétrica, urna piriforme ou ovóide, rômbica, superfície lisa quando seca, pescoço alongado e mais largo do que a seta, ânulo presente. Opérculo rostrado. Peristômio ausente, se presente simples. Caliptra glabra.

1.1. Trematodon heterophyllum Müll. Hal. in Brotherus, Hedwigia 34: 118. 1895, non Trematodon heterophyllus Müll. Hal., Bull. Herb. Boissier 6(1): 44. 1898 (nome supérfluo, art. 52.1 CNB).

Fig. $2 \mathrm{~N}-\mathrm{U}$

Gametófitos pequenos e formando tufos. Caulídios primários eretos. Filídios lanceolados, espiralados, planos quando secos. Costa única, percurrente, ápice do filídio obtuso, margens denticuladas, não bordeadas, células da lâmina retangulares, quadráticas ou irregulares, lisas, parede celular delgada, reta, células da base do filídio mais claras, alongadas porém não infladas, filídios periqueciais diferenciados. Seta longa. Cápsula com pescoço alongado e mais largo do que a seta.

Material examinado: Minas Gerais, Conceição do Mato Dentro, Vital 1262 (SP89612); Congonhas do Norte, Pirani et al. 5745 (SP432340).

Ocorre no estado de MG (Serra do Caraça) e RJ (Itatiaia). Na Serra do Cipó, cresce em barranco. Esta é uma importante descoberta e provavelmente a segunda após a descrição da espécie em 1895. Também foi citada por Costa et al. (2005) porém sem material examinado. Esta espécie difere das duas outras espécies mais comuns do gênero: Trematodon longicollis Michx. pelo tamanho muito menor $\mathrm{e}$ Trematodon vaginatus Müll. Hal. pela ausência de bainha amplamente invaginante dos filídios. As outras oito espécies deste gênero citadas para o Brasil necessitam urgentemente serem reavaliadas.

\section{Bryaceae}

Gametófitos acrocárpicos, pequenos e delicados, até medianos ou robustos, formando tufos. Caulídios primários eretos, tomentosos, ramos secundários ascendentes, sem paráfilos ou pseudoparáfilos. Filídios ligulados, lanceolados ou ovados, planos, ou côncavos, em fascículos (rosulados) ou espiralados. Costa única até $1 / 2$ ou $3 / 4$ compr. do filídio, percurrente (alcançando o ápice do filídio), ou excurrente (atingindo acima do ápice do filídio), estreita, ápice do filídio apiculado, pilífero, acuminado ou agudo, margens plana, inteira, denticulada ou denteada, bordeado (ca. 10-15:1 compr.), células da lâmina longo-hexagonais, lisas, parede celular delgada, reta, região alar mais claras e alongadas porém não infladas. Reprodução vegetativa bulbilhos ou gemas. Dióicos, monóicos, sinóicos ou autóicos. Seta longa, reta ou curvada, marromdourado, lisa. Cápsula pendula ou ereta, assimétrica, urna piriforme ou ovóide, rômbica. Peristômio único ou duplo. Caliptra glabra, não plicada

É uma família muito comum no Brasil, caracterizada principalmente pela costa pronunciada e as células dos filídios longas e lisas. Ocorre nos mais variados substratos e em todos os Biomas brasileiros. No Brasil ocorrem oito gêneros e 89 espécies; na Serra do Cipó ocorrem cinco gêneros, quatro característicos de ambientes abertos e Rosulabryum de áreas mais úmidas e sombreadas.

Bibliografia básica - Gradstein et al. (2001); Ochi (1980, 1981); Sharp et al. (1994); Yano \& Peralta (2009). 
1. Margem do filídio inteira na porção mediana superior.

2. Apice do filídio acuminado

2'. Ápice do filídio agudo, obtuso ou apiculado.

3. Ápice do filídio obtuso ou apiculado.

4. Ápice obtuso

4'. Ápice apiculado

3'. Ápice do filídio agudo.

5. Margem do filídio bordeado por células estreitas, muito alongadas.

6. Gametófitos pequenos, delicados; quando secos eretos a imbricados; côncavos; células da

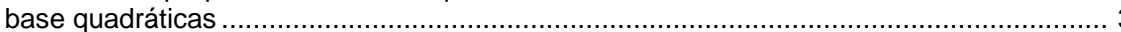

6'. Gametófitos medianos; quando secos espiralados; planos; células da base retangulares ..... 4.

5'. Margem do filídio bordeado por células estreitas, não alongadas.

7. Filídios lanceolados; verde-claros a verde-escuros; células da base retangulares; porção

mediana inferior encurvada

3. Gemmabryum p.p.

7'. Filídios oblongo-lanceolados; esbranquiçados; células da base quadráticas; porção mediana inferior plana .

2. Bryum p.p.

1'. Margem do filídio denticulada a denteada na porção mediana superior.

8. Margem na porção mediana superior denticulada.

9. Filídios lanceolados.....

9'. Filídios oblongo-lanceolados a obovados.

10. Filídios oblongo-lanceolados

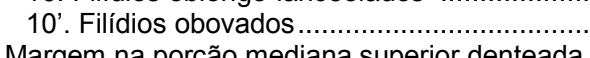

Gemmabryum p.p. 4. Ptychostomum

2. Bryum p.p.

3. Gemmabryum p.p.

1. Brachymenium

2.2. Bryum p.p.

8. Margem na porção mediana superior denteada 5. Rosulabryum

\section{Brachymenium Schwägr.}

Gametófitos acrocárpicos, pequenos, delicados ou medianos, formando tufos. Caulídios primários eretos, tomentosos, ramos secundários ascendentes. Filídios ligulados, lanceolados ou ovados, planos ou côncavos, espiralados, quando secos crispados ou planos. Costa única, 1/2 ou 3/4 compr. do filídio, percurrente ou excurrente, estreita, ápice do filídio apiculado, pilífero, acuminado ou agudo, margem dos filídios plana, denticulada ou denteada, bordeada, células da lâmina longo-hexagonais, pouco alongadas, lisas, parede celular delgada, reta, células da base do filídio mais claras, alongadas porém não infladas. Reprodução vegetativa ausente. Seta longa, reta ou curvada. Cápsula ereta, simétrica, urna piriforme ou ovóide, rômbica, superfície lisa quando seca, ânulo presente. Opérculo cônico, peristômio duplo. Caliptra glabra.

1.1. Brachymenium klotzchii (Schwägr.) Paris, Index Bryol.: 129. 1894.

Fig. 2 V-B1

Gametófitos pequenos, delicados, verde-claros a verde-escuros. Filídios oblongo-lanceolados, planos, igualmente dispostos em todo o caulídio, quando secos eretos a imbricados, pequenos (usualmente menor do que $5 \mathrm{~mm}$ compr.), bordeados por células estreitas, mas não longas, margem na porção mediana superior denticulada, porção mediana inferior encurvada, ápice do filídio agudo, costa curtoexcurrente, células da região mediana longohexagonais, células da base quadráticas. Esporófito único, cápsula ereta a subereta, pescoço não ou pouco diferenciado, peristômio duplo.

Material examinado: Minas Gerais, Santana do Riacho, Serra da Bandeirinha, O. Yano \& Wanderley 10721 (SP220415).

Ocorre nos estados do ES, PA e SP. Na Serra do Cipó, cresce sobre tronco vivo. Esta foi a única espécies desta família que ocorreu como corticícola.

\section{Bryum Hedw.}

Gametófitos acrocárpicos, pequenos, delicados, medianos ou robustos, formando tufos. Caulídios primários eretos, tomentosos, ramos secundários ascendentes. Filídios ligulados, lanceolados ou ovados, planos ou côncavos, espiralados, quando secos crispados ou planos. Costa única, $1 / 2$ ou $3 / 4$ compr. do filídio, percurrente ou excurrente, estreita, ápice do filídio apiculado, pilífero, acuminado ou agudo, margem do filídio plana, inteira, denticulada ou denteada, bordeada, células da lâmina longo-hexagonais, pouco alongadas, lisas, parede celular delgada, reta, células da base do filídio mais claras, alongadas porém não infladas. Reprodução vegetativa ausente. Seta longa, curvada. Cápsula exserta, pêndulas, assimétrica, urna piriforme ou ovóide, rômbica, superfície lisa quando seca, ânulo presente. Opérculo cônico. Peristômio duplo. Caliptra glabra.

Este gênero é caracteristicamente 0 mais amplamente distribuído e ocorre principalmente em áreas recém abertas. 
1. Margem do filídio denticulada a denteada na porção mediana superior 2.2. B. limbatum

1'. Margem do filídio inteira na porção mediana superior.

2. Ápice do filídio apiculado; verde-claros a verde-escuros

2.3. B. muehlenbeckii

2 '. Ápice do filídio agudo; esbranquiçados

2.1. B. argenteum

2.1. Bryum argenteum Hedw., Spec. Musc. Frond.: 181. 1801.

Fig. $3 \mathrm{~A}-\mathrm{F}$

Gametófitos esbranquiçados.

pequenos, delicados, Filídios oblongo-lanceolados, côncavos, igualmente dispostos em todo o caulídio, quando secos eretos a imbricados, pequenos (usualmente menor do que $5 \mathrm{~mm}$ compr.), bordeados por células estreitas, mas não longas, margem na porção mediana superior inteira, porção mediana inferior plana, ápice do filídio agudo, costa $3 / 4$ ou percurrente, células da região mediana longohexagonais, células da base quadráticas. Esporófito único, cápsula pêndula a horizontal, pescoço não ou pouco diferenciado, peristômio duplo.

Material examinado: Minas Gerais, Cardeal Mota, APA Morro da Pedreira, Pirani et al. 5560 (SP389348, SPF); Câmara 1945 p.p. (SP419659); Câmara 2017 (SP419692) Santana do Riacho, O. Yano \& Wanderley 10689 (SP220384); Córrego Taioba, O. Yano \& Wanderley 10909 (SP220602).

Ocorre nos estados da AM, AL, BA, CE, DF, ES, GO, MG, MT, PB, PE, PR, RJ, SP, RR, RS, SC e SP. Na Serra do Cipó, cresce em rocha ou barranco ou barranco na margem de riacho. Esta espécie é facilmente diferenciada pela coloração brancoprateada dos gametófitos, é amplamente distribuída e freqüentemente coloniza áreas antropizadas.

2.2. Bryum limbatum Müll. Hal., Syn. Musc. Frond. 2: 573. 1851.

Fig. 3 G-L

Gametófitos medianos, verde-claros a verdeescuros. Filídios obovados, planos, igualmente dispostos em todo o caulídio, quando secos eretos a imbricados, pequenos (usualmente menor do que 5 $\mathrm{mm}$ compr.), bordeados por células muito longas e distintas, margem na porção mediana superior denticulada, porção mediana inferior plana, ápice do filídio agudo, costa percurrente, células da região mediana fusiformes ou longo-hexagonais, células da base quadráticas. Esporófito único, cápsula pêndula a horizontal, pescoço não ou pouco diferenciado, peristômio duplo.

Material examinado: Minas Gerais, Conceição do Mato Dentro, O. Yano 522, 533, 539 (SP135480; SP135488; SP135493).
Ocorre nos estados do BA, CE, DF, ES, MG, PR, RJ, RS, SC e SP. Na Serra do Cipó, cresce em barranco na margem de riacho. É uma espécie freqüente e característica de margens de água corrente.

2.3. Bryum muehlenbeckii B.S.G., Bryol. Eur. 4: 163. 1846.

Fig. $3 \mathrm{M}-\mathrm{R}$

Gametófitos medianos, verde-claros a verdeescuros. Filídios lanceolados, côncavos, igualmente dispostos em todo o caulídio, quando secos eretos a imbricados, pequenos (usualmente menor do que 5 $\mathrm{mm}$ compr.), bordeados por células estreitas, mas não longas, margem na porção mediana superior inteira, porção mediana inferior encurvada, ápice do filídio apiculado, costa percurrente, células da região mediana longo-hexagonais, células da base quadráticas. Esporófito único, cápsula pêndula a horizontal, pescoço não ou pouco diferenciado, peristômio duplo.

Material examinado: Minas Gerais, Cardeal Mota, Câmara 1945 p.p. (SP419659).

Associada a Bryum argenteum Hedw. Ocorre no estado do PR (Foz do Iguaçu, Parque Nacional). $\mathrm{Na}$ Serra do Cipó, cresce em rocha. Esta é a primeira ocorrência para Minas Gerais.

\section{Gemmabryum J.R. Spence \& H.P. Ramsay}

Gametófitos acrocárpicos, pequenos, delicados ou medianos ou robustos, formando tufos. Caulídios primários eretos, tomentosos, ramos secundários ascendentes. Filídios ligulados ou lanceolados ou ovados, planos ou côncavos, espiralados, quando secos crispados ou planos. Costa única, $1 / 2$ ou $3 / 4$ compr. do filídio, percurrente ou excurrente, estreita, ápice do filídio apiculado, pilífero, acuminado ou agudo, margem do filídio plana, inteira, bordeada, células da lâmina longo-hexagonais, pouco alongadas, lisas, parede celular delgada, reta, células da base do filídio mais claras, alongadas porém não infladas. Reprodução vegetativa bulbilhos ou gemas. Seta longa, reta. Cápsula pêndula ou ereta, assimétrica, urna piriforme ou ovóide, rômbica, superfície lisa quando seca, ânulo presente. Opérculo cônico, peristômio duplo. Caliptra glabra. 
Flora da Serra do Cipó, Minas Gerais: Briófitas (Anthocerotophyta, Bryophyta e Marchantiophyta)

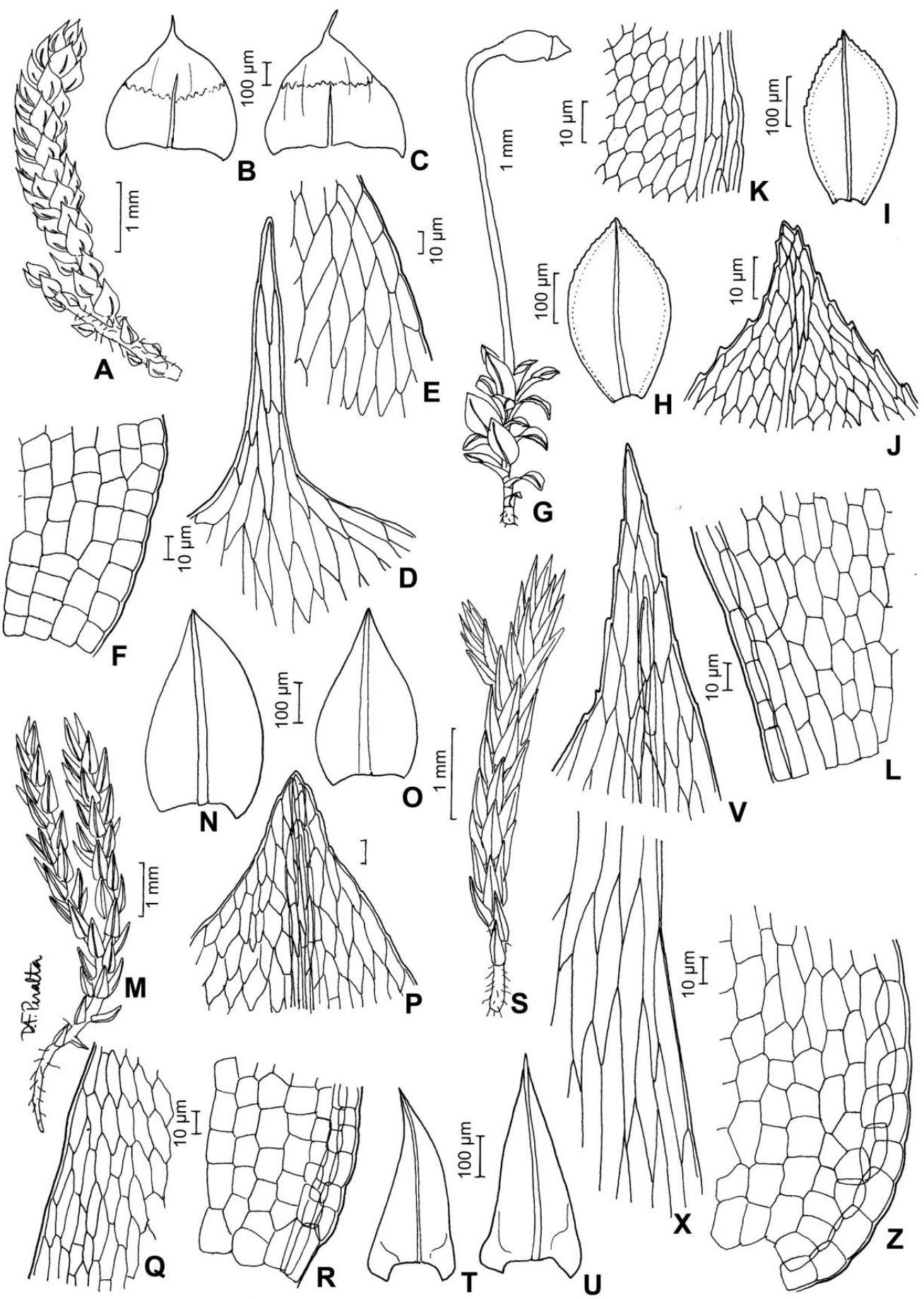

Fig. 3. Bryum argenteum Hedw. a. aspecto do gametófito. B-C. filídios. d. células do ápice do filídio. E. células da margem do filídio. F. células da base do filídio. Bryum limbatum Müll. Hal. G. aspecto do gametófito. H-I. filídios. J. células do ápice do filídio. K. células da margem do filídio. L. células da base do filídio. Bryum muehlenbeckii B.S.G. M. aspecto do gametófito. N-O. filídios. P. células do ápice do filídio. Q. células da margem do filídio. R. células da base do filídio. Gemmabryum acuminatum (Harv. in Hook.) J.R. Spence \& H.P. Ramsay. S. aspecto do gametófito. T-U. filídios. V. células do ápice do filídio. X. células da margem do filídio. Z. células da base do filídio (A-F. O. Yano \& Wanderley 10689; G-L. O. Yano 522; M-R. Câmara 1945 p.p.; S-Z. O. Yano \& Wanderley 10710 p.p.). 
1. Margem do filídio denticulada a denteada na porção mediana superior 3.3. G. subapiculatum

1'. Margem do filídio inteira na porção mediana superior.

2. Ápice do filídio acuminado 3.1. G. acuminatum

2'. Ápice do filídio agudo, obtuso ou apiculado.

3. Margem do filídio bordeado por células estreitas, muito alongadas 3.3. G. exile

3'. Margem do filídio bordeado por células estreitas, não alongadas 3.2. G coronatum

3.1. Gemmabryum acuminatum (Harv. in Hook.) J.R. Spence \& H.P. Ramsay, Phytologia 87(2): 65. 2005.

\section{Fig. 3 S-Z}

Gametófitos pequenos, delicados, verde-claros a verde-escuros. Filídios lanceolados, planos, igualmente dispostos em todo o caulídio, quando secos eretos a imbricados, pequenos (usualmente menor do que $5 \mathrm{~mm}$ compr.), bordeados por células estreitas, mas não longas, margem na porção mediana superior inteira, porção mediana inferior encurvada, ápice do filídio acuminado. Costa percurrente ou curto-excurrente, células da região mediana lineares, células da base quadráticas. Esporófito único, cápsula ereta a subereta, pescoço não ou pouco diferenciado, peristômio duplo.

Material examinado: Minas Gerais, Santana do Riacho, Serra da Bandeirinha, O. Yano \& Wanderley 10710 p.p. (SP220405).

Associada a Paracromastigum pachyrrhizon (Nees) Fulford e Dicranella hilariana (Mont.) Mitt. Ocorre nos estados de GO, RJ, RS, SC e SP. Na Serra do Cipó, cresce em solo. O hábito ereto, os filídios longo-lanceolados e imbricados e as células da lâmina do filídio muito longas são característicos desta espécie.

3.2. Gemmabryum coronatum (Schwägr.) J.R. Spence \& H.P. Ramsay, Phytologia 87(2): 66. 2005.

Fig. 4 A-G

Gametófitos pequenos, delicados, verde-claros a verde-escuros. Filídios lanceolados, côncavos, igualmente dispostos em todo o caulídio, quando secos eretos a imbricados, pequenos (usualmente menor do que $5 \mathrm{~mm}$ compr.), bordeados por células estreitas, mas não longas, margem na porção mediana superior inteira, porção mediana inferior encurvada, ápice do filídio agudo. Costa percurrente ou curto-excurrente, células da região mediana longohexagonais, células da base retangulares. Esporófito único, cápsula pêndula a horizontal, pescoço mesma largura da urna e enrugado, peristômio duplo.

Material examinado: Minas Gerais, Santana do Riacho, Córrego Taioba, O. Yano \& Wanderley 10908 (SP220601).
Ocorre nos estados do AM, AC, BA, CE, DF, FN, GO, MA, MG, MT, PA, PB, PE, PI, PR, RJ, RO, RR, RS, SC, SP e TO. Na Serra do Cipó, cresce em barranco. Esta espécie apresenta uma ornamentação muito característica na base da cápsula, que é mais larga e enrugado do que a cápsula.

3.3. Gemmabryum exile (Dozy \& Molk.) J.R. Spence \& H.P. Ramsay, Phytologia 87(2): 67. 2005.

Fig. $4 \mathrm{H}-\mathrm{M}$

Gametófitos pequenos, delicados, verde-claros a verde-escuros. Filídios oblongo-lanceolados, côncavos, igualmente dispostos em todo o caulídio, quando secos eretos a imbricados, pequenos (usualmente menor do que $5 \mathrm{~mm}$ compr.), bordeados por células muito longas e distintas, margem na porção mediana superior inteira, porção mediana inferior encurvada, ápice do filídio agudo. Costa curtoexcurrente, células da região mediana longohexagonais, células da base quadráticas. Esporófito único, cápsula ereta a subereta, pescoço não ou pouco diferenciado, peristômio duplo.

Material examinado: Minas Gerais, Santana do Riacho, perto do Riacho Lagoa Comprida, O. Yano \& Wanderley 10619 (SP220314); Cachoeira Farofa, O. Yano \& Wanderley 10676, 10677, 10681 (SP220371; SP220372; SP220376); Córrego Inhame, O. Yano \& Wanderley 10910 (SP220603); Retiro, O. Yano \& Wanderley 10920 (SP220613); Dias Neto 262 (SP419841).

Ocorre nos estados do BA, DF, GO, MS, PE, PI, RJ, RN, RR, RS e SP. Na Serra do Cipó, cresce em tronco vivo, termiteiro e barranco. Esta espécie ocorre freqüentemente sobre termiteiro e rochas em áreas expostas. Os filídios quando secos ficam caracteristicamente espiralados. Esta é a primeira ocorrência para Minas Gerais.

3.4. Gemmabryum subapiculatum (Hampe) J.R. Spence \& H.P. Ramsay, Phytologia 87(2): 68. 2005.

Fig. 4 n-s

Gametófitos medianos, verde-claros a verdeescuros. Filídios lanceolados, côncavos, igualmente dispostos em todo o caulídio, quando secos eretos a imbricados, pequenos (usualmente menor do que 5 $\mathrm{mm}$ compr.), bordeados por células muito longas e distintas, margem na porção mediana superior 


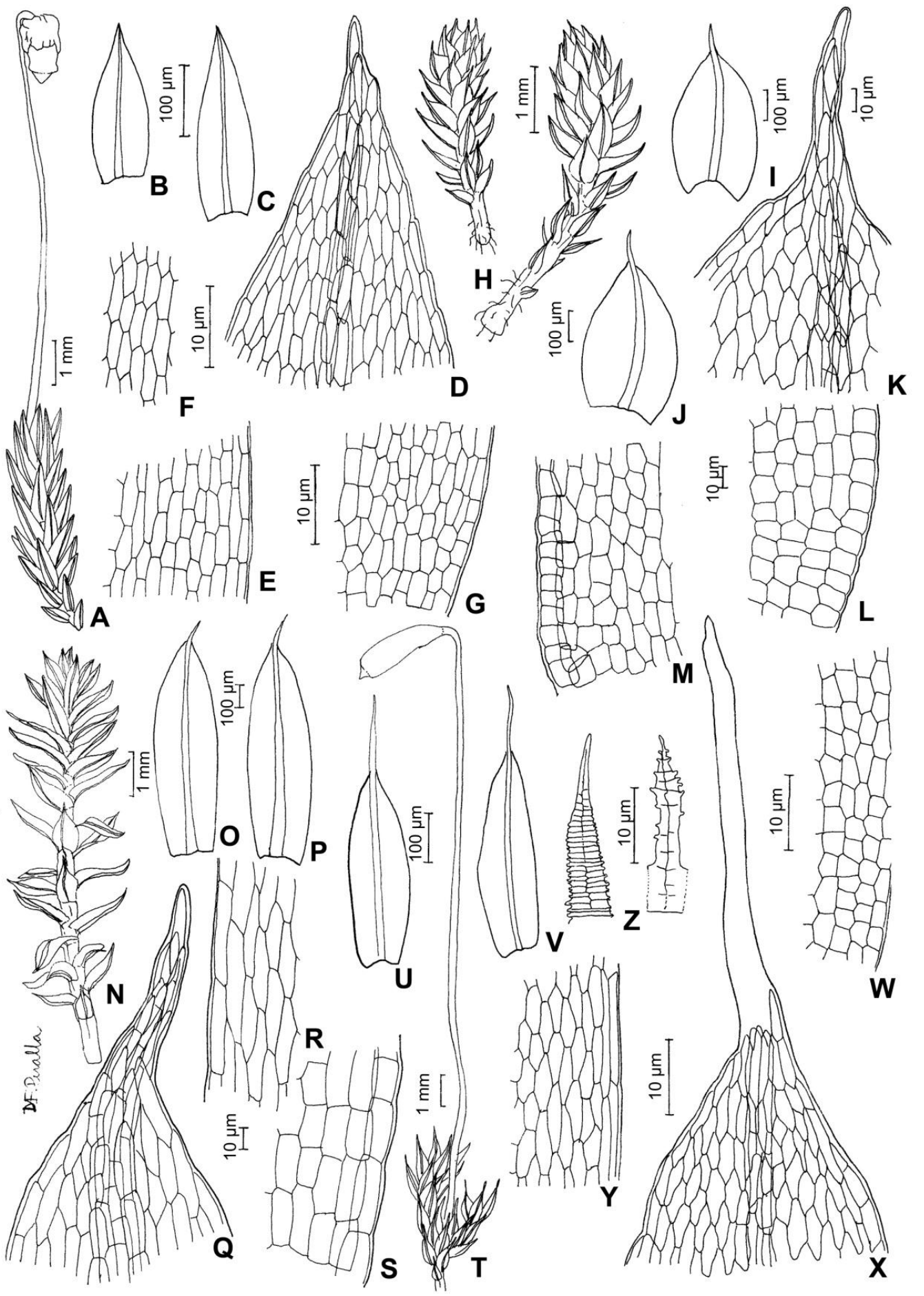

Fig. 4. Gemmabryum coronatum (Schwägr.) J.R. Spence \& H.P. Ramsay. A. aspecto do gametófito. B-C. filídios. D. células do ápice do filídios. E. células da margem do filídio. F. células da lâmina do filídio. G. células da base do filídio. Gemmabryum exile (Dozy \& Molk.) J.R. Spence \& H.P. Ramsay. H. aspecto do gametófito. I-J. filídios. K. células do ápice do filídio. L. células da margem do filídio. M. células da base do filídio. Gemmabryum subapiculatum (Hampe) J.R. Spence \& H.P. Ramsay. N. aspecto do gametófito. O-P. filídios. Q. células do ápice do filídio. R. células da margem do filídio. S. células da base do filídio. Ptychostomum capillare (Hedw.) Holyoak \& N. Pedersen. T. aspecto do gametófito. U-V. filídios. X. células do ápice do filídio. Y. células da margem do filídio. Z. dentes do peristômio. W. células da base do filídio (A-G. O. Yano \& Wanderley 10908; H-M. O. Yano \& Wanderley 10619; N-S. O. Yano \& Wanderley 10702; T-W. O. Yano 491). 
denticulada, porção mediana inferior plana, ápice do filídio agudo. Costa curto-excurrente, células da região mediana longo-hexagonais, células da base retangulares. Esporófito único, cápsula pêndula a horizontal, pescoço não ou pouco diferenciado, peristômio duplo.

Material examinado: Minas Gerais, Cardeal Mota, APA Morro da Pedreira, Pirani et al. 5556 (SP389347, SPF37045); Conceição do Mato Dentro, Oliveira Filho 6 (SP90869); Santana do Riacho, Morro Carambinha, O. Yano \& Wanderley 10702 (SP220397).

Ocorre nos estados do AM, BA, DF, GO, MA, MT, PA, PR, RJ, RR, RS e SP. Na Serra do Cipó, cresce em rocha e termiteiro.

\section{Ptychostomum Hornsch.}

Gametófitos acrocárpicos, pequenos, delicados, formando tufos. Caulídios primários eretos, tomentosos, ramos secundários ascendentes. Filídios ligulados ou lanceolados, côncavos, espiralados, planos quando secos. Costa única, 1/2 ou 3/4 compr. do filídio, percurrente, estreita, ápice do filídio agudo, margem do filídio plana, inteira, bordeada, células da lâmina longo-hexagonais, pouco alongadas, lisas, parede celular delgada, reta, células da base do filídio mais claras, alongadas porém não infladas. Seta longa, reta. Cápsula pêndula, assimétrica, urna piriforme ou ovóide, rômbica, superfície lisa quando seca, ânulo presente. Opérculo cônico. Peristômio duplo. Caliptra glabra.

4.1. Ptychostomum capillare (Hedw.) Holyoak \& N. Pedersen, J. Bryol. 29: 119. 2007.

Fig. $4 \mathrm{~T}-\mathrm{Z}$

Gametófitos medianos, verde-claros a verdeescuros. Filídios oblongo-lanceolados, planos, igualmente dispostos em todo o caulídio, quando secos espiralados, pequenos (usualmente menor do que $5 \mathrm{~mm}$ compr.), bordeados por células muito longas e distintas, margem na porção mediana superior inteira, porção mediana inferior encurvada, ápice do filídio agudo ou obtuso. Costa curtoexcurrente, células da região mediana fusiformes ou longo-hexagonais, células da base retangulares. Esporófito único, cápsula pêndula a horizontal, pescoço não ou pouco diferenciado, peristômio duplo.

Material examinado: Minas Gerais, Conceição do Mato Dentro, O. Yano 491 (SP135458); O. Yano 492 (SP135459).

Ocorre nos estados da BA, DF, ES, CE, GO, MG, MS, MT, PA, PB, PE, PI, RJ, PR, RO, RN, RS, SC e SP. Na Serra do Cipó, cresce em rocha e termiteiro.

\section{Rosulabryum J.R. Spence}

Gametófitos acrocárpicos, medianos ou robustos, formando tufos. Caulídios primários eretos, tomentosos, ramos secundários ascendentes. Filídios ligulados ou lanceolados ou ovados, planos. Em fascículos (rosulados) ou espiralados, quando secos crispados ou planos. Costa única, $1 / 2$ ou $3 / 4$ compr. do filídio, percurrente ou excurrente, estreita, ápice do filídio apiculado, pilífero, acuminado ou agudo, margem do filídio plana, inteira, denticulada ou denteada, bordeada, células da lâmina longohexagonais, pouco alongadas, lisas, parede celular delgada, reta, células da base do filídio mais claras, alongadas porém não infladas. Seta longa, curvada. Cápsula exserta, pêndulas, assimétrica, urna piriforme ou ovóide, rômbica, superfície lisa quando seca, ânulo presente. Opérculo cônico. Peristômio duplo. Caliptra glabra.

A coloração verde-escuro e em algumas espécies avermelhada, além da disposição dos filídios em verticilos na maioria das espécies são característicos deste gênero.

1. Filídios avermelhados; medianos (usualmente maior que $8 \mathrm{~mm}$ compr.); gametófitos robustos ................. 5.3. R. huillense

1'. Filídios verde-claros a verde-escuros; pequenos (usualmente menor do que $5 \mathrm{~mm}$ compr.); gametófitos medianos.

2. Porção mediana inferior encurvada; ápice do filídio obtuso; dispostos em rosetas; costa curtoexcurrente.

2'. Porção mediana inferior plana; ápice do filídio agudo; igualmente dispostos em todo o caulídio; costa percurrente 


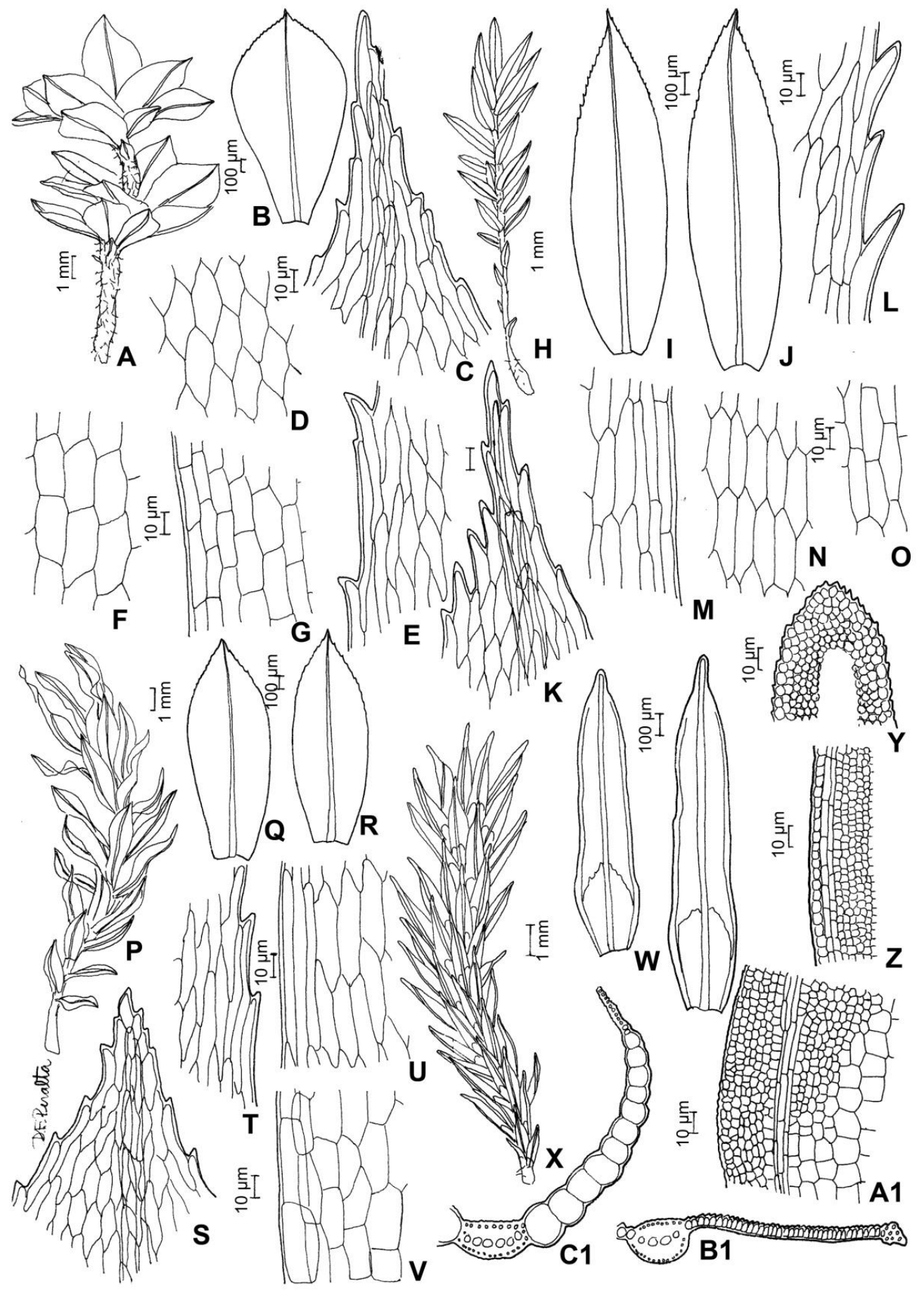

Fig. 5. Rosulabryum billardierei (Schwägr.) J.R. Spence. A. aspecto do gametófito. B. filídio. C. células do ápice do filídio. D. células da lâmina do filídio. E. células da margem do filídio. F. células da lâmina basal do filídio. G. células da base do filídio. Rosulabryum densifolium (Brid.) Ochyra. H. aspecto do gametófito. I-J. filídios. K. células do ápice do filídio. L. células da margem do filídio. M. células da base do filídio. N. células da lâmina do filídio. O. células da lâmina basal do filídio. Rosulabryum huillense (Welw. \& Duby) Ochyra. P. aspecto do gametófito. Q-R. filídios. S. células do ápice do filídio. T. células da margem do filídio. U. células da margem basal do filídio. V. células da base do filídio. Calymperes erosum Müll. Hal. X. aspecto do gametófito. W. filídios. Y. células do ápice do filídio. Z. células da margem do filídio. A1. células do ombro dos filídios. B1. secção transversal da lâmina do filídio. C1. secção transversal da base do filídio (A-G. Pirani et al. 5637; H-O. O. Yano \& Wanderley 10794; P-V. O. Yano \& Wanderley 10645; X-C1. Pirani et al. 10382). 
5.1. Rosulabryum billardierei (Schwägr.) J.R. Spence, Bryologist 99(2): 223. 1996.

Fig. 5 A-G

Gametófitos medianos, verde-claros a verdeescuros. Filídios oblongo-lanceolados ou obovados, planos, dispostos em rosetas, quando secos eretos a imbricados, pequenos (usualmente menor do que 5 $\mathrm{mm}$ compr.), bordeados por células muito longas e distintas, margem na porção mediana superior denteada, porção mediana inferior encurvada, ápice do filídio obtuso. Costa curto-excurrente, células da região mediana longo-hexagonais, células da base retangulares. Esporófito único, cápsula pêndula a horizontal, pescoço não ou pouco diferenciado, peristômio duplo.

Material examinado: Minas Gerais, Congonhas do Norte, Serra Talhada, Pirani et al. 5637 (SP389355; SPF); Santana do Riacho, Câmara 1875 p.p. (SP419633).

Associada a Trachyphyllum dusenii (Müll. Hal. ex Broth.) Broth. Ocorre nos estados do AM, BA, CE, DF, ES, GO, MA, MG, MS, MT, PA, RJ, RO, SC e SP. $\mathrm{Na}$ Serra do Cipó, cresce em rocha.

5.2. Rosulabryum densifolium (Brid.) Ochyra in Ochyra, Zarnowic \& Bednarek-Ochyra, Biodiv. Poland. 3: 162. 2003.

Fig. $5 \mathrm{H}-\mathrm{O}$

Gametófitos medianos, verde-claros a verdeescuros. Filídios lanceolados, planos, igualmente dispostos em todo o caulídio, quando secos eretos a imbricados, pequenos (usualmente menor do que $5 \mathrm{~mm}$ compr.), bordeados por células muito longas e distintas, margem na porção mediana superior denteada, porção mediana inferior plana, ápice do filídio agudo. Costa percurrente, células da região mediana longohexagonais, células da base quadráticas ou retangulares. Esporófito em agrupamentos, cápsula pêndula a horizontal, peristômio duplo.

Material examinado: Minas Gerais, Santana do Riacho, Serra da Bandeirinha, O. Yano \& Wanderley 10794 (SP220487); idem, O. Yano \& Wanderley 10796 (SP220489).

Ocorre nos estados da AL, BA, DF, ES, MG, PE, RJ, PR, RS, SC, SP e TO. Na Serra do Cipó, cresce em solo e tronco vivo. Esta é uma das poucas espécies do gênero que não apresentam os filídios rosulados (em verticilos), é facilmente identificada pelo formato longo-lanceolado dos filídios e a margem com dentes grandes.

5.3. Rosulabryum huillense (Welw. \& Duby) Ochyra in Ochyra, Zarnowic \& Bednarek-Ochyra, Biodiv. Poland. 3: 162. 2003.

Fig. 5 P-V

Gametófitos robustos, avermelhados. Filídios obovados, planos, dispostos em rosetas, quando secos eretos a imbricados, medianos (usualmente maior que $8 \mathrm{~mm}$ compr.), bordeados por células muito longas e distintas, margem na porção mediana superior denteada, porção mediana inferior encurvada, ápice do filídio obtuso. Costa percurrente ou curtoexcurrente, células da região mediana fusiformes ou longo-hexagonais, células da base retangulares. Esporófito em agrupamentos, cápsula pêndula a horizontal, pescoço mesma largura da urna e enrugado, peristômio duplo.

Material examinado: Minas Gerais, Santana do Riacho, Cachoeira Farofa, O. Yano \& Wanderley 10645, 10646 p.p. (SP220340; SP220341).

Associada a Callicostella pallida (Hornsch.) Ångstr. e Philonotis sphaerocarpa (Hedw.) Brid. Ocorre nos estados do BA, GO, MT, PR, RJ, RS, SC e SP. Na Serra do Cipó, cresce em rocha. Entre as espécies deste gênero encontradas na Serra do Cipó esta é a única que apresentou uma coloração avermelhada forte.

\section{Calymperaceae}

Gametófitos acrocárpicos, pequenos e delicados ou medianos, formando tufos. Caulídios primários eretos. Filídios ligulados ou lanceolado, planos ou canaliculados, quando secos crispados, base vaginante. Costa única, percurrente, estreita, secção transversal camada de estereídios distinta, ápice do filídio apiculado, obtuso ou agudo, margens involuta ou plana, inteira, denticulada ou denteada, não bordeada ou bordeada. Células da lâmina circulares, ou quadrático irregulares, isodiamétricas, lisas ou papilosas, parede celular espessada, reta, base do filídio (região alar) grande porção de células muito infladas e translúcidas (cancelinas). Reprodução vegetativa por gemas no ápice dos filídios ou nervura da lâmina dos filídios. Dióicos. Seta curta ou longa, reta, marrom-dourada, lisa. Cápsula exserta ou imersa, ereta, simétrica, urna subcilíndrica, rômbica. Peristômio ausente ou único. Caliptra grande e cobrindo a cápsula após o desenvolvimento, glabra, plicada.

É uma família bastante comum no Brasil, caracterizada principalmente pela costa simples bastante pronunciada e as células da base claras e freqüentemente infladas contrastando com as células da lâmina pequenas e na maioria das vezes papilosas. Ocorre principalmente como corticícola, terrestre e rupícola. No Brasil ocorrem dois gêneros e 42 espécies; na Serra do Cipó ocorrem dois gêneros e oito espécies. Destaca-se Syrrhopodon tortilis, que apresenta distribuição nas regiões montanhosas do Brasil.

Bibliografia básica - Gradstein et al. (2001); Reese (2003); Sharp et al. (1994); Yano \& Peralta (2009). 
Flora da Serra do Cipó, Minas Gerais: Briófitas (Anthocerotophyta, Bryophyta e Marchantiophyta)

Chave para os gêneros

1. Filídios com teníola intramarginal

2. Syrrhopodon

1'. Filídios sem teníola intramarginal .

1. Calymperes

\section{Calymperes Sw.}

Gametófitos acrocárpicos, medianos, formando tufos. Caulídios primários eretos, poucos rizóides, ramos secundários ascendentes. Filídios ligulados ou lanceolados, planos ou canaliculados, espiralados, quando secos crispados, base do filídio formando bainha vaginante. Costa única, percurrente, estreita, secção transversal com camada de estereídios distinta, ápice do filídio apiculado ou obtuso ou agudo, margem do filídio involuta, encurvada ou plana, margem inteira, denticulada ou denteada, não bordeada, células da lâmina circulares ou quadráticoirregulares, isodiamétricas, lisas ou papilosas, parede celular espessada, reta, células da base do filídio grande porção de células muito infladas e translúcidas (cancelinas), teníola intramarginal presente. Reprodução vegetativa por gemas, no ápice dos filídios. Seta longa, reta. Cápsula exserta, ereta, simétrica, urna sub-cilíndrica, rômbica, superfície lisa quando seca, Opérculo rostrado. Peristômio ausente. Caliptra grande e cobrindo a cápsula após o desenvolvimento, glabra, plicada.

1.1. Calymperes erosum Müll. Hal., Linnaea 21: 182. 1848.

Fig. $5 \mathrm{X}-\mathrm{C} 1$

Gametófitos medianos. Filídios lanceolados, ombros pouco ou não diferenciados, quando secos espalhados, não bordeados, margem da porção mediana superior do filídio uniestratificada, margem na porção mediana superior denteada, ombros denticulados, base inteira, composta por células iguais as interiores, teníola intramarginal presente, ápice dos filídios agudo, costa percurrente, dorsalmente lisa, células papilosas, inserção da cancelina oblíqua. Propágulos sobre o ápice da costa dos filídios.
Material examinado: Minas Gerais, Santana do Riacho, Pirani et al. 10382 (SP230728).

Ocorre nos estados de AC, AM, AP, BA, CE, ES, GO, MG, MT, PA, PB, PE, RJ, RO, RR, SP e TO. $\mathrm{Na}$ Serra do Cipó, cresce em tronco vivo. É uma espécie caracteristicamente corticícola e facilmente identificada pela presença da teníola.

\section{Syrrhopodon Schwägr.}

Gametófitos acrocárpicos, medianos, formando tufos. Caulídios primários eretos, poucos rizóides, ramos secundários ascendentes. Filídios ligulados ou lanceolados, planos ou canaliculados, espiralados, quando secos crispados, base do filídio formando bainha vaginante. Costa única, percurrente, estreita, secção transversal com camada de estereídios distinta, ápice do filídio apiculado, obtuso ou agudo, margem do filídio involuta, encurvada ou plana, margem inteira, denticulada ou denteada, não bordeada ou bordeada (ca. 10-15:1 compr.), células da lâmina circulares ou quadrático-irregulares, isodiamétricas, lisas ou papilosas, parede celular espessada, reta, células da base do filídio grande porção de células muito infladas e translúcidas (cancelinas), teníola intramarginal ausente. Reprodução vegetativa por gemas, no ápice dos filídios ou nervura da lâmina dos filídios. Seta curta ou longa, reta. Cápsula exserta ou imersa, ereta, simétrica, urna subcilíndrica, rômbica, superfície lisa quando seca, Opérculo rostrado. Peristômio simples. Caliptra grande e cobrindo a cápsula após 0 desenvolvimento, glabra, plicada.

\section{Chave para as espécies}

1. Propágulos sempre presentes, sobre a costa ou ápice dos filídios.

2. Propágulos sobre a costa dos filídios ......................................................................................... 2.5. parasiticus

2'. Propágulos sobre o ápice da costa dos filídios ............................................................................ 2.6. S. prolifer

1'. Propágulos ausentes.

3. Margem na porção mediana superior inteira

3'. Margem na porção mediana superior denteada a ciliada.

4. Margem na porção mediana superior denteada.

5. Margem composta por células iguais as interiores; costa dorsalmente denteada; células lisas .... 2.3. S. incompletus

5'. Margem composta por várias camadas de células estreitas; costa dorsalmente lisa; células papilosas

4'. Margem na porção mediana superior ciliada.

6. Margem composta por células iguais as interiores; ombros pouco ou não diferenciados;

gametófitos pequenos ............................................................................................ 2.2. S. gaudichaudii

6'. Margem composta por várias camadas de células estreitas; ombros diferenciados; gametófitos medianos 
2.1. Syrrhopodon gardneri (Hook.) Schwägr., Spec. Musc. Frond. Suppl. 2(1): 110. 1824.

Fig. 6 A-H

Gametófitos medianos. Filídios lanceolados ou ligulados, ombros diferenciados, quando secos espiralados, não bordeados, margem da porção mediana superior do filídio multiestratificada, margem na porção mediana superior denteada, ombros denticulados, base inteira, composta por várias camadas de células estreitas, teníola intramarginal ausente, ápice dos filídios agudo, costa percurrente, dorsalmente lisa, células papilosas, inserção da cancelina oblíqua. Propágulos ausentes.

Material examinado: Minas Gerais, Santana do Riacho, Cachoeira Farofa, O. Yano \& Wanderley 10679 (SP220374).

Ocorre nos estados do AM, BA, GO, MG, MT e RJ. Na Serra do Cipó, cresce em rocha. Esta espécie é caracterizada pelos dentes na margem do filídio e hábito mediano.

2.2. Syrrhopodon gaudichaudii Mont., Ann. Sci. Nat. Bot. sér. 2, 2 : 376. 1834.

Fig. 6 I-P

Gametófitos pequenos. Filídios linearlanceolados ou lanceolados, ombros pouco ou não diferenciados, quando secos espiralados, bordeados por células longas em toda a extensão do filídio, margem da porção mediana superior do filídio uniestratificada, margem na porção mediana superior ciliada, ombros denticulados, base inteira, composta por células iguais as interiores, teníola intramarginal ausente, ápice dos filídios agudo, costa percurrente, dorsalmente denteada, células papilosas, inserção da cancelina rômbica. Propágulos ausentes.

Material examinado: Minas Gerais, Conceição do Mato Dentro, O. Yano 495 (SP135462); idem, O. Yano 517 (SP135475); Santana do Riacho, Pirani et al. 10377 p.p. (SP230733); Cachoeira Farofa, O. Yano \& Wanderley 10671 (SP220366); O. Yano \& Wanderley 10816 (SP220509); Câmara et al. 2102a (SP419711); Dias Neto 163 (SP419784); Dias Neto 230 (SP419825); Dias Neto 235, 241, 243 (SP419828; SP419081; SP419830).

Associada a Taxilejeunea pterigonia (Lehm. \& Lindenb.) Schiffn. Ocorre nos estados do AM, BA, DF ES, GO, MA, MG, MT, PA, PE, PR, RJ, RS, SC, SE, SP e TO. Na Serra do Cipó, cresce em solo, rocha e tronco vivo. A porção distal dos filídios desta espécie quando secos estão sempre crispados e escuros, contrastando com as células da canceliinas grandes $e$ claras.

2.3. Syrrhopodon incompletus Schwägr., Spec. Musc. Frond. Suppl. 2(1): 119. 1824.

Fig. $6 \mathrm{Q}-\mathrm{Y}$

Gametófitos medianos. Filídios lanceolados, ombros diferenciados, quando secos espalhados, não bordeados, margem da porção mediana superior do filídio multiestratificada, margem na porção mediana superior denteada, ombros denticulados, base inteira, composta por células iguais as interiores, teníola intramarginal ausente, ápice dos filídios agudo, costa percurrente, dorsalmente denteada, células lisas. Inserção da cancelina oblíqua. Propágulos ausentes.

Material examinado: Minas Gerais, Santana do Riacho, Dias Neto 125 (SP419758).

Ocorre nos estados do AC, AL, AM, AP, BA, GO, MG, MS, MT, PA, PE, PR, RJ, RR, SC e SP. Na Serra do Cipó, cresce em tronco vivo. Esta é a espécie que apresenta 0 maior hábito dentre as espécies ocorrentes na Serra do Cipó, comumente ela cobre grandes porções do tronco de árvores vivas.

2.4. Syrrhopodon ligulatus Mont., Syll. Gen. Spec. Crypt.: 47. 1856.

Fig. 6 Z-F1

Gametófitos pequenos. Filídios ligulados, ombros pouco ou não diferenciados, quando secos crispados, bordeados por células longas em toda a extensão do filídio ou bordo incompleto, às vezes atingindo pouco acima dos ombros, margem da porção mediana superior do filídio uniestratificada, margem inteira, composta por células iguais as interiores, teníola intramarginal ausente, ápice dos filídios obtuso, costa percurrente, dorsalmente lisa, células papilosas, inserção da cancelina rômbica. Propágulos ausentes.

Material examinado: Minas Gerais, Santana do Riacho, Câmara 1869, 1886 (SP419631; SP419637); Dias Neto 120, 120a (SP419754; SP419755).

Ocorre nos estados de AL, AM, AP, BA, CE, DF, ES, GO, MG, MS, MT, PA, PE, RJ, RO, RR e SP. $\mathrm{Na}$ Serra do Cipó, cresce em tronco vivo. Esta espécie é a que apresenta o menor hábito das espécies encontradas, é facilmente identificada pelo formato do filídio ligulado com o ápice truncado a apiculado.

2.5. Syrrhopodon parasiticus (Brid.) Besch., Ann. Sci. Nat. Bot. sér. 8, 1: 298. 1895.

Fig. 7 A-H

Gametófitos medianos. Filídios lanceolados, ombros pouco ou não diferenciados, quando secos espalhados, bordeados por células longas em toda a extensão do filídio ou bordo incompleto, às vezes atingindo acima dos ombros, margem da porção mediana superior do filídio uniestratificada, margem inteira, composta por células iguais as interiores, teníola intramarginal ausente, ápice dos filídios agudo, costa percurrente, dorsalmente lisa, células papilosas, inserção da cancelina oblíqua. Propágulos sobre a costa dos filídios. 


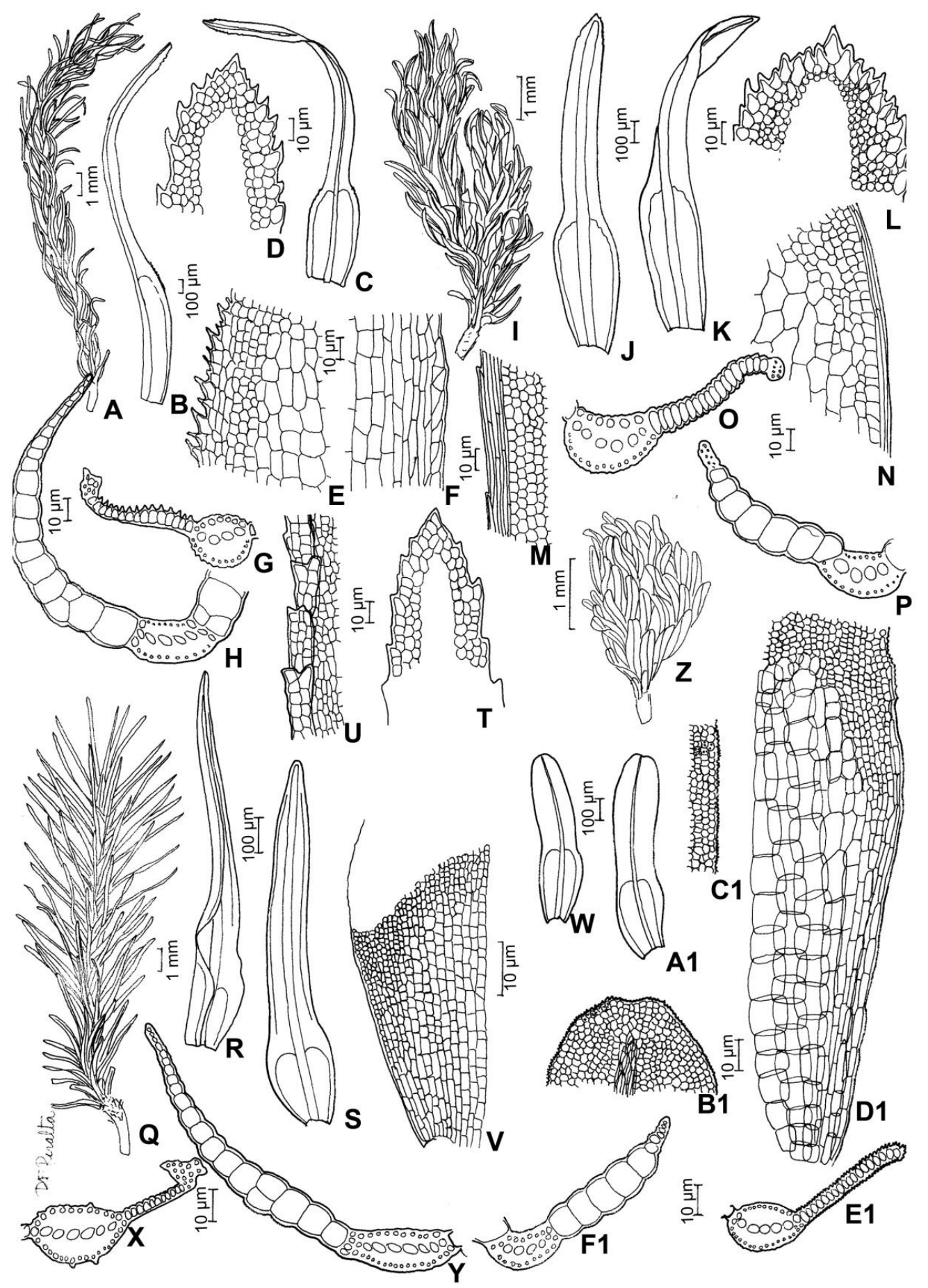

Fig. 6. Syrrhopodon gardneri (Hook.) Schwägr. A. aspecto do gametófito. B-C. filídios. D. células do ápice do filídio. E. células do ombro do filídio. F. células da margem do filídio. G. secção transversal da lâmina do filídio. H. secção transversal da base do filídio. Syrrhopodon gaudichaudii Mont. I. aspecto do gametófito. J-K. filídios. L. células do ápice do filídio. M. células da margem do filídio. N. células do ombro do filídio. O. secção transversal da lâmina do filídio. P. secção transversal da base do filídio. Syrrhopodon incompletus Schwägr. Q. aspecto do gametófito. R-S. filídios. T. células do ápice do filídio. U. células da margem do filídio. V. células da margem basal do filídio. X. secção transversal da lâmina do filídio. Y. secção transversal da base do filídio. Syrrhopodon ligulatus Mont. Z. aspecto do gametófito. W-A1. filídios. B1. células do ápice do filídio. C1. células da margem do filídio. D1. células da base do filídio. E1. secção transversal da lâmina do filídio. F1. secção transversal da base do filídio (A-H. O. Yano \& Wanderley 10679; I-P. O. Yano 495; Q-Y. Dias Neto 125; Z-F1. Câmara 1869). 
Material examinado: Minas Gerais, Santana do Riacho, Morro Carambinha, O. Yano \& Wanderley 10701 (SP220396); Dias Neto 228 (SP419824).

Ocorre nos estados do AC, AL, AM, BA, CE, DF, ES, GO, MG, MS, MT, PA, PE, PR, RJ, RO, RR, RS, SC, SP e TO. Na Serra do Cipó, cresce em tronco vivo. Esta espécie é comumente encontrada em pequenos tufos sobre o tronco e sempre com muitos propágulos sobre a porção ventral da costa nos filídios.

2.6. Syrrhopodon prolifer Schwägr., Spec. Musc. Frond. Suppl. 2(2): 99. 1827.

Fig. 7 I-P

Gametófitos pequenos ou medianos. Filídios linear-lanceolados, ombros pouco ou não diferenciados, quando secos crispados, bordeados por células longas em toda a extensão do filídio ou bordo incompleto, às vezes atingindo acima dos ombros, margem da porção mediana superior do filídio uniestratificada, margem na porção mediana superior ciliada ou inteira, ombros inteira, base inteira, composta por várias camadas de células estreitas, teníola intramarginal ausente, ápice dos filídios agudo, costa percurrente ou curto-excurrente, dorsalmente denteada, células papilosas, inserção da cancelina rômbica. Propágulos sobre o ápice da costa dos filídios.

Material examinado: Minas Gerais, Conceição do Mato Dentro, Vital 7585 (SP136555); Santana do Riacho, Pirani et al. 10382 (SP86344, SPF); Serra da Bandeirinha, $O$ Yano \& Wanderley 10818 p.p. (SP220511); O. Yano \& Wanderley 10930 (SP220623); Dias Neto 169 (SP419788).

Associada a Lejeunea flava (Sw.) Nees. Ocorre nos estados do AL, AM, AP, BA, CE, DF, ES, GO, MG, MT, PA, PE, PI, PR, RJ, RO, RS, SC, SE, SP e TO. Na Serra do Cipó, cresce em rocha e solo. Esta é a espécie que apresenta os filídios mais longos e estreitos deste gênero. Apesar de possuir as células com papilas os gametófitos são claros e brilhantes quando vistos sob lupa.

2.7. Syrrhopodon tortilis Hampe, Vidensk. Meddel. Dansk Naturhist. For. Kjøbenhavn. ser. 3, 4: 38. 1872.

Fig. $7 \mathrm{Q-X}$

Gametófitos medianos. Filídios lanceolados, ombros diferenciados, quando secos espalhados, bordeados por células longas em toda a extensão do filídio, margem da porção mediana superior do filídio uniestratificada, margem na porção mediana superior ciliada, ombros denticulados, base inteira, composta por várias camadas de células estreitas, teníola intramarginal ausente, ápice dos filídios agudo, costa percurrente ou curto-excurrente, dorsalmente denteada, células papilosas, inserção da cancelina rômbica. Propágulos ausentes.

Material examinado: Minas Gerais, Santana do Riacho, Cachoeira Farofa, O. Yano \& Wanderley 10640 p.p. (SP220335); Câmara 1973 (SP419681); Câmara et al. 2092, 2096 (SP419707; SP419709); Dias Neto 87 (SP419730); Dias Neto 134, 139 (SP419765; SP419769); Dias Neto 198 (SP419808).

Associada a Zoopsidella integrifolia (Spruce) Steph. Ocorre nos estados do RJ, SC e SP. Na Serra do Cipó, cresce em rocha e solo próximo de cachoeira. Esta espécie é característica de locais próximos a cachoeira, comumente encontrada em pequenos bancos de areia formados durante o período chuvoso.

\section{Dicranaceae}

Gametófitos acrocárpicos, pequenos e delicados ou medianos, formando tufos. Caulídios primários eretos, tomentosos, ramos secundários ascendentes. Filídios lanceolados, planos ou canaliculados, em fascículos ou espiralados, base do filídio auriculada. Costa única, percurrente ou excurrente, larga (2/3 a 3/4 da largura do filídio), secção transversal camada de estereídios distinta, lamelas dorsais presentes ou não, ápice do filídio ou acuminado, margens plana, inteira ou denticulada, não bordeada ou bordeada. Células da lâmina retangulares ou quadrático irregulares, pouco alongadas ou mais ou menos isodiamétricas, lisas ou papilosas, parede celular espessada, porosa ou reta, região alar 1-10 fileira de células infladas e coloridas de marrom a laranja. Dióicos, monóicos ou autóicos. Seta presente, longa, reta ou flexuosa, marrom-dourada, torcida ou lisa. Cápsula exserta, ereta, assimétrica ou simétrica, urna ovóide ou subcilíndrica, rômbica. Peristômio único. Caliptra glabra, não plicada.

É uma família amplamente distribuída no Brasil, caracterizada principalmente pela costa larga e conspícua e as células alares infladas e coloridas. Ocorre nos mais variados substratos e está sempre associada a locais ventilados e expostos diretamente. Para a identificação das espécies são necessários cortes transversais do filídio na região da costa, o arranjo dos leucocistos e estereídios são utilizados para separação de gêneros e espécies. No Brasil ocorrem 20 gêneros e 115 espécies; na Serra do Cipó ocorrem cinco gêneros e 21 espécies.

Bibliografia básica - Frahm (1991); Gradstein et al. (2001); Sharp et al. (1994); Yano \& Peralta (2009). 


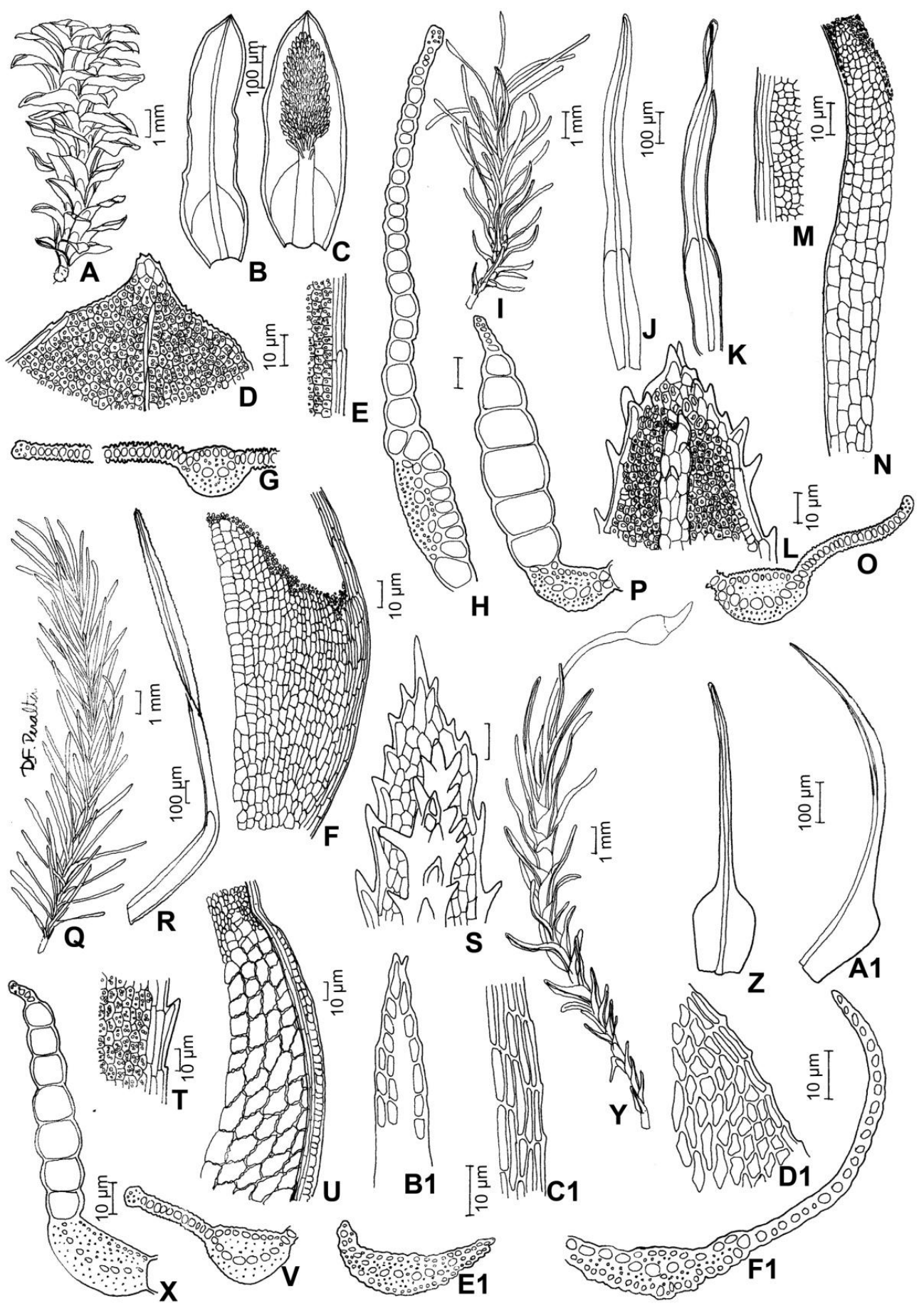

Fig. 7. Syrrhopodon parasiticus (Brid.) Besch. A. aspecto do gametófito. B-C. filídios. D. células do ápice do filídio. E. células da margem do filídio. F. células da base do filídio. G. secção transversal da lâmina do filídio. $\mathrm{H}$. secção transversal da base do filídio. Syrrhopodon prolifer Schwägr. I. aspecto do gametófito. J-K. filídios. L. células do ápice do filídio. M. células da margem do filídio. N. células da base do filídio. O. secção transversal da lâmina do filídio. P. secção transversal da base do filídio. Syrrhopodon tortilis Hampe. Q. aspecto do gametófito. R. filídio. S. células do ápice do filídio. T. células da margem do filídio. U. células do ombro do filídio. V. secção transversal da lâmina do filídio. X. secção transversal da base do filídio. Anisothecium vaginatum (Hook.) Mitt. Y. aspecto do gametófito. Z-A1. filídios. B1. células do ápice do filídio. C1. células da margem do filídio. D1. células da margem do filídio. E1. secção transversal da lâmina do filídio. F1. secção transversal da base do filídio (A-H. $O$. Yano \& Wanderley 10701; I-P. Vital 7585; Q-X. O. Yano \& Wanderley 10640 p.p.; Y-F1. Vital 1257 ). 
1. Costa subpercurrente.

2. Filídios imbricados; base amplamente vaginante; células da região mediana quadráticas; porosas 4. Holomitrium

2'. Filídios espalhados; base não vaginante; células da região mediana retangulares; não porosas 3. Dicranella

1'. Costa percurrente a curto-excurrente.
3. Costa curto-excurrente
2. Campylopus
3'. Costa percurrente.
4. Paredes das células da base delgadas e translúcidas; lisas; células da margem iguais as interiores; células alares não diferenciadas Anisothecium
4'. Paredes das células da base espessadas, concolores; papilosas; células da margem em várias camadas de células longas; células alares diferenciadas (infladas e coloridas) 5. Leucoloma

\section{Anisothecium Mitt.}

Gametófitos acrocárpicos, pequenos, delicados, formando tufos. Caulídios eretos, tomentosos. Filídios lanceolados, planos ou canaliculados, espiralados, planos quando secos, base do filídio simples. Costa única, percurrente, estreita (1/4 a $1 / 5$ da largura do filídio), secção transversal com camada de estereídios distinta, lâmina do filídio sem lamelas, ápice do filídio acuminado, margem do filídio plana, inteira ou denticulada, não bordeada ou bordeada (ca. 10-15:1 compr.), células da lâmina retangulares, quadráticas ou irregulares, pouco alongadas ou isodiamétricas, lisas, parede celular delgada, reta, células da base pouco diferenciadas. Reprodução vegetativa ausente. Seta longa, reta ou flexuosa, lisa. Cápsula ereta, simétrica, urna ovóide ou sub-cilíndrica, rômbica, superfície quando seca estriada. Opérculo rostrado. Peristômio simples. Caliptra glabra.

Chave para as espécies

1. Filídios imbricados; base amplamente vaginante

1.1. A. vaginatum

1 '. Filídios espalhados; base não vaginante

1.2. A. varium

1.1. Anisothecium vaginatum (Hook.) Mitt., J. Linn. Soc. Bot. 12: 39. 1869.

Fig. 7 Y-F1

Gametófitos pequenos. Filídios lanceolados, dispostos igualmente em todo o caulídio, imbricados, células da região mediana quadráticas, lisas, células da margem iguais as interiores, base amplamente vaginante, células da base retangulares (alongadas), paredes das células da base delgada e translúcida, não porosa, células alares não diferenciadas, ápice do filídio acuminado, costa percurrente. Filídios periqueciais iguais aos demais. Seta ereta, simétrica.

Material examinado: Minas Gerais, Conceição do Mato Dentro, Vital 1257 (SP88564)

Ocorre nos estados do PR e RS. Na Serra do Cipó, cresce em barranco. A presença nos filídios de uma bainha amplamente vaginante que envolve o caulídio é uma característica marcante desta espécie e facilmente visualizada.

1.2. Anisothecium varium (Hedw.) Mitt., J. Linn Soc. Bot. 12: 40.1869.

Fig. $8 \mathrm{~A}-\mathrm{H}$

Gametófitos pequenos. Filídios lanceolados, dispostos igualmente em todo o caulídio, espalhados, células da região mediana retangulares, lisas, células da margem iguais as interiores, base não vaginante, células da base retangulares (alongadas), paredes das células da base delgadas e translúcidas, não porosas, células alares não diferenciadas, ápice do filídio acuminado, costa percurrente. Filídios periqueciais iguais aos demais. Seta ereta, assimétrica.

Material examinado: Minas Gerais, Conceição do Mato Dentro, Vital 1242 (SP88537).

Ocorre nos estados do CE, GO, MT e SP. Na Serra do Cipó, cresce em barranco. Esta espécie é difícil de diferenciar de Dicranella hilariana quando estão sem esporófito. Quanto este está presente a cápsula inclinada de $A$. varium é característica.

\section{Campylopus Brid.}

Gametófitos acrocárpicos, medianos, formando tufos. Caulídios primários eretos, tomentosos, ramos secundários ascendentes. Filídios lanceolados, planos ou canaliculados, em fascículos (rosulados) ou espiralados, planos quando secos, base do filídio auriculada ou não. Costa única, percurrente ou excurrente, larga (2/3 a 3/4 da largura do filídio), secção transversal com camada de estereídios distinta, lâmina do filídio com lamelas dorsais ou sem 


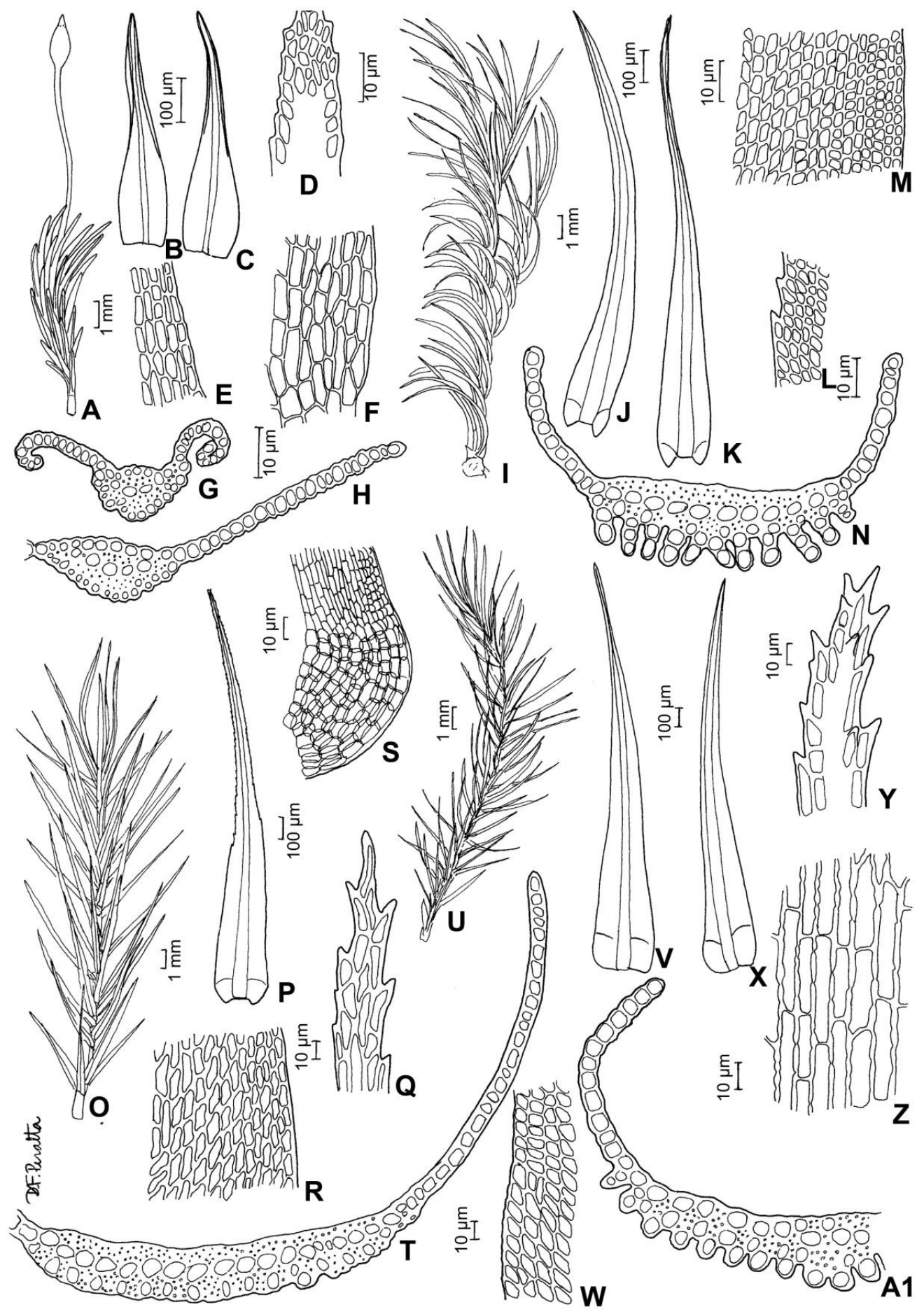

Fig. 8. Anisothecium varium (Hedw.) Mitt. A. aspecto do gametófito. B-C. filídios. D. células do ápice do filídio. E. células da margem do filídio. F. células da base do filídio. G. secção transversal da lâmina do filídio. H. secção transversal da base do filídio. Campylopus arctocarpus (Hornsch.) Mitt. I. aspecto do gametófito. J-K. filídios. L. células da margem no ápice do filídio. M. células da margem na base do filídio. N. secção transversal da lâmina do filídio. Campylopus carolinae Grout. O. aspecto do gametófito. P. filídio. Q. células do ápice do filídio. R. células da margem do filídio. S. células da base do filídio. T. secção transversal da lâmina do filídio. Campylopus cryptopodioides Broth. U. aspecto do gametófito. V-X. filídios. Y. células do ápice do filídio. W. células da margem do filídio. Z. células da base do filídio. A1. secção transversal da lâmina do filídio (A-H. Vital 1242; I-N. Pirani et al. 10331; O-T. O. Yano \& Wanderley 10861; U-A1. Câmara et al. 2068). 
lamelas, ápice do filídio pilífero ou acuminado, margem do filídio plana, inteira ou denticulada, não bordeada ou bordeada (ca. 10-15:1 compr.), células da lâmina retangulares, quadráticas ou irregulares, pouco alongadas ou isodiamétricas, lisas, parede celular espessada, porosa ou reta, células da base do filídio 1-10 fileira de células, muito infladas, marrons a laranja. Reprodução vegetativa ausente ou por filídios caducos. Seta longa, reta ou flexuosa, torcida ou lisa. Cápsula ereta, assimétrica ou simétrica, urna ovóide ou sub-cilíndrica, rômbica, superfície quando seca estriada, ânulo presente. Opérculo rostrado. Peristômio simples. Caliptra glabra.

\section{Chave para as espécies}

1. Paredes das células da base delgadas e translúcidas.

2. Secção transversal da costa com estereídios ventrais.

3. Células da região mediana quadráticas; gametófitos medianos; filídios agrupados no ápice; propagação vegetativa por filídios caducos

3'. Células da região mediana fusiformes; gametófitos pequenos; filídios dispostos igualmente em todo o caulídio; propagação vegetativa não conhecida 2.7. C. fragilis ssp. fragiliformis Seccão transversal da costa com hialocistos ventrais.

4. Filídios imbricados

4'. Filídios espalhados.

5. Células alares diferenciadas (infladas e coloridas); ápice do filídio pilífero e hialino; lamela dorsal presente.

5'. Células alares não diferenciadas; ápice do filídio concolor; lamela dorsal ausente ou com uma célula saliente.

6. Células da base quadráticas

c. occultus

6 '. Células da base retangulares (alongadas)

1 '. Paredes das células da base espessadas, concolor.

7. Células da base porosas.

8. Células alares infladas e coloridas; não orientadas.

9. Lamela dorsal ausente ou com uma célula saliente

2.15. C. thwaitesil

9'. Lamela dorsal presente

2.8. C. gastro-alaris

8'. Células alares não infladas e coloridas; obliquamente orientadas.

10. Imbricados.

2.13. C. richardii

10'. Espalhados.

11. Propagação vegetativa não conhecida

2.1. C. arctocarpus

11 '. Propagação vegetativa por filídios caducos

2.3. C. cryptopodioides

7'. Células da base não porosas.

12. Filídios dispostos em verticilos.

13. Células alares diferenciadas (infladas e coloridas); lamela dorsal presente; seta pêndula

2.16. C. trachyblepharon

13'. Células alares não diferenciadas; lamela dorsal ausente ou com uma célula saliente; seta reta

12'. Filídios dispostos igualmente em todo o caulídio.

14. Células da base não orientadas; células alares não diferenciadas; secção transversal da costa com estereídios ventrais; células da base quadráticas

14'. Células da base obliquamente orientadas; células alares diferenciadas (infladas e coloridas); secção transversal da costa com hialocistos ventrais; células da base retangulares (alongadas).

15. Hialocistos irregulares, filídios concentrados no ápice dos caulídio

15'. Hialocistos regulares, 2 fileiras distintas, a mais exterior claramente menor,

filídios igualmente dispostos em todo o caulídio

2.1. Campylopus arctocarpus (Hornsch.) Mitt., J. Linn. Soc. Bot. 12: 87. 1869.

Fig. $8 \mathrm{I}-\mathrm{N}$

Gametófitos medianos. Filídios lanceolados, dispostos igualmente em todo o caulídio, espalhados, células da região mediana quadráticas ou fusiformes, obliquamente orientadas, lisas, células da margem iguais as interiores, base não vaginante, células da base retangulares (alongadas), paredes das células da base espessadas, concolores, porosas, células alares não diferenciadas, ápice do filídio concolor. Costa curto-excurrente, secção transversal da costa com estereídios ventrais, lamela dorsal ausente ou com uma célula saliente. Filídios periqueciais iguais aos demais. Seta pêndula, propagação vegetativa não conhecida.

Material examinado: Minas Gerais, Santana do Riacho, córrego Duas Pontinhas, Pirani et al. 10331 (SP230723, SPF170909). 
Ocorre nos estados de BA, ES, GO, MG, MT, PI, PR, RJ, RS, SC e SP.

2.2. Campylopus carolinae Grout, Moss FI. N. Amer. 1: 249. 1939.

Fig. 8 O-T

Gametófitos pequenos. Filídios lanceolados, dispostos igualmente em todo o caulídio, espalhados, células da região mediana fusiformes, não orientadas, lisas, células da margem iguais as interiores, base não vaginante, células da base retangulares (alongadas), paredes das células da base delgadas e translúcidas, não porosas, células alares não diferenciadas, ápice do filídio pilífero e hialino ou concolor. Costa curtoexcurrente, secção transversal da costa com estereídios ventrais, lamela dorsal ausente ou com uma célula saliente. Filídios periqueciais iguais aos demais. Seta pêndula, propagação vegetativa não conhecida.

Material examinado: Minas Gerais, Santana do Riacho, Serra da Bandeirinha, O. Yano \& Wanderley 10861, 10913 (SP220554; SP220606).

Ocorre nos estados da BA, DF, MG, MS, MT, PA e SP. Na Serra do Cipó, cresce em solo. Esta é uma espécie característica de ambientes abertos e frequentemente relacionada a formações de cerrado aberto.

2.3. Campylopus cryptopodioides Broth., Bih. Kongl. Svenska Vetensk.-Akad. Handl. 26, 3(7): 9. 1900.

Fig. 8 U-A1

Gametófitos medianos. Filídios lanceolados, dispostos igualmente em todo o caulídio, espalhados, células da região mediana quadráticas, obliquamente orientadas, lisas, células da margem iguais as interiores, base não vaginante, células da base retangulares (alongadas), paredes das células da base espessadas, concolores, porosas, células alares não diferenciadas, ápice do filídio concolor. Costa curto-excurrente, secção transversal da costa com estereídios ventrais, lamela dorsal ausente ou com uma célula saliente. Filídios periqueciais iguais aos demais. Seta pêndula, propagação vegetativa por filídios caducos.

Material examinado: Minas Gerais, Santana do Riacho, Câmara et al. 2068 (SP419703); Dias Neto 286 (SP419853).

Ocorre nos estados de DF, ES, MG, PR, RJ, RS, SC e SP. Na Serra do Cipó, cresce em tronco caído. Esta é uma das poucas espécies do gênero que ocorrem sobre tronco caído, ela possui muitos filídios de tamanho reduzidos na porção distal do caulídio que são liberados por choque mecânico e funcionam como gemas.
2.4. Campylopus dichrostis (Müll. Hal.) Paris in Brotherus, Natürl. Pflanzenfam. 1(3): 333. 1901.

Fig. 9 A-G

Gametófitos medianos. Filídios lanceolados, dispostos igualmente em todo o caulídio, espalhados, células da região mediana quadráticas, não orientadas, lisas, células da margem iguais as interiores, células da base quadráticas, paredes das células da base espessadas, concolores, não porosas, células alares não diferenciadas, ápice do filídio concolor. Costa curto-excurrente, secção transversal da costa com estereídios ventrais, lamela dorsal ausente ou com uma célula saliente. Filídios periqueciais iguais aos demais. Seta pêndula, propagação vegetativa não conhecida.

Material examinado: Minas Gerais, Santana do Riacho, Pirani et al. 5546 (SP388843, SPF).

Ocorre nos estados da BA, GO, MG, RJ, RS, SC e SP. Na Serra do Cipó, cresce em solo.

2.5. Campylopus filifolius (Hornsch.) Mitt., J. Linn. Soc. Bot. 12: 76. 1869.

Fig. $9 \mathrm{H}-\mathrm{N}$

Gametófitos robustos. Filídio linear lanceolado, dispostos em verticilos, espalhados, células da região mediana quadráticas, não orientadas, lisas, células da margem iguais as interiores, base não vaginante, células da base retangulares (alongadas), paredes das células da base espessadas, concolores, não porosas, células alares não diferenciadas, ápice do filídio concolor. Costa curto-excurrente, secção transversal da costa com estereídios ventrais, lamela dorsal ausente ou com uma célula saliente. Filídios periqueciais iguais aos demais. Seta ereta, propagação vegetativa não conhecida.

Material examinado: Minas Gerais, Santana do Riacho, Dias Neto 156, 285 (SP419779; SP419851).

Ocorre nos estados de BA, CE, ES, MG, PE, PR, RJ, RR, RS, SC e SP. Na Serra do Cipó, cresce em solo. Esta espécie era tratada até recentemente no gênero Bryohumbertia, ela é facilmente identificada pelos filídios dispostos em fascículos.

2.6. Campylopus flexuosus (Hedw.) Brid., Mant. Musc. 4: 71. 1819 .

Fig. 9 O-T

Gametófitos medianos. Filídios lanceolados, dispostos igualmente em todo o caulídio, espalhados, células da região mediana quadráticas, obliquamente orientadas, lisas, células da margem iguais as interiores, base não vaginante, células da base retangulares (alongadas), paredes das células da base espessadas, concolores, 


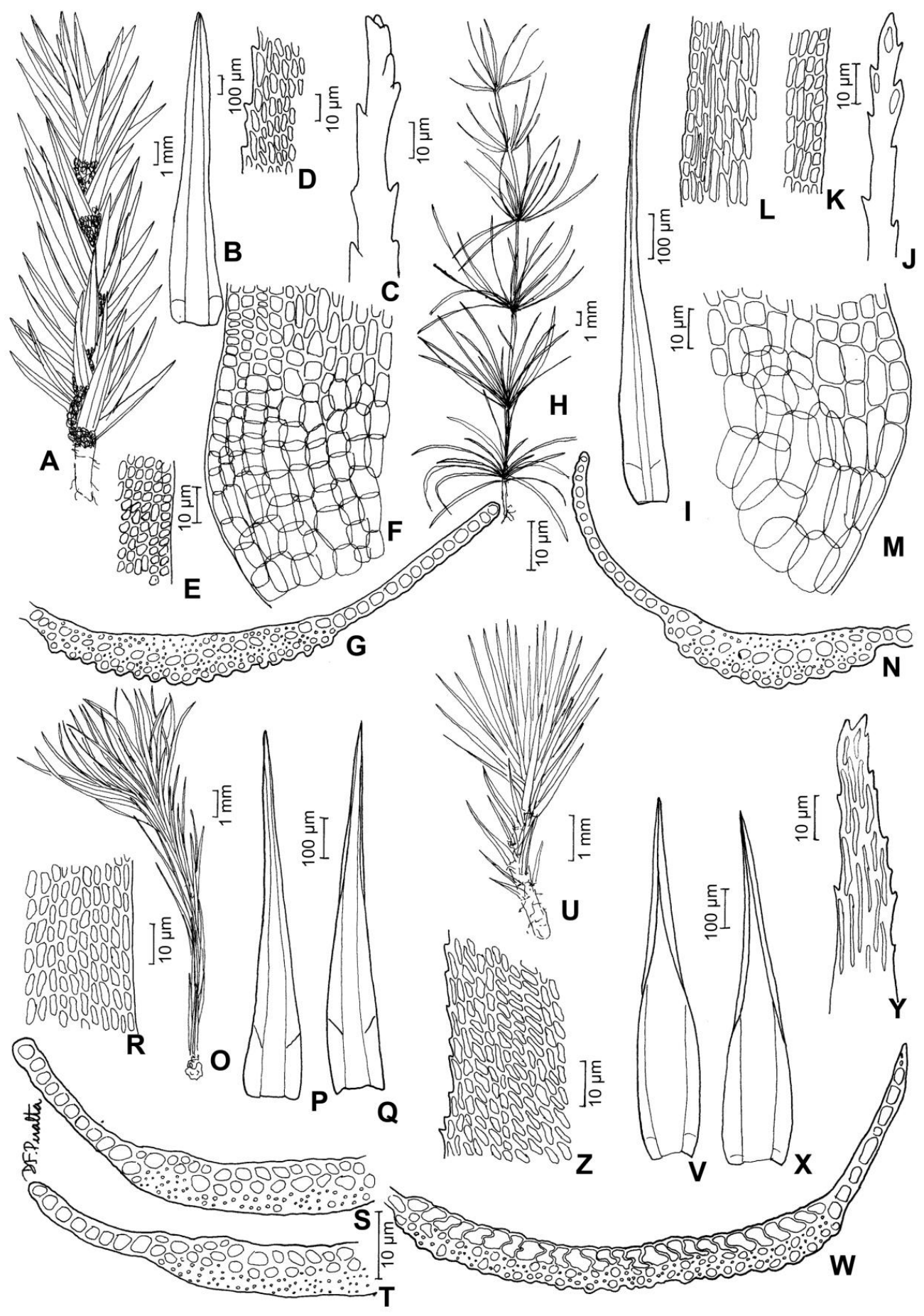

Fig. 9. Campylopus dichrostis (Müll. Hal.) Paris. A. aspecto do gametófito. B. filídio. C. ápice do filídio. D. células da margem na região superior do filídio. E. células da margem próximo a base do filídio. F. células da base do filídio. G. secção transversal da lâmina do filídio. Campylopus filifolius (Hornsch.) Mitt. H. aspecto do gametófito. I. filídio. J. ápice do filídio. K. células da margem no ápice do filídio. L. células da margem próximo a base do filídio. M. células da margem na base do filídio. N. secção transversal da lâmina do filídio. Campylopus flexuosus (Hedw.) Brid. O. aspecto do gametófito. P-Q. filídios. R. células da margem na base do filídio. S-T. secções transversais da lâmina do filídio. Campylopus fragilis ssp. fragiliformis (J.-P. Frahm) J.P. Frahm. U. aspecto do gametófito. V-X. filídios. Y. células do ápice do filídio. Z. células da margem próximo a base do filídio. W. secção transversal da lâmina do filídio (A-G. Pirani et al. 5546; H-N. Dias Neto 156; O-T. Câmara 1950; U-W. O. Yano 516 p.p.). 
Flora da Serra do Cipó, Minas Gerais: Briófitas (Anthocerotophyta, Bryophyta e Marchantiophyta)

não porosas, células alares diferenciadas (infladas e coloridas), ápice do filídio concolor. Costa curtoexcurrente, secção transversal da costa com hialocistos ventrais, camada dupla, lamela dorsal ausente ou com uma célula saliente. Filídios periqueciais iguais aos demais. Seta pêndula, propagação vegetativa não conhecida.

Material examinado: Minas Gerais, Santana do Riacho, Câmara 1950, 1989, 1989a (SP419663; SP419683; SP419684); Dias Neto 263, 294, 296 (SP419842; SP419854; SP419855).

Ocorre nos estados de PE, RJ, RS e SP. Na Serra do Cipó, cresce em solo.

2.7. Campylopus fragilis (Brid.) Bruch \& Schimp. ssp. fragiliformis (J.-P. Frahm) J.-P. Frahm, Flora Neotropica, monograph 54: 101. 1991.

Fig. 9 U-W

Gametófitos medianos. Filídios lanceolados, dispostos agrupados no ápice, espalhados, células da região mediana quadráticas, não orientadas, lisas, células da margem iguais as interiores, base não vaginante, células da base retangulares (alongadas), paredes das células da base delgadas e translúcidas, não porosas, células alares não diferenciadas, ápice do filídio concolor. Costa curto-excurrente, secção transversal da costa com estereídios ventrais, camada dupla, lamela dorsal ausente ou com uma célula saliente. Filídios periqueciais iguais aos demais. Seta pêndula, propagação vegetativa por filídios caducos.

Material examinado: Minas Gerais, Conceição do Mato Dentro, O. Yano 516 p.p. (SP135474).

Associada a Odontoschisma denudatum (Nees) Dumort. Ocorre nos estados de MG e RJ. Na Serra do Cipó, cresce em solo arenoso. Esta é uma espécie endêmica do Brasil.

2.8. Campylopus gastro-alaris (Müll. Hal.) Paris, Index Bryol. ed. 2, 1: 310. 1904.

Fig. 10 A-G

Gametófitos medianos. Filídios lanceolados, dispostos igualmente em todo o caulídio, espalhados, células da região mediana quadráticas, não orientadas, lisas, células da margem iguais as interiores, base não vaginante, células da base retangulares (alongadas), paredes das células da base espessada, concolor, porosa, células alares diferenciadas (infladas e coloridas), ápice do filídio concolor. Costa curto-excurrente, secção transversal da costa com estereídios ventrais, lamela dorsal presente. Filídios periqueciais iguais aos demais. Seta pêndula, propagação vegetativa não conhecida.
Material examinado: Minas Gerais, Santana do Riacho, Câmara 1968 (SP419679); Dias Neto 161 (SP419782).

Ocorre nos estado do AM, GO, MG e PA. Na Serra do Cipó, cresce em rocha.

2.9. Campylopus heterostachys (Hampe) A. Jaeger, Ber. Thätigk. St. Gallischen Naturwiss. Ges. 1870-1871: 421.1872.

Fig. $10 \mathrm{H}-\mathrm{L}$

Gametófitos medianos. Filídios lanceolados, dispostos igualmente em todo o caulídio, espalhados, células da região mediana quadráticas, obliquamente orientadas ou não orientadas, lisas, células da margem iguais as interiores, base não vaginante, células da base retangulares (alongadas), paredes das células da base delgadas e translúcidas, não porosas, células alares não diferenciadas, ápice do filídio concolor. Costa curto-excurrente, secção transversal da costa com hialocistos ventrais, camada dupla, lamela dorsal ausente ou com uma célula saliente. Filídios periqueciais iguais aos demais. Seta pêndula, propagação vegetativa não conhecida.

Material examinado: Minas Gerais, Conceição do Mato Dentro, O. Yano 479, 493 (SP135451; SP135460); Vital 7583 (SP136553); Santana do Riacho, O. Yano \& Wanderley 10686, 10906 p.p. (SP220381; SP220599); Dias Neto 174, 175, 187 (SP419791; SP419792; SP419801).

Associada a Calypogeia laxa Lindenb. \& Gottsche. Ocorre nos estados da BA, CE, GO, MG, MT, PI, PR, RJ, RR, RS e SP. Na Serra do Cipó, cresce em solo arenoso e rocha.

2.10. Campylopus julicaulis Broth., Denskschr. Akad. Wiss. Wien Math. Nat. KI. 83: 261. 1926.

Fig. $10 \mathrm{M}-\mathrm{S}$

Gametófitos medianos. Filídios lanceolados, dispostos igualmente em todo o caulídio, imbricados, células da região mediana quadráticas, não orientadas, lisas, células da margem iguais as interiores, base não vaginante, células da base retangulares (alongadas), paredes das células da base delgadas, translúcidas, não porosas, células alares não diferenciadas, ápice do filídio concolor. Costa curto-excurrente, secção transversal da costa com hialocistos ventrais, camada dupla, lamela dorsal ausente ou com uma célula saliente. Filídios periqueciais iguais aos demais. Seta pêndula, propagação vegetativa não conhecida.

Material examinado: Minas Gerais, Santana do Riacho, Dias Neto192 (SP419803).

Ocorre nos estados do PR, RJ, RS, SC e SP. Esta é uma espécie endêmica do Brasil. 


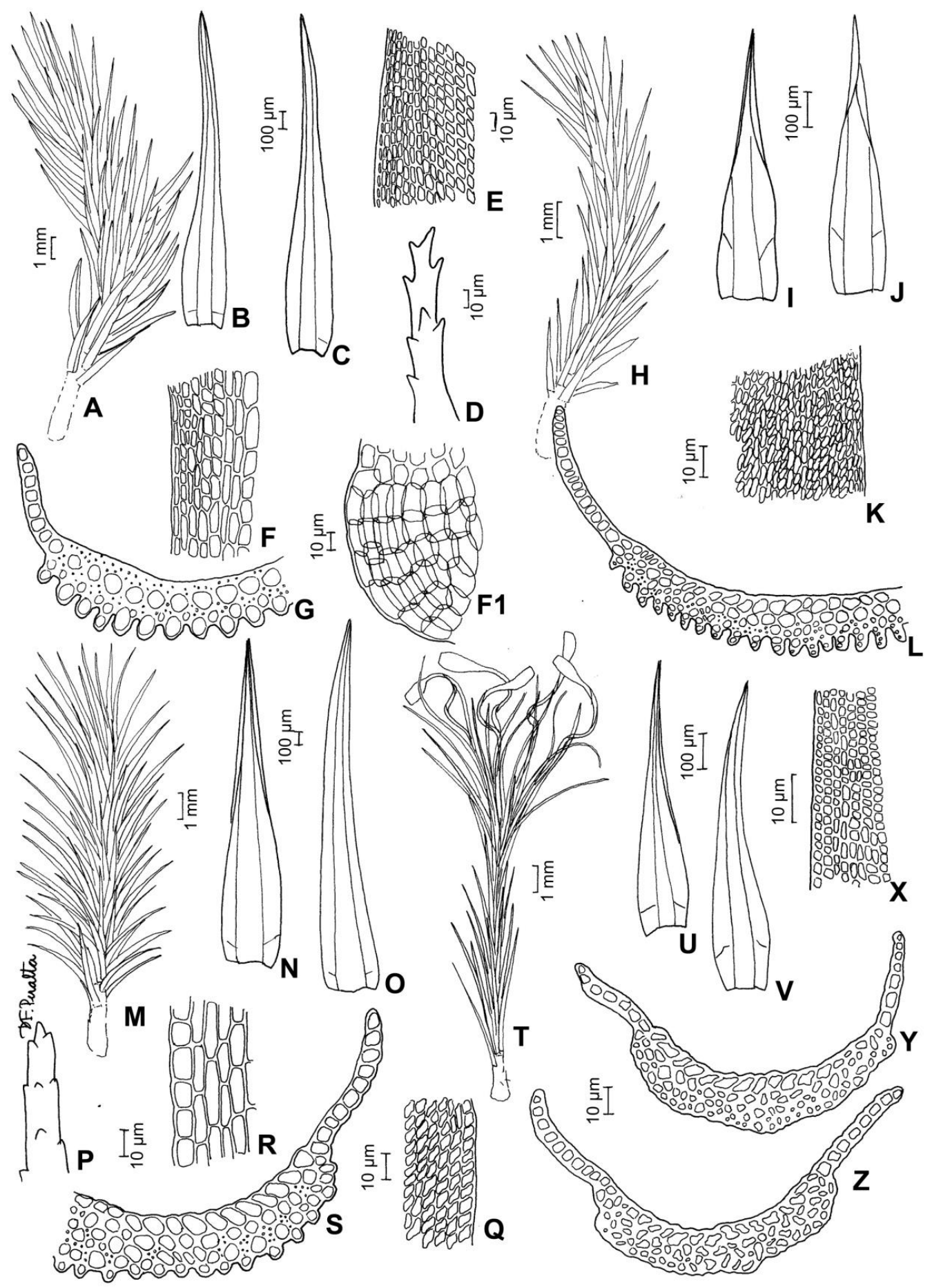

Fig. 10. Campylopus gastro-alaris (Müll. Hal.) Paris. A. aspecto do gametófito. B-C. filídios. D. ápice do filídio. E. células da margem próximo a base do filídio. F. células da margem na base do filídio. F1. Células da base do filídio, G. secção transversal da lâmina do filídio. Campylopus heterostachys (Hampe) A. Jaeger. H. aspecto do gametófito. I-J. filídios. K. células da margem próximo a base do filídio. L. secção transversal da lâmina do filídio. Campylopus julicaulis Broth. M. aspecto do gametófito. NO. filídios. P. ápice do filídio. Q. células da margem próximo a base do filídio. R. células da margem na base do filídio. S. secção transversal da lâmina do filídio. Campylopus occultus Mitt. T. aspecto do gametófito. U-v. filídios. X. células da margem próximo a base do filídio. Y-Z. secções transversais da lâmina do filídio (A-G. Câmara 1968; H-L. O. Yano 479; M-S. Dias Neto192; T-Z. O. Yano \& Wanderley 10685 p.p.). 
2.11. Campylopus occultus Mitt., J. Linn. Soc. Bot. $12: 86.1869$.

Fig. $10 \mathrm{~T}-\mathrm{Z}$

Gametófitos medianos. Filídios lanceolados, dispostos igualmente em todo o caulídio, espalhados, células da região mediana quadráticas, obliquamente orientadas ou não orientadas, lisas, células da margem iguais as interiores, base não vaginante, células da base quadráticas, paredes das células da base delgadas e translúcidas, não porosas, células alares não diferenciadas, ápice do filídio concolor. Costa curto-excurrente, secção transversal da costa com hialocistos ventrais, camada dupla, lamela dorsal ausente ou com uma célula saliente. Filídios periqueciais iguais aos demais. Seta pêndula, propagação vegetativa não conhecida.

Material examinado: Minas Gerais, Santana do Riacho, O. Yano \& Wanderley 10685 p.p. (SP220380); Dias Neto 140 p.p., 141, 211, 213, 215 (SP419771; SP419772; SP419816; SP419817; SP419819).

Associada a Dicranella hilariana (Mont.) Mitt. e Telaranea nematodes (Gottsche ex Austin) M. Howe. Ocorre nos estados da BA, DF, ES, GO, MA, MG, MS, PA, PR, RJ, RR, RS, SC e SP. Na Serra do Cipó, cresce em solo arenoso.

2.12. Campylopus pilifer Brid., Mant. Musc.: 72. 1819.

Fig. $11 \mathrm{~A}-\mathrm{E}$

Gametófitos medianos ou robustos. Filídios lanceolados, dispostos igualmente em todo o caulídio, espalhados, células da região mediana quadráticas, obliquamente orientadas ou não orientadas, lisas, células da margem iguais as interiores, base não vaginante, células da base retangulares (alongadas), paredes das células da base delgadas e translúcidas, não porosas, células alares diferenciadas (infladas e coloridas), ápice do filídio pilífero e hialino. Costa curto-excurrente, secção transversal da costa com hialocistos ventrais, camada dupla, lamela dorsal presente. Filídios periqueciais iguais aos demais. Seta pêndula, propagação vegetativa não conhecida.

Material examinado: Minas Gerais, Congonhas do Norte, Serra da Carapina Pirani et al. 4126, 5176, 5639, 5757, 5758 (SP284254, SPF170902; SPF, SP379509; SP389356, SPF; SP432341, SPF; SP432342, SPF); Santana do Riacho, Pirani 5543, 6260, 9319-A, 12104 (SP388841, SPF; SP432411, SPF; SP222547, SPF170903; SP386343, SPF); Câmara 1912, 1914, 1915, 1951; 2025 (SP419649; SP419650; SP419651; SP419664; SP419694); Câmara et al. 2146 (SP419718); Dias Neto 176, 202, 207, 210, 260, 261, $281 \quad$ (SP419793; SP419810; SP419813; SP419815; SP419839; SP419840; SP419850).

Ocorre nos estados de AL, AM, BA, CE, DF, ES, MG, MT, PA, PE, PR, RJ, RR, RS e SP. Na Serra do Cipó, cresce em rocha e solo. Esta espécie apresenta o ápice dos filídios caracteristicamente pilíferos e hialinos, além de apresentar uma coloração verde opaco em contraste ao verde-amarelado e brilhante das demais espécies.

2.13. Campylopus richardii Brid., Mant. Musc.: 73. 1819.

Fig. 11 F-K

Gametófitos medianos. Filídios lanceolados, dispostos igualmente em todo o caulídio, imbricados, células da região mediana fusiformes, obliquamente orientadas, lisas, células da margem iguais as interiores, base não vaginante, células da base retangulares (alongadas), paredes das células da base espessadas, concolores, porosas, células alares não diferenciadas, ápice do filídio pilífero e hialino ou concolores. Costa curto-excurrente, secção transversal da costa com estereídios ventrais, lamela dorsal ausente ou com uma célula saliente. Filídios periqueciais iguais aos demais. Seta pêndula, propagação vegetativa não conhecida.

Material examinado: Minas Gerais, Conceição do Mato Dentro, O. Yano 510 (SP135472).

Ocorre nos estados da BA, CE, ES, MG, PE, RJ, RR, SC e SP. Na Serra do Cipó, cresce em solo. Esta espécie é facilmente diferenciada pelas células da lâmina muito porosas em toda a extensão do filídio e pela coloração verde enegrecida.

2.14. Campylopus savannarum (Müll. Hal.) Mitt., J. Linn. Soc. Bot. 12: 85. 1869.

Fig. $11 \mathrm{~L}-\mathrm{Q}$

Gametófitos medianos ou robustos. Filídios lanceolados, dispostos igualmente em todo o caulídio, espalhados, células da região mediana quadráticas, não orientadas, lisas, células da margem iguais as interiores, base não vaginante, células da base quadráticas, paredes das células da base espessadas, concolores, não porosas, células alares não diferenciadas, ápice do filídio concolor. Costa curtoexcurrente, secção transversal da costa com estereídios ventrais, lamela dorsal ausente ou com uma célula saliente. Filídios periqueciais iguais aos demais. Seta pêndula, propagação vegetativa não conhecida.

Material examinado: Minas Gerais, Itambé do Mato Dentro, Vital 7617 (SP136572); Santana do Riacho, Giulietti et al. 9749 (SP222576, SPF 42411); O. Yano \& Wanderley 10628 (SP220323); Serra da Bandeirinha, O. Yano \& Wanderley 10774 (SP220467); Formoso, Parque Nacional Grande Sertão Veredas, Silva et al. 3443 (SP284253).

Ocorre nos estados do AM, BA, CE, GO, MA, MG, MS, MT, PA, PE, PI, PR, RJ, RR, SE, SP e TO. $\mathrm{Na}$ Serra do Cipó, cresce em solo e tronco podre. Esta espécie é encontrada comumente em solo arenoso, onde forma extensos tapetes. 


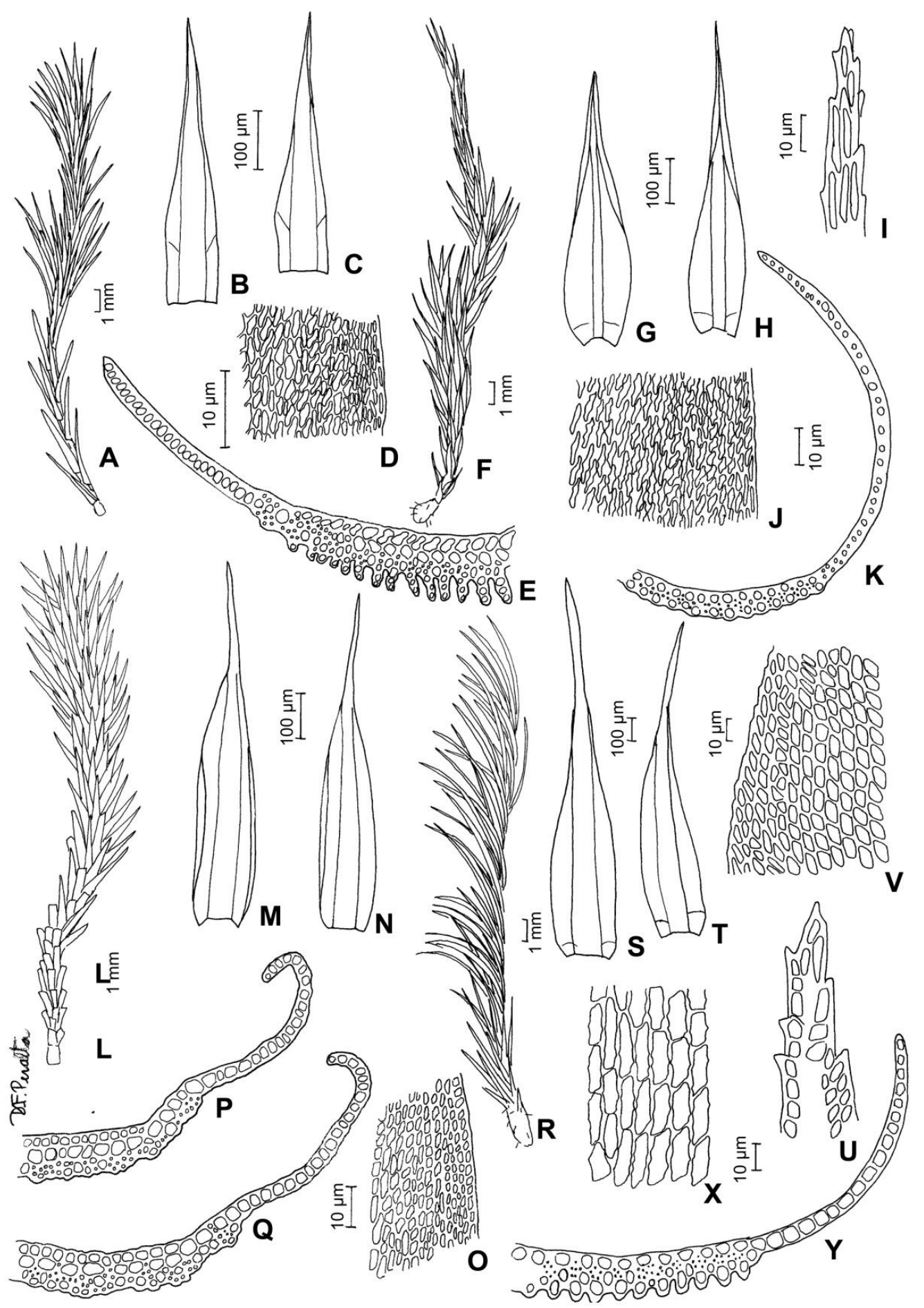

Fig. 11. Campylopus pilifer Brid. A. aspecto do gametófito. B-C. filídios. D. células da margem próximo a base do filídio. e. secção transversal do filídio. Campylopus richardii Brid. F. aspecto do gametófito. G-h. filídios. I. ápice do filídio. J. células da margem próximo a base do filídio. K. secção transversal do filídio. Campylopus savannarum (Müll. Hal.) Mitt. L. aspecto do gametófito. M-N. filídios. O. células da margem próximo a base do filídio. P-Q. secção transversal do filídio. Campylopus thwaitesii (Mitt.) A. Jaeger. R. aspecto do gametófito. S-T. filídios. U. ápice do filídio. V. células da margem na região mediana do filídio. X. células da margem próximo a base do filídio. Y. secção transversal do filídio (A-E. Pirani et al. 4126; F-K. O. Yano 510; L-N. Vital 7617; R-Y. Dias Neto 250). 
Flora da Serra do Cipó, Minas Gerais: Briófitas (Anthocerotophyta, Bryophyta e Marchantiophyta)

2.15. Campylopus thwaitesii (Mitt.) A. Jaeger, Ber. Thätigk. St. Gallischen Naturwiss. Ges. 1870-71: 419. 1872.

Fig. $11 \mathrm{R}-\mathrm{Y}$

Gametófitos medianos. Filídios lanceolados ou linear-lanceolados, dispostos igualmente em todo o caulídio, espalhados, células da região mediana quadráticas, não orientadas, lisas, células da margem iguais as interiores, base não vaginante, células da base retangulares (alongadas), paredes das células da base espessadas, concolores, porosas, células alares diferenciadas (infladas e coloridas), ápice do filídio concolor. Costa curto-excurrente, secção transversal da costa com estereídios ventrais, lamela dorsal ausente ou com uma célula saliente. Filídios periqueciais iguais aos demais. Seta pêndula, propagação vegetativa não conhecida.

Material examinado: Minas Gerais, Santana do Riacho, Dias Neto 250 (SP419833).

Ocorre nos estados da BA, DF, MG, RJ, RS, SC e SP. Na Serra do Cipó ocorre em solo.

2.16. Campylopus trachyblepharon (Müll. Hal.) Mitt., J. Linn. Soc. Bot. 12: 80. 1869.

Fig. 12 A-F

Gametófitos medianos ou robustos. Filídios lanceolados ou linear-lanceolados, dispostos em verticilos, espalhados, células da região mediana quadráticas, não orientadas, lisas, células da margem iguais as interiores, base não vaginante, células da base retangulares (alongadas), paredes das células da base espessadas, concolores, não porosas, células alares diferenciadas (infladas e coloridas), ápice do filídio concolor. Costa curto-excurrente, secção transversal da costa com estereídios ventrais, lamela dorsal presente. Filídios periqueciais iguais aos demais. Seta pêndula, propagação vegetativa não conhecida.

Material examinado: Minas Gerais, Conceição do Mato Dentro, O. Yano 506, 538 (SP135468; SP135492); Vital 7575 (SP136546); Santana do Riacho, O. Yano \& Wanderley 10669 (SP220364); Serra da Bandeirinha, O. Yano \& Wanderley 10786, 10848 (SP220479; SP220541); Câmara 1908 (SP419647).

Ocorre nos estados da BA, ES, GO, MG, MT, PR, RJ, RS, SC, SP e TO. Na Serra do Cipó, cresce em rocha, solo arenoso e tronco vivo. Esta é a espécie que apresenta o hábito mais robusto e maior hábito entre as encontradas, ocorre comumente em solo arenoso.

\section{Dicranella (Müll. Hal.) Schimp.}

Gametófitos acrocárpicos, pequenos, delicados, formando tufos. Caulídios primários eretos, tomentosos. Filídios lanceolados, planos, espiralados, planos quando secos, base do filídio auriculada. Costa única, percurrente, estreita (1/4 a 1/5 da largura do filídio), secção transversal com camada de estereídios distinta, lâmina do filídio sem lamelas, ápice do filídio acuminado, margem do filídio plana, inteira, não bordeada, células da lâmina quadrático-irregulares, pouco alongadas ou isodiamétricas, lisas, parede celular delgada, reta, células da base do filídio não diferenciadas. Reprodução vegetativa ausente. Seta longa, reta, lisa. Cápsula ereta, simétrica, urna ovóide, rômbica, superfície quando seca estriada, ânulo presente. Opérculo rostrado. Peristômio simples. Caliptra glabra.

3.1. Dicranella hilariana (Mont.) Mitt., J. Linn. Soc. Bot. 12: 31. 1869.

Fig. 12 G-M

Gametófitos pequenos. Filídios lanceolados, dispostos igualmente em todo o caulídio, espalhados, células da região mediana retangulares, lisas, células da margem iguais as interiores, base não vaginante, células da base retangulares (alongadas), paredes das células da base delgadas e translúcidas, não porosas, células alares não diferenciadas, ápice do filídio acuminado. Costa subpercurrente. Filídios periqueciais iguais aos demais. Seta ereta, simétrica.

Material examinado: Minas Gerais, Santana do Riacho, O. Yano \& Wanderley 10685 p.p., 10710 p.p. (SP220380; SP220405).

Associada a Gemmabryum acuminatum (Harv.) J.R. Spence \& H.P. Ramsay, Campylopus occultus Mitt. e Paracromastigum pachyrrhizon (Nees) Fulford. Ocorre nos estados do AC, AM, BA, CE, ES, GO, MA, MG, MS, MT, PA, PB, PE, RJ, RO, RR, SC e SP. Na Serra do Cipó, cresce em solo arenoso. Esta é uma espécie bastante delicada e quando está sem esporófito pode ser confundida com espécies do gênero Anisothecium.

\section{Holomitrium Brid.}

Gametófitos acrocárpicos, medianos, formando tufos. Caulídios primários eretos, tomentosos, ramos secundários ascendentes. Filídios lanceolados, planos ou canaliculados, espiralados, quando secos contorcidos, base do filídio auriculada. Costa única, percurrente, estreita (1/4 a 1/5 da largura do filídio), secção transversal com camada de estereídios distinta, lâmina do filídio sem lamelas, ápice do filídio acuminado, margem do filídio plana, denticulada, não bordeada, células da lâmina quadrático-irregulares, isodiamétricas, lisas, parede celular espessada, reta, células da base do filídio 1-10 fileira de células, muito infladas. Filídios periqueciais muito maiores do que os demais e envolvendo a seta. Reprodução vegetativa por filídios caducos. Seta longa, reta, lisa. Cápsula ereta, simétrica, sub-cilíndrica, rômbica, superfície 


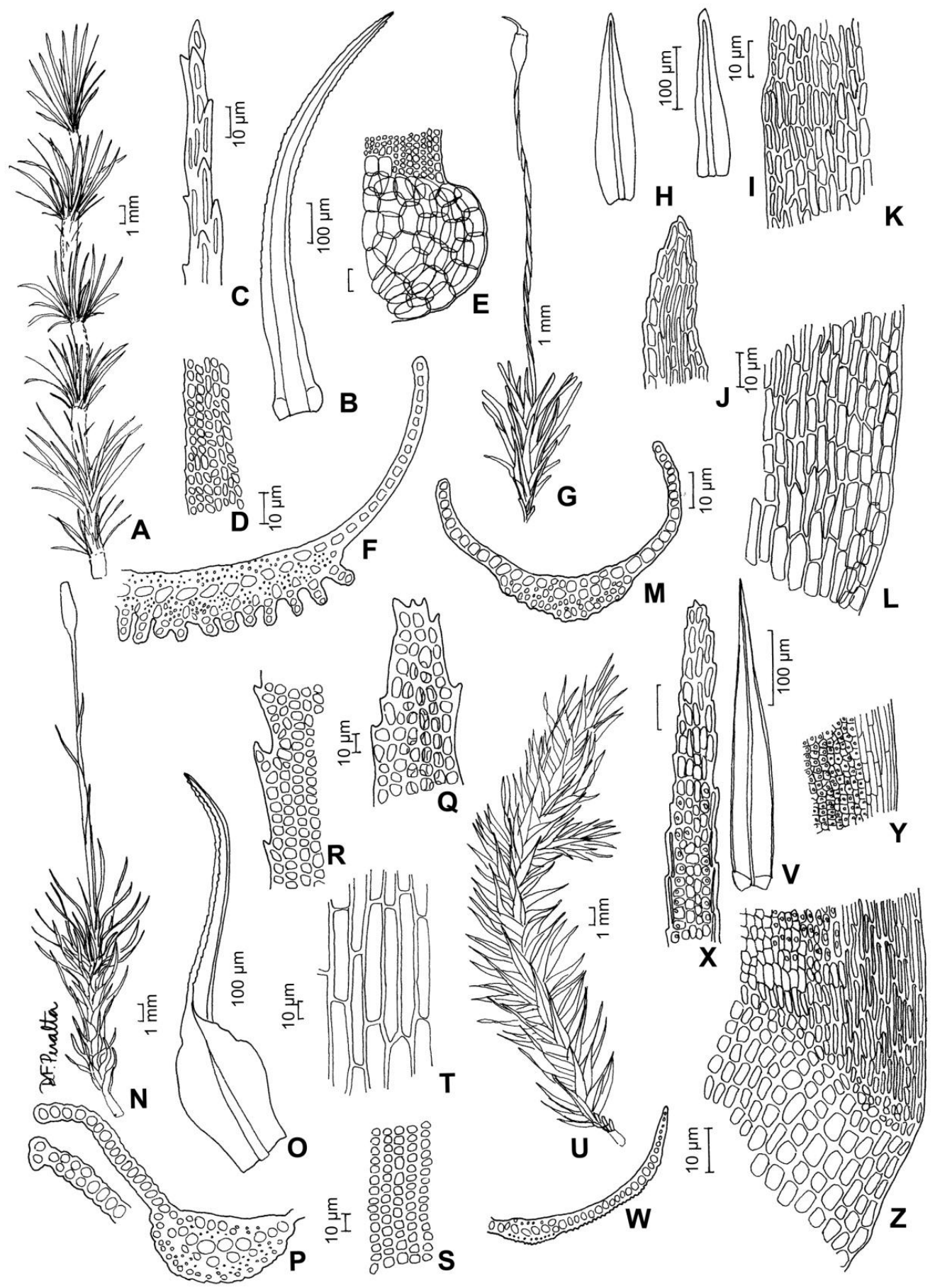

Fig. 12. Campylopus trachyblepharon (Müll. Hal.) Mitt. A. aspecto do gametófito. B. filídio. C. ápice do filídio. D. células da margem próximo a base do filídio. E. células da base do filídio. F. secção transversal do filídio. Dicranella hilariana (Mont.) Mitt. G. aspecto do gametófito. H-I. filídios. J. células do ápice do filídio. K. células da margem do filídio. L. células da base do filídio. M. secção transversal do filídio. Holomitrium crispulum Mart. N. aspecto do gametófito. O. filídio. P. secção transversal do filídio. Q. células do ápice do filídio. R. células da margem do filídio. S. células da lâmina do filídio. T. células da base do filídio. Leucoloma tortellum (Mitt.) A. Jaeger. U. aspecto do gametófito. V. filídio. X. células do ápice do filídio. Y. células da lâmina e margem do filídio. Z. células da base do filídio. W. secção transversal do filídio (A-F. O. Yano 506; G-M. O. Yano \& Wanderley 10685 p.p.; N-T. Vital 1227; U-W. Schäfer-Verwimp 9942). 
Flora da Serra do Cipó, Minas Gerais: Briófitas (Anthocerotophyta, Bryophyta e Marchantiophyta)

quando seca estriada, ânulo presente. Opérculo rostrado. Peristômio simples. Caliptra glabra.

4.1. Holomitrium crispulum Mart., Icon. Plant. Cryptog. 35. pl. 18. 1828.

Fig. $12 \mathrm{~N}-\mathrm{T}$

Gametófitos robustos. Filídios lanceolados, dispostos igualmente em todo o caulídio, imbricados, células da região mediana quadráticas, lisas, células da margem iguais as interiores, base amplamente vaginante, células da base retangulares (alongadas), paredes das células da base delgadas e translúcidas, porosas, células alares não diferenciadas, ápice do filídio acuminado. Costa subpercurrente. Filídios periqueciais muito maiores do que os demais e envolvendo a seta. Seta ereta, cápsula simétrica.

Material examinado: Minas Gerais, Conceição do Mato Dentro, Vital 1227 (SP89445).

Ocorre nos estados da BA, DF, ES, GO, MG, PE, PR, RJ, RS, SC e SP. Na Serra do Cipó, cresce em tronco caído. O hábito robusto e a presença dos filídios periqueciais muito longos e envolvendo a cápsula são características marcantes desta espécie.

\section{Leucoloma Brid.}

Gametófitos acrocárpicos, medianos, formando tufos. Caulídios primários eretos, tomentosos, ramos secundários ascendentes. Filídios lanceolados, planos, espiralados, planos quando secos, base do filídio auriculada. Costa única, percurrente ou excurrente, estreita (1/4 a 1/5 da largura do filídio), secção transversal com camada de estereídios distinta, lâmina do filídio sem lamelas, ápice do filídio acuminado, margem do filídio plana, inteira, bordeada (ca. 10-15:1 compr.), células da lâmina retangulares, quadráticas ou irregulares, isodiamétricas, papilosas, parede celular espessada, reta, células da base do filídio 1-10 fileira de células, muito infladas, marrons a laranja. Reprodução vegetativa ausente. Seta curta, reta, lisa. Cápsula ereta, simétrica, sub-cilíndrica, rômbica, superfície quando seca estriada. Ânulo presente. Opérculo rostrado. Peristômio simples. Caliptra glabra.

5.1. Leucoloma tortellum (Mitt.) A. Jaeger, Ber. Thätigk. St. Gallischen Natuwiss. Ges. 1870-1871: 413. 1872.

Fig. 12 U-W

Gametófitos medianos ou robustos. Filídios lanceolados ou linear-lanceolados, dispostos igualmente em todo o caulídio, espalhados, células da região mediana quadráticas ou retangulares, não orientadas, papilosas, células da margem várias camadas de células longas, base não vaginante, células da base retangulares (alongadas), paredes das células da base espessadas, concolores, não porosas, células alares diferenciadas (infladas e coloridas), ápice do filídio concolor, costa percurrente. Filídios periqueciais iguais aos demais. Seta ereta, simétrica, propagação vegetativa não conhecida.

Material examinado: Minas Gerais, Santana do Riacho, Schäfer-Verwimp 9942 (SP389038).

Ocorre nos estados de AM, CE, MG, MT, PA, $\mathrm{RO}, \mathrm{RR}$ e SP. Na Serra do Cipó, cresce em rocha. Esta é a única espécie da família que ocorre na Serra que apresenta o filídio bordeado, a margem dos filídios é facilmente visível sob lupa.

\section{Entodontaceae}

É uma família pequena mas amplamente distribuída no Brasil, caracterizada principalmente pela costa costa curta e dupla e pelas células alares bem diferenciadas na base. Ocorre principalmente como corticícola e terrestre e está sempre associada a locais ventilados e expostos diretamente ao sol. Para a identificação das espécies é necessário que as espécies estejam com esporófitos. No Brasil ocorrem três gêneros e 24 espécies; na Serra do Cipó ocorrem duas espécies do gênero Erythrodontium.

Bibliografia básica - Gradstein et al. (2001); Sharp et al. (1994); Yano \& Peralta (2009).

\section{Erythrodontium Hampe}

Gametófitos pleurocárpicos, medianos, formando tapetes. Caulídios primários prostrados, tomentosos, ramos secundários prostrados. Filídios lanceolados ou ovados, côncavos, aplainados, quando secos imbricados ou planos, costa dupla, curta, ca. 1/10 a 1/20 do compr., estreita, ápice do filídio obtuso ou agudo, margem do filídio plana, denticulada, não bordeada, células da lâmina longo-hexagonais ou lineares, longitudinalmente muito alongadas, lisas, parede celular delgada, reta, células da base do filídio quadrático-irregulares. Seta longa, reta. Cápsula ereta, simétrica, urna ovóide, rômbica, superfície lisa quando seca. Opérculo rostrado, peristômio duplo. Caliptra glabra.

Os filídios deste gênero são fortemente imbricados quando secos, sendo dessa maneira fácil sua diferenciação. 
1. Seta amarelada, exóstomo papiloso

1.1. E. longisetum

1'. Seta avermelhada, exóstomo transversalmente estriado.

1.1. Erythrodontium Iongisetum (Hook.) Paris, Index Bryol.: 436. 1869.

Fig. $13 \mathrm{~A}-\mathrm{F}$

Gametófitos moderadamente robustos, juláceos. Filídios imbricados, oblongo-ovalados ou raramente ovalados, côncavos, abruptamente arredondados para o ápice, decurrente, costa curta $e$ dupla ou comumente ausente; células lineares, curtas e subflexuosas para o ápice; as alares curtoretangulares (mais larga do que longa). Seta amarelada.

Material examinado: Minas Gerais, Santana do Riacho, Cachoeira Farofa, O. Yano \& Wanderley 10673 , 10699 (SP220368; SP220394); Serra da Bandeirinha, $O$ Yano \& Wanderley 10724, 10752, 10841 (SP220418; SP220446; SP220534).

Ocorre nos estados de CE, GO, MG, MS, MT, PE, PR, RJ, RS, SC e SP. Na Serra do Cipó, cresce em tronco vivo.

1.2. Erythrodontium squarrosum (Hampe) Paris, Index Bryol. ed. 2, 2: 159. 1904.

Fig. $13 \mathrm{G}-\mathrm{L}$

Gametófitos pequenos, verdes a avermelhados, juláceos. Filídios imbricados, côncavos, suborbiculares a curto oblongo-ovalados, abruptamente arredondados; células lineares; as alares sub-quadráticas, comumente atingindo a costa. Seta avermelhada.

Material examinado: Minas Gerais, Morro do Pilar, Vital 7593 (SP136558); Santana do Riacho, O. Yano \& Wanderley 10618 (SP220313).

Ocorre nos estados do DF, ES, GO, MG, MS, MT, PA, PR, RJ, RS, SC e SP. Na Serra do Cipó, cresce em tronco de árvore.

\section{Erpodiaceae}

É uma família amplamente distribuída no Brasil, caracterizada pela ausência de costa e as células da lâmina caracteristicamente hexagonais. Ocorre principalmente como corticícola e sempre associada a locais ventilados e expostos diretamente. Para a identificação das espécies é necessário analisar o formato dos filídios. No Brasil ocorrem dois gêneros e sete espécies; na Serra do Cipó ocorre uma espécie do gênero Erpodium.
Bibliografia básica - Gradstein et al. (2001); Sharp et al. (1994); Vital (1980); Yano \& Costa (2000); Yano \& Peralta (2009).

\section{Erpodium (Brid.) Brid.}

Gametófitos cladocárpicos, pequenos, delicados, formando tapetes. Caulídios primários prostrados, tomentosos, ramos secundários prostrados. Filídios lanceolados ou ovados, marcadamente assimétricos ou côncavos, espiralados, quando secos imbricados. Costa ausente, ápice do filídio apiculado ou agudo, margem do filídio plana, inteira, não bordeada, células da lâmina quadrático-irregulares, isodiamétricas, lisas, parede celular delgada, reta, células da base do filídio quadrático-irregulares, filídios periqueciais diferenciados. Seta curta, reta. Cápsula imersa, reta, simétrica, urna sub-cilíndrica, rômbica, superfície lisa quando seca. Opérculo rostrado. Peristômio simples. Caliptra glabra.

1.1. Erpodium coronatum (Hook. \& Wilson) Mitt., J. Linn. Soc. Bot. 12: 403. 1869.

Fig. $13 \mathrm{M}-\mathrm{R}$

Gametófitos pequenos, delicados, formando tapetes. Caulídios primários prostrados. Filídios lanceolado ou ovados, espiralados, quando secos imbricados. Costa ausente, ápice do filídio apiculado, margem do filídio plana, inteira, células da lâmina quadrático-irregulares, células da base do filídio quadrático-irregulares, filídios periqueciais diferenciados. Seta curta, reta. Cápsula imersa.

Material examinado: Minas Gerais, Conceição do Mato Dentro, O. Yano 541 (SP135495); Shepherd s.n. (SP147598); Santana do Riacho, O. Yano \& Wanderley 10611, 10620, 10636, 10705, 10922 p.p. (SP220306; SP220315; SP220331; SP220400; SP220615).

Associada a Helicophyllum torquatum (Hook.) Brid. Ocorre nos estados do BA, CE, DF, GO, MA, MG, MS, MT, PB, PI, PR, RJ, SP e TO. Na Serra do Cipó, cresce em tronco vivo e rocha. Esta é uma espécie que apresenta o hábito prostrado e quando apresenta esporófitos estes surgem em pequenas ramificações eretas estão imersos nos filídios periqueciais. 
Flora da Serra do Cipó, Minas Gerais: Briófitas (Anthocerotophyta, Bryophyta e Marchantiophyta)

\section{Fabroniaceae}

É uma família amplamente distribuída no Brasil, caracterizada principalmente pelo hábito delicado, a costa simples e as células alares fortemente diferenciadas. Ocorre comumente como corticícola e está sempre associada a locais ventilados e expostos diretamente. Para a identificação é necessário análise das células da margem e lâmina do filídio. No Brasil ocorrem dois gêneros e duas espécies; na Serra do Cipó ocorre uma espécie do gênero Fabronia.

Bibliografia básica - Gradstein et al. (2001); Sharp et al. (1994); Yano \& Peralta (2009).

\section{Fabronia Raddi}

Gametófitos pleurocárpicos, pequenos, delicados ou medianos, formando tapetes. Caulídios primários prostrados, poucos rizóides, ramos secundários ascendentes, paráfilos presentes. Filídios lanceolados, planos, espiralados, planos quando secos. Costa única, atingindo até $1 / 2$ ou $3 / 4$ compr. do filídio ou percurrente, estreita, ápice do filídio pilífero ou acuminado, margem do filídio plana, inteira ou denticulada, não bordeada, células da lâmina fusiformes ou longo-hexagonais, pouco alongadas, lisas, parede celular delgada, reta, células da base do filídio quadrático-irregulares, filídios periqueciais diferenciados. Seta longa, reta, torcida ou lisa Cápsula ereta, simétrica, urna ovóide ou sub-cilíndrica, rômbica, ânulo presente. Opérculo cônico ou rostrado. Peristômio simples, rudimentar. Caliptra glabra.

Chave para variedades

1. Costa $1 / 2$ compr., margem denteada, cada dente formado por 1 célula

1.1. F. ciliaris var. ciliaris

1 '. Costa $3 / 4$ compr., margem inteira ou denticulada 1.2. F. ciliaris var. polycarpa

1.1. Fabronia ciliaris (Brid.) Brid. var. ciliaris, Bryol. Univ. 2: 171. 1827.

Fig. $13 \mathrm{~S}-\mathrm{Y}$

Gametófitos pequenos. Filídios lanceolados a oblongos ou ovalados, abruptamente acuminados, algumas vezes pilíferos, margem inteira a longodenteada, dentes de 1 célula simples; costa terminando perto da metade, células superiores rombóides, marginais mais curtas; células alares diferenciadas.

Material examinado: Minas Gerais, Santana do Riacho, Serra da Bandeirinha, O. Yano \& Wanderley 10723 , 10753 (SP220417; SP220447).

Ocorre nos estados da BA, CE, GO, MG, MT, PE e RS. Na Serra do Cipó, cresce em tronco vivo.

1.2. Fabronia ciliaris (Brid.) Brid. var. polycarpa (Hook.) W.R. Buck, Brittonia 35(3): 251. 1983.

Fig. $14 \mathrm{~A}-\mathrm{F}$

Gametófitos delicados. Filídios ovaladolanceolados, gradualmente acuminados, margem inteira a regularmente denticulada. Costa ocupando $3 / 4$ compr. do filídio, células alares gradualmente diferenciadas.

Material examinado: Minas Gerais, Santana do Riacho, Serra da Bandeirinha, O. Yano \& Wanderley 10712 , 10713, 10722, 10726, 10915 (SP220407; SP220408; SP220416; SP220420; SP220608).
Ocorre nos estados de AL, AM, BA, CE, DF, ES, GO, MG, MS, MT, PB, PE, PR, RJ, RS, SC, SE e SP. Na Serra do Cipó, cresce em tronco vivo.

\section{Fissidentaceae}

É uma família amplamente distribuída no Brasil, caracterizada pela base vaginante e disposição dística dos filídios. Ocorre nos mais variados substratos. Para a identificação das espécies é necessário análise da morfologia das células da lâmina do filídio. A família possui apenas um gênero e no Brasil ocorrem 78 espécies; na Serra do Cipó ocorrem 10 espécies.

Bibliografia básica - Gradstein et al. (2001): Pursell (2007); Sharp et al. (1994); Yano \& Oliveira-eSilva (1997); Yano \& Peralta (2009).

\section{Fissidens Hedw.}

Gametófitos acrocárpicos, pequenos, delicados ou medianos, formando tufos. Caulídios primários eretos, poucos rizóides, ramos secundários ascendentes. Filídios ligulados ou lanceolados, marcadamente assimétricos, planos, dísticos, planos quando secos, base do filídio diferenciada em lâmina vaginante. Costa única ou ausente, percurrente ou excurrente, estreita, secção transversal com camada de estereídios distinta, ápice do filídio apiculado ou acuminado, margem do filídio plana, inteira ou denticulada, não bordeada ou bordeada (ca. 10-15:1 compr.), células da lâmina longo-hexagonais ou quadrático-irregulares, longitudinalmente muito 


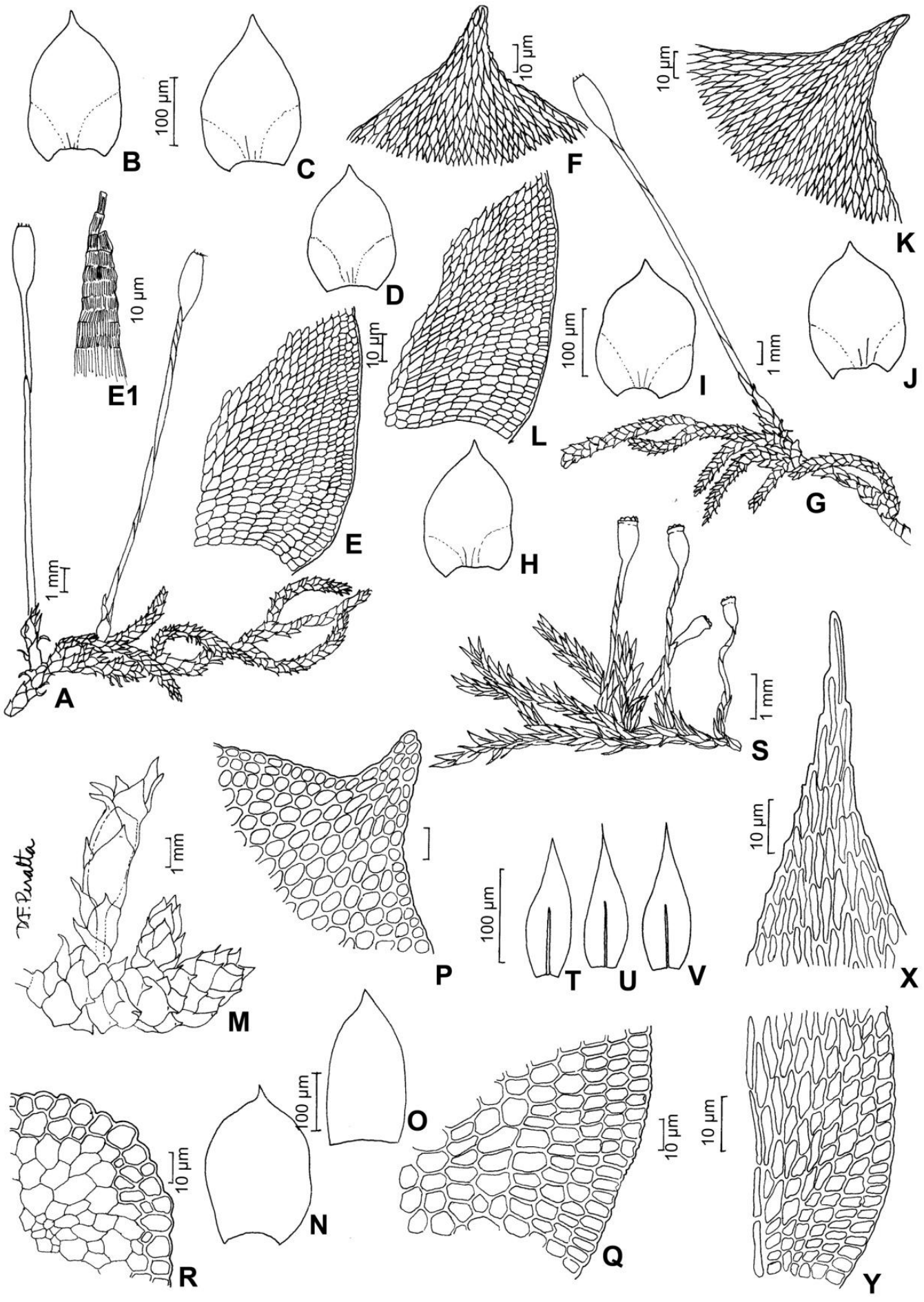

Fig. 13. Erythrodontium longisetum (Hook.) Paris. A. aspecto do gametófito. B-D. filídios. E. células da base do filídio. F. células do ápice do filídio. Erythrodontium squarrosum (Hampe) Paris. G. aspecto do gametófito. H-J. filídios. K. células do ápice do filídio. L. células da base do filídio. Erpodium coronatum (Hook. \& Wilson) Mitt. M. aspecto do gametófito. N-O. filídios. P. células do ápice do filídio. Q. células da base do filídio. R. secção transversal do caulídio. Fabronia ciliaris (Brid.) Brid. var. ciliaris. S. aspecto do gametófito. T-V. filídios. X. células do ápice do filídio. Y. células da base do filídio (A-F. O. Yano \& Wanderley 10673; G-L. Vital 7593; M-R. O. Yano 541; S-Y. O. Yano \& Wanderley 10723). 
Flora da Serra do Cipó, Minas Gerais: Briófitas (Anthocerotophyta, Bryophyta e Marchantiophyta)

alongadas ou pouco alongadas ou isodiamétricas, lisas ou mamilosas ou papilosas, parede celular espessada ou delgada, reta, células da base do filídio mais claras, alongadas porém não infladas. Reprodução vegetativa por gemas, no caulídio entre os filídios. Filídios periqueciais diferenciados. Seta curta ou longa, reta. Cápsula exserta ou imersa, ereta, simétrica, urna ovóide ou sub-cilíndrica, rômbica, superfície lisa quando seca. Opérculo rostrado. Peristômio simples. Caliptra glabra.

Chave para as espécies

1. Margem do filídio com bordo nítido (limbídio).

2. Células dos filídios alongadas; costa $1 / 2$ a $3 / 4$ do compr. do filídio

1.7. F. scariosus

2'. Células dos filídios isodiamétricas; costa percurrente.

1.10. F. zollingeri

1'. Margem do filídio sem limbídio ou com limbídio restrito a lâmina vaginante.

3. Bordo (limbídio) restrito a lâmina vaginante.

4. Limbídio marginal.

5. Células pluripapilosas

1.3. F. intromarginatus

5'. Células unipapilosas 1.9. F. submarginatus

4'. Limbídio intramarginal.

6. Células da lâmina pluripapilosas; gametófitos medianos 1.1. F. elegans

6'. Células da lâmina unipapilosas; gametófitos pequenos a delicados

3'. Bordo (limbídio) ausente.

7. Margem inteira.

7'. Margem denticulada a crenulada.

8, Margem crenulada

8'. Margem denticulada.

9. Gametófitos pequenos a delicados; células obscuras; papila grande, ramificada

9'. Gametófitos medianos; células pelúcidas (translúcidas); papila simples

2. F. hornschuchii

1.6. F. pellucidus

1.8. F. spurio-limbatus

1.4. F. lagenarius 1.5. F. pallidinervis

1.1. Fissidens elegans Brid., Musc. Recent. Suppl. 1: 167. 1806.

Fig. 14 G-M

Gametófitos medianos. Filídios distantes no caulídio, lanceolados, células dos filídios isodiamétricas, obscuras, pluripapilosas, papilas simples, margem denticulada, bordo (limbídio) restrito a lâmina vaginante, intramarginal, costa subpercurrente.

Material examinado: Minas Gerais, Santana do Riacho, Serra da Bandeirinha, O. Yano \& Wanderley 10742 10847, 10751; 10828 p.p.; 10897; 10905 (SP220436; SP220540; SP220445; SP220521; SP220590; SP220598).

Associada a Fissidens hornschuchii Mont. Ocorre nos estados de AC, AM, ES, FN, GO, MG, MS, MT, PA, PB, PE, PI, PR, RJ, RO, RR, RS, SC, SP e TO. Na Serra do Cipó, cresce em solo arenoso, base de tronco vivo e caído.

1.2. Fissidens hornschuchii Mont., Ann. Sci. Nat. Bot. sér. 2, 40: 342. 1840.

Fig. $14 \mathrm{~N}-\mathrm{T}$

Gametófitos pequenos a delicados. Filídios distantes no caulídio, lanceolados, células dos filídios isodiamétricas, obscuras, unipapilosas, simples, margem denticulada, bordo (limbídio) restrito a lâmina vaginante, intramarginal, costa subpercurrente.

Material examinado: Minas Gerais, Santana do Riacho, Serra da Bandeirinha, O. Yano \& Wanderley 10806 p.p., 10828 p.p., 10849 p.p. (SP220499; SP220521; SP220533)

Associada a Fissidens elegans Brid., $F$. scariosus Mitt. e F. submarginatus (Hampe) A. Jaeger. Ocorre nos estados de AL, AM, CE, ES, FN, GO, MG, MT, PA, PE, PR, RJ, RS, SC e SP. Na Serra do Cipó, cresce em solo e termiteiro.

1.3. Fissidens intromarginatus (Hampe) A. Jaeger, Enum. Fissident.: 14. 1869.

Fig. 14 U-A1

Gametófitos medianos. Filídios distantes no caulídio, lanceolados, células dos filídios isodiamétricas, obscuras, unipapilosas, simples, margem denticulada, bordo (limbídio) restrito a lâmina vaginante, marginal, costa percurrente.

Material examinado: Minas Gerais, Santana do Riacho, Serra da Bandeirinha, O. Yano \& Wanderley 10900 (SP220593).

Ocorre nos estados de AC, BA, CE, ES, GO, MG, MS, MT, PA, PB, PR, RJ, RO, RS, SC e SP. Na Serra do Cipó, cresce em tronco vivo. 


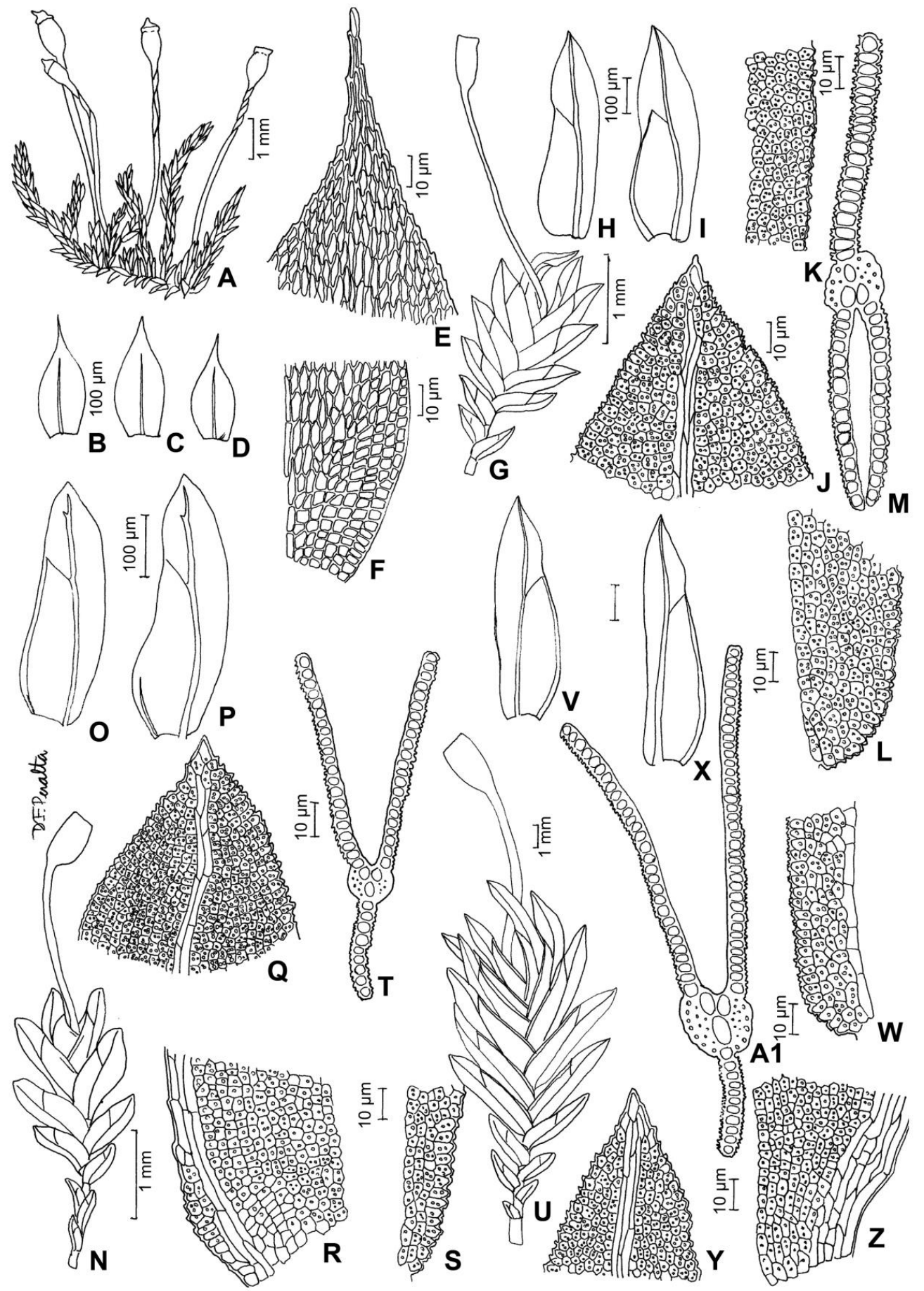

Fig. 14. Fabronia ciliaris var. polycarpa (Hook.) W.R. Buck. A. aspecto do gametófito. B-D. filídios. E. células do ápice do filídio. F. células da base do filídio. Fissidens elegans Brid. G. aspecto do gametófito. H-I. filídios. J. células do ápice do filídio. K. células da margem do filídio. L. células da margem da lâmina dorsal. M. secção transversal do filídio na região da lâmina vaginante. Fissidens hornschuchii Mont. N. aspecto do gametófito. O-P. filídios. Q. células do ápice do filídio. R. células da base na lâmina vaginante. S. células da margem da lâmina dorsal. T. secção transversal do filídio na região da lâmina vaginante. Fissidens intromarginatus (Hampe) A. Jaeger. U. aspecto do gametófito. V-X. filídios. Y. células do ápice do filídio. Z. células da base da lâmina vaginante do filídio. W. células da margem da lâmina dorsal. A1. secção transversal do filídio na região da lâmina vaginante (A-F. O. Yano \& Wanderley 10712; G-M. O. Yano \& Wanderley 10742; N-T. O. Yano \& Wanderley 10806 p.p.; U-A1. O. Yano \& Wanderley 10900). 
Flora da Serra do Cipó, Minas Gerais: Briófitas (Anthocerotophyta, Bryophyta e Marchantiophyta)

1.4. Fissidens lagenarius Mitt. var. lagenarius, J. Linn. Soc. Bot. 10: 184. 1858.

Fig. $15 \mathrm{~A}-\mathrm{G}$

Gametófitos pequenos a delicados. Filídios distantes no caulídio, lanceolados, células dos filídios isodiamétricas, obscuras, unipapilosas, grande, ramificada, margem denticulada, bordo (limbídio) ausente, costa percurrente.

Material examinado: Minas Gerais, Conceição do Mato Dentro, O. Yano 500 (SP135464).

Ocorre nos estados do AM, ES, GO, PA, PE, RJ, RO, RS, SC e SP. Na Serra do Cipó, cresce em tronco de árvore viva que fica temporariamente submersa. Esta espécie é característica de locais encharcados.

1.5. Fissidens pallidinervis Mitt., J. Linn. Soc. Bot. 12: 592. 1869.

Fig. $15 \mathrm{H}-\mathrm{N}$

Gametófitos medianos. Filídios distantes no caulídio, lanceolados, células dos filídios isodiamétricas, pelúcidas (translúcidas), unipapilosas, simples, margem denticulada, bordo (limbídio) ausente, marginal, costa percurrente.

Material examinado: Minas Gerais, Santana do Riacho, Serra da Bandeirinha, O. Yano \& Wanderley 10793 p.p. (SP220486).

Associada a Cephaloziella granatensis (Jack) Fulford. Ocorre nos estados de AC, AM, BA, CE, FN, GO, MG, MS, MT, PA, PE, PI, PR, RJ, RO, RR, SC e SP. Na Serra do Cipó, cresce em sobre termiteiro.

1.6. Fissidens pellucidus Hornsch., Linnaea 15: 146. 1841.

Fig. $15 \mathrm{O}-\mathrm{U}$

Gametófitos pequenos a delicados. Filídios distantes no caulídio, lanceolados, células dos filídios isodiamétricas, pelúcidas (translúcidas), lisas, ausente, margem inteira, bordo (limbídio) ausente, costa percurrente.

Material examinado: Minas Gerais, Santana do Riacho, Câmara 1902 p.p. (SP419644); Dias Neto 110 p.p., 130, 158 p.p. (SP419747; SP419762; SP419780).

Associada a Fissidens scariosus Mitt., Kurzia capillaris (Sw.) Grolle e Pallavicinia lyellii (Hook.) S.F. Gray. Ocorre nos estados de AM, BA, CE, DF, GO, MG, MT, PA, PE, PR, RJ, RO, RR, RS, SC, SP e TO. $\mathrm{Na}$ Serra do Cipó, cresce em solo. Esta espécie é facilmente identificada pelas células grandes e translúcidas.

1.7. Fissidens scariosus Mitt., J. Linn. Soc. Bot. 12: 599. 1869.

Fig. $15 \mathrm{~V}-\mathrm{B} 1$

Gametófitos pequenos a delicados. Filídios dispostos em leque, lanceolados, células dos filídios alongadas, pelúcidas (translúcidas), lisas, ausente, margem inteira, bordo (limbídio) presente (mesmo que incompleto), ausente, costa 1/2 a 3/4 do compr.

Material examinado: Minas Gerais, Santana do Riacho, Serra da Bandeirinha, O. Yano \& Wanderley 10806 p.p. (SP220499); Dias Neto 158p.p. (SP419780).

Associada a Fissidens hornschuchii Mont. e F. pellucidus Hornsch. Ocorre nos estados de AM, BA, ES, MG, PA, PE, PR, RJ, RO, RR, RS, SP e SC. Na Serra do Cipó, cresce em solo argiloso. Esta espécie é facilmente identificada pelas células longo-hexagonais e translúcidas.

1.8. Fissidens spurio-limbatus Broth., Hedwigia 34: 121. 1895.

Fig. 16 A-G

Gametófitos medianos. Filídios distantes no caulídio, lanceolados, células dos filídios isodiamétricas, pelúcidas (translúcidas), unipapilosas, simples, margem crenulada, bordo (limbídio) ausente, marginal, costa percurrente

Material examinado: Minas Gerais, Santana do Riacho, O. Yano \& Wanderley 10931 (SP220624).

Ocorre nos estados do BA, ES, DF, GO, PR e SP. Na Serra do Cipó, cresce em solo arenoso.

1.9. Fissidens submarginatus Bruch in $\mathrm{C}$. Krauss, Flora 29: 133. 1849.

Fig. $16 \mathrm{~N}-\mathrm{N}$

Gametófitos pequenos a delicados. Filídios distantes no caulídio, lanceolados, células dos filídios isodiamétricas, pelúcidas (translúcidas), unipapilosas, simples, margem denticulada, bordo (limbídio) restrito a lâmina vaginante, ausente, costa percurrente.

Material examinado: Minas Gerais, Santana do Riacho, Serra da Bandeirinha, O. Yano \& Wanderley 10849 p.p. (SP220533); Dias Neto 99 (SP419737).

Associada a Fissidens hornschuchii Mont. Ocorre nos estados de AC, AM, BA, CE, DF, ES, FN, GO, MA, MS, MT, PA, PB, PE, PI, RJ, RO, RN, RS, SC, SP e TO. Na Serra do Cipó, cresce em solo e termiteiro. 


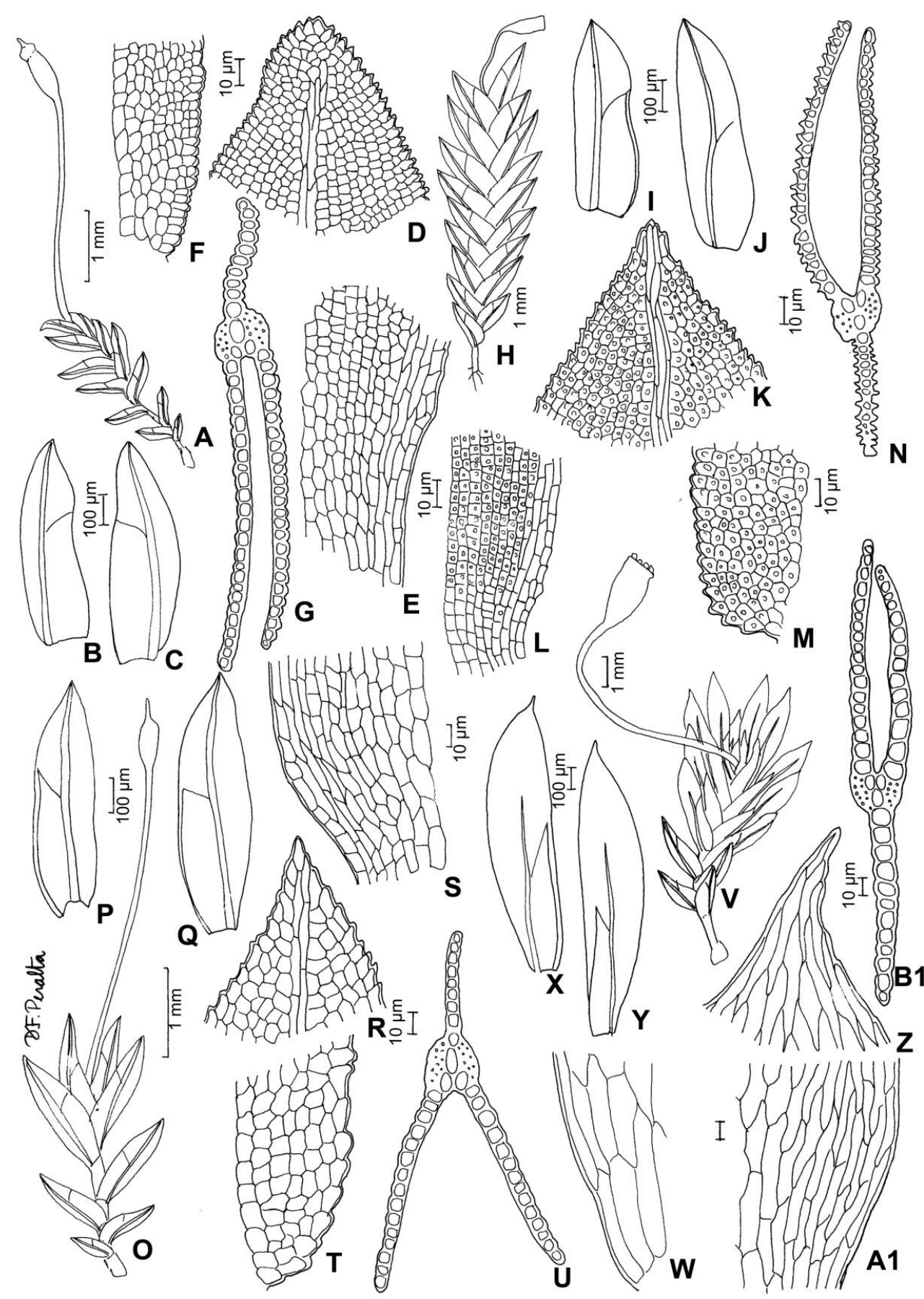

Fig. 15. Fissidens lagenarius Mitt. var. lagenarius. A. aspecto do gametófito. B-C. filídios. D. células do ápice do filídio. E. células da base da lâmina vaginante do filídio. F. células da margem da lâmina dorsal. G. secção transversal do filídio na região da lâmina vaginante. Fissidens pallidinervis Mitt. H. aspecto do gametófito. I-J. filídios. K. células do ápice do filídio. L. células da base da Lamina vaginante do filídio. M. células da margem da lâmina dorsal. N. secção transversal do filídio na região da lâmina vaginante. Fissidens pellucidus Hornsch. O. aspecto do gametófito. P-Q. filídios. R. células do ápice do filídio. S. células da base da lâmina vaginante do filídio. T. células da margem da lâmina dorsal. U. secção transversal do filídio na região da lâmina vaginante. Fissidens scariosus Mitt. V. aspecto do gametófito. X-Y. filídios. z. células do ápice do filídio. W. células da base da lâmina do filídio. A1. células da margem da lâmina dorsal. B1. secção transversal do filídio na região da lâmina vaginante (A-G. O. Yano 500; H-N. O. Yano \& Wanderley 10793 p.p.; O-U. Câmara 1902 p.p.; V-B1. O. Yano \& Wanderley 10806 p.p.). 
1.10. Fissidens zollingeri Mont., Ann. Sci. Nat. Bot. sér. 3, 4: 114. 1845.

Fig. 16 O-T

Gametófitos pequenos a delicados. Filídios dispostos em leque, lanceolados, células dos filídios isodiamétricas, pelúcidas (translúcidas), lisas, ausente, margem inteira, bordo (limbídio) presente (mesmo que incompleto), ausente, costa percurrente.

Material examinado: Minas Gerais, Santana do Riacho, O. Yano \& Wanderley 10927 (SP220620).

Ocorre nos estados do AC, AL, AM, AP, BA, CE, DF, ES, FN, GO, MA, MG, MS, MT, PA, PB, PE, PI, PR, RJ, RO, RR, RS, SC, SP e TO. Na Serra do Cipó, cresce em solo.

\section{Funariaceae}

É uma família amplamente distribuída mas pouco coletada no Brasil, caracterizada principalmente pela costa simples, margem não diferenciada e células longo-hexagonais. Ocorre principalmente como terrestre e está sempre associada a locais ventilados e expostos diretamente. Para a identificação das espécies é necessário análise do esporófito. No Brasil ocorrem três gêneros e 27 espécies; na Serra do Cipó ocorrem os gêneros Entosthodon e Funaria, cada um com uma espécie.

Bibliografia básica - Gradstein et al. (2001); Sharp et al. (1994); Yano \& Peralta (2009).

Chave para os gêneros

1. Cápsula inclinada e assimétrica, dentes do peristômio grandes e espiralmente torcidos

2. Funaria

1'. Cápsula ereta e simétrica, dentes do peristômio reduzidos 1. Entosthodon

\section{Entosthodon Schwägr.}

Gametófitos acrocárpicos, pequenos, delicados, gregários ou formando tufos. Caulídios primários eretos, poucos rizóides, ramos secundários ausentes ou raros. Filídios ligulados ou lanceolados, planos, espiralados, quando secos crispados. Costa única, atingindo até $1 / 2$ ou $3 / 4$ compr. do filídio, estreita, secção transversal com camada de estereídios distinta, ápice do filídio apiculado ou agudo, margem do filídio plana, denticulada, não bordeada ou bordeada (ca. 10-15:1 compr.), células da lâmina longohexagonais, pouco alongadas, lisas, parede celular delgada, reta, células da base do filídio mais claras, alongadas porém não infladas. Seta longa, reta, torcida. Cápsula ereta, simétrica, urna piriforme ou ovóide, rômbica. Superfície quando seca estriada, ânulo presente. Opérculo cônico. Peristômio ausente ou presente, único ou duplo. Caliptra glabra.

1.1. Entosthodon bonplandii (Hook.) Mitt., J. Linn. Soc. Bot. 12: 245. 1869.

Fig. $16 \mathrm{U}-\mathrm{Z}$

Gametófitos pequenos, delicados, formando tufos. Filídios ligulados ou lanceolados, quando secos crispados. Costa única, 1/2 ou 3/4 compr. do filídio, estreita, margem denticulada, não bordeada (ca. 1015:1 compr.), células da lâmina longo-hexagonais, pouco alongadas, lisas, parede celular delgada, reta, células da base do filídio mais claras, alongadas porém não infladas. Seta longa, reta. Cápsula ereta, simétrica, urna ovóide, rômbica. Opérculo cônico. Peristômio duplo. Caliptra glabra.

Material examinado: Minas Gerais, Conceição do Mato Dentro, O. Yano 494 (SP135461).

Ocorre nos estados de ES, GO, MG, PI, RJ, RS, SC e SP. Na Serra do Cipó, cresce em solo. Os gametófitos desta espécie apresentam aspecto brilhante quando secos, o que os diferencia das espécies de Bryaceae que é a família morfologicamente mais semelhante.

\section{Funaria Hedw.}

Gametófitos acrocárpicos, medianos, formando tufos. Caulídios primários eretos, poucos rizóides, ramos secundários ausentes ou raros. Filídios lanceolados, planos, espiralados, quando secos crispados. Costa única, percurrente, estreita, secção transversal com camada de estereídios distinta, ápice do filídio agudo, margem do filídio plana, denticulada, não bordeada, células da lâmina longo-hexagonais, pouco alongadas, lisas, parede celular delgada, reta, células da base do filídio mais claras, alongadas porém não infladas. Seta longa, reta, torcida. Cápsula ereta, pêndula, assimétrica, urna piriforme, rômbica. Superfície quando seca estriada, ânulo presente. Opérculo cônico. Peristômio duplo. Caliptra glabra. 


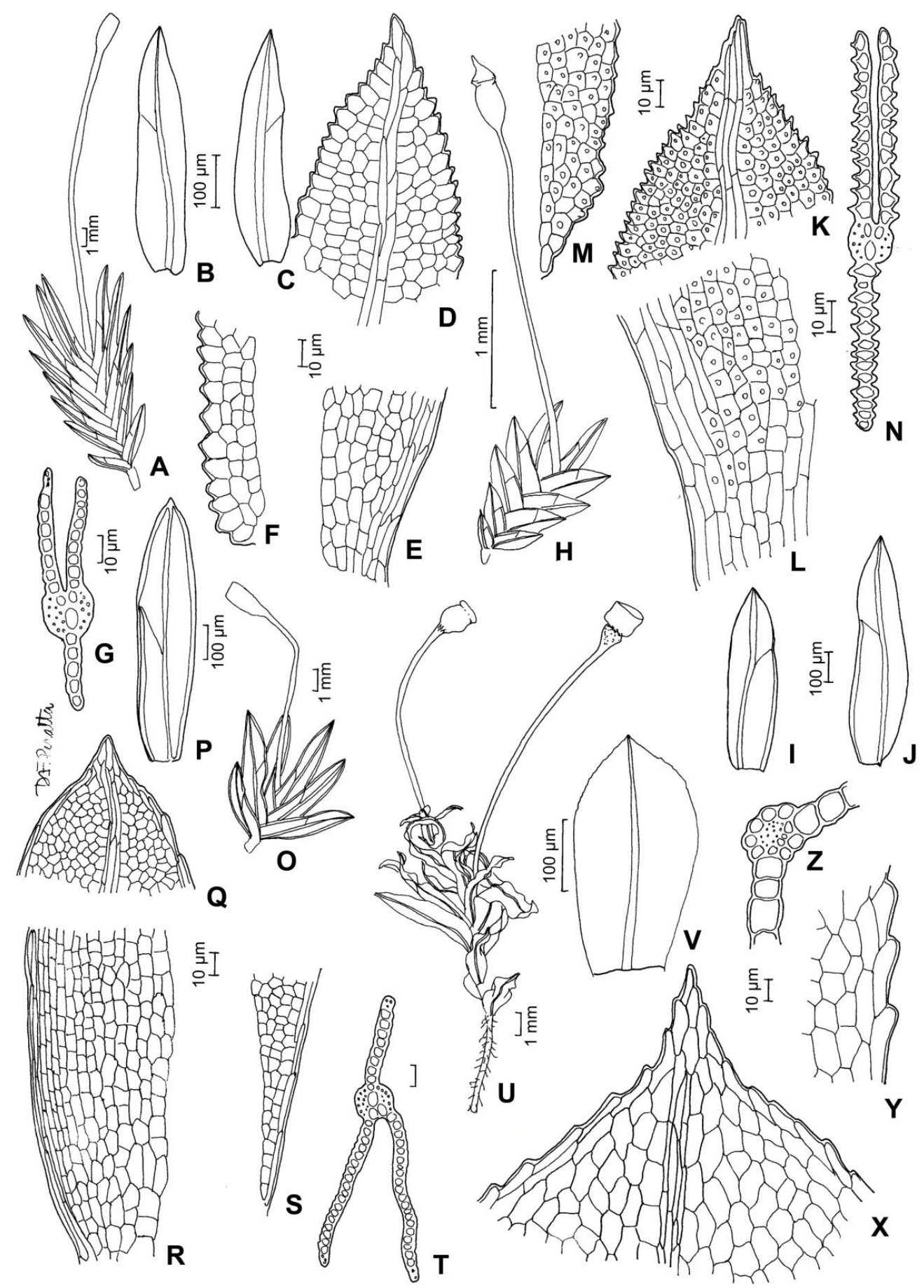

Fig. 16. Fissidens spurio-limbatus Broth. A. aspecto do gametófito. B-C. filídios. D. células do ápice do filídio. E. células da base da lâmina vaginante do filídio. F. células da margem da lâmina dorsal. G. secção transversal do filídio na região da lâmina vaginante. Fissidens submarginatus Bruch. H. aspecto do gametófito. I-J. filídios. K. células do ápice do filídio. L. células da base da lâmina vaginante do filídio. M. células da margem da lâmina dorsal. N. secção transversal do filídio na região da lâmina vaginante. Fissidens zollingeri Mont. O. aspecto do gametófito. P. filídio. Q. células do ápice do filídio. R. células da base da lâmina vaginante do filídio. S. células da margem da lâmina dorsal. T. secção transversal do filídio na região da lâmina vaginante. Entosthodon bonplandii (Hook.) Mitt. U. aspecto do gametófito. V. filídio. X. células do ápice do filídio. Y. células da margem do filídio. Z. secção transversal do filídio na região mediana (A-G. O. Yano \& Wanderley 10931; H-N. O. Yano \& Wanderley 10849 p.p.; O-T. O. Yano \& Wanderley 10927; U-Z. O. Yano 494). 
Flora da Serra do Cipó, Minas Gerais: Briófitas (Anthocerotophyta, Bryophyta e Marchantiophyta)

2.1. Funaria hygrometrica Hedw., Spec. Musc. Frond.: 172. 1801.

Fig. 16a A-H

Gametófitos medianos, formando tufos. Filídios lanceolados, quando secos crispados. Costa única, percurrente, estreita, margem denticulada, não bordeado (ca. 10-15:1 compr.), células da lâmina longo-hexagonais, pouco alongadas, lisas, parede celular delgada, reta, células da base do filídio mais claras, alongadas porém não infladas. Seta longa, reta. Cápsula pêndula, assimétrica, urna piriforme, rômbica. Opérculo cônico. Peristômio duplo. Caliptra glabra.

Material examinado: Minas Gerais, Santana do Riacho, Pirani et al. 5707 (SP432339, SPF).

Ocorre nos estados de BA, DF, GO, MG, MT, PA, PE, PR, RJ, RS, SC e SP. Na Serra do Cipó, cresce em solo. Esta espécie cresce geralmente no solo úmido com grande quantidade de calcário, isto é, em locais com restos de construção ou em solo queimado.

\section{Helicophyllaceae}

É uma família amplamente distribuída no Brasil, caracterizada principalmente pelo aspecto contorcido dos filídios quando secos e as célula da lâmina mamilosas. Ocorre principalmente como corticícola e rupícola e está sempre associada a locais ventilados e expostos diretamente. A família é monotípica com apenas a espécie Helicophyllum torquatum.

Bibliografia básica - Gradstein et al. (2001); Sharp et al. (1994); Yano (1979); Yano \& Costa (2000); Yano \& Peralta (2009).

\section{Helicophyllum Brid.}

Gametófitos acrocárpicos, medianos, formando tapetes. Caulídios primários prostrados, tomentosos, ramos secundários prostrados. Filídios ligulados. Filídios de dois formatos laterais e dorsais, planos, aplainados, quando secos involutos. Costa única, percurrente, estreita, ápice do filídio obtuso ou truncado, margem do filídio plana, inteira, bordeada, células da lâmina circulares ou quadrático-irregulares, isodiamétricas, mamilosas, parede celular delgada, reta, células da base do filídio iguais as da lâmina, filídios periqueciais diferenciados. Seta curta, reta. Cápsula imersa, ereta, simétrica, urna sub-cilíndrica, rômbica, superfície lisa quando seca. Opérculo cônico. Peristômio ausente. Caliptra glabra.

\subsection{Helicophyllum torquatum (Hook.) Brid.,} Bryol. Univ. 2: 771.1827.

Fig. 17 A-J

Gametófitos medianos, formando tapetes. Caulídios primários prostrados, tomentosos. Filídios de dois formatos laterais e dorsal. Costa única, percurrente, estreita, ápice do filídio obtuso ou truncado, margens inteira, bordeada, células da lâmina circulares ou quadrático-irregulares, mamilosas, filídios periqueciais diferenciados. Seta curta, reta. Cápsula imersa, ereta, simétrica, urna sub-cilíndrica, rômbica, superfície lisa quando seca. Opérculo cônico. Peristômio ausente. Caliptra glabra.

Material examinado: Minas Gerais, Morro do Pilar, Vital 7592 (SP136557); Santana do Riacho, Cachoeira Farofa, O. Yano \& Wanderley 10674, 10917, 10923, 10922 p.p., 10925 (SP220369; SP220610; SP220616; SP220615; SP220618); Serra da Bandeirinha, O. Yano \& Wanderley 10762 (SP220456).

Associada a Erpodium coronatum (Hook. \& Wilson) Mitt. Ocorre nos estados de AL, AM, BA, CE, DF, ES, GO, MG, MS, MT, PA, PB, PE, PI, PR, RJ, RS, SC, SP e TO. Na Serra do Cipó, cresce em tronco vivo e rocha. É uma espécie facilmente identificada pelo aspecto contorcido dos filídios. 


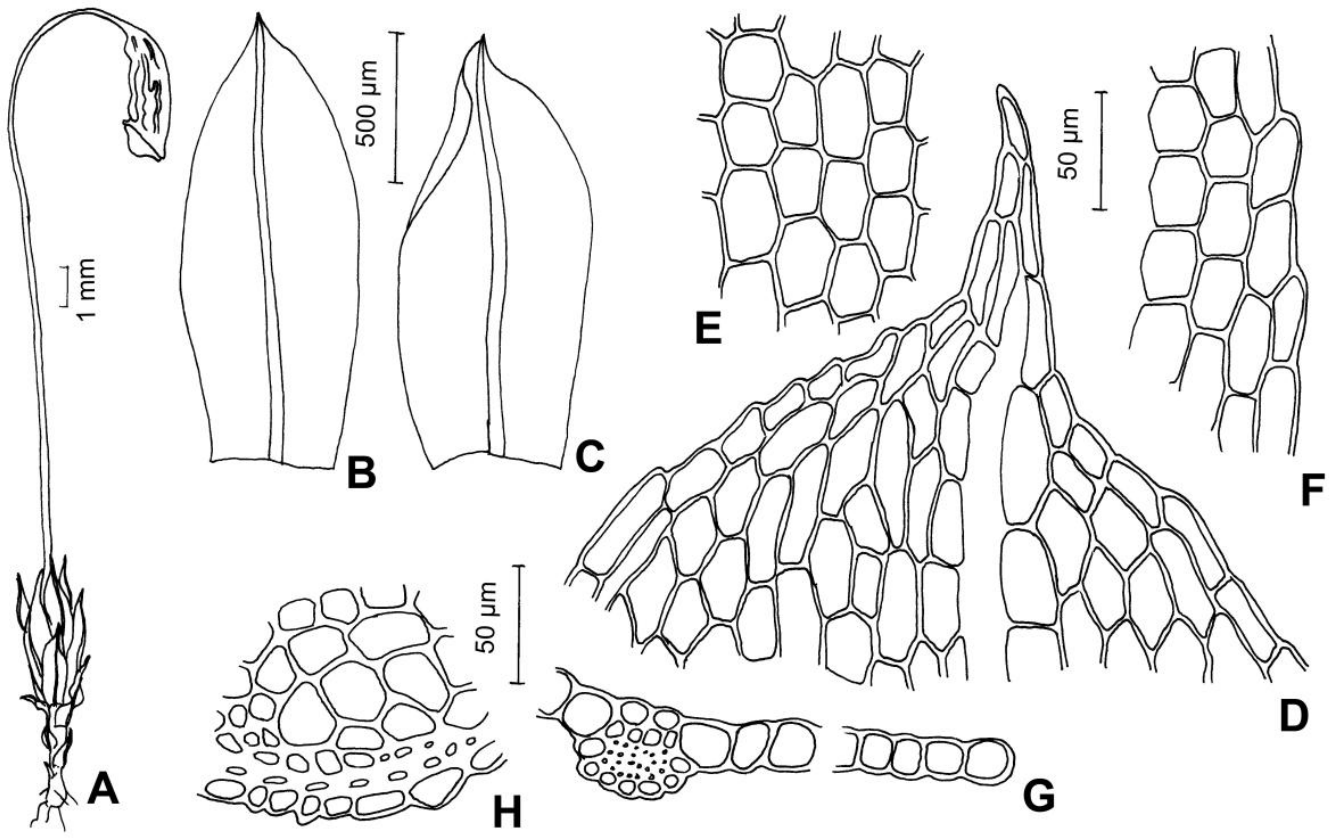

Fig. 16a. Funaria hygrometrica Hedw. A. aspecto do gametófito. B-C. filídios. D. detalhe do ápice do filídio. E. células da lâmina do filídio. F. células da margem do filídio. G. secção transversal da costa. H. detalhe secção transversal do caulídio (A-H. Pirani et al. 5707).

\section{Hypnaceae}

Gametófitos pleurocárpicos, pequenos e delicados ou medianos, formando tapetes. Caulídios primários prostrados, ramos secundários ascendentes ou prostrados, paráfilos lisas. Filídios lanceolados ou ovados, filídios em alguns gêneros diferenciados em laterais e ventral, assimétricos ou bilateralmente simétricos, planos, côncavos ou secundos, aplainados ou espiralados, ápice do filídio acuminado ou agudo, margens planas, denticulada, não bordeadas. Costa dupla e curta, estreita. Células da lâmina longohexagonais ou lineares, lisas ou papilosas nos ângulos distais, parede celular delgada, reta, região alar quadrático irregular. Dióicos, monóicos ou autóicos. Seta longa, reta, marrom-dourada, rugosa ou lisa.
Cápsula pêndula ou inclinada, assimétrica, urna ovóide ou subcilíndrica, rômbica. Peristômio duplo. Caliptra glabra, não plicada.

É uma família amplamente distribuída no Brasil, caracterizada principalmente pela costa curta e dupla e as pseudoparáfilos lisas. Ocorre principalmente como terrícola e saxícola e está sempre associada úmidos e protegidos. Para a identificação das espécies é necessário análise das pseudoparáfilos e morfologia das células da lâmina dos filídios. No Brasil ocorrem 16 gêneros e 87 espécies; na Serra do Cipó ocorrem quatro gêneros e seis espécies.

Bibliografia básica - Gradstein et al. (2001); Ireland \& Buck (2009); Sharp et al. (1994); Yano \& Peralta (2009). 


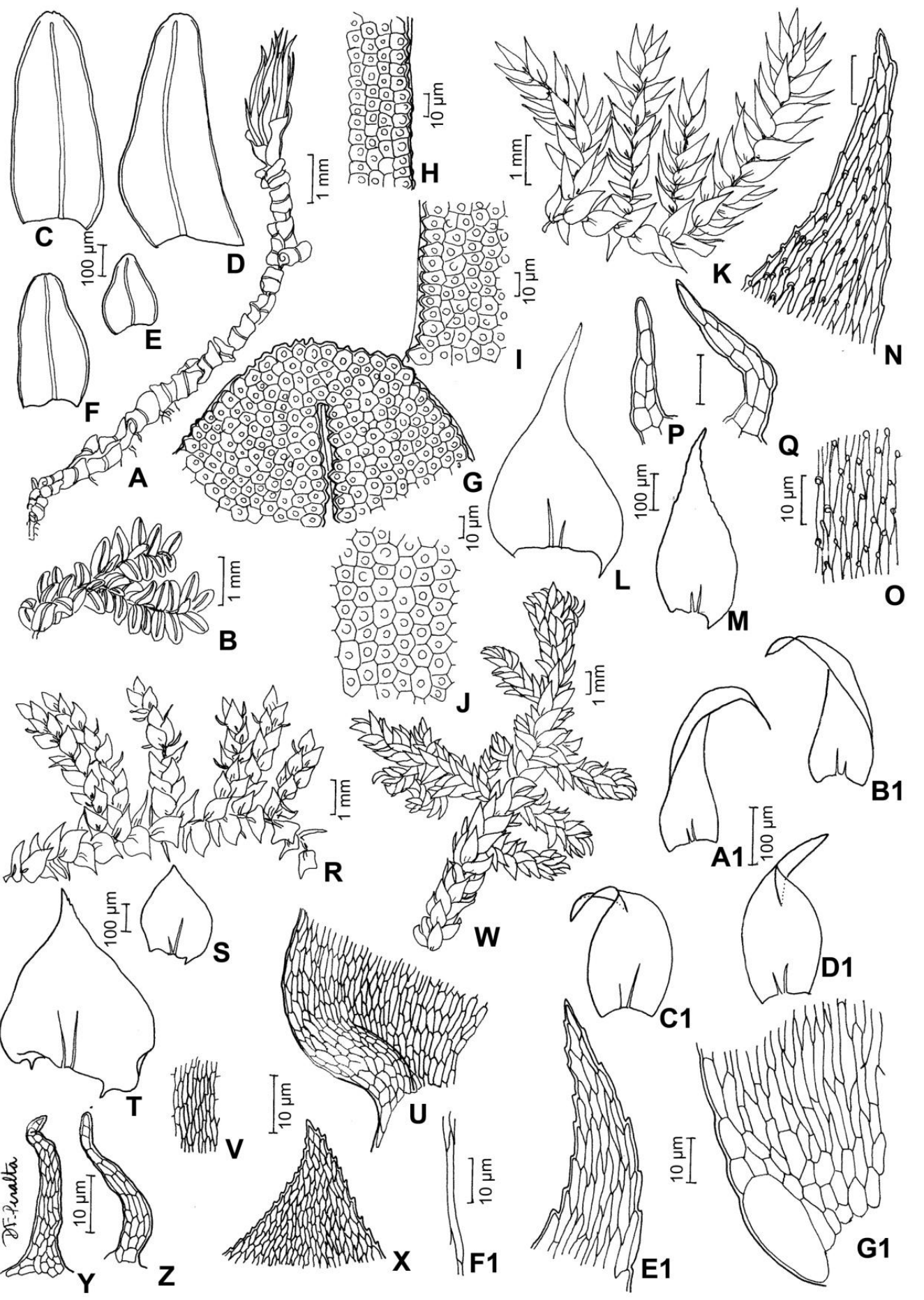

Fig. 17. Helicophyllum torquatum (Hook.) Brid. A-B. aspecto do gametófito. C-D. filídios laterais. E-F. filídios dorsais. G. células do ápice do filídio. H. células da margem do filídio. I. células da base do filídio. J. células da lâmina do filídio. Chryso-hypnum diminutivum (Hampe) W.R. Buck. K. aspecto do gametófito. L-M. filídios. N. células do ápice do filídio. O. células da lâmina do filídio. P-Q. pseudoparáfilos. Chryso-hypnum elegantulum (Hook.) Hampe. R. aspecto do gametófito. S. filídio dos ramos. T. filídio do caulídio. U. base do filídio. V. células da lâmina do filídio. X. células do ápice do filídio. Y-Z. pseudoparáfilos. Ectropothecium leptochaeton (Schwägr.) W.R. Buck. W. aspecto do gametófito. A1-D1. filídios. E1. células do ápice do filídio. F1. células da lâmina do filídio. G1. células da base do filídio (A-J. Vital 7592; K-Q. Vital 7577; R-Z. O. Yano \& Wanderley 10810; W-G1. O. Yano 486). 
1. Caulídios primários prostrados e ramificações ascendentes, células da lâmina com papilas nos ângulos distais

1. Chryso-hypnum

1'. Caulídios e ramificações prostrados, células da lâmina sem papilas.

2. Filídios dimórficos, diferenciados em ventrais estreito-lanceolados e dorsais oblongos

4. Vesicularia

2'. Filídios monomórficos, lanceolado-acuminados, células lineares.

3. Gametófitos robustos, pseudoparáfilos folhosos

2. Ectropothecium

3'. Gametófitos delicados, pseudoparáfilos filiformes 3. Isopterygium

\section{Chryso-hypnum (Hampe) Hampe}

Gametófitos medianos, formando tapetes. Caulídios primários prostrados, poucos rizóides, ramos secundários ascendentes, pseudoparáfilos lisos. Filídios lanceolado ou ovados, marcadamente assimétricos, planos, côncavos ou secundos, aplainados ou espiralados quando secos crispados ou planos. Costa dupla, curta, ca. $3 / 10$ a 5/10 do compr., estreita, ápice do filídio acuminado ou agudo, margem do filídio plana, denticulada, não bordeada, células da lâmina longo-hexagonais ou lineares, longitudinalmente muito alongadas, papilosas, nos ângulos distais, parede celular delgada, reta, células da base do filídio quadrático-irregulares. Seta longa, reta. Cápsula exserta, pêndula ou inclinada, assimétrica, urna ovóide ou subcilíndrica, rômbica, superfície lisa quando seca, ânulo presente. Opérculo rostrado, peristômio duplo. Caliptra glabra.

Chave para as espécies

1. Filídios lanceolados, pseudoparáfilos filamentosas

1.1. C. diminutivum

1'. Filídios oblongo-lanceolados, pseudoparáfilos folhosos 1.2. C. elegantulum

1.1. Chryso-hypnum diminutivum (Hampe) W.R. Buck, Brittonia 36: 182. 1984.

Fig. $17 \mathrm{~K}-\mathrm{Q}$

Gametófitos medianos, formando tapetes. Caulídios primários prostrados, ramos secundários ascendentes, pseudoparáfilos lisos, filamentosas. Filídios lanceolados. Costa dupla, curta, ca. 3/10 a $5 / 10$ do compr., estreita, ápice do filídio acuminado, margem do filídio denticulada, células da lâmina longohexagonais ou lineares, longitudinalmente muito alongadas, papilosas nos ângulos distais, parede celular delgada, reta, células da base do filídio quadrático-irregulares. Seta longa, reta. Cápsula exserta, pêndula ou inclinada, assimétrica, urna ovóide ou sub-cilíndrica, rômbica, superfície lisa quando seca, ânulo presente. Opérculo rostrado, peristômio duplo. Caliptra glabra.

Material examinado: Minas Gerais, Conceição do Mato Dentro, Vital 7577 (SP136548).

Ocorre nos estados de AC, AL, AM, AP, BA, DF, ES, GO, MA, MG, MT, MS, PA, PE, RJ, PR, RR, RS, SC e SP. Na Serra do Cipó, cresce em solo.
1.2. Chryso-hypnum elegantulum (Hook.) Hampe, Vidensk. Meddel. Dansk Naturhist. For. Kjøbenhavn 2: 286. 1879.

Fig. 17 R-Z

Gametófitos medianos, formando tapetes. Caulídios primários prostrados, ramos secundários ascendentes, pseudoparáfilos lisos, folhosos. Filídios oblongo-lanceolados. Costa dupla, curta, ca. 3/10 a 5/10 do compr., estreita, ápice do filídio acuminado, margem do filídio denticulada, células da lâmina longohexagonais ou lineares, longitudinalmente muito alongadas, papilosas nos ângulos distais, parede celular delgada, reta, células da base do filídio quadrático-irregulares. Seta longa, reta. Cápsula exserta, pêndula ou inclinada, assimétrica, urna ovóide ou sub-cilíndrica, rômbica, superfície lisa quando seca, ânulo presente. Opérculo rostrado, peristômio duplo. Caliptra glabra.

Material examinado: Minas Gerais, Santana do Riacho, O. Yano \& Wanderley 10810 (SP220503).

Ocorre nos estados de AM, BA, ES, DF, GO, MG, MS, MT, PR, RJ, RS, SC e SP. Na Serra do Cipó, cresce em tronco vivo. 
Flora da Serra do Cipó, Minas Gerais: Briófitas (Anthocerotophyta, Bryophyta e Marchantiophyta)

\section{Ectropothecium Mitt.}

Gametófitos medianos, formando tapetes. Caulídios primários prostrados, poucos rizóides, ramos secundários ascendentes, pseudoparáfilos lisos, folhosos. Filídios lanceolado ou ovados, marcadamente assimétricos ou planos, côncavos ou secundos, aplainados ou espiralados, quando secos crispados ou planos. Costa dupla, curta, ca. 1/10 a 1/20 do compr., estreita, ápice do filídio acuminado ou agudo, margem do filídio plana, denticulada, não bordeada, células da lâmina longo-hexagonais ou lineares, longitudinalmente muito alongadas, lisas, parede celular delgada, reta, células da base do filídio quadrático-irregulares. Seta longa, reta. Cápsula exserta, pêndula ou inclinada, assimétrica, urna ovóide ou sub-cilíndrica, rômbica, superfície lisa quando seca, ânulo presente. Opérculo rostrado, peristômio duplo. Caliptra glabra.

\subsection{Ectropothecium leptochaeton (Schwägr.)} W.R. Buck, Brittonia 35: 311. 1983.

\section{Fig. $17 \mathrm{~W}-\mathrm{G} 1$}

Gametófitos medianos, formando tapetes. Caulídios primários prostrados, ramos secundários ascendentes, pseudoparáfilos lisos, folhosos. Filídios lanceolados, marcadamente assimétricos, secundos, aplainados. Costa dupla, curta, ca. 1/10 a 1/20 do compr., estreita, ápice do filídio acuminado, células da lâmina longo-hexagonais ou lineares, lisas, parede celular delgada, reta, células da base do filídio quadrático-irregulares. Seta longa, reta. Cápsula exserta, pêndula ou inclinada, assimétrica, urna ovoide ou sub-cilíndrica, rômbica, superfície lisa quando seca, ânulo presente. Opérculo rostrado, peristômio duplo. Caliptra glabra.

Material examinado: Minas Gerais, Conceição do Mato Dentro, O. Yano 486 (SP135455).

Ocorre nos estados de AM, BA, ES, MG, MS, MT, PA, PR, RJ, SC e SP. Na Serra do Cipó, cresce em rocha, submersa em água. Esta espécie é caracterizada e facilmente identificada pelo aspecto falcado dos filídios e a região alar com uma célula grande e inflada.

\section{Isopterygium Mitt.}

Gametófitos pequenos, delicados, formando tapetes. Caulídios primários prostrados, poucos rizóides, ramos secundários ascendentes, pseudoparáfilos filiformes, lisos. Filídios lanceolado ou ovados, marcadamente assimétricos ou planos ou côncavos ou secundos, aplainados ou espiralados, quando secos crispados ou planos. Costa dupla, curta, ca. 1/10 a 1/20 do compr., estreita, ápice do filídio acuminado ou agudo, margem do filídio plana, denticulada, não bordeada, células da lâmina longohexagonais ou lineares, longitudinalmente muito alongadas, lisas, parede celular delgada, reta, células da base do filídio quadrático-irregulares. Seta longa, reta. Cápsula exserta, pêndula ou inclinada, assimétrica, urna ovóide ou sub-cilíndrica, rômbica, superfície lisa quando seca, ânulo presente. Opérculo rostrado, peristômio duplo. Caliptra glabra.

Chave para as espécies

1. Filídios falcado-lanceolados, planos, células alares retangulares

3.1. I. tenerifolium

1 '. Filídios lanceolados, côncavos, células alares quadráticas

3.2. I. tenerum

3.1. Isopterygium tenerifolium Mitt., J. Linn. Soc. Bot. 12: 499. 1869.

Fig. 18 A-H

Gametófitos pequenos, delicados, formando tapetes. Caulídios primários prostrados, secundários ascendentes, pseudoparáfilos filiformes, lisos. Filídios falcado-lanceolados, marcadamente assimétricos, secundos, aplainados, planos quando secos. Costa dupla, curta, ca. $3 / 10$ a 5/10 do compr., estreita, ápice do filídio acuminado, margem do filídio denticulada, células da lâmina longo-hexagonais a lineares, lisas, parede celular delgada, reta, células da base do filídio retangulares. Seta longa, reta. Cápsula exserta, pêndula ou inclinada, assimétrica, urna ovóide ou subcilíndrica, rômbica, superfície lisa quando seca, ânulo presente. Opérculo rostrado, peristômio duplo. Caliptra glabra.
Material examinado: Minas Gerais, Conceição do Mato Dentro, O. Yano 530 (SP135486); Itambé do Mato Dentro, Vital 7615 (SP136570); Santana do Riacho, O. Yano \& Wanderley 10625, 10634, 10665 p.p., 10675, 10678 p.p. (SP220320; SP220329; SP220360; SP220370; SP220373); Dias Neto 162, 233, 234, 253, 254 (SP419783; SP419826; SP419827; SP419836; SP419837).

Associada a Callicostella pallida (Hornsch.) Ångstr., Telaranea nematodes (Gottsche ex Austin) M. Howe. Ocorre nos estados de AL, AM, AP, BA, CE, DF, ES, GO, MG, MT, PA, PB, PE, PR, RJ, RO, RR, RS, SC, SP e TO. Na Serra do Cipó, cresce em rocha, solo e base de tronco. $O$ aspecto falcado dos filídios são característicos desta espécie, comumente encontrada em solo e base de troncos. 


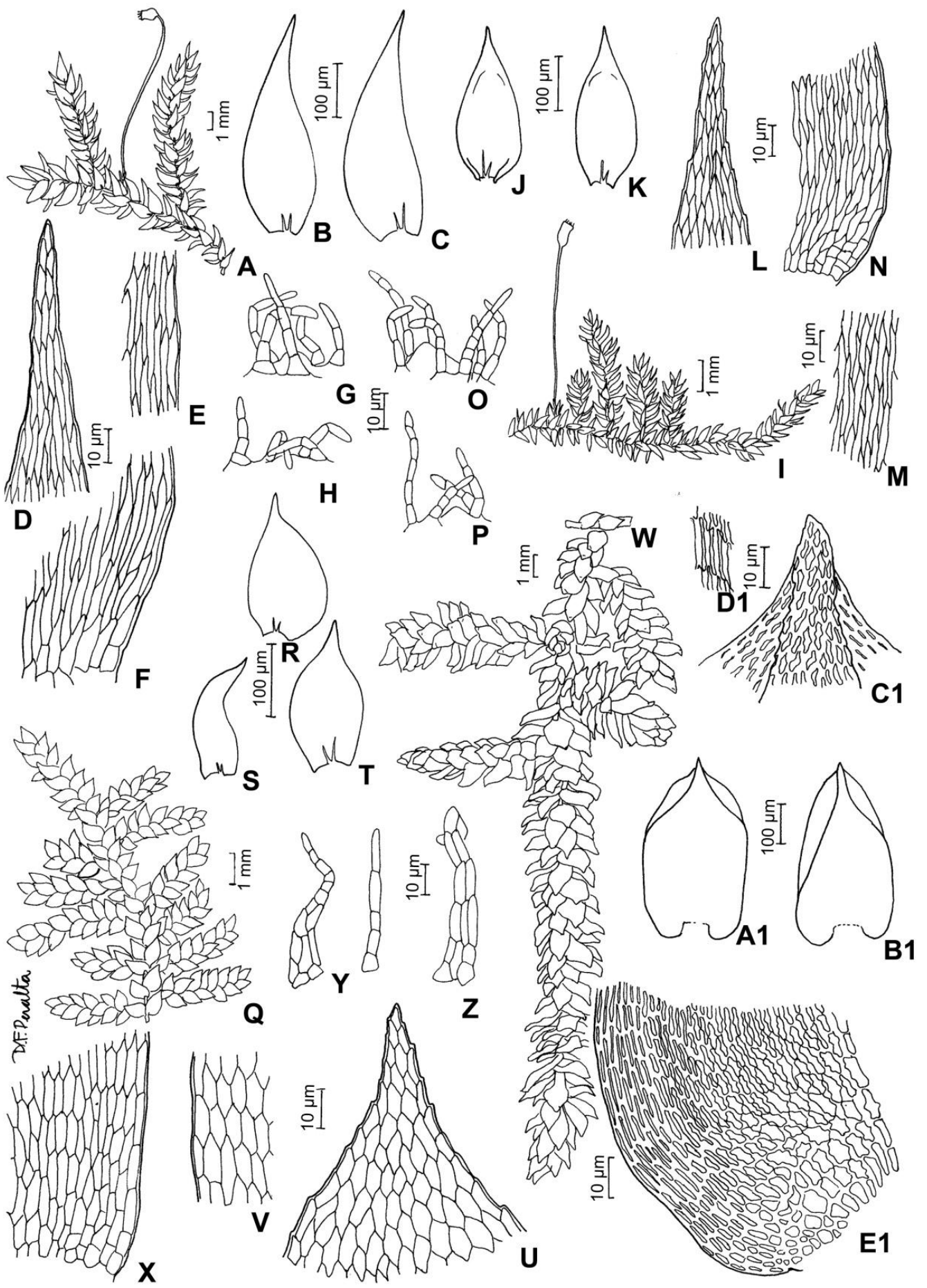

Fig. 18. Isopterygium tenerifolium Mitt. A. aspecto do gametófito. B-C. filídios. D. células do ápice do filídio. E. células da lâmina do filídio. F. células da base do filídio. G-H. pseudoparáfilos. Isopterygium tenerum (Sw.) Mitt. I. aspecto do gametófito. J-K. filídios. I. células do ápice do filídio. M. células da lâmina do filídio. N. células da base do filídio. O-P. pseudoparáfilos. Vesicularia vesicularis (Schwägr.) Broth. Q. aspecto do gametófito. R-T. filídios. U. células do ápice do filídio. V. células da lâmina do filídio. X. células da base do filídio. Y-Z. pseudoparáfilos. Pilotrichella flexilis (Hedw.) Ångstr. W. aspecto do gametófito. A1-B1. filídios. c1. células do ápice do filídio. D1. células da lâmina do filídio. E1. células da base do filídio (A-H. $O$. Yano 530; I-P. Vital 7620; Q-Z. Vital 7587 p.p.; W-E1. Oliveira Filho 5). 
Flora da Serra do Cipó, Minas Gerais: Briófitas (Anthocerotophyta, Bryophyta e Marchantiophyta)

3.2. Isopterygium tenerum (Sw.) Mitt., J. Linn. Soc. Bot. 12: 499. 1869.

Fig. $18 \mathrm{l}-\mathrm{P}$

Gametófitos pequenos, delicados, formando tapetes. Caulídios primários prostrados, secundários ascendentes, pseudoparáfilos filiformes, lisas. Filídios lanceolados, marcadamente assimétricos, côncavos, aplainados, planos quando secos. Costa dupla, curta, ca. 3/10 a 5/10 do compr., estreita, ápice do filídio acuminado, margem do filídio denticulada, células da lâmina longo-hexagonais a lineares, lisas, parede celular delgada, reta, células da base do filídio quadráticas. Seta longa, reta. Cápsula exserta, pêndula ou inclinada, assimétrica, urna ovóide ou subcilíndrica, rômbica, superfície lisa quando seca, ânulo presente. Opérculo rostrado, peristômio duplo. Caliptra glabra.

Material examinado: Minas Gerais, Itambé do Mato Dentro, Vital 7620 (SP136575); Santana do Riacho, Serra da Bandeirinha, O. Yano \& Wanderley 10884 (SP220577); Câmara 1876 (SP419634); Câmara 2005 (SP419688); Dias Neto 89, 90, 92, 93, 131 (SP419731; SP419732; SP419734; SP419735; SP419763).

Ocorre nos estados de AC, AL, AM, AP, BA, CE, ES, DF, GO, MA, MG, MS, MT, PA, PB, PE, PI, PR, RJ, RO, RR, RS, SC, SP e TO. Na Serra do Cipó, cresce em tronco caído e vivo. Os filídios desta espécie apresentam 0 aspecto côncavo e são menores que as demais espécies do gênero que ocorrem no Brasil.

\section{Vesicularia (Müll. Hal.) Müll. Hal.}

Gametófitos medianos, formando tapetes. Caulídios primários prostrados, poucos rizóides, ramos secundários prostrados, pseudoparáfilos folhosos, lisos. Filídios lanceolado ou ovados. Filídios de dois formatos laterais e ventral, marcadamente assimétricos, côncavos ou secundos, aplainados, quando secos crispados ou planos. Costa dupla, curta, ca. 1/10 a 1/20 do compr., estreita, ápice do filídio acuminado ou agudo, margem do filídio plana, denticulada, não bordeada, células da lâmina fusiformes, lisas, parede celular delgada, reta, células da base do filídio quadrático-irregulares. Seta longa, reta. Cápsula exserta, pêndula ou inclinada, assimétrica, urna ovóide ou sub-cilíndrica, rômbica, superfície lisa quando seca, ânulo presente. Opérculo rostrado, peristômio duplo. Caliptra glabra.

4.1. Vesicularia vesicularis (Schwägr.) Broth. in Engler \& Prantl, Natürl. Pflanzenfam. 1(3): 1094. 1908.

Fig. $18 \mathrm{Q}-\mathrm{Z}$

Gametófitos medianos, formando tapetes. Caulídios primários prostrados, secundários prostrados, pseudoparáfilos folhosos, lisos. Filídios ovados. Filídios de dois formatos laterais e ventral, marcadamente assimétricos, côncavos, aplainados quando secos. Costa dupla, curta, ca. 1/10 a 1/20 do compr., estreita, ápice do filídio agudo, margem do filídio plana, denticulada, células da lâmina fusiformes, lisas, células da base do filídio quadrático-irregulares. Seta longa, reta. Cápsula exserta, pêndula ou inclinada, assimétrica, urna ovóide ou sub-cilíndrica, rômbica, superfície lisa quando seca, ânulo presente. Opérculo rostrado, peristômio duplo. Caliptra glabra.

Material examinado: Minas Gerais, Conceição do Mato Dentro, Vital 7587 p.p. (SP132814).

Associada a Marchantia chenopoda L. e Noteroclada confluens Taylor ex Hook. \& Wilson. Ocorre nos estados de AC, AM, ES, GO, MG, MS, MT, PA, PE, PI, RJ, RO, RR, RS, SC e SP. Na Serra do Cipó, cresce em rocha. $O$ aspecto aplainado dos filídios desta espécie e as células grandes e fusiformes são característicos desta espécie.

\section{Lembophyllaceae}

É uma família amplamente distribuída no Brasil, principalmente na Floreta Atlântica, caracterizada principalmente pela ausência de costa larga e o hábito pendente. Ocorre principalmente como corticícola e rupícola. Para a identificação das espécies é necessário analisar o formato dos filídios e as células da região alar. No Brasil ocorrem dois gêneros e sete espécies; na Serra do Cipó ocorre o gênero Pilotrichella com uma espécie.

Bibliografia básica - Gradstein et al. (2001); Sharp et al. (1994); Yano \& Peralta (2009).

\section{Pilotrichella (Müll. Hal.) Besch.}

Gametófitos pleurocárpicos, robustos, formando tapetes. Caulídios primários prostrados, poucos rizóides, ramos secundários dendróides ou pendentes. Filídios lanceolados, côncavos, espiralados ou em fileiras distintas (3-5 fileiras), quando secos imbricados, base do filídio simples ou auriculada. Costa ausente, ápice do filídio apiculado ou pilífero, margem do filídio plana, inteira, não bordeada, células da lâmina lineares, lisas, parede celular delgada, reta, células da base 1-10 fileira de células, muito infladas, marrons a laranja. Seta curta. Cápsula ereta, simétrica, urna ovóide, rômbica, superfície lisa quando seca, ânulo presente. Opérculo rostrado, peristômio duplo. Caliptra glabra.

1.1. Pilotrichella flexilis (Hedw.) Ångstr., Öfvers. K. Svenska Vetensk.-Akad. Handl. 33(11): 34. 1876.

Fig. 18 W-E1

Gametófitos robustos, formando tapetes. Caulídios primários prostrados, ramos secundários dendróides ou pendentes. Filídios lanceolados, côncavos, em fileiras distintas (3-5 fileiras), quando secos imbricados, base do filídio auriculada. Costa ausente, ápice do filídio apiculado, margens do inteira, não bordeada, células da lâmina lineares, lisas, 
células da base 1-10 fileira de células, muito infladas, marrons a laranja. Seta curta. Cápsula ereta, simétrica, urna ovóide, rômbica, superfície lisa quando seca, ânulo presente. Opérculo rostrado, peristômio duplo. Caliptra glabra.

Material examinado: Minas Gerais, Conceição do Mato Dentro, Oliveira Filho 5 (SP90868).

Ocorre nos estados de BA, ES, GO, MG, PE, PR, RJ, RS, SC e SP. Na Serra do Cipó, cresce em tronco de arbusto. Esta espécie apresenta o hábito robusto e uma coloração amarelo-dourada quando os gametófitos estão secos. Comumente apresenta os ramos pendentes muito conspícuos na margem de florestas.

\section{Leucobryaceae}

Gametófitos acrocárpicos, medianos ou robustos, formando tufos. Caulídios primários eretos, ramos secundários ausentes ou raros. Filídios lanceolados, secundos ou canaliculados, espiralados. Costa única, percurrente, ocupando toda a largura do filídio, secção transversal leucocistos em clorocistos em camadas alternadas (leucobrióide), ápice acuminado, margens filídio revolutas ou recurvadas, inteira, não bordeada. Células da lâmina longohexagonais, lisas, parede celular delgada, reta, células da base do filídio (região alar) iguais as da lâmina. Dióicos, monóicos ou autóicos. Seta curta ou longa, reta, marrom-dourada, lisa. Cápsula exserta, ereta, ou inclinada, assimétrica, urna ovóide ou subcilíndrica, rômbica. Peristômio ausente ou único. Caliptra glabra, não plicada.

É uma família amplamente distribuída no Brasil, caracterizada principalmente pela coloração esbranquiçada e costa larga ocupando toda a largura do filídio. Ocorre principalmente como corticícola, terrestre e rupícola. Para a identificação das espécies são necessários cortes transversais do filídio na região da costa, o arranjo dos leucocistos e clorocistos são utilizados para separação de gêneros e espécies. No Brasil ocorrem dois gêneros e 15 espécies; na Serra do Cipó ocorrem três gêneros e 12 espécies.

Bibliografia básica - Gradstein et al. (2001); Sharp et al. (1994); Yano (1992); Yano \& Peralta (2009).

\section{Chave para os gêneros}

1. Filídio muito espesso, rígido, geralmente de costa heterostrósica, 2 aletas basais; clorocistos freqüentemente triangulares ou ovóides em secção transversal do filídio; 8 dentes peristomiais ...... 3. Octoblepharum

1'. Filídio não espesso; costa homostrósica e em parte heterostrósica com lâmina estendendo-se da base até ápice; clorocistos quadrangulares em secção transversal do filídio; 16 dentes peristomiais ou dentes ausentes (gimnóstomo).

2. Caliptra cuculada, base inteira; cápsula cilíndrico-ovalada, inclinada, estrumosa; 2-3 camadas de leucocistos no ápice e 3-8 na base do filídio em secção transversal; 16 dentes peristomiais . ........ 2. Ochrobryum

2'. Caliptra mitrada, franjada ou ciliada na base; cápsula hemisférica, ereta, não estrumosa; $2(1$ e 1) camadas de leucocistos desde o ápice até a base do filídio em secção transversal; peristômio simples

1. Leucobryum

\section{Leucobryum Hampe}

Gametófitos acrocárpicos, medianos ou robustos, formando tufos. Caulídios primários eretos, poucos rizóides, ramos secundários ausentes ou raros. Filídios lanceolados, secundos ou canaliculados, espiralados, quando secos imbricados. Costa única, percurrente, ocupando toda a largura do filídio, secção transversal leucocistos e clorocistos em camadas alternadas (leucobrióide), ápice do filídio acuminado, margem do filídio revoluta ou recurvada, margem inteira, não bordeada, células da lâmina longo-hexagonais, lisas, parede celular delgada, reta, células da base do filídio iguais as da lâmina. Reprodução vegetativa por gemas, no ápice dos filídios. Seta curta ou longa, reta. Cápsula exserta, ereta ou inclinada, assimétrica, urna ovóide ou subcilíndrica, rômbica, superfície lisa quando seca, ânulo presente. Opérculo rostrado. Peristômio simples. Caliptra glabra.

Chave para as espécies

1. Gametófitos $85-200 \mathrm{~mm}$ alt.; filídios $14-22 \mathrm{~mm}$ compr., longos, largos, crispados

1'. Gametófitos 5-80 mm alt.; filídios 3-4 mm compr., estreitos, eretos, lanceolados, às vezes crispados.

2. Filídios crispado-falcados, ca. 14 mm compr.; quando fértil, ânulo presente 
2'. Filídios bem crispados, eretos, lanceolados, geralmente menores que $12 \mathrm{~mm}$ compr., normalmente até $10 \mathrm{~mm}$; ânulo ausente.

3. Costa em secção transversal com 2 (1 e 1) camada de leucocistos desde a base até o ápice.

4. Clorocistos em secção transversal perto da base mais próximo da superfície ventral do filídio; células dos leucocistos convexas em toda superfície

4'. Clorocistos em secção transversal perto da base mais próximo da superfície dorsal do filídio; células dos leucocistos côncavas em toda a superfície

'. Costa em secção transversal com 4-7(8) (2 e 2 ou 3(4)) camadas na base ou 2 camadas na região mediana, irregularmente $4(2$ e 2$)$ próximo à margem.

5. Costa em secção transversal em forma de clava (as duas metades); leucocistos aproximadamente iguais nos lados dorsal e ventral ....

5'. Costa em secção transversal não claviforme; com 4 (2 e 2) camadas de leucocistos irregulares na base marginal ....

1.1. Leucobryum albicans (Schwägr.) Lindb., Öfvers K. Vetensk.-Akad. Förh. 20: 402. 1863.

Fig. 19 A-G

Filídios falcado-crispados, base côncava atingindo $1 / 4$ compr. do filídio, secção transversal da base com 1-2 (1-2 e 1) camadas de leucocistos.

Material examinado: Minas Gerais, Santana do Riacho, Mello Silva et al. 9748 (SP222544, SPF42410); Pirani et al. 10289 (SP230534, SPF170910); Câmara 1953, 1965 (SP419666; SP419676).

Ocorre nos estados de BA, CE, DF, MG, MT, PA, PE, PR, RJ, RS, SC e SP. Na Serra do Cipó, cresce em solo e rocha. Esta espécie apresenta 0 hábito robusto, porém menor que $L$. giganteum e está constantemente associada a solo arenoso próximo de cachoeiras.

1.2. Leucobryum clavatum Hampe, Vidensk. Meddel. Dansk Natuhist. For. ser. 3, 9, 10: 252. 1877.

Fig. $19 \mathrm{H}-\mathrm{L}$

Filídios patentes a imbricados, base côncava atingindo $3 / 4$ compr. do filídio, secção transversal da base com 3-4 (1-2 e 2) camadas de leucocistos.

Material examinado: Minas Gerais, Congonhas do Norte, Serra da Carapina Pirani et al. 4149 (SP284251, SPF170914); Santana do Riacho, Câmara 1931 (SP419653).

Ocorre nos estados de DF, MG, MT, PR, RJ, RS, SC e SP. Na Serra do Cipó, cresce em solo. O aspecto contorcido desta espécie é característico desta espécie.

1.3. Leucobryum crispum Müll. Hal., Syn. Musc. Frond. 1: 78. 1848.

Fig. $19 \mathrm{M}-\mathrm{Q}$

Filídios crispados a contorcidos, base côncava atingindo $1 / 4$ compr. do filídio, secção transversal da base com 2 ( 1 e 1) camadas de leucocistos.
Material examinado: Minas Gerais, Conceição do Mato Dentro, O. Yano 509 (SP135471); O. Yano 537 (SP135491); Vital 7579 (SP136550); Congonhas do Norte, Pirani et al. 5636, 5772 (SP389354, SPF; SP432344, SPF); Itambé do Mato Dentro, Vital 7630 (SP136580); Santana do Riacho, O. Yano \& Wanderley 10663, 10670, 10683, 10827, 10832, 10869 (SP220358; SP220365; SP220378; SP220520; SP220525; SP220562); Pirani et al. 12301 (SPF170917); Câmara 1891, 1904, 2056, 2106, 2108 (SP419639; SP419645; SP419699; SP419712; SP419713); Dias Neto 109, 112, 138, 164 (SP419746; SP419749; SP419768; SP419785).

Ocorre nos estados de AM, AP, BA, CE, DF, ES, GO, MG, MT, PR, RJ, RO, RR, RS, SC e SP. Na Serra do Cipó, cresce em solo arenoso e rocha.

1.4. Leucobryum giganteum Müll. Hal., Syn. Musc. Frond. 1: 79. 1848.

Fig. 19 R-X

Filídios crispados, base côncava atingindo $1 / 4$ compr. do filídio. Filídios ca. 50 a $200 \mathrm{~mm}$ compr., secção transversal da base com 3-2 (1-2 e 1) camadas de leucocistos.

Material examinado: Minas Gerais, Serra do Cipó, Farney 489 (SP222618).

Ocorre nos estados de AL, AM, BA, ES, MG, PE, PR, RJ, RS, SC e SP. Na Serra do Cipó, cresce em solo úmido. Esta é a espécie que apresenta o maior hábito deste gênero. Forma normalmente grandes tufos próximo da base de troncos vivos e rocha.

1.5. Leucobryum laevifolium Broth., Trans. Linn. Soc. Bot. London. ser. 2, 6: 90. 1901.

Fig. 20 A-G

Filídios patentes a imbricados ou falcados, base côncava atingindo 3/4 compr. do filídio, secção transversal da base com 2 (1 e 1) camadas de leucocistos.

Material examinado: Minas Gerais, Santana do Riacho, O. Yano \& Wanderley 10648 (SP220343). 


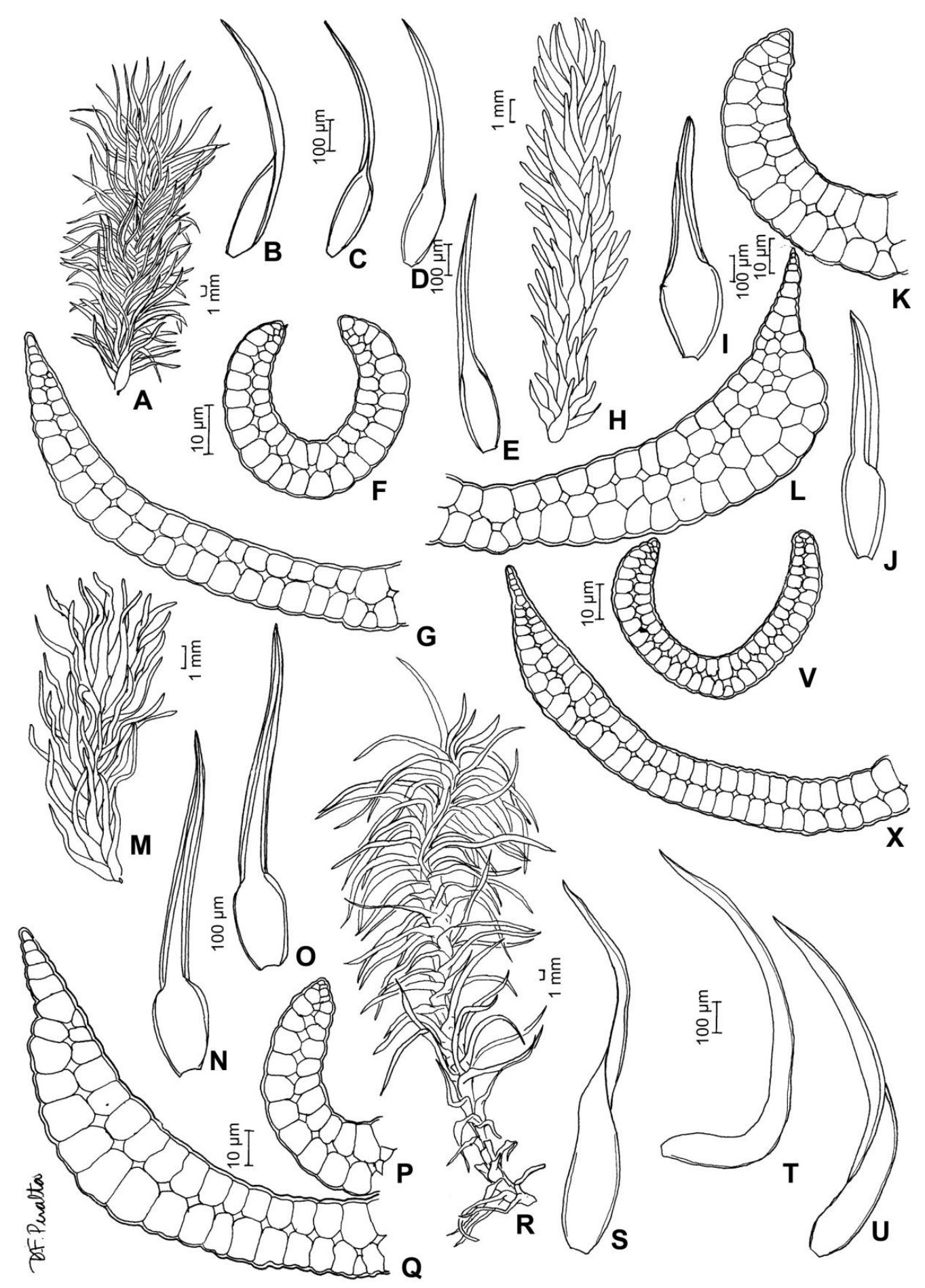

Fig. 19. Leucobryum albicans (Schwägr.) Lindb. A. aspecto do gametófito. B-E. filídios. F. secção transversal do filídio na região mediana. G. secção transversal do filídio na região basal. Leucobryum clavatum Hampe. H. aspecto do gametófito. I-J. filídios. k. secção transversal do filídio na região mediana. L. secção transversal do filídio na região basal. Leucobryum crispum Müll. Hal. M. aspecto do gametófito. N-O. filídios. P. secção transversal do filídio na região mediana. Q. secção transversal do filídio na região basal. Leucobryum giganteum Müll. Hal. R. aspecto do gametófito. S-U. filídios. V. secção transversal do filídio na região mediana. X. secção transversal do filídio na região basal (A-G. Mello Silva et al. 9748; H-L. Pirani et al. 4149; M-Q. O. Yano 509; R-X. Farney 489). 
Flora da Serra do Cipó, Minas Gerais: Briófitas (Anthocerotophyta, Bryophyta e Marchantiophyta)

Ocorre nos estados de AM, MG, MT, RJ, RS, SC e SP. Na Serra do Cipó, cresce em rocha.

1.6. Leucobryum martianum (Hornsch.) Hampe, Linnaea 17: 317. 1843.

Fig. $20 \mathrm{H}-\mathrm{L}$

Gametófitos 10-35mm alt., verdeesbranquiçados. Filídios falcados unilateralmente. Costa em secção transversal; ápice região mediana e base 2(1 e 1) camadas de leucocistos com paredes irregulares e concavidades no lado dorsal. Lâminas alongadas com 5-6(-9) fileiras de células leucocísticas.

Material examinado: Minas Gerais, Conceição do Mato Dentro, Vital 1241 (SP88514); O. Yano 507 (SP135469); O. Yano 526 (SP135482); Santana do Riacho, Pirani et al. 5544, 10330 (SP230535, SPF; SP388482, SPF); O. Yano \& Wanderley 10659 (SP220354); Câmara et al. 2113, 2131, 2149 (SP419715; SP419717; SP419719); Dias Neto 121 (SP419756).

Ocorre nos estados de AC, AL, AM, AP, BA, CE, DF, ES, MA, MG, MS, MT, PA, PE, PR, RJ, RO, RR, RS, SC, SE, SP e TO. Na Serra do Cipó, cresce em solo e rocha. Esta espécie comumente apresenta todos os filídios falcados lateralmente, apresentando desta maneira um aspecto fácil de identificar.

\section{Ochrobryum Mitt.}

Gametófitos acrocárpicos, medianos ou robustos, formando tufos. Caulídios primários eretos, poucos rizóides, ramos secundários ausentes ou raros. Filídios lanceolados, canaliculados, espiralados, quando secos imbricados. Costa única, percurrente, ocupando toda a largura do filídio, secção transversal leucocistos e clorocistos em camadas alternadas (leucobrióide), ápice do filídio acuminado. Margem do filídio revoluta ou recurvada, margem inteira, não bordeada, células da lâmina longo-hexagonais. Reprodução vegetativa por gemas, ápice dos filídios. Seta curta ou longa, reta. Cápsula exserta, ereta ou inclinada, assimétrica, urna ovóide ou sub-cilíndrica, rômbica, superfície lisa quando seca, ânulo presente. Opérculo rostrado. Peristômio simples. Caliptra glabra.
2.1. Ochrobryum gardneri (Müll. Hal.) Mitt., J. Linn. Soc. Bot. 12: 108. 1869.

Fig. $20 \mathrm{M}-\mathrm{Q}$

Gametófitos 4-7mm alt., verde-esbranquiçados ou verde-amarelados. Filídios eretos, ápice agudo com muitos propágulos globosos. Costa em secção transversal com ápice, região mediana e base 2(1 e 1) camadas de leucocistos. Lâminas com 5-6 fileiras de células leucocísticas diminuindo até 2 fileiras na região mediana e ápice.

Material examinado: Minas Gerais, Santana do Riacho, O. Yano \& Wanderley 10621, 10672, 10684 (SP220316; SP220367; SP220379); Serra da Bandeirinha, $O$. Yano \& Wanderley 10715, 10716, 10784, 10834, 10888 (SP220410; SP220411; SP220477; SP220527; SP220581); Pirani et al. 6272 (SP432413, SPF); Prado s/n (SP220628); Câmara 1847, 1851 (SP41923; SP41924); Dias Neto 78, 79 , 80, 105, 107 (SP419727; SP419728; SP419729; SP419742; SP419744).

Ocorre nos estados de AL, AM, BA, CE, DF, ES, GO, MG, MS, MT, PA, PE, PR, RJ, RO, RR, SP e TO. Na Serra do Cipó, cresce em tronco vivo e caído. No ápice dos filídios ocorrem tufos de propágulos.

\section{Octoblepharum Hedw.}

Gametófitos acrocárpicos, robustos, formando tufos. Caulídios primários eretos, poucos rizóides, ramos secundários ausentes ou raros. Filídios lanceolados, espiralados, quando secos espalhados. Costa única, percurrente, ocupando toda a largura do filídio, secção transversal leucocistos em clorocistos em camadas alternadas (leucobrióide), ápice do filídio obtuso, apiculado, margem do filídio plana, inteira, não bordeada, células da lâmina longo-hexagonais, lisas, parede celular delgada, reta, células da base do filídio iguais as da lâmina. Reprodução vegetativa por gemas, ápice dos filídios. Seta curta ou longa, reta. Cápsula ereta, assimétrica, urna ovóide ou subcilíndrica, rômbica, superfície lisa quando seca, ânulo presente. Opérculo rostrado. Peristômio simples. Caliptra glabra.

Chave para as espécies

1. Filídios acima de $20 \mathrm{~mm}$ compr.; ápice formado por 3-4 células alongadas convergindo para o ápice acuminado

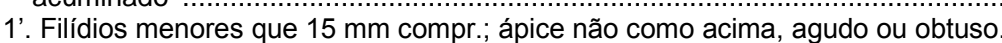

2. Ápice do filídio obtuso, geralmente denteado; células na parte central da lâmina retangulares 3.4. O. erectifolium

2'. Ápice do filídio agudo ou apiculado, geralmente inteiro; células na parte central da lâmina quadrática a retangulares.

3. Costa em secção transversal com constrição da aleta para a costa; ápice agudo, às vezes apiculados

3'. Costa em secção transversal com pouca ou sem constrição da aleta para a costa; ápice agudo ou obtuso. 


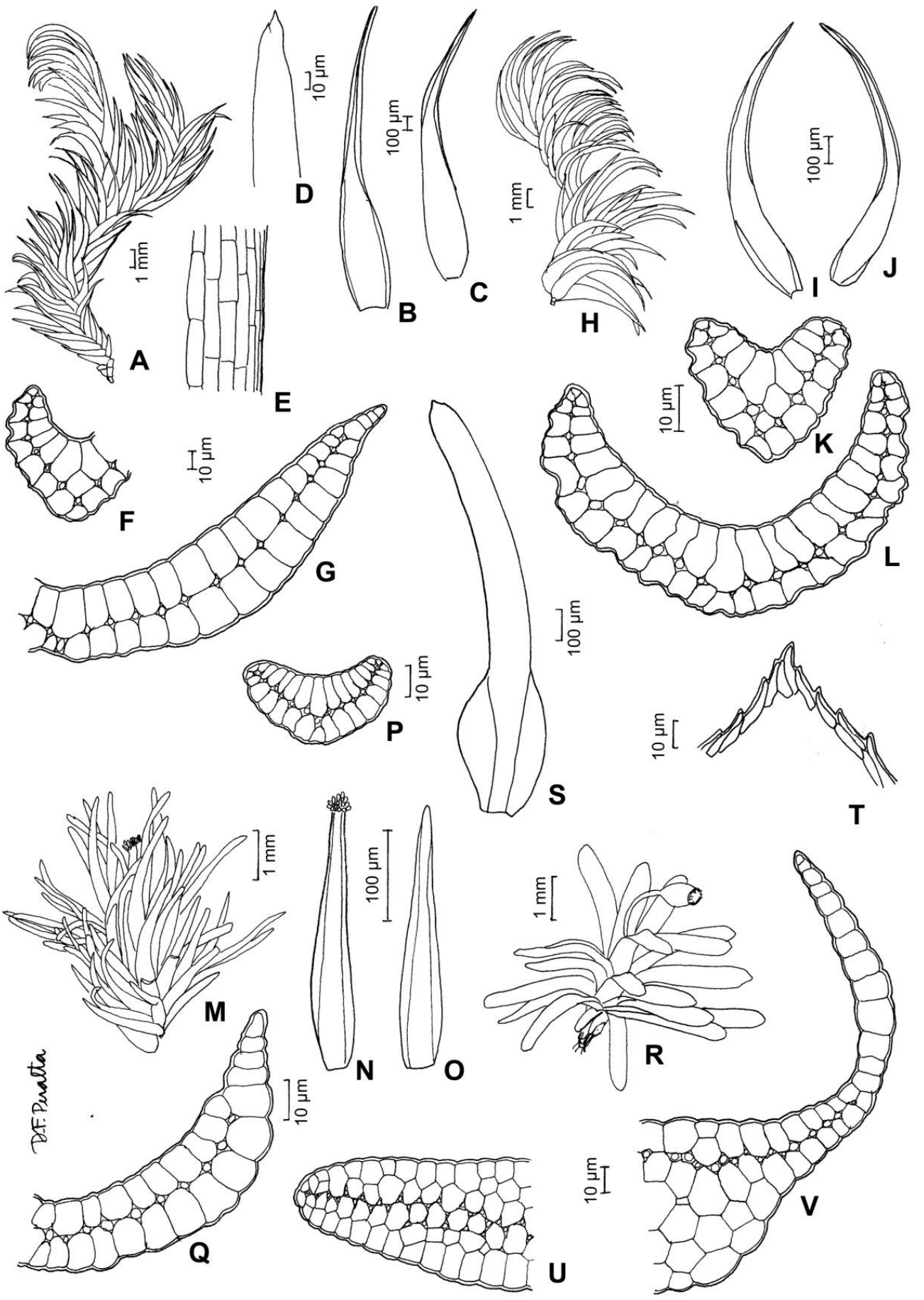

Fig. 20. Leucobryum laevifolium Broth. A. aspecto do gametófito. B-C. filídios. D. ápice do filídio. E. células da margem do filídio. F. secção transversal do filídio na região mediana. G. secção transversal do filídio na região basal. Leucobryum martianum (Hornsch.) Hampe. H. aspecto do gametófito. I-J. filídios. K. secção transversal do filídio na região apical. L. secção transversal do filídio na região basal. Ochrobryum gardneri (Müll. Hal.) Mitt. M. aspecto do gametófito. N-O. filídios. P. secção transversal do filídio na região apical. Q. secção transversal do filídio na região basal. Octoblepharum albidum Hedw. R. aspecto do gametófito. S. filídio. T. ápice do filídio. U. secção transversal do filídio na região mediana. V. secção transversal do filídio na região basal (A-G. O. Yano \& Wanderley 10648; H-L. Vital 1241; M-Q. O. Yano \& Wanderley 10621; R-V. O. Yano 520). 
4. Costa com 8 ( 3 e 5) camadas de leucocistos na base; pouca constrição da aleta para a costa; células irregulares na metade superior da aleta; ápice obtuso e células alongadas convergindo para o ápice

4'. Costa com 4 ( 2 e 2) camadas de leucocistos na base; quase sem constrição da aleta para a costa; células hexagonais a retangulares na metade superior da aleta; ápice agudo; uma das aletas com até 12 células leucocísticas de largura

3.1. Octoblepharum albidum Hedw., Spec. Musc. Frond.: 50. 1801.

Fig. $20 \mathrm{R}-\mathrm{V}$

Filídios menores que $15 \mathrm{~mm}$ compr.; ápice agudo ou obtuso, geralmente denteado. Filídio muito espesso e rígido, geralmente de costa heterostrósica, 2 aletas basais; clorocistos freqüentemente triangulares ou ovóides em secção transversal do filídio; 8 dentes peristomiais; células na parte central da lâmina retangulares.

Material examinado: Minas Gerais, Conceição do Mato Dentro, O. Yano 520 (SP135478); Santana do Riacho, Pirani et al. 6271 p.p., 10381 (SP432412, SPF; SP230732, SPF170922); O. Yano \& Wanderley 10631, 10667, 10700 (SP220326; SP220362; SP220395); idem, Serra da Bandeirinha, O. Yano \& Wanderley 10768, 10771, 10775 (SP220462; SP220465; SP220468); Câmara 1856 (SP419627); Dias Neto 103 (SP419740).

Ocorre em todos os estados e no DF e FN. Na Serra do Cipó, cresce em rocha, tronco caído e vivo. Associada a Pterogonidium pulchellum (Hook.) Müll. Hal. ex Broth. Esta é a espécie mais comum e amplamente distribuída deste gênero, ocorre em vários substratos e varia consideravelmente no tamanho dos gametófitos e filídios.

3.2. Octoblepharum ampullaceum Mitt., J. Linn. Soc. Bot. 12: 109. 1869.

Fig. $21 \mathrm{~A}-\mathrm{E}$

Filídios menores que $15 \mathrm{~mm}$ compr.; ápice agudo ou obtuso, geralmente inteiro. Filídio muito espesso e rígido, geralmente de costa heterostrósica, costa em secção transversal com pouca ou sem constrição da aleta para a costa; 4 (2 e 2) camadas de leucocistos na base; quase sem constrição da aleta para a costa; células hexagonais a retangulares na metade superior da aleta; 2 aletas basais; uma das aletas com até 12 células leucocisticas de largura; clorocistos freqüentemente triangulares ou ovóides em secção transversal do filídio; ápice agudo ou obtuso, células na parte central da lâmina quadrática a retangulares.

Material examinado: Minas Gerais, Conceição do Mato Dentro, O. Yano 518 (SP135476).

Ocorre nos estados de AM, DF, MG, MT, PA, RO e RR. Na Serra do Cipó, cresce no solo arenoso entre as frestas de pedras.
3.3. Octoblepharum cocuiense Mitt., J. Linn. Soc. Bot. 12: 109. 1869.

Fig. 21 F-J

Filídios menores que $15 \mathrm{~mm}$ compr.; ápice do filídio agudo ou apiculado, geralmente inteiro. Filídio muito espesso e rígido, geralmente de costa heterostrósica, 2 aletas basais, com constrição da aleta para a costa; clorocistos freqüentemente triangulares ou ovóides em secção transversal do filídio; células na parte central da lâmina quadrática a retangulares.

Material examinado: Minas Gerais, Conceição do Mato Dentro, Vital 7576, 7584, 7586 (SP136547; SP136554; SP136556).

Ocorre nos estados de AC, AM, BA, CE, ES, GO, MG, MS, MT, PA, PR, RJ, RO, RR, SE, SP e TO. $\mathrm{Na}$ Serra do Cipó, cresce em rocha. Os filídios desta espécie apresentam o aspecto sedoso-membranáceo, fácil de diferenciar das demais espécies.

3.4. Octoblepharum erectifolium Mitt. ex R.S. Williams, N. Amer. Flora 15(2): 162. 1913.

Fig. $21 \mathrm{~K}-\mathrm{O}$

Filídios acima de $20 \mathrm{~mm}$ compr., muito espesso e rígido, geralmente de costa heterostrósica, costa aguda, ápice formado por 3-4 células alongadas convergindo para o ápice acuminado 2 aletas basais; clorocistos freqüentemente triangulares ou ovóides em secção transversal do filídio; 8 dentes peristomiais.

Material examinado: Minas Gerais, Santana do Riacho, Cachoeira Farofa, O. Yano \& Wanderley 10651 (SP220346); Câmara 1955 (SP419668).

Ocorre nos estados de AM, DF, MG, MT, PA, $\mathrm{RO}$ e SP. Na Serra do Cipó, cresce em rocha e tronco vivo. Os filídios desta espécie podem ficar bastante longos e são caracteristicamente rígidos.

\subsection{Octoblepharum pulvinatum (Dozy \& Molk.)} Mitt., J. Linn. Soc. Bot. 12: 109. 1869.

Fig. 21 P-T

Filídios menores que $15 \mathrm{~mm}$ compr.; ápice agudo ou apiculado. Filídio muito espesso e rígido, geralmente de costa heterostrósica, secção transversal 8 ( 3 e 5) camadas de leucocistos na base, 2 aletas basais, com pouca ou sem constrição da aleta 


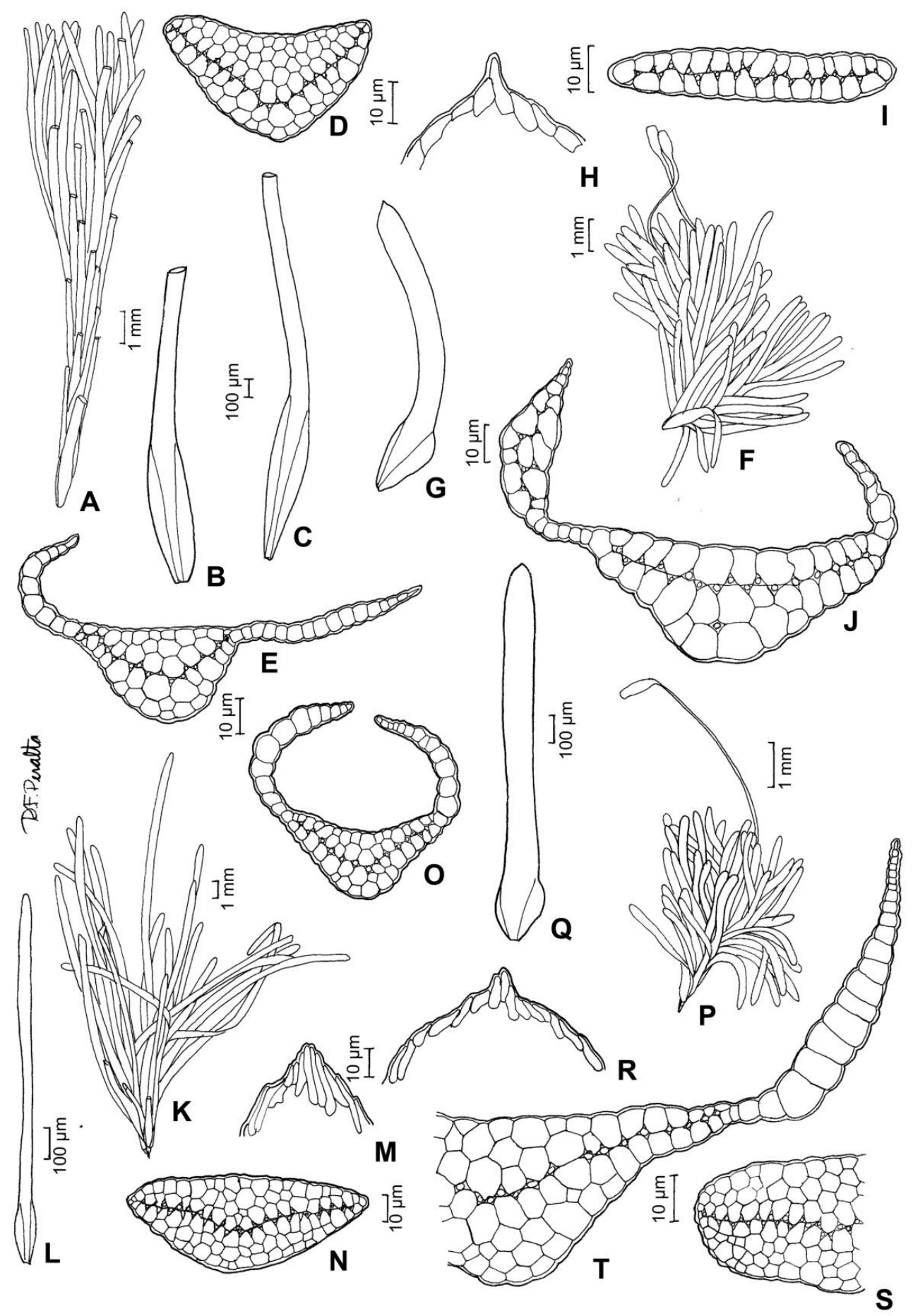

Fig. 21. Octoblepharum ampullaceum Mitt. A. aspecto do gametófito. B-C. filídios. D. secção transversal do filídio na região mediana. E. secção transversal do filídio na região basal. Octoblepharum cocuiense Mitt. F. aspecto do gametófito. G. filídio. $H$. ápice do filídio. I. secção transversal do filídio na região mediana. J. secção transversal do filídio na região basal. Octoblepharum erectifolium Mitt. ex R.S. Williams. K. aspecto do gametófito. L. filídio. M. ápice do filídio. N. secção transversal do filídio na região mediana. O. secção transversal do filídio na região basal. Octoblepharum pulvinatum (Dozy \& Molk.) Mitt. P. aspecto do gametófito. Q. filídio. R. ápice do filídio. S. secção transversal do filídio na região mediana. T. secção transversal do filídio na região basal (A-E. O. Yano 518; F-J. Vital 7576; K-O. O. Yano \& Wanderley 10651; P-T. O. Yano \& Wanderley 10641). 
Flora da Serra do Cipó, Minas Gerais: Briófitas (Anthocerotophyta, Bryophyta e Marchantiophyta)

para a costa; clorocistos freqüentemente triangulares ou ovóides em secção transversal do filídio, células na parte central da lâmina quadrática a retangulares.

Material examinado: Minas Gerais, Santana do Riacho, Cachoeira Farofa, O. Yano \& Wanderley 10641 (SP220336).

Ocorre nos estados de AC, AL, AM, AP, BA, CE, ES, GO, MA, MG, MS, MT, PA, PE, RJ, RO, RR, SC, SP e TO. Na Serra do Cipó, cresce em rocha.

\section{Leucomiaceae}

É uma família amplamente distribuída no Brasil, caracterizada principalmente pela ausência de costa e as células da lâmina do filídio longo-hexagonais a fusiformes. Ocorre comumente como terrícola e corticícola e está sempre associada a locais úmidos e protegidos. Para a identificação das espécies é necessário análise do formato dos filídios. No Brasil ocorrem três gêneros e cinco espécies; na Serra do Cipó ocorre o gênero Leucomium com uma espécie.

Bibliografia básica - Gradstein et al. (2001); Sharp et al. (1994); Yano \& Peralta (2009).

\section{Leucomium Mitt.}

\begin{abstract}
Gametófitos pleurocárpicos, medianos, formando tapetes. Caulídios primários prostrados, poucos rizóides, ramos secundários prostrados. Filídios lanceolados, planos, espiralados, planos quando secos. Costa ausente, ápice do filídio pilífero ou acuminado, margem do filídio plana, inteira, não bordeada, células da lâmina fusiformes ou longohexagonais, lisas, parede celular delgada, reta, células da base do filídio iguais as da lâmina. Seta longa, reta. Cápsula exserta, inclinada ou horizontal, assimétrica, urna ovóide ou sub-cilíndrica, rômbica, superfície lisa quando seca, ânulo presente. Opérculo rostrado, peristômio duplo. Caliptra glabra.
\end{abstract}

1.1. Leucomium strumosum (Hornsch.) Mitt., J. Linn. Soc. Bot. 12: 502. 1869.

Fig. 22 A-G

Gametófitos medianos, formando tapetes. Caulídios primários prostrados. Filídios lanceolados. Costa ausente, ápice do filídio acuminado, margens inteira, células da lâmina longo-hexagonais, lisas, parede celular delgada, reta, células da base do filídio iguais as da lâmina. Seta longa, reta. Cápsula exserta, inclinada ou horizontal, assimétrica, urna ovóide ou sub-cilíndrica, rômbica, superfície lisa quando seca, ânulo presente. Opérculo rostrado, peristômio duplo. Caliptra glabra.

Material examinado: Minas Gerais, Santana do Riacho, Serra da Bandeirinha, O. Yano \& Wanderley 10850 (SP220543).
Ocorre nos estados de AC, AL, AM, AP, BA, ES, MG, PA, PE, RJ, RO, RR, SC e SP. Na Serra do Cipó, cresce em solo arenoso. Esta espécie pode ser confundida com as espécies de Vesicularia porém Leucomium não apresenta costa curta e dupla, nem pseudoparáfilos que são característicos em Vesicularia.

\section{Meteoriaceae}

É uma família amplamente distribuída no Brasil, primariamente associada a áreas de Floresta Atlântica e matas-de-galeria, caracterizada principalmente pela costa simples e as células da lâmina papilosas. Ocorre principalmente como corticícola e rupícola e está sempre associada a locais ventilados e expostos diretamente. Para a identificação das espécies é necessário analisar o formato dos filídios e das células da lâmina. No Brasil ocorrem dez gêneros e 44 espécies; na Serra do Cipó ocorre o gênero Floribundaria com uma espécie.

Bibliografia básica - Gradstein et al. (2001); Sharp et al. (1994); Yano \& Peralta (2009).

\section{Floribundaria M. Fleisch.}

Gametófitos pleurocárpicos, medianos, formando tapetes. Caulídios primários prostrados, poucos rizóides, ramos secundários pendentes. Filídios lanceolados, planos ondulados longitudinalmente (plicados), espiralados, quando secos imbricados, base do filídio auriculada. Costa única, atingindo até $1 / 2$ ou 3/4 compr. do filídio ou percurrente, estreita, ápice do filídio pilífero ou acuminado, margem do filídio plana, denticulada, não bordeada, células da lâmina fusiformes ou longohexagonais, pouco alongadas, papilosas, sobre a parede e lúmen das células, parede celular delgada, reta, células da base do filídio quadrático-irregulares. Seta curta, reta. Cápsula exserta, ereta ou inclinada, simétrica, urna ovóide ou sub-cilíndrica, rômbica, superfície lisa quando seca, ânulo presente. Opérculo rostrado, peristômio duplo. Caliptra glabra.

1.1. Floribundaria flaccida (Mitt.) Broth. in Engler \& Prantl, Natürl. Pflanzenfam. 1(3): 822. 1906.

Fig. $22 \mathrm{H}-\mathrm{G}$

Gametófitos medianos. Caulídios primários prostrados, ramos secundários pendentes. Filídios lanceolados, espiralados, base do filídio auriculada. Costa única, atingindo até 1/2 ou 3/4 compr. do filídio, estreita, ápice do filídio acuminado, denticulada, células da lâmina longo-hexagonais, pouco alongadas, papilosas, parede celular delgada, reta, células da base do filídio quadrático-irregulares. Seta curta, reta. Cápsula exserta, ereta ou inclinada, simétrica, urna ovóide ou sub-cilíndrica, rômbica, superfície lisa quando seca, ânulo presente. Opérculo rostrado, peristômio duplo. Caliptra glabra. 


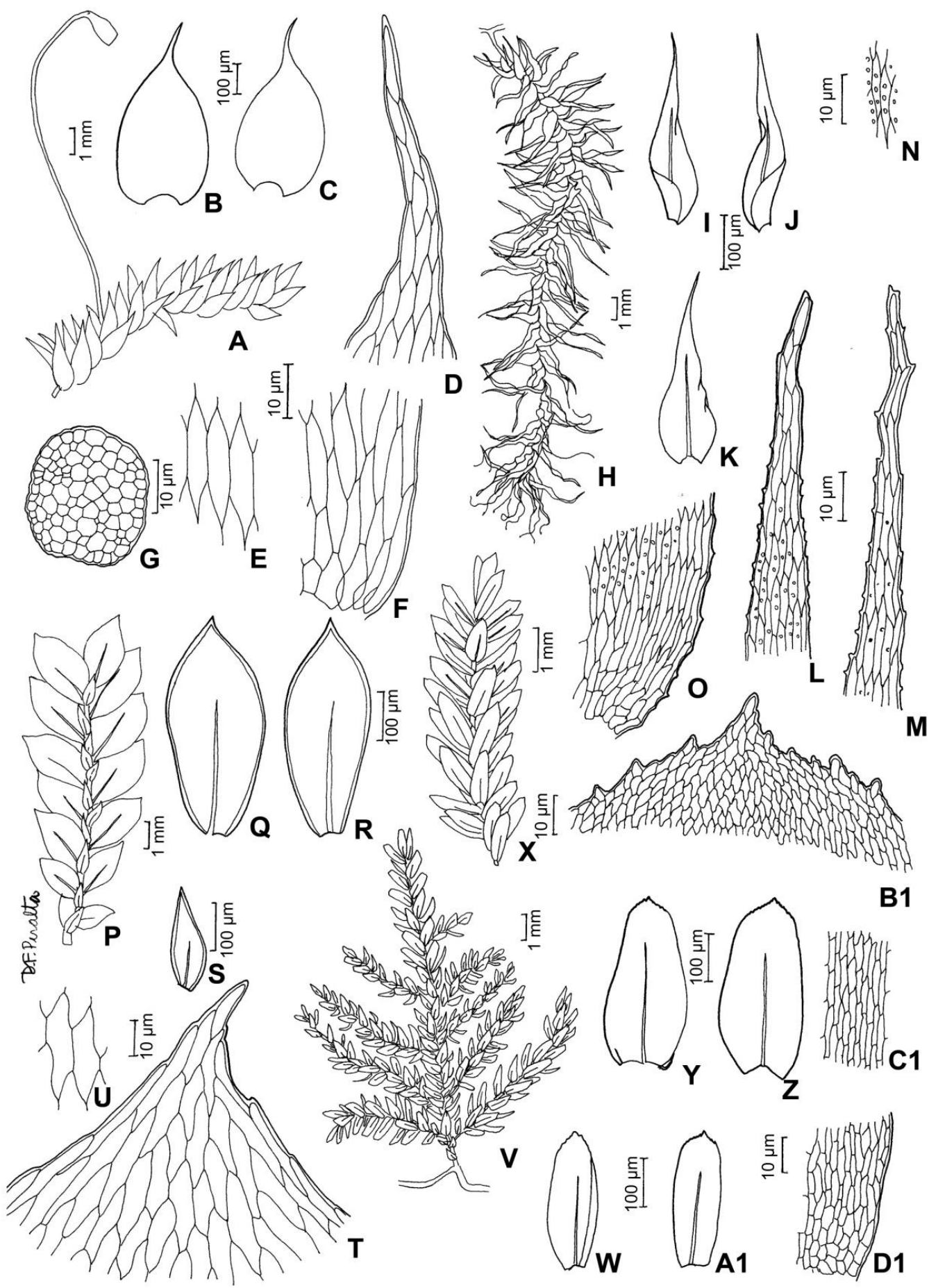

Fig. 22. Leucomium strumosum (Hornsch.) Mitt. A. aspecto do gametófito. B-C. filídios. D. células do ápice do filídio. E. células da lâmina do filídio. F. células da base do filídio. G. secção transversal do caulídio. Floribundaria flaccida (Mitt.) Broth. H. aspecto do gametófito. I-K. filídios. L-M. células do ápices dos filídios. N. células da lâmina do filídio. O. células da base do filídio. G. secção transversal do caulídio. Epipterygium puiggarii (Geh. \& Hampe) Broth. P. aspecto do gametófito. Q-R. filídios laterais. S. filídio dorsal. T. células do ápice do filídio. U. células da lâmina do filídio. Porotrichum longirostre (Hook.) Mitt. V. aspecto do gametófito. X. detalhe de um ramo. Y-Z. filídios do caulídio. W-A1. filídios dos ramos. B1. células do ápice do filídio. C1. células da lâmina do filídio. D1. células da base do filídio (A-G. O. Yano \& Wanderley 10850; H-O. Pirani et al. 5634; P-U. Vital 7588 p.p.; V-D1. O. Yano \& Wanderley 10845 p.p.). 
Flora da Serra do Cipó, Minas Gerais: Briófitas (Anthocerotophyta, Bryophyta e Marchantiophyta)

Material examinado: Minas Gerais, Congonhas do Norte, Serra Talhada, Pirani et al. 5634 (SP389352; SPF).

Ocorre nos estados de BA, CE, ES, GO, MG, MT, PE, PR, RJ, RS, SC e SP. Na Serra do Cipó, cresce em tronco vivo. Os gametófitos desta espécie são longos e pendentes, porém apresentam aspecto delicado e uma coloração verde-claro opaca.

\section{Mniaceae}

É uma família com ocorrência pontual no Brasil, caracterizada principalmente pelo hábito pequeno e aspecto delicado dos gametófitos. Ocorre principalmente como terrestre. Para a identificação das espécies é necessário analisar principalmente as características do esporófito. No Brasil ocorrem seis gêneros e 22 espécies; na Serra do Cipó ocorre o gênero Epipterygium com uma espécie.

Bibliografia básica - Gradstein et al. (2001); Sharp et al. (1994).

\section{Epipterygium Lindb.}

Gametófitos acrocárpicos, pequenos, delicados, formando tufos. Caulídios primários eretos, poucos rizóides, ramos secundários ausentes ou raros. Filídios ligulado. Filídios de dois formatos laterais e ventral, planos, dísticos, planos quando secos. Costa única, atingindo até $1 / 2$ ou $3 / 4$ compr. do filídio, estreita, ápice do filídio apiculado ou agudo, margem do filídio plana, inteira, bordeada, células da lâmina longo-hexagonais, lisas, reta, células da base do filídio iguais as da lâmina. Seta longa, reta. Cápsula exserta, inclinada, assimétrica, urna piriforme ou subcilíndrica, rômbica, superfície lisa quando seca, ânulo presente. Opérculo cônico, peristômio duplo. Caliptra glabra.

1.1. Epipterygium puiggarii (Geh. \& Hampe) Broth. in Engler \& Prantl, Natürl. Pflanzenfam. 1(3): 555. 1902.

Fig. 22 P-U

Gametófitos pequenos, delicados. Caulídios primários eretos. Filídios ligulado. Filídios de dois formatos laterais e ventral, planos, dísticos. Costa única, atingindo até $1 / 2$ ou $3 / 4$ compr. do filídio, estreita, ápice do filídio apiculado, margem do filídio inteira, bordeada, células da lâmina longo-hexagonais, lisas, reta, células da base do filídio iguais as da lâmina. Seta longa, reta. Cápsula exserta, inclinada, assimétrica, urna piriforme ou sub-cilíndrica, rômbica, superfície lisa quando seca, ânulo presente. Opérculo cônico, peristômio duplo. Caliptra glabra.

Material examinado: Minas Gerais, Conceição do Mato Dentro, Vital 7588 p.p. (SP132815).
Associada a Dumortiera hirsuta (Sw.) Nees. Ocorre nos estados de RJ e SP. Na Serra do Cipó, cresce em rocha.

\section{Neckeraceae}

É uma família amplamente distribuída no Brasil, caracterizada principalmente pelo hábito dendróide e costa conspícua. Ocorre principalmente como corticícola e está sempre associada a locais protegidos. Para a identificação das espécies é necessário análise do formato dos filídios. No Brasil ocorrem dez gêneros e 47 espécies; na Serra do Cipó ocorre uma espécie de Porotrichum.

Bibliografia básica - Gradstein et al. (2001); Sharp et al. (1994); Yano \& Peralta (2009).

\section{Porotrichum (Brid.) Hampe}

Gametófitos pleurocárpicos, medianos ou robustos, formando tufos. Caulídios primários prostrados, tomentosos, ramos secundários dendróides, pseudoparáfilos lisos. Filídios ligulados, lanceolados ou ovados, marcadamente assimétricos, planos ou ondulados transversalmente, aplainados, planos quando secos. Costa única, 1/2 ou 3/4 compr. do filídio ou percurrente, estreita, ápice do filídio apiculado, obtuso, agudo ou truncado, margem do filídio plana, inteira ou denticulada, não bordeada, células da lâmina fusiformes ou longo-hexagonais ou quadrático-irregulares, pouco alongadas ou isodiamétricas, lisas, parede celular delgada, reta, células da base do filídio iguais as da lâmina ou quadrático-irregulares. Seta curta ou longa, reta. Cápsula pêndula ou ereta, simétrica, urna ovóide ou sub-cilíndrica, rômbica, superfície lisa quando seca. Opérculo rostrado, peristômio duplo. Caliptra glabra.

1.1. Porotrichum longirostre (Hook.) Mitt., J. Linn. Soc. Bot. 12: 461. 1869.

Fig. 22 V-D1

Gametófitos medianos ou robustos, formando tufos. Caulídios primários prostrados, ramos secundários dendróides. Filídios ligulados, planos, aplainados, planos quando secos. Costa única, 1/2 ou 3/4 compr. do filídio ou percurrente, estreita, ápice do filídio obtuso, margem do filídio plana, denticulada, células da lâmina longo-hexagonais, lisas, parede celular delgada, reta, células da base do filídio quadrático-irregulares. Seta longa, reta. Cápsula ereta, simétrica, sub-cilíndrica, rômbica, superfície lisa quando seca. Opérculo rostrado, peristômio duplo. Caliptra glabra.

Material examinado: Minas Gerais, Santana do Riacho, Serra da Bandeirinha, O. Yano \& Wanderley 10845 p.p. (SP220538) 
Associada a Plagiochila rutilans Lindenb. $e$ Lopholejeunea nigricans (Lindenb.) Schiffn. Ocorre nos estados de ES, MG, MS, MT, SC, RJ, RS e SP. $\mathrm{Na}$ Serra do Cipó, cresce em tronco vivo. O formato ligulado dos filídios distais dos ramos são característicos desta espécie e auxiliam na diferenciação da espécie mais comum do gênero $P$. substriatum, que apresenta os filídios oblongolanceolados.

\section{Orthotrichaceae}

Gametófitos cladocárpicos, medianos ou robustos, formando tapetes. Caulídios primários prostrados, tomentosos, ramos secundários ascendentes. Filídios ligulados ou lanceolado, planos, crispados ou ondulados longitudinalmente (plicados), espiralados, quando secos crispados, base simples, ápice apiculado, obtuso ou agudo, margem plana, inteiras, denticuladas ou denteadas, não bordeado. Costa única, percurrente, estreita. Células da lâmina fusiformes, circulares ou quadrático irregulares, isodiamétricas, lisas, mamilosas ou papilosas, parede celular espessada, reta, região alar mais claras e alongadas porém não infladas. Dióicos, monóicos ou autóicos. Seta curta ou longa, reta, marrom-dourada, torcida ou lisa. Cápsula exserta, emergente ou imersa, ereta, simétrica, urna ovóide ou subcilíndrica, rômbica. Peristômio duplo. Caliptra pequena, pilosa ou glabra, plicada ou não.

É uma família amplamente distribuída no Brasil, caracterizada principalmente pelo hábito prostrado dos caulídios primários e ascendente dos secundários e a costa simples. Ocorre principalmente como corticícola e rupícola. Para a identificação das espécies é necessário análise da morfologia das células da lâmina do filídio. No Brasil ocorrem oito gêneros e 119 espécies; na Serra do Cipó ocorrem quatro gêneros e oito espécies.

Bibliografia básica - Gradstein et al. (2001); Sharp et al. (1994); Yano \& Peralta (2009).

Chave para os gêneros

1. Gametófitos marrom-avermelhados; células da base porosas; lâmina do filídio plana ou plicada transversalmente

1'. Gametófitos verde-escuros; células da base não porosas; lâmina do filídio plicada longitudinalmente.

2. Filídios quando secos imbricados, ápice agudo; gametófitos estreitos e delicados; caliptra persistente e cobrindo a cápsula

2'. Filídios quando secos contorcidos, ápice acuminado; gametófitos robustos; caliptra decídua.

3. Caliptra pilosa; margem da base do filídio não bordeada por várias camadas de células lineares; parede celular espessada

3'. Caliptra glabra; margem da base do filídio bordeada por várias camadas de células longas: parede celular delgada

4. Schlotheimia 2. Macrocoma

3. Macromitrium 1. Groutiella

\section{Groutiella Steere}

Gametófitos cladocárpicos, robustos, formando tapetes. Caulídios primários prostrados, tomentosos, ramos secundários ascendentes. Filídios ligulados, planos, espiralados, quando secos crispados. Costa única, percurrente, estreita, ápice do filídio apiculado, margem do filídio plana, inteira, não bordeada, células da lâmina circulares, isodiamétricas, mamilosas, parede celular espessada, reta, células da base do filídio mais claras, alongadas porém não infladas, filídios periqueciais igual aos demais. Seta longa, reta, torcida ou lisa. Cápsula exserta, ereta, simétrica, urna ovóide ou sub-cilíndrica, rômbica, superfície quando seca estriada, ânulo presente. Opérculo rostrado, peristômio duplo. Caliptra pequena, glabra.

1.1. Groutiella tomentosa (Hornsch.) Wijk \& Margad., Taxon 9 : 51. 1960.

Fig. 23 A-G

Gametófitos robustos, verde-escuros. Filídios lanceolados, quando secos contorcidos, ápice acuminado, margem inteira, plana, células da base rombóides a quadráticas ou longo-retangulares, margem da base bordeada por várias camadas de células longas, parede celular delgada, não porosas. Filídios periqueciais iguais aos demais, caliptra decídua, plicada, glabra.

Material examinado: Minas Gerais, Conceição do Mato Dentro, O. Yano 529 (SP135485).

Ocorre nos estados de AL, AM, AP, BA, CE, MT, PA, PE, RJ, RO, RS, SE e SP. Na Serra do Cipó, cresce em tronco de árvore. Os gametófitos desta espécie apresentam o ápice dos filídios acuminados e comumente quebrados.

\section{Macrocoma (Müll. Hal.) Grout}

Gametófitos cladocárpicos, medianos, formando tapetes. Caulídios primários prostrados, tomentoso, ramos secundários ascendentes. Filídios lanceolados, planos, espiralados, quando secos imbricados. Costa única, percurrente, estreita, ápice do filídio agudo, margem do filídio plana, inteira, não bordeada, células da lâmina circulares, isodiamétricas, 


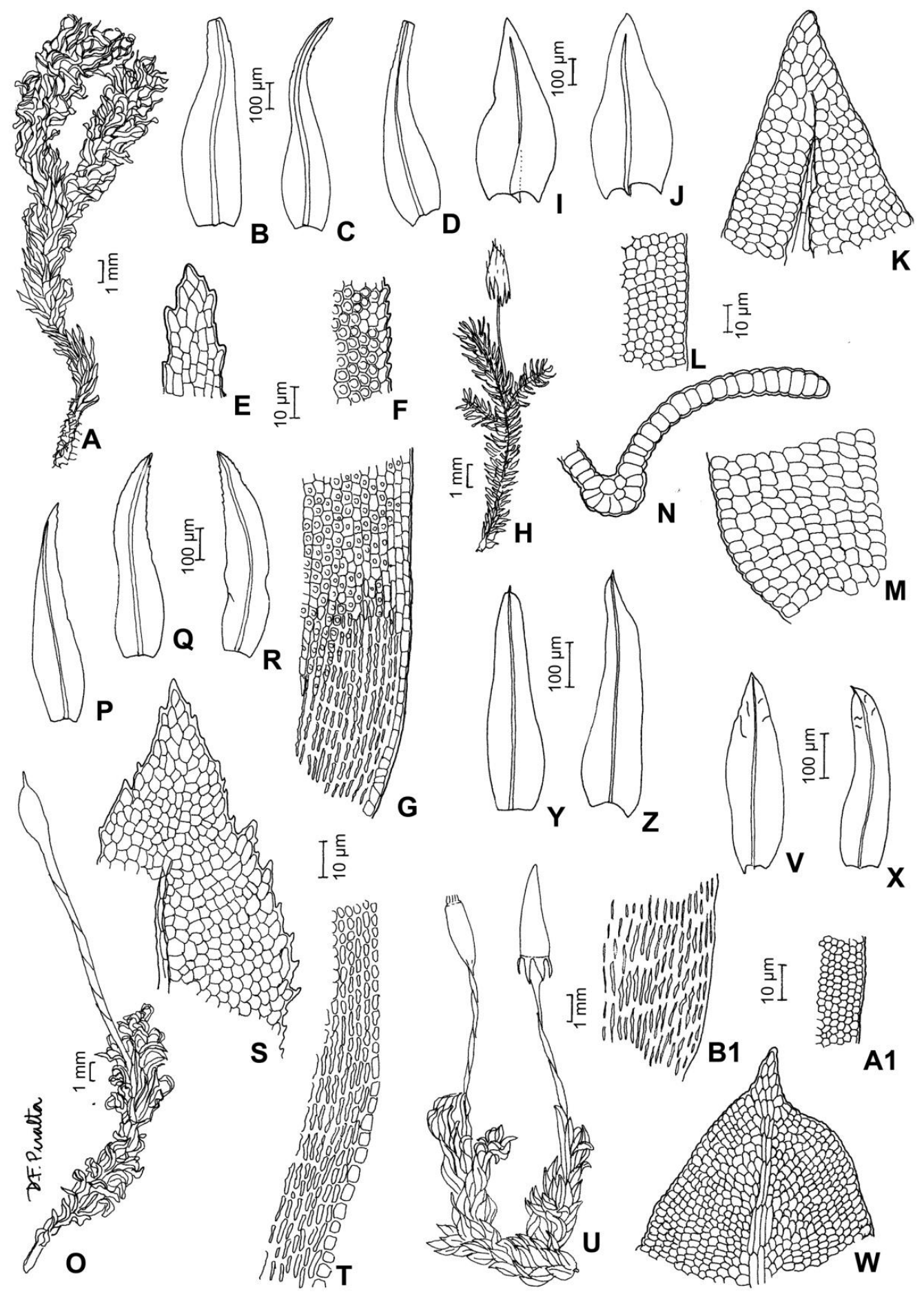

Fig. 23. Groutiella tomentosa (Hornsch.) Wijk \& Margad. A. aspecto do gametófito. B-D. filídios. E. células do ápice do filídio. F. células da margem do filídio. G células da base do filídio. Macrocoma frigida (Müll. Hal.) Vitt. H. aspecto do gametófito. I-J. filídios. K. células do ápice do filídio. L. células da margem do filídio. M. células da base do filídio. N. secção transversal do filídio. Macromitrium punctatum (Hook. \& Grev.) Brid. O. aspecto do gametófito. P-R. filídios. S. células do ápice do filídio. T. células da base do filídio. Schlotheimia jamesonii (W. Arnott) Brid. U. aspecto do gametófito. V-X. filídios. Y-Z. filídios periqueciais. W. células do ápice do filídio. A1. células da margem do filídio. B1. células da base do filídio (A-G. O. Yano 529; H-N. O. Yano \& Wanderley 10734 p.p.; O-T. O. Yano 503; U-B1. Pirani et al. 12356). 
lisas ou papilosas, parede celular espessada, reta, células da base do filídio mais claras, alongadas porém não infladas, filídios periqueciais pouco diferenciados. Seta longa, reta, lisa. Cápsula exserta, reta, simétrica, urna ovóide ou sub-cilíndrica, rômbica, superfície quando seca estriada, ânulo presente. Opérculo rostrado, peristômio duplo. Caliptra pequena, pilosa ou glabra.

2.1. Macrocoma frigida (Müll. Hal.) Vitt, Revue Bryol. Lichénol. n. sér. 39(2): 209. 1973.

Fig. $23 \mathrm{H}-\mathrm{N}$

Gametófitos estreitos e delicados, verdeescuros. Filídios lanceolados, quando secos imbricados, ápice agudo, margem inteira, plano, células da base rombóides a quadráticas, margem da base não bordeada por várias camadas de células lineares, parede celular espessada, não porosas. Filídios periqueciais iguais aos demais, caliptra persistente e cobrindo a cápsula, plicada, glabra.

Material examinado: Minas Gerais, Santana do Riacho, O. Yano \& Wanderley 10734 p.p., 10759 (SP220429; SP220453).
Associada a Schlotheimia rugifolia (Hook.) Schwägr. Ocorre nos estados de MG, RJ, RS e SP. $\mathrm{Na}$ Serra do Cipó, cresce em tronco vivo. Esta espécie quando comparada as demais da família apresenta os gametófitos muito delgados e ramificados.

\section{Macromitrium Brid.}

Gametófitos cladocárpicos, medianos ou robustos, formando tapetes. Caulídios primários prostrados, tomentosos, ramos secundários ascendentes. Filídios ligulados, planos ou crispados ou ondulados longitudinalmente (plicados), espiralados, quando secos crispados. Costa única, percurrente, estreita, ápice do filídio apiculado, obtuso ou agudo, margem do filídio plana, inteira, não bordeada, células da lâmina fusiformes ou circulares ou quadrático-irregulares, isodiamétricas, lisas ou mamilosas ou papilosas, parede celular espessada, reta, células da base do filídio mais claras, alongadas porém não infladas, filídios periqueciais pouco ou muito diferenciados. Seta longa, reta, torcida ou lisa. Cápsula exserta, ereta, simétrica, urna ovóide ou sub-cilíndrica, rômbica, superfície quando seca estriada, ânulo presente. Opérculo rostrado, peristômio duplo. Caliptra pequena, pilosa ou glabra.

Chave para as espécies

1. Ápice do filídio acuminado, margem denteada na porção distal, células da lâmina lisas

3.1. M. punctatum

1'. Ápice do filídio agudo a apiculado, margem inteira na porção distal, células da lâmina pluripapilosas

3.2. M. richardii

3.1. Macromitrium punctatum (Hook. \& Grev.) Brid., Bryol. Univ. 1: 739. 1826.

Fig. 23 O-T

Gametófitos robustos, verde-escuros. Filídios lanceolados, quando secos contorcidos, ápice acuminado, margem inteira ou denteada, plano, células da base longo-retangulares, margem da base não bordeada por várias camadas de células lineares, parede celular espessada, não porosas. Filídios periqueciais iguais aos demais, caliptra decídua, plicada, pilosa.

Material examinado: Minas Gerais, Conceição do Mato Dentro, O. Yano 503 (SP135466); Jaboticatubas, Piran et al. 6297 (SP43217, SPF); Santana do Riacho, O. Yano \& Wanderley 10666 (SP220361); Câmara 1892 (SP419640).

Ocorre nos estados de AL, AM, AP, BA, CE, ES, GO, MG, RJ, RS e SP. Na Serra do Cipó, cresce em tronco de árvore.
3.2. Macromitrium richardii Schwägr., Spec. Musc. Frond. Suppl. 2(2): 70. 173. 1826.

Fig. 23a A-I

Gametófitos medianos, verde-escuros. Filídios lanceolados, quando secos contorcidos, ápice agudo, margem inteira, plano, células da lâmina pluripapilosas, células da base longo-retangulares, gutuladas, margem da base não bordeada por várias camadas de células lineares, parede celular espessada, porosas. Filídios periqueciais iguais aos demais, caliptra decídua, plicada, pilosa.

Material examinado: Minas Gerais, Santana do Riacho, Pirani et al. 5693 (SP432336, SPF).

Ocorre nos estados de AL, AM, BA, CE, ES, MG, PR, RJ, RS, SC, SP. Na Serra do Cipó, cresce em tronco de árvore. 

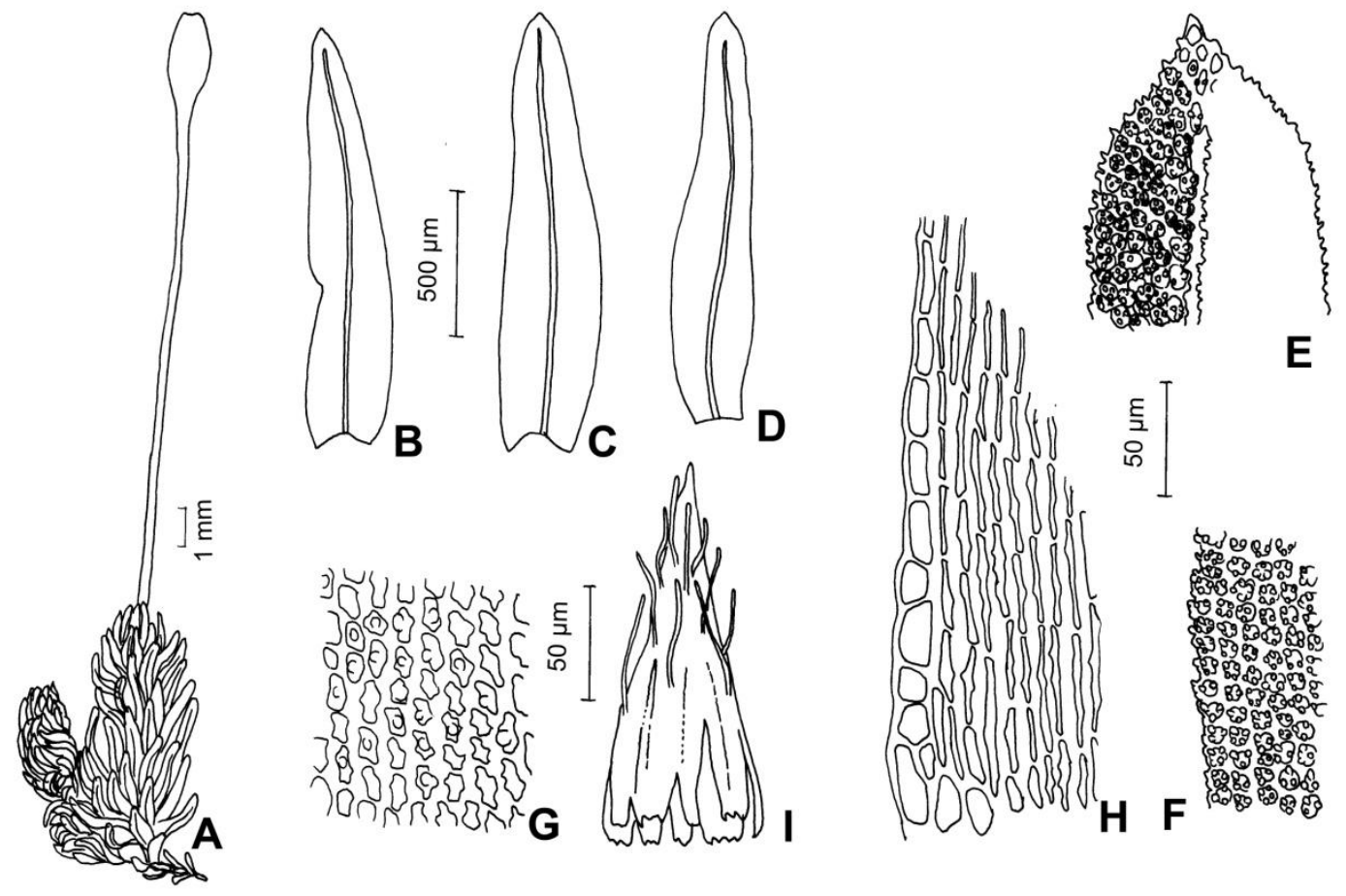

Fig. 23a. Macromitrium richardii Schwägr. B-D. filídios. E. detalhe das células do ápice do filídio. F. detalhe das células da margem do filídio. G. detalhe das células na região mediana do filídio. H. detalhe das células da base do filídio. I. caliptra (A-I. Pirani et al. 5693).

\section{Schlotheimia Brid.}

Gametófitos cladocárpicos, medianos ou robustos, formando tapetes. Caulídios primários prostrados, tomentosos, ramos secundários ascendentes. Filídios ligulados ou lanceolados, planos ondulados longitudinalmente (plicados), espiralados, quando secos crispados. Costa única, percurrente, estreita, ápice do filídio apiculado ou obtuso ou agudo, margem do filídio plana, inteira, denticulada ou denteada, não bordeada, células da lâmina fusiformes, isodiamétricas, lisas ou mamilosas, parede celular espessada, reta, células da base do filídio mais claras, alongadas porém não infladas, filídios periqueciais pouco diferenciados ou diferenciados. Seta curta ou longa, reta, torcida ou lisa. Cápsula exserta ou imersa, ereta, simétrica, sub-cilíndrica, rômbica, superfície quando seca estriada, ânulo presente. Opérculo rostrado, peristômio duplo. Caliptra pequena.

1. Lâmina do filídio plana.

2. Ápice acuminado; margem denteada; filídios lanceolados. 4.3. S. tecta

2'. Ápice agudo; margem inteira; filídios ligulados 4.1 S. jamesonii

1'. Lâmina do filídio plicada transversalmente.

3. Filídios periqueciais iguais aos demais; caliptra glabra

3 '. Filídios periqueciais diferenciados, maiores (ca. 1,5-2x); caliptra pilosa 4.4. S. trichomitria 
4.1. Schlotheimia jamesonii (W. Arnott) Brid., Bryol. Univ. 1: 742.1826.

Fig. 23 U-B1

Gametófitos robustos, marrom-avermelhados. Filídios ligulados, quando secos contorcidos, ápice agudo, margem inteira, plano, células da base longoretangulares, margem da base não bordeada por várias camadas de células lineares, parede celular espessada, porosa. Filídios periqueciais diferenciados, maiores (ca. 1,5-2x), caliptra persistente e cobrindo a cápsula, lisa, glabra.

Material examinado: Minas Gerais, Santana do Riacho, Pirani et al. 12356 (SP386338, SPF); Câmara 1947 p.p. (SP419660); Câmara et al. 2111 (SP419714); Dias Neto 177, 179, 181, 204, 249, 265, 266, 286 (SP419794; SP419796; SP419797; SP419811; SP419832; SP419843; SP419844; SP419852).

Associada a Herbertus bivittatus Spruce. Ocorre nos estados de BA, CE, DF, ES, GO, MA, MG, MS, PE, PR, RJ, RS, SC, SP e TO. Na Serra do Cipó, cresce em rocha e tronco vivo.

4.2. Schlotheimia rugifolia (Hook.) Schwägr., Spec. Musc. Frond. Suppl. 2(1): 150. 1824.

Fig. $24 \mathrm{~A}-\mathrm{H}$

Gametófitos robustos, marrom-avermelhados. Filídios ligulados, quando secos contorcidos, ápice agudo, margem inteira, enrugado, células da base longo-retangulares, margem da base não bordeada por várias camadas de células lineares, parede celular espessada, porosa. Filídios periqueciais iguais aos demais, caliptra persistente e cobrindo a cápsula, lisa, glabra.

Material examinado: Minas Gerais, Conceição do Mato Dentro, Oliveira Filho 1 (SP90866); Congonhas do Norte, Serra do Carapina Pirani et al. 4125 (SP284248, SPF170918); Dias Neto 148 (SP419775); Dias Neto 184 (SP419799); Santana do Riacho, Zappi et al. 10333 (SP230725, SPF170921); Pirani et al. 10378, 12299 p.p., 12302 p.p., 12355 (SP230730, SPF170928; SP386340, SPF; SP386341, SPF; SP386339, SPF); O. Yano \& Wanderley 10734 p.p., 10769, 10791p.p. (SP220429; SP220463; SP220484); Câmara et al. 2027 (SP419696).

Associada a Frullania brasiliensis Raddi, Macrocoma frigida (Müll. Hal.) Vitt e Plagiochila corrugata (Nees) Nees \& Mont. Ocorre nos estados de $A C, A L, B A, D F, E S, M G, P E, R J, S P, G O, P A, R O$,
CE, AM, PR, SC, MT, RS e TO. Na Serra do Cipó, cresce em tronco vivo. Esta é uma espécie muito característica pelos filídios muito rugosos e muito colorido de vermelho.

4.3. Schlotheimia tecta Hook. f. \& Wilson, London J. Bot. 3: 157. 1844.

Fig. 24 I-N

Gametófitos robustos, marrom-avermelhados. Filídios lanceolados, quando secos contorcidos, ápice acuminado, margem denteada, plano, células da base longo-retangulares, margem da base não bordeada por várias camadas de células lineares, parede celular espessada, porosa. Filídios periqueciais diferenciados, maiores (ca. 1,5-2x), caliptra persistente e cobrindo a cápsula, lisa, glabra.

Material examinado: Minas Gerais, Santana do Riacho, Câmara 1991a (SP419686).

Ocorre nos estados de BA, CE, ES, MG, PE, PR, RJ, RS, SC e SP. Na Serra do Cipó, cresce em tronco. Dentre as espécies que foram encontradas deste gênero esta é a que apresenta o hábito mais robusto e o único com a margem do filídio denteada.

4.4. Schlotheimia trichomitria Schwägr., Spec. Musc. Frond. Suppl. 2(2): 55. 1826.

Fig. $24 \mathrm{O}-\mathrm{V}$

Gametófitos robustos, marrom-avermelhados. Filídios ligulados, quando secos contorcidos, ápice agudo, margem inteira, enrugado, células da base longo-retangulares, margem da base não bordeada por várias camadas de células lineares, parede celular espessada, porosa. Filídios periqueciais diferenciados, maiores (ca. 1,5-2x), caliptra persistente e cobrindo a cápsula, pilosa.

Material examinado: Minas Gerais, Conceição do Mato Dentro, Vital 1226, 1232 (SP88727; SP88500); Câmara 1954 (SP419667); Dias Neto 194, 206 (SP419805; SP419812); Santana do Riacho, Pirani et al. 6027 (SP432372, SPF).

Ocorre nos estados de BA, ES, GO, MG, PR, RJ, SC e SP. Na Serra do Cipó, cresce em tronco. A presença de tricomas na caliptra desta espécie é uma característica muito distintiva e de fácil identificação. 


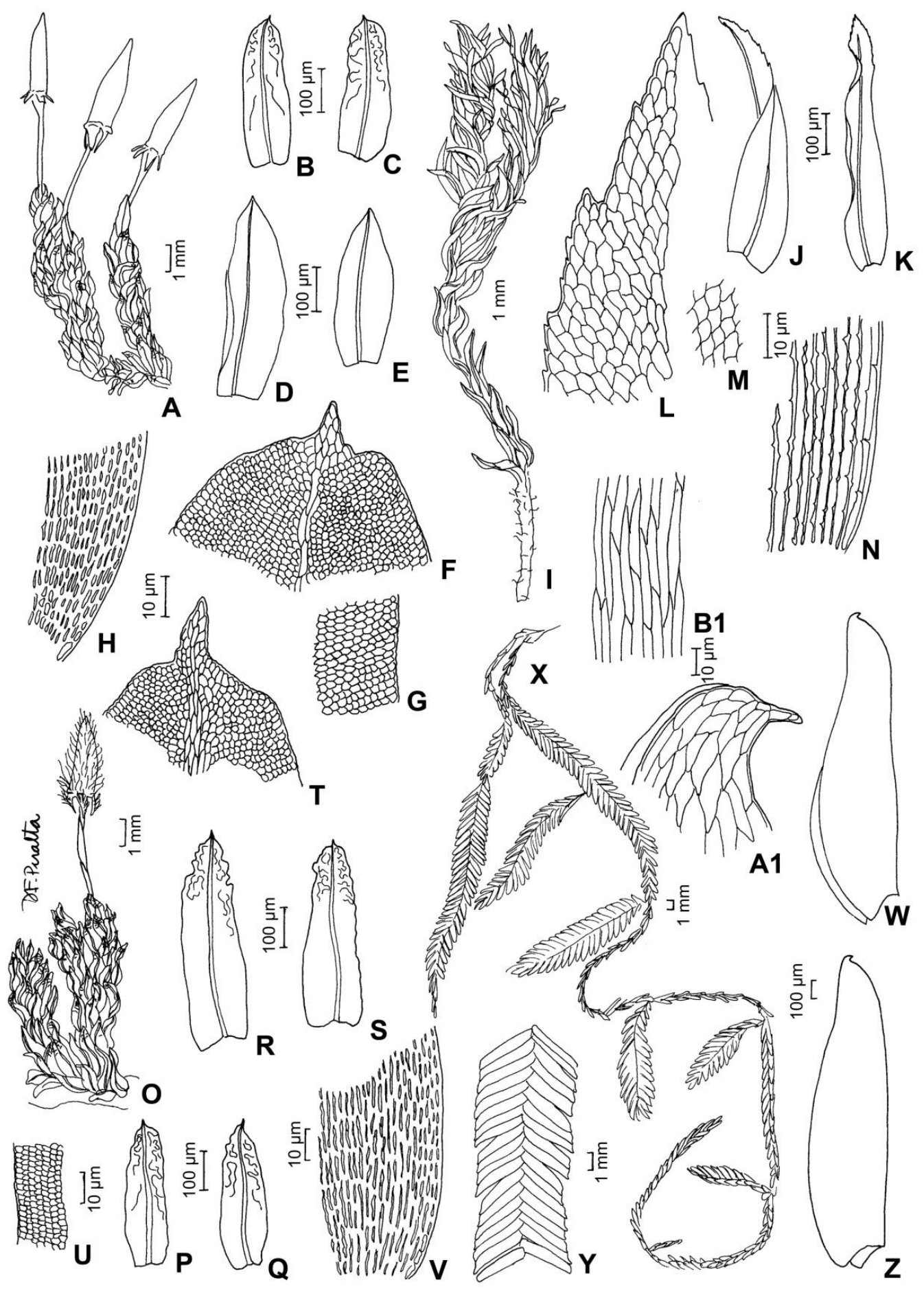

Fig. 24. Schlotheimia rugifolia (Hook.) Schwägr. A. aspecto do gametófito. B-C. filídios. D-E. filídios periqueciais. F. células do ápice do filídio. G. células da margem do filídio. H. células da base do filídio. Schlotheimia tecta Hook. f. \& Wilson. I. aspecto do gametófito. J-K. filídios. L. ápice do filídio. M. células da lâmina do filídio. N. células da base do filídio. Schlotheimia trichomitria Schwägr. O. aspecto do gametófito. P-Q. filídios. R-S. filídios periqueciais. T. células do ápice do filídio. U. células da margem do filídio. V. células da base do filídio. Phyllogonium viride Brid. X. aspecto do gametófito. Y. detalhe da disposição dos filídios. W-Z. filídios. A1. células do ápice do filídio. B1. células da lâmina do filídio (A-H. Oliveira Filho 1; I-N. Câmara 1991a; O-V. Vital 1226; X-B1. Pirani et al. 5635). 


\section{Phyllogoniaceae}

É uma família bastante comum no Brasil, principalmente em áreas de Floresta Atlântica, caracterizada principalmente pela disposição dística dos filídios e o hábito pendente. Ocorre principalmente como corticícola. No Brasil ocorre apenas o gênero Phyllogonium e duas espécies, uma delas ocorrendo na Serra do Cipó.

Bibliografia básica - Gradstein et al. (2001); Sharp et al. (1994); Yano \& Mello (1989).

\section{Phyllogonium Brid.}

Gametófitos pleurocárpicos, formando tufos. Caulídios primários prostrados, tomentosos, ramos secundários pendentes, pseudoparáfilos lisos. Filídios ovados, marcadamente assimétricos, canaliculados, dísticos, quando secos imbricados, base do filídio auriculada. Costa dupla, curta, ca. 1/10 a 1/20 do compr., estreita, ápice do filídio apiculado, margem do filídio plana, inteira, não bordeada, células da lâmina lineares, lisas, parede celular espessada, porosa, células da base do filídio 1 . 10 fileira de células, muito infladas, marrons a laranja. Seta curta, reta. Cápsula exserta ou imersa, ereta, simétrica, urna ovóide ou sub-cilíndrica, rômbica, superfície lisa quando seca. Opérculo rostrado, peristômio duplo. Caliptra glabra.

1.1 Phyllogonium viride Brid., Bryol. Univ. 2: 673. 1827.

Fig. $24 \mathrm{X}-\mathrm{C} 1$

Gametófitos robustos, formando tufos. Caulídios primários prostrados, secundários pendentes. Filídios ovados, canaliculados, dísticos, quando secos imbricados, base do filídio auriculada. Costa dupla, curta, ca. 1/10 a 1/20 do compr., estreita, ápice do filídio apiculado, recurvado, células da lâmina lineares, lisas, parede celular espessada, porosa, células da base infladas, marrons a laranja. Seta curta, reta. Cápsula imersa, ereta, simétrica, urna ovóide ou sub-cilíndrica, rômbica, superfície lisa quando seca. Opérculo rostrado, peristômio duplo. Caliptra glabra.

Material examinado: Minas Gerais, Congonhas do Norte, Pirani et al. 5635 (SP389353; SPF); Câmara 1937 (SP419656).

Ocorre nos estados de AL, BA, CE, ES, MG, PE, PR, RJ, RS, SC e SP. Na Serra do Cipó, cresce em tronco.

\section{Pilotrichaceae}

Gametófitos pleurocárpicos, medianos ou robustos, formando tapetes. Caulídios primários prostrados, ramos secundários ascendentes ou prostrados. Filídios ligulados, lanceolados ou ovados, em alguns gêneros diferenciados em laterais e ventrais, assimétricos ou simétricos, planos ou ondulados transversalmente, aplainados ou espiralados, base simples, ápice obtuso, pilífero ou agudo, margens planas, denticuladas, não bordeado ou bordeado. Costa dupla até $1 / 2$ ou $3 / 4$ compr. do filídio ou percurrente. Células da lâmina fusiformes, longo-hexagonais ou hexagonais, lisas ou papilosas, parede celular delgada, reta, região alar iguais as da lâmina. Dióicos, monóicos ou autóicos. Seta presente, longa, reta, avermelhada, rugosa, espinhosa ou lisa. Cápsula exserta, pêndula ou ereta, assimétrica, urna ovóide. Rômbica. Superfície quando seca lisa. Pescoço distinto mas sem diferenciação. Ânulo presente. Peristômio duplo. Caliptra pilosa ou glabra, não plicada.

É uma família amplamente distribuída no Brasil, caracterizada principalmente pela costa dupla e longa. Ocorre principalmente como corticícola, terrestre e saxícola. Para a identificação das espécies é necessário análise da morfologia das células da lâmina do filídio e do esporófito. No Brasil ocorrem 15 gêneros e 107 espécies; na Serra do Cipó ocorrem dois gêneros e duas espécies.

Bibliografia básica - Gradstein et al. (2001); Sharp et al. (1994); Vaz \& Costa (2006); Yano \& Peralta (2009). 
Flora da Serra do Cipó, Minas Gerais: Briófitas (Anthocerotophyta, Bryophyta e Marchantiophyta)

\section{Callicostella (Müll. Hal.) Mitt.}

Gametófitos pleurocárpicos, medianos, formando tapetes. Caulídios primários prostrados, poucos rizóides, ramos secundários prostrados. Filídios ligulado a ovados. Filídios de dois formatos laterais e ventral, marcadamente assimétricos, planos, aplainados ou espiralados, quando secos crispados ou planos. Costa dupla, 1/2 ou 3/4 compr. do filídio, estreita, ápice do filídio obtuso, margem do filídio plana, denticulada, não bordeada, células da lâmina fusiformes, hexagonais, lisas ou papilosas, parede celular delgada, reta, células da base do filídio iguais as da lâmina. Seta longa, reta, rugosa ou espinhosa ou lisa. Cápsula exserta, pêndula ou ereta, assimétrica, urna ovóide, rômbica, superfície lisa quando seca, ânulo presente. Opérculo rostrado, peristômio duplo. Caliptra pequena, pilosa ou glabra.

1.1. Callicostella pallida (Hornsch.) Ångstr., Öfvers. Kongl. Svenska Vetensk.-Akad. 33(4): 27. 1876.

Fig. $25 \mathrm{~A}-\mathrm{G}$

Gametófitos verde-escuros, irregularmente pinados; filídios oblongos, ápice amplamente obtusomucronado a agudo, margem inteira, dentículos irregulares na região apical, base assimétrica; costa dupla subpercurrente, células superiores papilosas, quadráticas a rombo-hexagonais, células basais retangulares.

Material examinado: Minas Gerais, Conceição do Mato Dentro, O. Yano 480 p.p., 488 p.p., 485, 487, 489, 508, 527, 531 (SP135452; SP132041; SP135454; SP135456; SP135457; SP135470; SP135483; SP135487); Oliveira Filho 3 (SP90865); Santana do Riacho, O. Yano \& Wanderley 10646 p.p., 10652,10665 p.p., 10680 p.p., 10849, 10860 (SP220341; SP220347; SP220360; SP220375; SP220542; SP220553); Pirani et al. 5545 (SP 388844, SPF); Dias Neto 114 (SP419750).

Associada a Isopterygium tenerifolium Mitt., Lejeunea phyllobola Nees \& Mont., Philonotis sphaerocarpa (Hedw.) Brid., Rolulabryum huillense (Wilw. \& Duby) Ochyra, Sematophyllum galipense (Müll. Hal.) Mitt., S. subsimplex (Hedw.) Mitt. e Telaranea nematodes (Gottsche ex Austin) M. Howe. Ocorre nos estados de AC, AL, AM, AP, BA, CE, DF, ES, GO, MG, MS, MT, PA, PE, PR, RJ, RR, RS, RO, SE, SP e TO. Na Serra do Cipó, cresce em solo e rocha. Esta é uma espécie bastante comum em áreas de mata de galeria, e facilmente diferençável das demais espécies do gênero pela células da lâmina unipapilosas.

\section{Trachyxiphium W.R. Buck}

Gametófitos pleurocárpicos, medianos, formando tapetes. Caulídios primários prostrados, poucos rizóides, ramos secundários prostrados. Filídios lanceolados, marcadamente assimétricos, planos, aplainados, planos quando secos. Costa dupla, $1 / 2$ ou $3 / 4$ compr. do filídio, estreita, ápice do filídio agudo, margem do filídio plana, denticulada, não bordeada, células da lâmina fusiformes ou longohexagonais, lisas, parede celular delgada, reta, células da base do filídio iguais as da lâmina. Seta longa, reta, lisa. Cápsula exserta, pêndula ou ereta, assimétrica. Opérculo rostrado, peristômio duplo. Caliptra pequena.

2.1. Trachyxiphium saxicola (R.S. Williams) VazImbassahy \& Costa, Nova Hedwigia 88(3-4): 472. 2009.

Fig. $25 \mathrm{H}-\mathrm{M}$

Gametófitos verde-amarelados. Filídios lanceolados, ápice acuminado, margem duplodenticulada, base simétrica, costa dupla, 2/3 compr., células da lâmina lisas.

Material examinado: Minas Gerais, Conceição do Mato Dentro, O. Yano 534 (SP135489).

Ocorre nos estados de AL, CE, MG, MT, RJ, RS e SP. Na Serra do Cipó, cresce em rocha. Esta é uma espécie facilmente diferençável pelas células da margem fortemente duplo denteadas e a costa também denteada ventralmente.

\section{Polytrichaceae}

Gametófitos acrocárpicos, medianos ou robustos, formando tufos. Caulídios primários prostrados, tomentosos, ramos secundários ascendentes. Filídios lanceolados, canaliculados, espiralados, quando secos imbricados, base vaginante. Costa única, percurrente, larga, secção transversal camada de estereídios distinta, lamelas ventrais, ápice acuminado, margens involuta ou plana, inteira ou denteada. Células da lâmina quadrático irregulares, isodiamétricas, lisas, parede celular espessada, reta, na região alar mais claras e alongadas porém não infladas. Dióicos ou monóicos. Seta presente longa, reta, marrom-dourada, lisa. Cápsula exserta, pêndula ou ereta, simétrica, urna subcilíndrica, angulosa. Peristômio nematodôntico. Caliptra grande e cobrindo a cápsula após o desenvolvimento, pilosa, não plicada. 


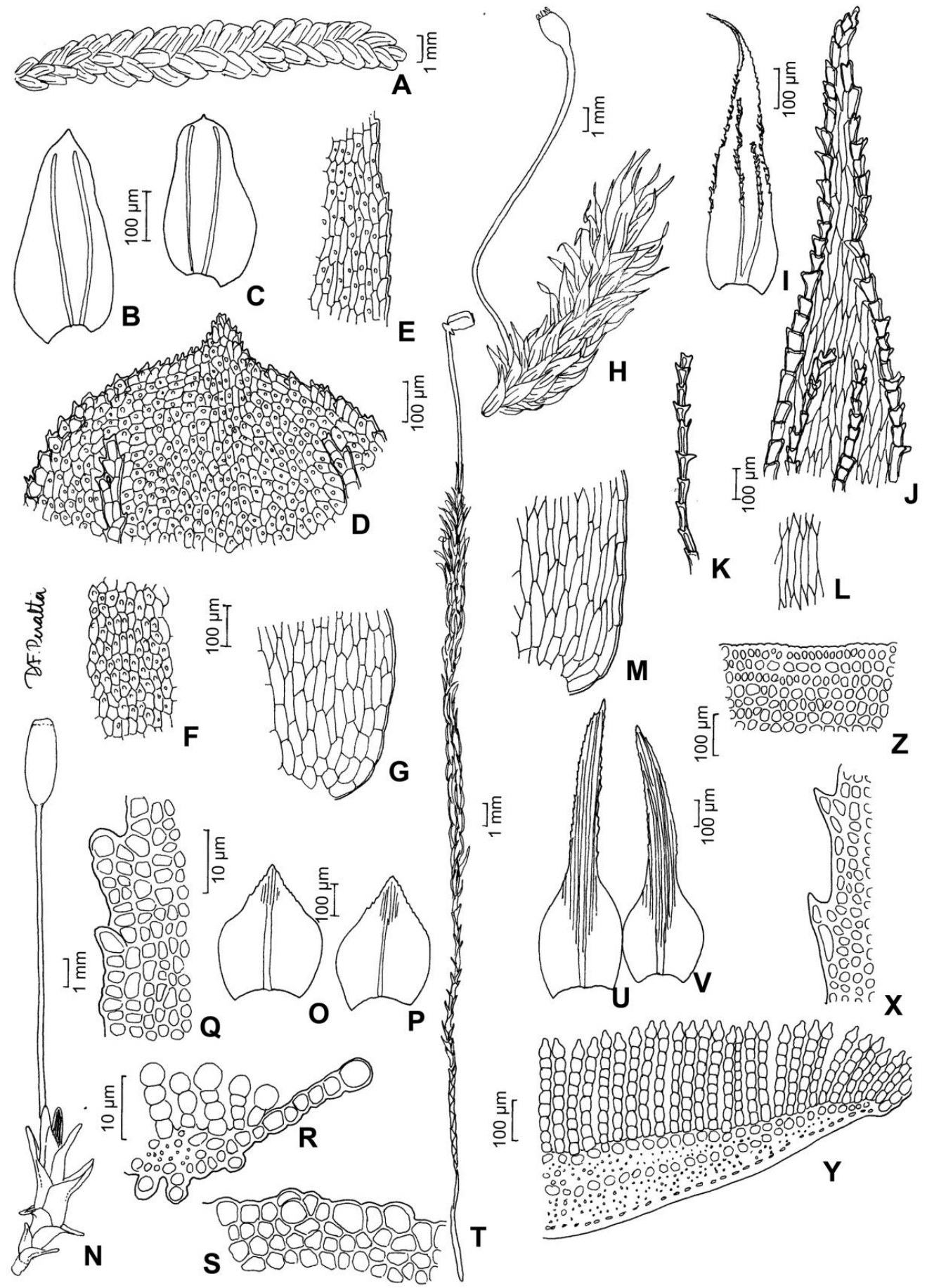

Fig. 25. Callicostella pallida (Hornsch.) Ăngstr. A. aspecto do gametófito. B-C. filídios. D. células do ápice do filídio. E. células da margem do filídio. F. células da lâmina do filídio. G. células da base do filídio. Trachyxiphium saxicola (R.S. Williams) VazImbassahy \& Costa. H. aspecto do gametófito. I. filídio. J. células do ápice do filídio. K. células da margem do filídio. L. células da lâmina do filídio. M. células da base do filídio. Pogonatum pensilvanicum (Hedw.) P. de Beauv. N. aspecto do gametófito. OP. filídios periqueciais. Q. células da margem do filídio. R. secção transversal do filídio. S. lamela em vista lateral. Polytrichum angustifolium Mitt. T. aspecto do gametófito. U-V. filídios. X. células da margem do filídio. Y. secção transversal do filídio. Z. lamela em vista lateral (A-G. O. Yano 485; H-M. O. Yano 534; N-S. Vital 1236; T-Z. Pirani et al. 5023). 
Flora da Serra do Cipó, Minas Gerais: Briófitas (Anthocerotophyta, Bryophyta e Marchantiophyta)

É uma família amplamente distribuída no Brasil, principalmente relacionada as áreas de planalto, caracterizada principalmente pelo hábito ereto e robusto e pelas lamelas ventrais no filídio. Ocorre principalmente como terrestre e rupícola. Para a identificação das espécies é necessário análise da secção do filídios na região da costa.
No Brasil ocorrem oito gêneros e 16 espécies; na Serra do Cipó ocorrem dois gêneros e quatro espécies.

Bibliografia básica - Gradstein et al. (2001); Peralta \& Yano (2010); Sharp et al. (1994); Yano \& Peralta (2009).

Chave para os gêneros

1. Esporófito sem constrição na base da cápsula, célula apical da lamela circular

1'. Esporófito com constrição na base da cápsula, célula apical da lamela não circular, piriforme ou em

formato de $\mathrm{U}$

1. Pogonatum

2. Polytrichum

\section{Pogonatum P. Beauv.}

Gametófitos acrocárpicos, pequenos a medianos, formando tufos. Caulídios primários prostrados, tomentosos, ramos secundários ascendentes. Filídios lanceolados, canaliculados, espiralados, quando secos imbricados, base do filídio bainha vaginante. Costa única, percurrente, larga (2/3 a $3 / 4$ da largura do filídio), secção transversal com camada de estereídios distinta, lâmina do filídio lamelas ventrais, ápice do filídio acuminado, margem do filídio plana, denteada, não bordeada, células da lâmina quadrático-irregulares, isodiamétricas, lisas, parede celular espessada, reta, células da base do filídio mais claras, alongadas porém não infladas. Seta longa, reta. Cápsula ereta, assimétrica, urna subcilíndrica. Opérculo rostrado. Peristômio nematodôntico. Caliptra grande e cobrindo a cápsula após o desenvolvimento, pilosa.

1.1. Pogonatum pensilvanicum (Hedw.) P. de Beauv., Mem. Soc. Linn. Paris 1: 461. 1823.

Fig. $25 \mathrm{~N}-\mathrm{R}$

Gametófitos efêmeros, protonema persistente, caulídio ereto. Filídios lanceolados, base vaginante, margem denteada, ápice acuminado, costa 4-14 lamelas fotossintetizantes, 2-3 cél. alt. (cada), célula apical arredondada, lisa, cápsula sem constrição na base.
Material examinado: Minas Gerais, Conceição do Mato Dentro, Vital 1236 (SP88502); Santana do Riacho, O. Yano \& Wanderley 10664 (SP220259).

Ocorre nos estados de BA, DF, ES, GO, MG, PR, RJ, RS, SC e SP. Na Serra do Cipó, cresce em rocha e solo.

\section{Polytrichum Hedw.}

Gametófitos acrocárpicos, medianos ou robustos, formando tufos. Caulídios primários prostrados, tomentosos, ramos secundários ascendentes. Filídios lanceolados, canaliculados, espiralados, quando secos imbricados, base do filídio bainha vaginante. Costa única, percurrente, larga (2/3 a 3/4 da largura do filídio), secção transversal com camada de estereídios distinta, lâmina do filídio lamelas ventrais, ápice do filídio acuminado, margem do filídio involuta ou encurvada ou plana, denteada, não bordeada, células da lâmina quadráticoirregulares, isodiamétricas, lisas, parede celular espessada, reta, células da base do filídio mais claras, alongadas porém não infladas. Seta longa, reta. Cápsula exserta, ereta, simétrica, urna sub-cilíndrica. Opérculo rostrado. Peristômio nematodontoide. Caliptra grande e cobrindo a cápsula após o desenvolvimento, pilosa.

Chave para as espécies

1. Lâmina do filídio cobrindo a superfície adaxial da lâmina

1'. Lâmina do filídio ereta, não cobrindo a superfície adaxial da lâmina.

2. Células apicais da lamela em secção transversal piriformes

2.3. P. juniperinum

2 '. Células apicais da lamela em secção transversal em formato de $U$ 
2.1. Polytrichum angustifolium Mitt., J. Linn. Soc. Bot. 12: 622. 1869.

Fig. $25 \mathrm{~T}-\mathrm{Z}$

\author{
Gametófitos robustos. Filídios linear- \\ lanceolados, costa com até 65 lamelas \\ fotossintetizantes, 5-10 células de alt. (cada); célula \\ apical piriforme, rugosa, margem denteada.
}

Material examinado: Minas Gerais, Santana do Riacho, Pirani et al. 5023, 6028 (SP361917, SPF; SP432373, SPF).

Ocorre nos estados de BA, ES, MG, PR, RJ, RR, RS, SC e SP. Na Serra do Cipó, cresce em solo. Esta espécie é a que possui o hábito mais robusto das espécies que ocorrem no Brasil.

2.2. Polytrichum commune Hedw., Spec. Musc. Frond.: 88. 1801.

Fig. 26 A-F

Gametófitos robustos. Filídios linearlanceolados, costa com até 50 lamelas fotossintetizantes, 3-9 células de altura, célula apical da lamela em formato de $\mathrm{U}$, lisa, margem denteada.

Material examinado: Minas Gerais, Conceição do Mato Dentro, Vital 1235 (SP88501); Santana do Riacho, O. Yano \& Wanderley 10698 (SP220393); Pirani et al. 5023, 5493, 12103 (SPF170933; SP388839, SPF; SPF170931).

Ocorre nos estados de AM, BA, DF, GO, MG, PR, RJ, RR, RS, SC e SP. Na Serra do Cipó, cresce em rocha e solo. Quando cresce diretamente exposto ao sol os gametófitos ficam bastante semelhantes a $P$. angustifolium, porém a secção transversal do filídio é decisiva.

2.3. Polytrichum juniperinum Willd. ex Hedw., Spec. Musc. Frond.: 89. 1801.

Fig. 26 G-L

Gametófitos medianos a robustos. Filídios linearlanceolados, costa com até 40 fileiras de lamelas fotossintetizantes de 4-7 células alt. (cada), a terminal piriforme; margem inteira, larga, fortemente involuta dobrada acima dos ombros, recobrindo a costa.

Material examinado: Minas Gerais, Conceição do Mato Dentro, Vital 1245, 1256 (SP88562; SP88563); O. Yano
513, 521 (SP135473; SP135479); Pirani et al. 5570 (SP389349; SPF); Congonhas do Norte, Serra da Carapina, Rapini et al. 527 (SP284249); Pirani et al. 4124, 5124, 5580 (SP284250, SPF170932; SPF; SP 379506; SP389351; SPF); Santana do Riacho, Pirani et al. 5508, 6029, 10379, 11919 (SP388840, SPF; SP432374, SPF; SP230729, SPF170929; SPF170930); Câmara 1962, 1972 (SP419674; SP419680); Dias Neto 182, 208 (SP419798; SP419814).

Ocorre nos estados de BA, DF, ES, GO, MG, PR, RJ, RR, RS, SC, SP e TO. Na Serra do Cipó, cresce em solo e rocha. Esta espécie é fácil de identificar apenas com o auxílio de lupa de mão, pois é a única das espécies desta família que ocorre no Brasil que apresenta a margem involuta e com aspecto membranáceo.

\section{Pottiaceae}

Gametófitos acrocárpicos, pequenos e delicados ou medianos, formando tufos. Caulídios primários prostrados, ramos secundários ausentes ou raros. Filídios ligulados ou lanceolados, planos, espiralados, quando secos crispados, base simples, ápice apiculado, obtuso ou agudo, margens do filídio plana, revoluta ou involuta, inteira, não bordeada. Costa única, percurrente ou excurrente, estreita, secção transversal camada de estereídios distinta. Células da lâmina quadrático irregulares, isodiamétricas, lisas, mamilosas ou papilosas, parede celular espessada ou delgada, reta, região alar mais claras e alongadas porém não infladas. Dióicos ou monóicos. Seta curta ou longa, reta, marrom-dourada, torcida ou lisa. Cápsula exserta ou imersa, ereta, simétrica, urna piriforme, ovóide ou subcilíndrica, rômbica. Peristômio ausente ou único. Caliptra pequena, glabra, não plicada.

É uma família amplamente distribuída no Brasil, caracterizada principalmente pelo aspecto muito contorcido quando seco, costa forte e células pequenas e isodiamétricas. Ocorre principalmente como terrestre, rupícola e áreas antropizadas. Para a identificação das espécies é necessário análise da morfologia da secção transversal da costa e das células da lâmina do filídio. No Brasil ocorrem 44 gêneros e 123 espécies; na Serra do Cipó ocorrem quatro gêneros e quatro espécies.

Bibliografia básica - Gradstein et al. (2001); Sharp et al. (1994); Yano \& Peralta (2009); Zander (1993). 
Flora da Serra do Cipó, Minas Gerais: Briófitas (Anthocerotophyta, Bryophyta e Marchantiophyta)

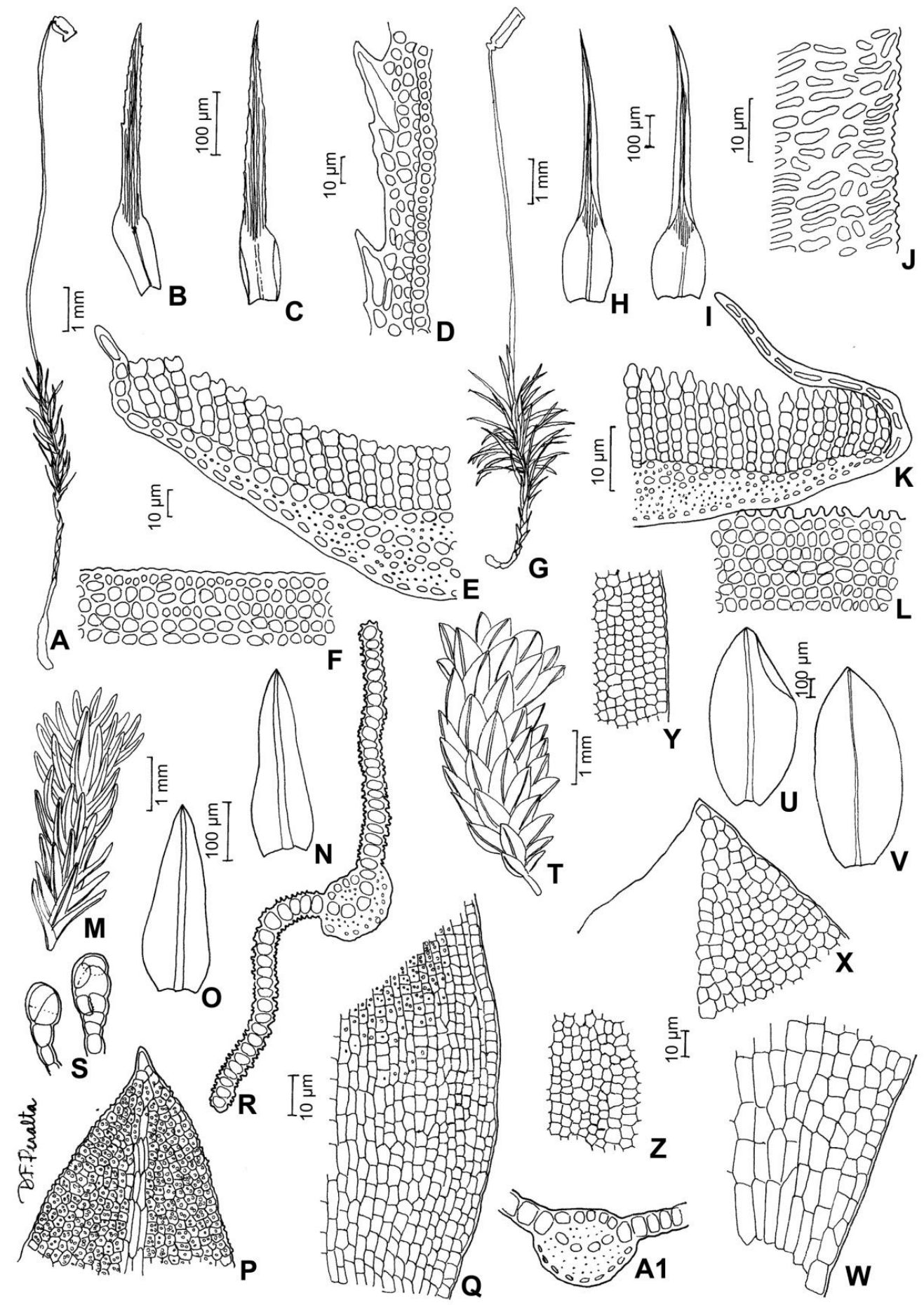

Fig. 26. Polytrichum commune Hedw. A. aspecto do gametófito. B-C. filídios. D. células da margem do filídio. E. secção transversal do filídio. F. lamela em vista lateral. Polytrichum juniperinum Willd. ex Hedw. G. aspecto do gametófito. H-I. filídios. J. células da margem do filídio. K. secção transversal do filídio. L. lamela em vista lateral. Barbula indica (Hook.) Spreng. ex Steudel. M. aspecto do gametófito. N-O. filídios. P. células do ápice do filídio. Q. células da base do filídio. R. secção transversal do filídio. S. gemas axilares. Hyophila involuta (Hook.) A. Jaeger. T. aspecto do gametófito. U-V. filídios. X. células do ápice do filídio. Y. células da margem do filídio. Z. células da lâmina do filídio. W. células da base do filídio. A1. secção transversal da costa do filídio (A-F. Vital 1235; G-L. Vital 1245; M-S. Câmara 1943; T-A1. Pirani et al. 5571). 
1. Filídios lanceolados, margens dos filídios planas a incurvadas, costa curto-excurrente, em secção transversal sem hidróides.

2. Células da base mais longas e largas, parede delgada e incolor, região basal em formato de $\mathrm{V}$, lâmina plana

2'. Células da base pouco diferenciadas das superiores, parede espessada, região basal pouco pronunciada e não em formato de $\mathrm{V}$, lâmina incurvada

3. Tortella

ilídios ligulados a lanceolados, margens dos filídios planas a

secção transversal com hidróides.

3. Peristômio ausente, células lisas

3'. Peristômio presente, células pluripapilosas

2. Hyophila

1. Barbula

\section{Barbula Hedw.}

Gametófitos acrocárpicos, pequenos, delicados, formando tufos. Caulídios primários eretos, poucos rizóides, ramos secundários ausentes ou raros. Filídios lanceolados, planos, espiralados, planos quando secos. Costa única, subpercurrente, estreita, secção transversal com camada de estereídios distinta, ápice do filídio apiculado, agudo, margem do filídio revoluta, margem inteira, não bordeada, células da lâmina quadrático-irregulares, isodiamétricas, papilosas, parede celular espessada, reta, células da base do filídio mais claras, alongadas porém não infladas. Reprodução vegetativa por gemas. Seta longa, reta, lisa. Cápsula exserta, ereta, simétrica, urna sub-cilíndrica, rômbica, superfície lisa quando seca. Opérculo rostrado. Peristômio simples. Caliptra glabra.

1.1. Barbula indica (Hook.) Spreng. ex Steudel., Nomencl. Bot. 2: 72.1824.

Fig. 26 M-S

Gametófitos pequenos, delicados, formando tufos. Caulídios primários eretos. Filídios lanceolado. Costa única, subpercurrente, estreita, secção transversal com camada de estereídios distinta, ápice do filídio apiculado, agudo, margem do filídio revoluta, margem inteira, células da lâmina quadráticoirregulares, papilosas, parede celular espessada, reta, células da base do filídio mais claras, alongadas porém não infladas. Seta longa, reta, lisa. Cápsula exserta, ereta, simétrica, urna sub-cilíndrica, rômbica, superfície lisa quando seca. Opérculo rostrado. Peristômio simples. Caliptra glabra.

Material examinado: Minas Gerais, Santana do Riacho, Câmara 1943 (SP419658); Dias Neto 136 (SP419766).

Ocorre nos estados do AC, AM, BA, DF, ES, GO, MG, MS, MT, PA, RJ, RS e SP. Na Serra do Cipó, cresce em solo. Os gametófitos desta espécie formam extensos tapetes de coloração verde-claro em locais de solo argiloso.

\section{Hyophila Brid.}

Gametófitos acrocárpicos, medianos, formando tufos. Caulídios primários eretos, poucos rizóides, ramos secundários ausentes ou raros. Filídios ligulados, planos, espiralados, involutos. Costa única, subpercurrente, estreita, secção transversal com camada de estereídios distinta, ápice do filídio obtuso, apiculado, margem do filídio involuta, margem inteira, não bordeada, células da lâmina quadráticoirregulares, isodiamétricas, lisas ou mamilosas, parede celular espessada ou delgada, reta, células da base do filídio mais claras, alongadas porém não infladas. Reprodução vegetativa por gemas. Seta longa, reta, torcida ou lisa. Cápsula exserta ereta, simétrica, subcilíndrica, rômbica, superfície lisa quando seca. Opérculo rostrado. Peristômio ausente. Caliptra glabra.

2.1. Hyophila involuta (Hook.) A. Jaeger, Ber. Thätigk. St. Gallischen Naturwiss. Ges. 1871-1872: 354. 1873.

Fig. 26 T-A1

Gametófitos pequenos, verde-escuros a marrom-enegrecidos. Filídios fortemente contorcidos, ovalado-lanceolados, ápice obtuso ou subagudo, mucronado, margem involuta quando seca, eretopatente, plana quando úmida, inteira e próximo ao ápice dentada; costa forte, excurrente em um mucro; células superiores arredondado-hexagonais, salientes; as basais quadráticas a retangulares, pelúcidas.

Material examinado: Minas Gerais, Conceição do Mato Dentro, Pirani et al. 5571 (SP389350; SPF); Santana do Riacho, Pirani et al. 3694 (SP372510).

Ocorre nos estados de AM, BA, CE, DF, ES, GO, PA, PB, PE, PI, PR, MA, MG, MS, MT, RJ, RO, RS e SP. Na Serra do Cipó, cresce em rocha. Esta espécie é extremamente característica pois apresenta coloração amarronzada típica e os filídios fortemente involutos quando secos. 
Flora da Serra do Cipó, Minas Gerais: Briófitas (Anthocerotophyta, Bryophyta e Marchantiophyta)

\section{Tortella (Lindb.) Limpr.}

Gametófitos acrocárpicos, medianos a robustos, formando tufos. Caulídios primários eretos, poucos rizóides, ramos secundários ausentes ou raros. Filídios lanceolados, planos, espiralados, quando secos crispados. Costa única, curtoexcurrente, estreita, secção transversal com camada de estereídios distinta, ápice do filídio agudo, margem do filídio revoluta, margem inteira, não bordeada, células da lâmina quadrático-irregulares, isodiamétricas, papilosas, parede celular espessada ou delgada, reta, células da base do filídio mais claras, alongadas porém não infladas, nitidamente formando uma região em forma de V. Seta longa, reta, lisa. Cápsula exserta ereta, simétrica, urna sub-cilíndrica, rômbica, superfície lisa quando seca. Opérculo rostrado. Peristômio simples. Caliptra glabra.

3.1. Tortella humilis (Hedw.) Jenn., Mann. Moss. W. Pennsylv. 96: 13. 1913.

Fig. 27 A-F

Gametófitos verde-oliva. Filídios curvos, oblongo-Inceolados a lingulados; ápice largo, curtamente apiculado, reflexos; margem inteira, células hialinas atingindo até a metade do filídio; costa forte, excurrente; células laminares superiores arredondadas, papilosas, papilas simples ou bifurcadas em ambas as superfícies; as basais retangulares, mamilosas.

Material examinado: Minas Gerais, Santana do Riacho, O. Yano \& Wanderley 10617, 10706, 10707, 10790, 10792, 10916 (SP220312; SP220401; SP220402; SP220483; SP220485; SP220609).

Ocorre nos estados de BA, DF, ES, GO, PR, MA, MG, MS, SC, RJ, RS e SP. Na Serra do Cipó, cresce em solo. Os gametófitos desta espécie são sempre encontrados com esporófitos, é facilmente identificada pela base do filídio que apresenta células sem papilas e formam uma faixa hialina que atinge até quase a metade do filídio.

\section{Weissia Hedw.}

Gametófitos acrocárpicos, medianos, formando tufos. Caulídios primários prostrados, poucos rizóides, ramos secundários ausentes ou raros. Filídios lanceolados, planos, espiralados, quando secos crispados. Costa única, curto-excurrente, estreita, secção transversal com camada de estereídios distinta, ápice do filídio agudo, margem do filídio revoluta, margem inteira, não bordeada, células da lâmina quadrático-irregulares, isodiamétricas, lisas ou mamilosas, parede celular espessada, reta, células da base do filídio mais claras, alongadas porém não infladas. Cápsula ereta, simétrica, urna sub-cilíndrica, rômbica, superfície lisa quando seca. Opérculo rostrado. Peristômio simples. Caliptra glabra.
4.1. Weissia controversa Hedw., Spec. Musc. Frond.: 67. 1801.

Fig. $27 \mathrm{G}-\mathrm{L}$

Gametófitos medianos, formando tufos. Caulídios primários prostrados. Filídios lanceolados, planos, espiralados, quando secos crispados. Costa única, curto-excurrente, estreita, secção transversal com camada de estereídios distinta, ápice do filídio agudo, margem do filídio revoluta, margem inteira, não bordeada, células da lâmina quadrático-irregulares, mamilosas, parede celular espessada, reta, células da base do filídio mais claras, alongadas porém não infladas. Cápsula ereta, simétrica, urna sub-cilíndrica, rômbica, superfície lisa quando seca. Opérculo rostrado. Peristômio simples. Caliptra glabra.

Material examinado: Minas Gerais, Santana do Riacho, Serra da Bandeirinha, O. Yano \& Wanderley 10748, 10928 (SP220442; SP220621).

Ocorre nos estados de AM, BA, DF, ES, GO, MG, PR, RJ, RS, SC e TO. Na Serra do Cipó, cresce em tronco vivo e solo.

\section{Pterobryaceae}

Gametófitos pleurocárpicos, medianos ou robustos, formando tufos. Caulídios primários prostrados, tomentosos, ramos secundários dendróides ou pendentes, pseudoparáfilos folhosos, lisos. Filídios lanceolados ou ovados, diferenciados entre ramos primários e secundários, simétricos, côncavos, espiralados ou em fileiras distintas, quando secos imbricados, base auriculada, ápice apiculado, pilífero ou agudo, margem plana, inteiras ou denticulada, não bordeada. Costa única, curta e dupla ou ausente, até $1 / 2$ ou $3 / 4$ compr. do filídio ou percurrente. Células da lâmina longo-hexagonais ou lineares, lisas ou papilosas, parede celular espessada, porosa ou reta, região alar 1-10 fileira de células infladas e coloridas de marrom a laranja. Dióicos, monóicos ou autóicos. Seta presente curta ou longa, reta, marrom-dourada, rugosa ou lisa. Cápsula exserta ou imersa, ereta, assimétrica, urna ovóide ou subcilíndrica, rômbica. Peristômio único. Caliptra glabra, não plicada.

É uma família amplamente distribuída no Brasil, caracterizada principalmente pelo hábito prostrado dos caulídios primários e ascendente a dendróide dos secundários. Ocorre principalmente como corticícola em áreas preservadas. Para a identificação das espécies é necessário análise da morfologia filídio dos filídios do caulídio e ramos. No Brasil ocorrem 11 gêneros e 26 espécies; na Serra do Cipó ocorrem três gêneros e três espécies.

Bibliografia básica - Gradstein et al. (2001); Sharp et al. (1994); Yano \& Peralta (2009). 


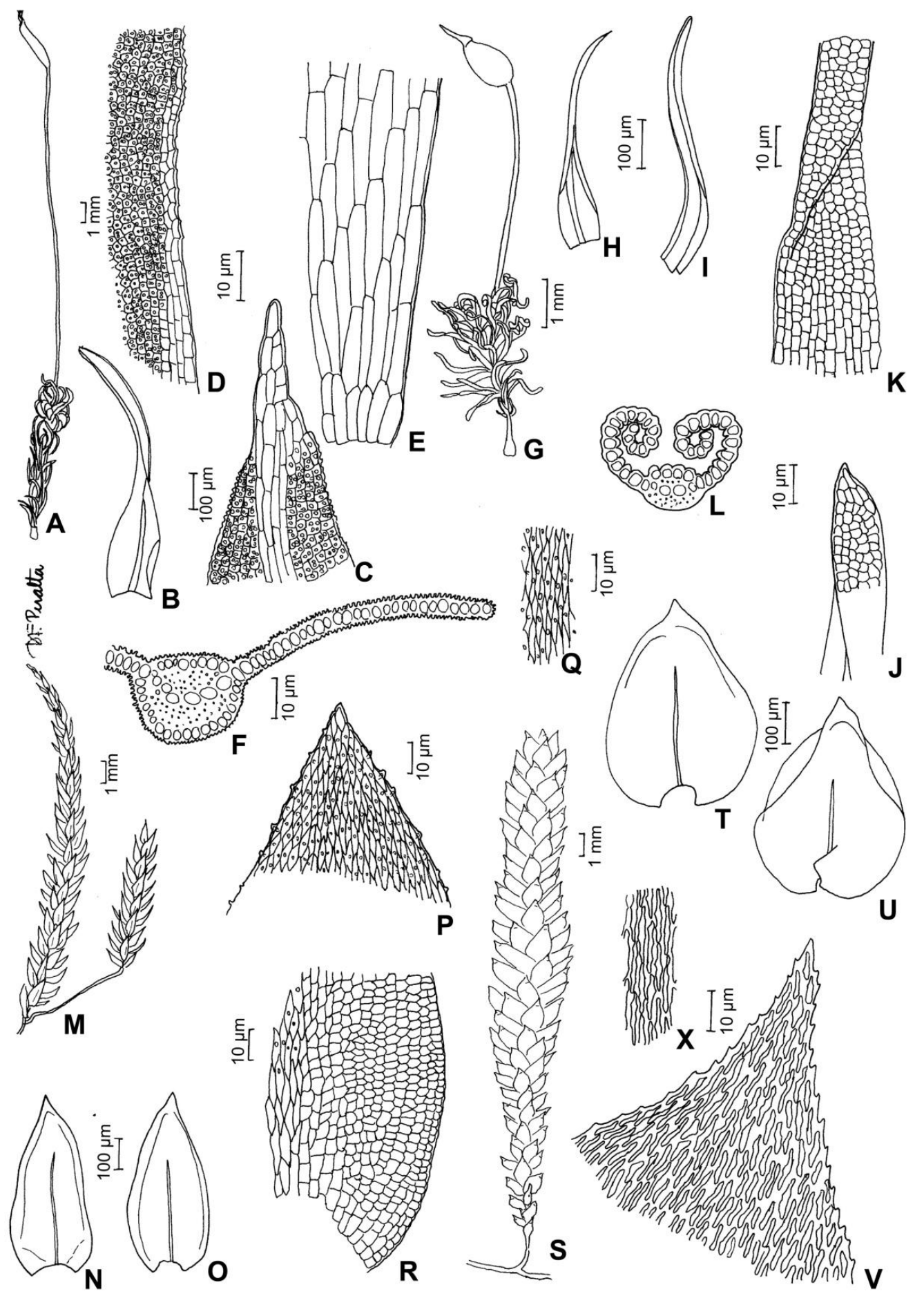

Fig. 27. Tortella humilis (Hedw.) Jenn. A. aspecto do gametófito. B. filídio. C. células do ápice do filídio. D células da margem do filídio. E. células da base do filídio. F. secção transversal do filídio. Weissia controversa Hedw. G. aspecto do gametófito. H-I. filídios. J. ápice do filídio. K. células da margem do filídio. L. secção transversal do filídio. Henicodium geniculatum (Mitt.) W.R. Buck. M. aspecto do gametófito. N-O. filídios. P. células do ápice do filídio. Q. células da lâmina do filídio. R. células da base do filídio. Jaegerina scariosa (Lor.) Arzeni. S. aspecto do gametófito. T-U. filídios. V. células do ápice do filídio. X. células da lâmina do filídio (A-F. O. Yano \& Wanderley 10617; G-L. O. Yano \& Wanderley 10748; M-R. Vital 7623 p.p.; S-X. O. Yano \& Wanderley 10668). 
Flora da Serra do Cipó, Minas Gerais: Briófitas (Anthocerotophyta, Bryophyta e Marchantiophyta)

Chave para os gêneros

1. Caulídios secundários pendentes, com muitas ramificações dendróides

3. Orthostichopsis

1'. Caulídios secundários ascendentes, não ramificados.

2. Filídios lanceolados, células unipapilosas, região alar diferenciada

2'. Filídios ovados, células lisas, região alar não diferenciada

1. Henicodium

2. Jaegerina

\section{Henicodium (Müll. Hal.) Kindb.}

Gametófitos pleurocárpicos, medianos, formando tufos. Caulídios primários prostrados, tomentosos, ramos secundários eretos, pseudoparáfilos, folhosas, lisas. Filídios lanceolados, côncavos, espiralados ou em fileiras distintas (3-5 fileiras), quando secos imbricados, base do filídio auriculada. Costa única, 1/2 ou 3/4 compr. do filídio, estreita, ápice do filídio apiculado ou pilífero ou agudo, margem do filídio plana, inteira, não bordeada, células da lâmina longo-hexagonais, papilosas, parede celular espessada, reta, células da base do filídio 1-10 fileira de células quadráticas. Seta curta, reta. Cápsula ereta, assimétrica, urna sub-cilíndrica, rômbica, superfície lisa quando seca. Opérculo rostrado. Peristômio simples. Caliptra glabra .

1.1. Henicodium geniculatum (Mitt.) W.R. Buck, Bryologist 92(4): 534. 1989.

Fig. $27 \mathrm{M}-\mathrm{R}$

Filídios lanceolados, ereto-adpressos, ápice acuminado, células do ápice e lâmina longohexagonais, unipapilosas, base pregueada nas laterais, região alar diferenciada, células quadráticoirregulares, sem papilas, costa simples ocupando $3 / 4$ da lâmina.

Material examinado: Minas Gerais, Itambé do Mato Dentro, Vital 7623 p.p., 7629 (SP136578; SP136579).

Associada a Frullania brasiliensis Raddi. Ocorre nos estados de AC, AL, AM, AP, BA, CE, DF, ES, GO, MT, PA, PB, PE, RJ, RO e SP. Na Serra do Cipó, cresce em tronco. Esta espécie é caracterizada pelo hábito sem ramificações dos ramos e as células da lâmina do filídio unipapilosas.

\section{Jaegerina Müll. Hal.}

Gametófitos pleurocárpicos, medianos, formando tufos. Caulídios primários prostrados, tomentosos, ramos secundários eretos, pseudoparáfilos, folhosas, lisas. Filídios ovados, côncavos, espiralados, quando secos espalhados. Costa única, $1 / 2$ ou $3 / 4$ compr. do filídio, estreita, ápice do filídio apiculado, margem do filídio plana, inteira ou denticulada, não bordeada, células da lâmina longohexagonais ou lineares, lisas, parede celular espessada, reta, células da base do filídio 1-10 fileira de células quadráticas. Seta longa, reta. Cápsula ereta, assimétrica, urna sub-cilíndrica, rômbica, superfície lisa quando seca. Opérculo rostrado. Peristômio simples. Caliptra glabra.

2.1. Jaegerina scariosa (Lor.) Arzeni, Amer. Midland. Natural. 52: 12. 1954.

Fig. $27 \mathrm{~S}-\mathrm{X}$

Gametófitos verde-claros, brilhantes. Filídios esquarrosos, ovalados; margem inteira a ligeiramente serrulada acima; costa simples até $1 / 2$ da lâmina; ápice acuminado; células superiores fusiformes a linear sinuosas; basais oblongas, pontuadas.

Material examinado: Minas Gerais, Santana do Riacho, O. Yano \& Wanderley 10668, 10821 (SP220363; SP220514).

Ocorre nos estados de AC, AL, AM, CE, DF, ES, GO, MG, MS, MT, PA, PE, RJ, RO, RR, SC, SP e TO. Na Serra do Cipó, cresce em tronco vivo. Os ramos simples e filídios oblongos são característicos desta espécie.

\section{Orthostichopsis Broth.}

Gametófitos pleurocárpicos, robustos, formando tufos. Caulídios primários prostrados, tomentosos, ramos secundários dendróides ou pendentes, pseudoparáfilos folhosos, lisos. Filídios lanceolado ou ovados. Filídios maiores nos ramos primários, côncavos, espiralados ou em fileiras distintas (3-5 fileiras), quando secos imbricados, base do filídio auriculada. Costa única, 1/2 ou 3/4 compr. do filídio, estreita, ápice do filídio pilífero, margem do filídio plana, inteira ou denticulada, não bordeada, células da lâmina longo-hexagonais, lisas, parede celular espessada, reta, células da base do filídio 1-10 fileira de células, infladas, marrons a laranja. Seta curta, reta. Cápsula ereta, assimétrica, urna subcilíndrica, rômbica, superfície lisa quando seca. Opérculo rostrado. Peristômio simples. Caliptra glabra.

3.1. Orthostichopsis tetragona (Sw. ex Hedw.) Broth. in Engler \& Prantl, Natürl. Pflanzenfam. 1(3): 805. 1906 .

Fig. $28 \mathrm{~A}-\mathrm{F}$

Gametófitos, robustos, formando tufos. Caulídios primários prostrados, secundários dendróides ou pendentes. Filídios lanceolados. Filídios maiores nos ramos primários, côncavos, em fileiras 


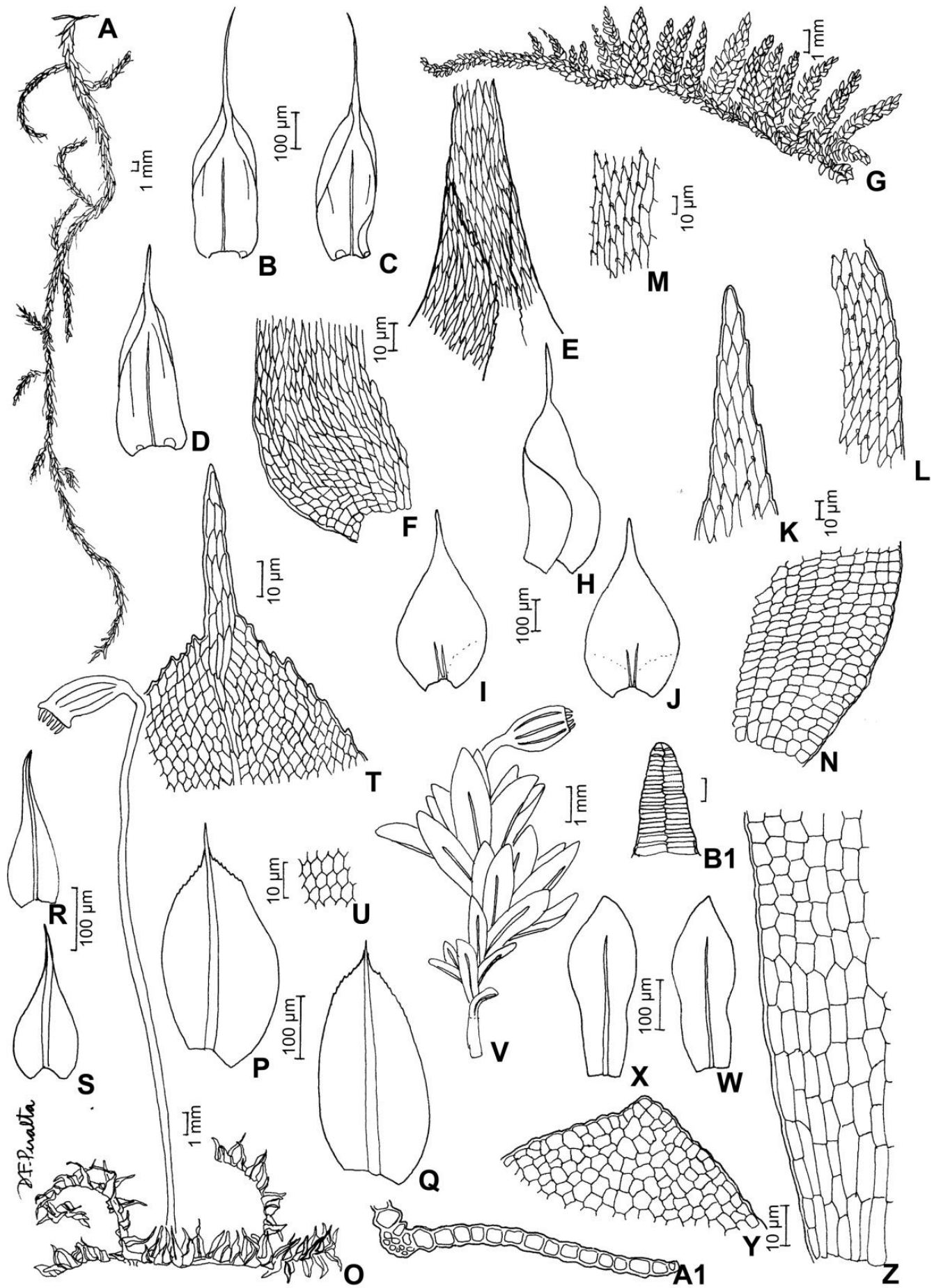

Fig. 28. Orthostichopsis tetragona (Sw. ex Hedw.) Broth. A. aspecto do gametófito. B-D. filídios. E. ápice do filídio. F. células da base do filídio. Trachyphyllum dusenii (Müll. Hal. ex Broth.) Broth. G. aspecto do gametófito. H. filídio do caulídio. I-J. filídios dos ramos. K. células do ápice do filídio. L. células da margem do filídio. M. células da lâmina do filídio. N. células da base do filídio. Racopilum tomentosum (Hedw.) Brid. O. aspecto do gametófito. P-Q. filídios laterais. R-S. filídios dorsais. T. células do ápice do filí́io. U. células da lâmina do filídio. Rhachithecium perpusillum (Thwait. \& Mitt.) Broth. V. aspecto do gametófito. X-W. filídios. Y. células do ápice do filídio. Z. células da base do filídio. A1. secção transversal do filídio. B1. dentes do peristômio (AF. Dias Neto 268; G-N. Câmara 1875 p.p.; O-U. O. Yano \& Wanderley 10799; V-B1. O. Yano \& Wanderley 10739). 
distintas (3-5 fileiras), quando secos imbricados, base do filídio auriculada. Costa única, $3 / 4$ compr. do filídio, estreita, ápice do filídio pilífero, margem do filídio plana, inteira, células da lâmina longo-hexagonais, lisas, parede celular espessada, reta, células da base do filídio 1-10 fileira de células, infladas, marrons a laranja. Seta curta, reta. Cápsula ereta, assimétrica, urna sub-cilíndrica, rômbica, superfície lisa quando seca. Opérculo rostrado. Peristômio simples. Caliptra glabra.

Material examinado: Minas Gerais, Santana do Riacho, Dias Neto 268 (SP419845).

Ocorre nos estados de AP, BA, CE, MG, PA, $P E, R S$ e SE. Existem duas espécies que apresentam a cápsula imersa e o ápice do filídio longo cuspidado a pilífero, $O$. tetragona e $O$. latifolia Sehnem, a diferenciação ocorre no número de células na região alar que em $O$. tetragona é de 20-30 e em O. latifolia é de 4-8.

\section{Pterygynandraceae}

É uma família amplamente distribuída na região do cerrado brasileiro, caracterizada principalmente pela costa simples, os filídios imbricados e células da lâmina prorulosas. Ocorre principalmente como corticícola. No Brasil ocorre apenas uma espécie.

Bibliografia básica - Gradstein et al. (2001); Sharp et al. (1994).

\section{Trachyphyllum A. Gepp}

Gametófitos pleurocárpicos, medianos, formando tapetes. Caulídios primários prostrados, poucos rizóides, ramos secundários ascendentes. Filídios lanceolados, côncavos, espiralados, quando secos imbricados. Costa dupla, curta, ca. 1/10 a 1/20 do compr., estreita, ápice do filídio acuminado, margem do filídio plana, denticulada, não bordeada, células da lâmina fusiformes, pouco alongadas, prorulosas, papilas, projetando-se dos ângulos distais, parede celular delgada, reta, células da base do filídio quadrático-irregulares. Seta longa, reta, lisa. Cápsula exserta, inclinada, assimétrica, urna ovóide, rômbica, superfície lisa quando seca. Opérculo rostrado, peristômio duplo. Caliptra glabra.

1.1. Trachyphyllum dusenii (Müll. Hal. ex Broth.) Broth. in Engler \& Prantl, Natürl. Pflanzenfam. 1(3): 890. 1907.

Fig. 28 G-N

Gametófitos medianos. Caulídios primários prostrados, secundários ascendentes. Filídios lanceolados, côncavos, quando secos imbricados. Costa dupla, curta, ca. 1/10 a 1/20 do compr., estreita, ápice do filídio acuminado, margens denticuladas, células da lâmina fusiformes, pouco alongadas, prorulosas, papilas, projetando-se dos ângulos distais, parede celular delgada, reta, células da base do filídio quadrático-irregulares. Seta longa, reta, lisa. Cápsula exserta, inclinada, assimétrica, urna ovóide, rômbica, superfície lisa quando seca. Opérculo rostrado, peristômio duplo. Caliptra glabra.

Material examinado: Minas Gerais, Santana do Riacho, Câmara 1875 p.p. (SP419633).

Associada a Rosulabryum billardierei (Schwägr.) J.R. Spence. Ocorre nos estados de DF, GO, MG e MT. Na Serra do Cipó ocorre em tronco de árvore. Os filídios imbricados assemelham-se ao aspecto das espécies do gênero Erythrodontium porém os gametófitos são muito menores. Raramente esta espécie é encontrada com esporófitos.

\section{Racopilaceae}

É uma família amplamente distribuída no Brasil, caracterizada principalmente pelo disposição em três fileiras dos filídios, com a fileira dorsal apresentando o formato muito diferente dos laterais. Ocorre principalmente como terrestre, corticícola, rupícola e saxícola. No Brasil ocorre apenas uma espécie.

Bibliografia básica - Gradstein et al. (2001); Sharp et al. (1994); Yano (1984b); Yano \& Costa (2000); Yano \& Peralta (2009).

\section{Racopilum P. Beauv.}

Gametófitos pleurocárpicos, medianos, formando tapetes. Caulídios primários prostrados, tomentosos, ramos secundários prostrados. Filídios lanceolados, diferenciados em laterais e dorsal, marcadamente assimétricos, planos, aplainados, quando secos crispados. Costa única, excurrente, estreita, ápice do filídio pilífero, margem do filídio plana, denteada, não bordeada, células da lâmina fusiformes ou quadrático-irregulares, isodiamétricas, lisas, parede celular delgada, reta, células da base do filídio iguais as da lâmina. Seta longa, curvada. Cápsula exserta, inclinada, assimétrica, urna piriforme, rômbica, superfície quando seca estriada. Opérculo rostrado, peristômio duplo. Caliptra glabra.

1.1. Racopilum tomenosum (Hedw.) Brid., Bryol. Univ. 2: 719.1827.

Fig. $28 \mathrm{O}-\mathrm{U}$

Gametófitos medianos, formando tapetes. Caulídios primários prostrados, secundários prostrados. Filídios lanceolados, diferenciados em laterais e dorsal, planos, aplainados, quando secos crispados. Costa única, excurrente, estreita, ápice do filídio pilífero, margem do filídio plana, denteada, não bordeada, células da lâmina fusiformes, isodiamétricas, lisas, parede celular delgada, reta, células da base do filídio iguais as da lâmina. Seta 
longa, curvada. Cápsula exserta, inclinada, assimétrica, urna piriforme, rômbica, superfície quando seca estriada. Opérculo rostrado, peristômio duplo. Caliptra glabra.

Material examinado: Minas Gerais, Santana do Riacho, O. Yano \& Wanderley 10757, 10777, 10799, 10902 (SP220451; SP220470; SP220492; SP220595).

Ocorre nos estados de AC, AM, BA, CE, DF, ES, GO, MG, MS, MT, PA, PE, PR, RJ, RO, RS, SC e SP. Na Serra do Cipó, cresce em solo e tronco vivo. A presença da fileira de filídios dorsal é diagnóstico para a identificação desta espécie. Quanto secos os filídios são fortemente enrugados.

\section{Rhachitheciaceae}

Gametófitos acrocárpicos, pequenos e delicados, gregários ou formando tufos. Caulídios primários eretos, ramos secundários ausentes ou raros. Filídios ligulado ou ovados, planos, espiralados, quando secos crispados, base simples. Costa única, percurrente, ápice do filídio obtuso ou agudo, margem plana, inteira, não bordeada. Células da lâmina circulares ou quadrático irregulares, isodiamétricas, lisas, parede celular delgada, reta, região alar mais claras e alongadas porém não infladas. Monóicos ou autóicos. Seta curta ou longa, reta, marrom-dourada, lisa. Cápsula exserta ou imersa, ereta, simétrica, urna ovóide ou globosa, rômbica. Peristômio ausente ou único. Caliptra pequena, glabra, não plicada.

É uma família amplamente distribuída nas áreas de cerrado do Brasil, caracterizada principalmente pelo hábito pequeno e pelo peristômio ausente ou único. Ocorre principalmente como corticícola e terrestre. Para a identificação das espécies é necessário análise da morfologia das células da lâmina do filídio. No Brasil ocorrem seis gêneros e oito espécies; na Serra do Cipó ocorrem dois gêneros e duas espécies.

Bibliografia básica - Gradstein et al. (2001); Sharp et al. (1994); Yano (1985); Yano \& Costa (2000).

\section{Chave para os gêneros}

1. Hábito corticícola, cápsula com estrias longitudinais

\section{Rhachithecium Le Jolis}

Gametófitos acrocárpicos, pequenos, delicados, gregários. Caulídios primários eretos, poucos rizóides, ramos secundários ausentes ou raros. Filídios ligulados, planos, espiralados, quando secos crispados. Costa única, percurrente, estreita, ápice do filídio obtuso, margem do filídio plana, inteira, não bordeada, células da lâmina quadráticoirregulares, isodiamétricas, lisas, parede celular delgada, reta, células da base do filídio mais claras, alongadas porém não infladas. Seta longa, reta. Cápsula ereta, simétrica, urna ovóide, rômbica, superfície quando seca estriada, ânulo presente. Opérculo cônico ou rostrado. Peristômio simples. Caliptra glabra.

1.1. Rhachithecium perpusillum (Thwait. \& Mitt.) Broth. in Engler \& Prantl, Natürl. Pflanzenfam. 1(3): 1199. 1909

Fig. 28 X-B1

Gametófitos acrocárpicos, eretos. Filídios ligulado-lanceolados, ápice agudo, espiralados, margem inteira, não bordeada, células da lâmina isodiamétricas, quadrático-irregulares, parede delgada, lisas, infladas em secção transversal, região alar, simples, costa simples, 3/4 compr., com estereídios na porção dorsal. Cápsula com estrias longitudinais.

Material examinado: Minas Gerais, Santana do Riacho, O. Yano \& Wanderley 10739, 10754 (SP220433; SP220448).

Ocorre nos estados de DF, GO, MG, MS e SP. $\mathrm{Na}$ Serra do Cipó, cresce em tronco vivo. Esta espécie apresenta a cápsula caracteristicamente sulcada e os filídios periqueciais bem diferenciados dos demais.

\section{Zanderia Goffinet}

Gametófitos acrocárpicos, pequenos, delicados, formando tufos. Caulídios primários eretos, poucos rizóides, ramos secundários ausentes ou raros. Filídios ligulados, planos, espiralados, quando secos crispados. Costa única, percurrente, estreita, ápice do filídio obtuso, margem do filídio plana, inteira, não bordeada, células da lâmina circulares ou quadrático-irregulares, isodiamétricas, lisas, parede celular delgada, reta, células da base do filídio mais claras, alongadas porém não infladas. Seta longa, reta. Cápsula ereta, simétrica, urna ovóide, rômbica, superfície quando seca lisa, ânulo presente. Opérculo cônico ou rostrado. Peristômio simples. Caliptra glabra. 
Flora da Serra do Cipó, Minas Gerais: Briófitas (Anthocerotophyta, Bryophyta e Marchantiophyta)

2.1. Zanderia octoblepharis (Spruce ex A. Jaeger) Goffinet, Bryologist 100(4): 434. 1997.

Fig. $29 \mathrm{~A}-\mathrm{H}$

Gametófitos acrocárpicos, eretos. Filídios espatulados, ápice arredondado, espiralados, margem inteira, não bordeada, células da lâmina isodiamétricas, rômbicas, parede delgada, lisas, infladas em secção transversal, região alar simples, costa simples, subpercurrente, com estereídios na porção dorsal. Cápsula lisa.

Material examinado: Minas Gerais, Santana do Riacho, O. Yano \& Wanderley 10629 (SP220324).

Ocorre nos estados de AM, BA, GO, MG, PA e PI. Na Serra do Cipó, cresce em solo arenoso. Esta é uma espécie conhecida somente para o Brasil e facilmente identificada quando está com esporófito, o hábito assemelha-se as espécies da família Pottiaceae, porém a secção transversal do filídio não apresenta camada de estereídios.

\section{Rhacocarpaceae}

É uma família amplamente distribuída nas áreas de planalto do Brasil, caracterizada principalmente pela coloração laranja avermelhada, ausência de costa e células alares muito diferenciadas. Ocorre principalmente como rupícola. Para a identificação das espécies é necessário análise da morfologia do filídio. No Brasil ocorrem um gêneros e três espécies, uma delas encontrada na Serra do Cipó.

Bibliografia básica - Gradstein et al. (2001); Sharp et al. (1994).

\section{Rhacocarpus Lindb.}

Gametófitos pleurocárpicos, robustos, formando tapetes. Caulídios primários eretos, poucos rizóides, ramos secundários ascendentes, irregulares. Filídios lanceolados, côncavos, espiralados, quando secos imbricados, base do filídio auriculada. Costa ausente, ápice do filídio apiculado ou pilífero, margem do filídio plana, inteira, bordeada, células da lâmina longo-hexagonais ou lineares, lisas, parede celular espessada, porosa, células da base do filídio 1-10 fileira de células, muito infladas, marrons a laranja. Seta longa, reta, lisa. Cápsula ereta, assimétrica, urna ovóide, rômbica, superfície quando seca enrugada. Opérculo rostrado. Peristômio ausente. Caliptra glabra.

1.1. Rhacocarpus purpurascens (Müll. Hal.) Paris, Index Bryol. Suppl.: 292. 1900.

Fig. 29 1-O

Gametófitos robustos, formando tapetes. Caulídios primários eretos, secundários ascendentes, irregulares. Filídios lanceolados, côncavos, espiralados, quando secos imbricados, base do filídio auriculada. Costa ausente, ápice do filídio pilífero, margem do filídio plana, inteira, bordeada, células da lâmina lineares, lisas, parede celular espessada, porosa, células da base do filídio 1-10 fileira de células, muito infladas, marrons a laranja. Seta longa, reta, lisa. Cápsula ereta, assimétrica, urna ovóide, rômbica, superfície quando seca enrugada. Opérculo rostrado. Peristômio ausente. Caliptra glabra.

Material examinado: Minas Gerais, Santana do Riacho, O. Yano \& Wanderley 10642 (SP220337).

Ocorre nos estados de ES, MG, PR, RJ, RS e SC. Na Serra do Cipó, cresce em rocha. A espécie mais próxima que ocorre no Brasil é Rhacocarpus inermis (Müll. Hal.) Lindb., porém nesta o ápice do filídio não é pilífero como em $R$. purpurascens.

\section{Rhizogoniaceae}

É uma família amplamente distribuída na região de Floresta Atlântica no Brasil, caracterizada principalmente pelo hábito ereto, filídios denteados e esporófitos surgindo em pequenas ramificações próximo a base dos ramos principais. Ocorre principalmente como corticícola e rupícola. Para a identificação das espécies é necessário análise da morfologia das células da lâmina do filídio. No Brasil ocorrem três gêneros e três espécies; na Serra do Cipó ocorre o gênero Pyrrhobryum com uma espécie.

Bibliografia básica - Gradstein et al. (2001); Sharp et al. (1994); Yano (1986).

\section{Pyrrhobryum Mitt.}

Gametófitos cladocárpicos, robustos, formando tufos. Caulídios primários prostrados, tomentosos, ramos secundários eretos, não ramificados. Filídios lanceolados, planos, espiralados, planos quando secos. Costa única, percurrente, estreita, secção transversal com camada de estereídios distinta, ápice do filídio acuminado, margem do filídio plana, denteada, não bordeada, células da lâmina circulares ou quadrático-irregulares, isodiamétricas, lisas, parede celular espessada, reta, células da base do filídio iguais as da lâmina. Seta longa, reta. Cápsula ereta ou horizontal, assimétrica, urna ovóide, rômbica, superfície lisa quando seca. Opérculo rostrado. Peristômio duplo. Caliptra glabra.

1.1. Pyrrhobryum spiniforme (Hedw.) Mitt., J. Linn. Soc. Bot. 10: 174. 1868.

Fig. 29 P-U

Gametófitos cladocárpicos, robustos, formando tufos. Caulídios primários prostrados, tomentosos, ramos secundários eretos, não ramificados. Filídios lanceolados, planos, espiralados, planos quando secos. Costa única, percurrente, estreita, secção transversal com camada de estereídios distinta, ápice do filídio acuminado, margem do filídio plana, 


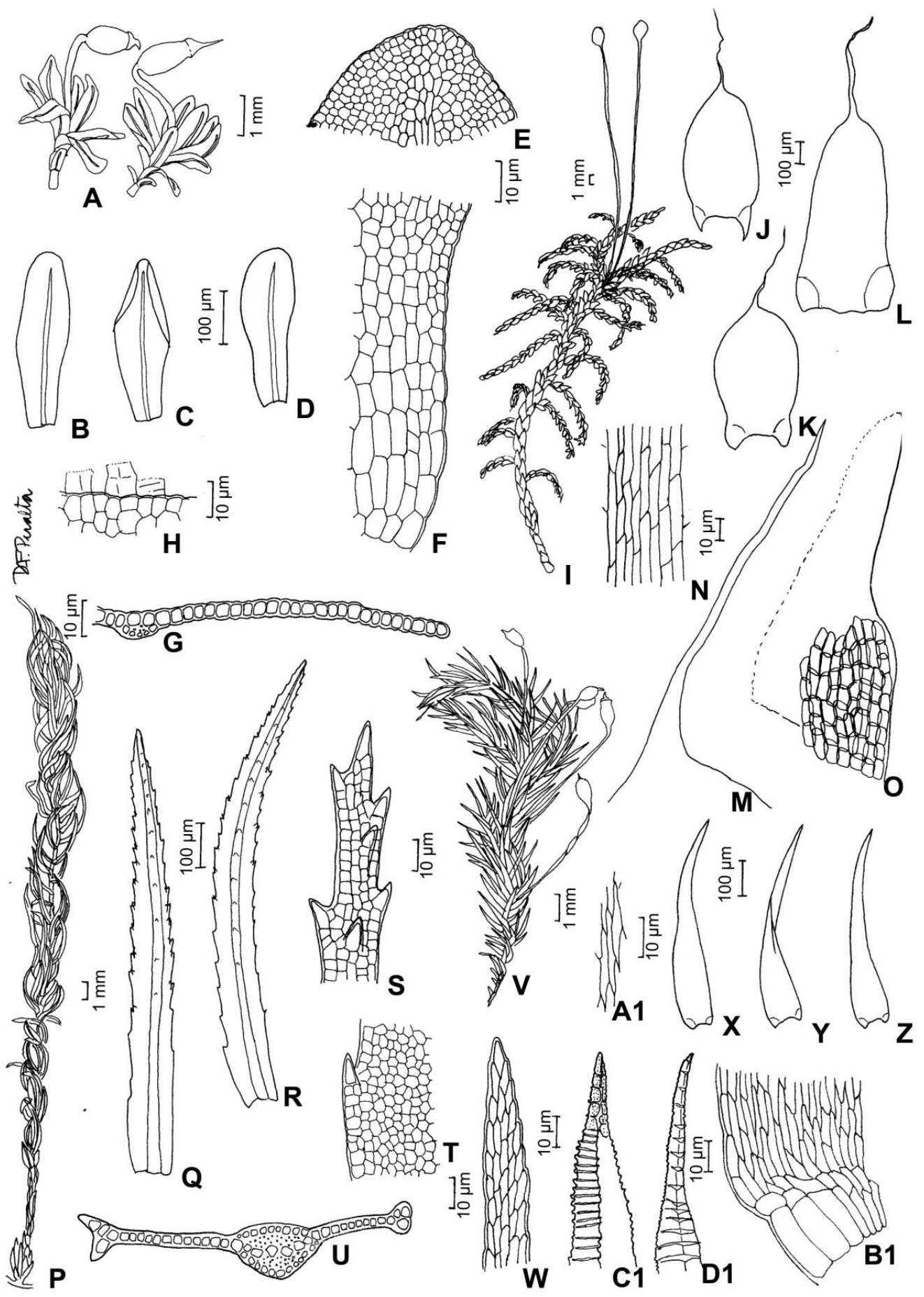

Fig. 29. Zanderia octoblepharis (Spruce ex A. Jaeger) Goffinet. A. aspecto do gametófito. B-D. filídios. E. células do ápice do filídio. F. células da base do filídio. G. secção transversal do filídio. H. dentes do peristômio. Rhacocarpus purpurascens (Müll. Hal.) Paris. I. aspecto do gametófito. J-L. filídios. M. ápice do filídio. N. células da lâmina do filídio. O. células da base do filídio. Pyrrhobryum spiniforme (Hedw.) Mitt. P. aspecto do gametófito. Q-R. filídios. S. células do ápice do filídio. T. células da margem do filídio. U. secção transversal do filídio. Acroporium estrellae (Müll. Hal.) W.R. Buck \& Schäfer-Verw. V. aspecto do gametófito. X-Z. filídios. W. células do ápice do filídio. A1. células da lâmina do filídio. B1. células da base do filídio. C1. dentes do exóstomo. D1. endóstomo (A-H. O. Yano \& Wanderley 10629; I-O. O. Yano \& Wanderley 10642; P-U. O. Yano \& Wanderley 10830; V-D1. O. Yano 502). 
Flora da Serra do Cipó, Minas Gerais: Briófitas (Anthocerotophyta, Bryophyta e Marchantiophyta)

denteada, não bordeada, células da lâmina circulares ou quadrático-irregulares, isodiamétricas, lisas, parede celular espessada, reta, células da base do filídio iguais as da lâmina. Seta longa, reta. Cápsula ereta ou horizontal, assimétrica, urna ovóide, rômbica, superfície lisa quando seca. Opérculo rostrado. Peristômio duplo. Caliptra glabra.

Material examinado: Minas Gerais, Santana do Riacho, Prado s.n. (SP220625); O. Yano \& Wanderley 10830 (SP220523).

Ocorre nos estados de AM, BA, ES, MG, MT, PE, PR, RJ, RO, RR, RS, SC e SP. Na Serra do Cipó, cresce em tronco caído. Esta espécie é facilmente identificada, os gametófitos são grandes e apresentam a margem duplo-denteadas e costa denteada dorsalmente.

\section{Sematophyllaceae}

Gametófitos pleurocárpicos, medianos, formando tapetes. Caulídios primários prostrados, ramos secundários ascendentes ou pendentes, sem paráfilos ou pseudoparáfilos. Filídios lanceolados, côncavos ou secundos, espiralados, base simples ou auriculada, ápice obtuso, acuminado ou agudo, margem plana, inteiras, não bordeado. Costa ausente. Células da lâmina fusiformes ou longo-hexagonais, lisas ou papilosas, parede celular espessada ou delgada, porosa ou reta, região alar 1-10 fileira de células infladas e coloridas de marrom a laranja. Dióicos, monóicos ou autóicos. Seta longa, reta ou curvada, marrom-dourada ou avermelhada, lisa. Cápsula exserta, ereta ou inclinada, assimétrica, urna ovóide ou subcilíndrica, rômbica. Peristômio único ou duplo. Caliptra glabra, não plicada.

É uma família amplamente distribuída no Brasil, caracterizada principalmente pelo hábito prostrado dos caulídios primários e ascendente dos secundários, ausência de costa e as células alares freqüentemente infladas. Ocorre principalmente em diversos substratos. Para a identificação das espécies é necessário análise da morfologia das células da lâmina do filídio e dos dentes do peristômio. No Brasil ocorrem 19 gêneros e 90 espécies; na Serra do Cipó ocorrem seis gêneros e 14 espécies.

Bibliografia básica - Gradstein et al. (2001); Sharp et al. (1994); Yano \& Peralta (2009).

\section{Chave para os gêneros}

1. Ápice do filídio agudo

5. Sematophyllum p.p.

1'. Ápice do filídio acuminado a cuspidado.

2. Ápice do filídio acuminado.

3. Hábito prostrado, filídios falcados

3'. Hábito ascendente, filídios incurvado ou não quando seco.

4. Caulídios quando secos ereto-ascendentes.

5. Células da lâmina 5-10:1; células supra-alares infladas; filídios planos; margem na porção mediana superior plana 1. Acroporium

5'. Células da lâmina lineares; células supra-alares não infladas; filídios côncavos; margem na porção mediana superior recurvada 4. Pylaisiadelpha

4'. Caulídios quando secos incurvados.

6. Filídios côncavos; células supra-alares infladas; gametófitos medianos; peristômio duplo facilmente visualizado 5. Sematophyllum p.p.

6'. Filídios planos; células supra-alares não infladas; gametófitos pequenos; peristômio com endóstomo reduzido

2'. Ápice do filídio cuspidado.

7. Células da lâmina 2-4:1

7'. Células da lâmina 5-10:1 a lineares.

8. Células da lâmina 5-10:1.

9. Filídios côncavos; margem na porção mediana superior recurvada; gametófitos medianos

5. Sematophyllum p.p.

9'. Filídios planos; margem na porção mediana superior plana; gametófitos pequenos.

10. Caulídios avermelhados; células do exotécio colenquimatosas; ramos ascendentes igualmente foliados; propagação vegetativa não conhecida

10'. Caulídios amarronzados; células do exotécio não colenquimatosas; ramos ascendentes com os filídios diminuindo gradualmente de tamanho em direção ao ápice; propagação vegetativa por ramos caducos

2. Donnellia

5. Sematophyllum p.p. da lâmina lineares.

11. Caulídios avermelhados; células alares diferenciadas (infladas e coloridas); células do exotécio colenquimatosas

11'. Caulídios amarronzados; células alares pouco diferenciadas (quadráticas); células do exotécio não colenquimatosas

5. Sematophyllum p.p.

5. Sematophyllum p.p.

3. Pterogonidium 


\section{Acroporium Mitt.}

Gametófitos pleurocárpicos, medianos, formando tapetes. Caulídios primários prostrados, poucos rizóides, ramos secundários ascendentes ou pendentes. Filídios lanceolados, côncavos, espiralados, quando secos imbricados, base do filídio auriculada. Costa ausente, ápice do filídio acuminado, margem do filídio plana, inteira, não bordeada, células da lâmina longo-hexagonais, lisas, parede celular espessada, porosa ou reta, células da base do filídio 1-10 fileira de células, muito infladas, marrons a laranja. Seta longa, reta, lisa. Cápsula ereta, assimétrica, urna ovóide, rômbica, ânulo presente. Opérculo rostrado. Peristômio duplo. Caliptra glabra.

1.1. Acroporium estrellae (Müll. Hal.) W.R. Buck \& Schäfer-Verw., Bolm. Mus. Paraense Emílio Goeldi, Bot. 7: 646. 1991 (1993).

Fig. $29 \mathrm{~V}$-D1

Gametófitos medianos, ramos ascendentes igualmente foliados, quando secos ascendentes, caulídios amarronzados. Filídios lanceolados, planos, margem na porção mediana superior plana, ápice acuminado, células 5-10:1, lisas, parede celular lisas, células alares diferenciadas (infladas e coloridas), células supra-alares infladas. Peristômio duplo, dentes do peristômio estriados abaixo, células do exotécio colenquimatosas, propagação vegetativa não conhecida.

Material examinado: Minas Gerais, Conceição do Mato Dentro, O. Yano 502 (SP135465); Santana do Riacho, Câmara 1935 (SP419655); Câmara et al. 2071 (SP419704); Dias Neto 160 (SP419781).

Ocorre nos estados de AL, BA, CE, DF, GO, MG, PA, PR, RJ, RS, SC e SP. Na Serra do Cipó, cresce em tronco vivo e caído. Esta espécie é a que possui os filídios mais estreitos das espécies desta família encontradas na área, e as células com as paredes espessadas regularmente são características.

\section{Donnellia Austin}

Gametófitos pleurocárpicos, medianos, formando tapetes. Caulídios primários prostrados, poucos rizóides, ramos secundários ascendentes. Filídios lanceolados, côncavos, espiralados, quando secos imbricados, base do filídio simples. Costa ausente, ápice do filídio agudo, margem do filídio plana, inteira, não bordeada, células da lâmina fusiformes, lisas, parede celular delgada, reta, células da base do filídio 1-10 fileira de células, muito infladas, marrons a laranja. Seta longa, reta, lisa. Cápsula ereta, assimétrica, urna sub-cilíndrica, rômbica, ânulo presente. Opérculo rostrado. Peristômio duplo, endóstomo reduzido. Caliptra glabra.

2.1. Donnellia commutata (Müll. Hal.) W.R. Buck, Bryologist 91(2): 134. 1988.

Fig. $30 \mathrm{~A}-\mathrm{H}$

Gametófitos pequenos, ramos ascendentes igualmente foliados, quando secos incurvados, caulídios amarronzados. Filídios lanceolados, planos, margem na porção mediana superior recurvada, ápice acuminado, células 2-4:1, lisas, parede celular lisas, células alares diferenciadas (infladas e coloridas), células supra-alares não infladas. Peristômio duplo, dentes do peristômio não estriados, células do exotécio colenquimatosas, endóstomo reduzido, propagação vegetativa não conhecida.

Material examinado: Minas Gerais, Conceição do Mato Dentro, O. Yano 499 (SP135463); Santana do Riacho, O. Yano \& Wanderley 10627, 10709 (SP220322; SP220404); Câmara 1844, 1845, 1853 (SP419621; SP419622; SP419625); Dias Neto 63, 65, 67, 69, 101 p.p., 273 (SP419721; SP419722; SP419723; SP419724; SP419739; SP419848)

Associada a Frullania gibbosa Nees. Ocorre nos estados de AM, BA, CE, DF, ES, GO, MG, MS, PA, RJ, RS e SP. Na Serra do Cipó, cresce em tronco vivo. Esta espécie é a que possui o esporófito mais curto de todas as espécies encontradas, a seta chega a se apenas uma vez e meia a duas vezes 0 comprimento da cápsula, e ainda, mesmo sob lupa é possível ver a coloração esbranquiçada dos dentes do peristômio.

\section{Pterogonidium Broth.}

Gametófitos pleurocárpicos, delicados, formando tapetes. Caulídios primários prostrados, poucos rizóides, ramos secundários ascendentes. Filídios lanceolados, côncavos, espiralados, quando secos imbricados, base do filídio simples. Costa ausente, ápice do filídio acuminado, margem do filídio plana, inteira, não bordeada, células da lâmina longohexagonais, lisas, parede celular delgada, reta, células da base do filídio 1-10 fileira de células, quadráticas. Seta longa, reta, lisa. Cápsula ereta, assimétrica, urna sub-cilíndrica, rômbica, ânulo presente. Opérculo rostrado. Peristômio duplo. Caliptra glabra. 


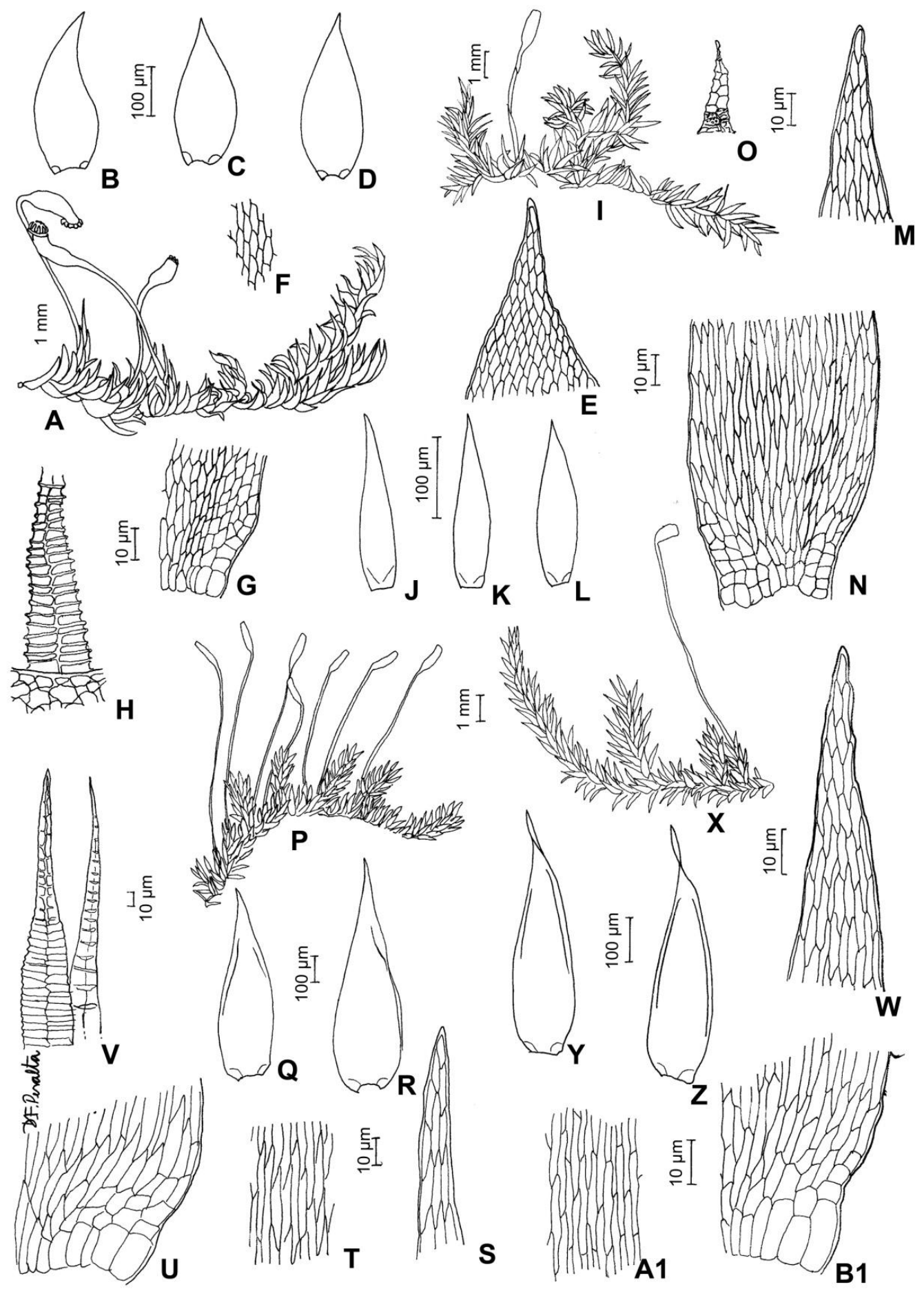

Fig. 30. Donnellia commutata (Müll. Hal.) W.R. Buck. A. aspecto do gametófito. B-D. filídios. E. células do ápice do filídio. F. células da lâmina do filídio. G. células da base do filídio. H. dente do exóstomo. Pterogonidium pulchellum (Hook.) Müll. Hal. ex Broth. I. aspecto do gametófito. J-L. filídios. M. células do ápice do filídio. N. células da base do filídio. O. dente do peristômio. Pylaisiadelpha brasiliensis H.A. Crum. P. aspecto do gametófito. Q-R. filídios. s. células do ápice do filídio. T. células da lâmina do filídio. U. células da base do filídio. V. dentes do peristômio. Sematophyllum adnatum (Michx.) E. Britton. X. aspecto do gametófito. Y-Z. filídios. W. células do ápice do filídio. A1. células da lâmina do filídio. B1. células da base do filídio (A-H. $O$. Yano 499; I-O. O. Yano \& Wanderley 10711; P-V. Dias Neto 126; X-B1. Vital 7619). 
3.1. Pterogonidium pulchellum (Hook.) Müll. Hal. ex Broth. in Engler \& Prantl, Natürl. Pflanzenfam. 1(3): 1100. 1908.

Fig. $30 \mathrm{I}-\mathrm{O}$

Gametófitos pequenos, ramos ascendentes igualmente foliados, quando secos prostrados, caulídios amarronzados. Filídios lanceolados, planos, margem na porção mediana superior plana, ápice cuspidado, células lineares, lisas, parede celular lisas, células alares pouco diferenciadas (quadráticas), células supra-alares não infladas. Peristômio duplo, dentes do peristômio estriados abaixo, células do exotécio não colenquimatosas, propagação vegetativa não conhecida.

Material examinado: Minas Gerais, Santana do Riacho, O. Yano \& Wanderley 10711 (SP220406); Pirani et al. 6271 p.p. (SP432412, SPF).

Ocorre nos estados de AM, AP, BA, CE, PA, PE, RJ, RO, RS e SP. Associada a Octoblepharum albidum Hedw. Na Serra do Cipó, cresce em tronco vivo. Esta é a espécie que apresenta o menor hábito, os gametófitos são delicados e contrastam com o grande esporófito. Esta espécie pode ser confundida com espécies de Isopterygium, mas ela não possui pseudoparáfilos e em $P$. pulchellum os dentes do peristômio são muito pequeno em relação a cápsula.

\section{Pylaisiadelpha Cardot}

Gametófitos pleurocárpicos, medianos, formando tapetes. Caulídios primários prostrados, poucos rizóides, ramos secundários ascendentes. Filídios lanceolados, côncavos, espiralados, quando secos imbricados, base do filídio auriculada. Costa ausente, ápice do filídio acuminado, margem do filídio plana, inteira, não bordeada, células da lâmina lineares, lisas, parede celular delgada, reta, células da base do filídio 1-10 fileira de células, muito infladas, marrons a laranja. Seta longa, reta ou curvada, lisa. Cápsula ereta ou inclinada, assimétrica, urna sub- cilíndrica, rômbica, ânulo presente. Opérculo rostrado. Peristômio duplo. Caliptra glabra.

4.1. Pylaisiadelpha brasiliensis H.A. Crum, Bryologist 87(3): 214. 1984.

Fig. $30 \mathrm{P}-\mathrm{V}$

Gametófitos medianos, ramos ascendentes igualmente foliados, quando secos ascendentes, caulídios amarronzados. Filídios lanceolados, côncavos, margem na porção mediana superior recurvada, ápice acuminado, células lineares, lisas, parede celular lisas, células alares diferenciadas (infladas e coloridas), células supra-alares não infladas. Peristômio duplo, dentes do peristômio estriados abaixo, células do exotécio não colenquimatosas, propagação vegetativa não conhecida.

Material examinado: Minas Gerais, Santana do Riacho, Dias Neto 126 (SP419759).

Ocorre no estado de SP. Na Serra do Cipó, cresce em tronco vivo. Esta é a segunda ocorrência desta espécie no Brasil, ela parece estar relacionada com áreas preservadas de Floresta Atlântica.

\section{Sematophyllum Mitt.}

Gametófitos pleurocárpicos, medianos, formando tapetes. Caulídios primários prostrados, poucos rizóides, ramos secundários ascendentes. Filídios lanceolados, côncavos ou secundos. Espiralados, quando secos imbricados, base do filídio simples ou auriculada. Costa ausente, ápice do filídio obtuso ou acuminado ou agudo, margem do filídio plana, inteira, não bordeada, células da lâmina fusiformes ou longo-hexagonais, lisas, parede celular delgada, reta, células da base do filídio 1-10 fileira de células, muito infladas, marrons a laranja. Seta longa, reta, lisa. Cápsula ereta, assimétrica, urna ovóide ou sub-cilíndrica, rômbica, ânulo presente. Opérculo rostrado. Peristômio duplo. Caliptra glabra.

1. Ápice do filídio obtuso

1'. Ápice do filídio agudo, acuminado ou cuspidado.

2. Ápice do filídio agudo.

3. Células da lâmina 5-10:1; células supra-alares infladas

5.2. S. campicola

3'. Células da lâmina lineares; células supra-alares não infladas

5.6. S. subdepressum

2'. Ápice do filídio acuminado a cuspidado

4. Ápice do filídio acuminado.

5. Hábito prostrado, filídios falcados 5.5. S. reitzii

5'. Hábito ascendente, filídios incurvado ou não quando seco

5.9. S. swartzii

4'. Ápice do filídio cuspidado.

6. Células da lâmina 2-4:1

6'. Células da lâmina 5-10:1 a lineares.

7. Células da lâmina lineares

7'. Células da lâmina 5-10:1.

8. Filídios côncavos; margem na porção mediana superior recurvada; gametófitos medianos

8'. Filídios planos; margem na porção mediana superior plana; gametófitos pequenos 
Flora da Serra do Cipó, Minas Gerais: Briófitas (Anthocerotophyta, Bryophyta e Marchantiophyta)

5.1. Sematophyllum adnatum (Michx.) E. Britton, Bryologist 5(4): 65. 1902.

Fig. $30 \mathrm{X}-\mathrm{B} 1$

Gametófitos pequenos, ramos ascendentes igualmente foliados, quando secos ascendentes, caulídios avermelhados. Filídios lanceolados, planos, margem na porção mediana superior plana, ápice cuspidado, células 5-10:1, lisas, parede celular lisas, células alares diferenciadas (infladas e coloridas), células supra-alares não infladas. Peristômio duplo, dentes do peristômio estriados abaixo, células do exotécio colenquimatosas, propagação vegetativa não conhecida.

Material examinado: Minas Gerais, Itambé do Mato Dentro, Vital 7619 (SP136574); Santana do Riacho, Pirani et al. 10290 (SP230722, SPF170934).

Ocorre nos estados do AM, BA, DF, ES, GO, MT, PA, PE, PI, RJ, RS, SC, SP e TO. Na Serra do Cipó, cresce em tronco vivo.

5.2. Sematophyllum campicola (Broth.) Broth. in Engler \& Prantl, Natürl. Pflanzenfam. ed 2, 11: 432. 1925.

Fig. 31 A-G

Gametófitos pequenos, ramos ascendentes igualmente foliados, quando secos incurvados, caulídios amarronzados. Filídios ligulados, côncavos, margem na porção mediana superior plana, ápice obtuso, células 2-4:1, lisas, parede celular lisas, células alares diferenciadas (infladas e coloridas), células supra-alares não infladas. Peristômio duplo, dentes do peristômio estriados abaixo, células do exotécio colenquimatosas, propagação vegetativa não conhecida.

Material examinado: Minas Gerais, Jaboticatubas, Hatschbach 30019 (SP201785); Dias Neto 62, 91, 104, 106, 128 (SP419720; SP419733; SP419741; SP419743; SP419761).

Ocorre nos estados de ES, MG, PR, RJ, RS e SP. Na Serra do Cipó, cresce em tronco vivo. Esta é uma espécie curiosa, o hábito assemelha-se a $S$. subpinnatum, porém o ápice oblongo a ligulado está mais semelhante a Colobodontium. Dessa maneira preferimos deixar o nome $S$. campicola e uma revisão futura trará maiores esclarecimentos, uma vez que este nome ainda não foi revisado taxonomicamente.
5.3. Sematophyllum cuspidiferum Mitt., J. Linn. Soc. Bot. 12: 480. 1869.

Fig. $31 \mathrm{H}-\mathrm{P}$

Gametófitos medianos, ramos ascendentes igualmente foliados, quando secos ascendentes, caulídios amarronzados. Filídios lanceolados, côncavos, margem na porção mediana superior recurvada, ápice cuspidado, células 5-10:1, lisas, parede celular lisas, células alares diferenciadas (infladas e coloridas), células supra-alares não infladas. Peristômio duplo, dentes do peristômio estriados abaixo, células do exotécio colenquimatosas, propagação vegetativa não conhecida.

Material examinado: Minas Gerais, Conceição do Mato Dentro, O. Yano 528 (SP135484); Vital 7581 p.p. (SP136551); Santana do Riacho, O. Yano \& Wanderley 10632, 10682, 10718, 10901 (SP220327; SP220377; SP220413; SP220594).

Associada a Neesioscyphus homophyllus (Nees) Grolle. Ocorre nos estados de CE, GO, MG, MS, MT e SP. Na Serra do Cipó, cresce em solo arenoso e tronco vivo.

5.4. Sematophyllum galipense (Müll. Hal.) Mitt., J. Linn. Soc. Bot. 12: 480. 1869.

Fig. $31 \mathrm{Q}-\mathrm{V}$

Gametófitos medianos, ramos ascendentes igualmente foliados, quando secos ascendentes, caulídios amarronzados. Filídios lanceolados, côncavos, margem na porção mediana superior recurvada, ápice cuspidado, células 2-4:1, lisas, parede celular lisas, células alares diferenciadas (infladas e coloridas), células supra-alares infladas. Peristômio duplo, dentes do peristômio estriados abaixo, células do exotécio colenquimatosas, propagação vegetativa não conhecida.

Material examinado: Minas Gerais, Conceição do Mato Dentro, Vital 1258 (SP88565); Santana do Riacho, O. Yano \& Wanderley 10680 p.p., 10737, 10755 (SP220375; SP220431; SP220449); Câmara 1889 (SP419638); Câmara et al. 2087 (SP419702); Dias Neto 173 (SP419790).

Associada a Callicostella pallida (Hornsch.) Ångstr. Ocorre nos estados de BA, CE, DF, ES, GO, PA, PE, RO, RR, MG, MT, PR, RJ, RS, SC, SP e TO. $\mathrm{Na}$ Serra do Cipó, cresce em solo e rocha. 


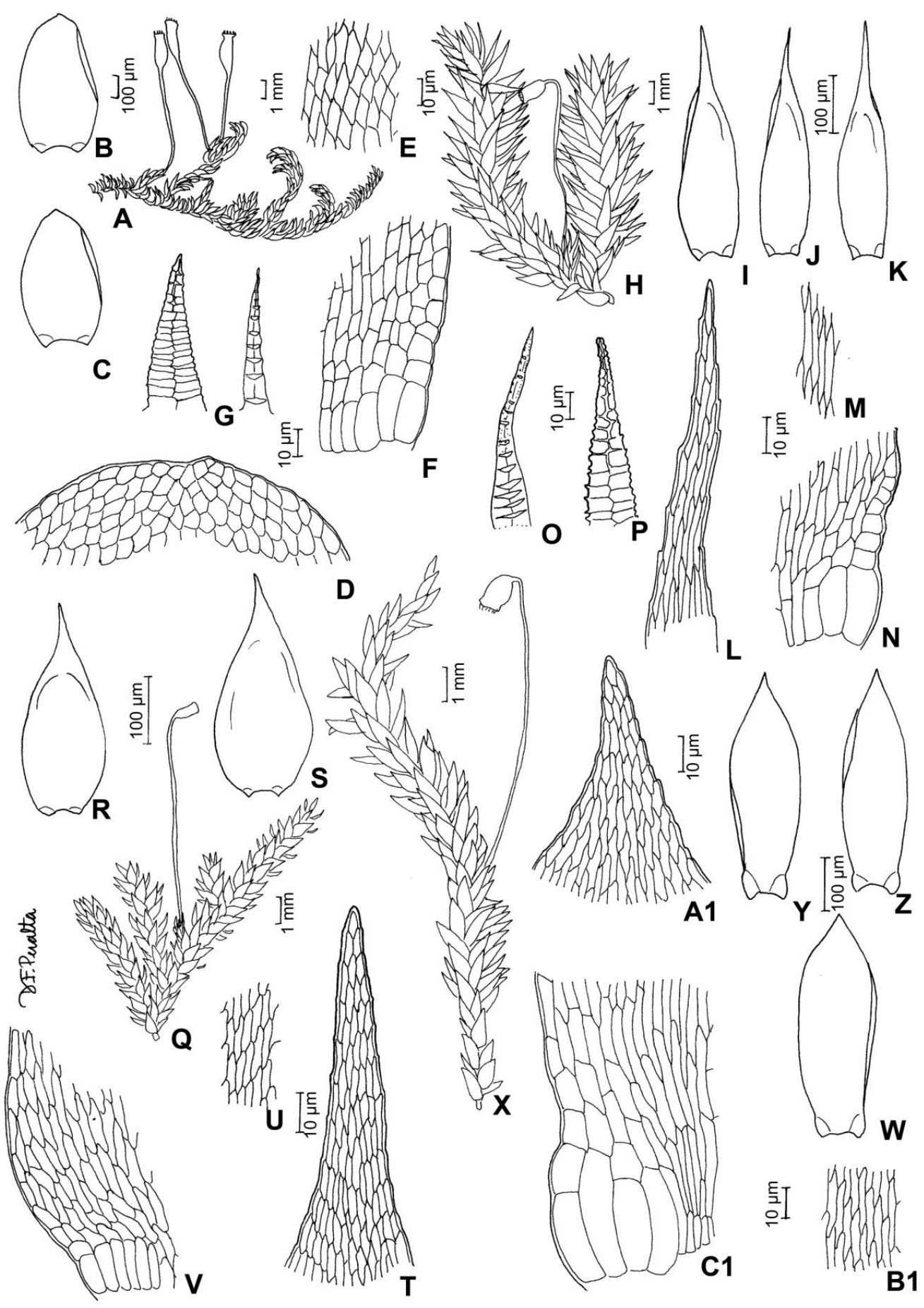

Fig. 31. Sematophyllum campicola (Broth.) Broth. A. aspecto do gametófito. B-C. filídios. D. células do ápice do filídio. E. células da lâmina do filídio. F. células da base do filídio. G. dentes do peristômio. Sematophyllum cuspidiferum Mitt. H. aspecto do gametófito. I-K. filídios. L. células do ápice do filídio. M. células da lâmina do filídio. N. células da base do filídio. O. dente do endóstomo. P. dente do exóstomo. Sematophyllum galipense (Müll. Hal.) Mitt. Q. aspecto do gametófito. R-S. filídios. T. células do ápice do filídio. U. células da lâmina do filídio. V. células da base do filídio. Sematophyllum reitzii E.B. Bartram. X. aspecto do gametófito. Y-W. filídios. A1. células do ápice do filídio. B1. células da lâmina do filídio. C1. células da base do filídio (A-G. Hatschbach 30019; H-P. O. Yano 528; Q-V. Vital 1258; X-C1. O. Yano \& Wanderley 10687). 
Flora da Serra do Cipó, Minas Gerais: Briófitas (Anthocerotophyta, Bryophyta e Marchantiophyta)

5.5. Sematophyllum reitzii E.B. Bartram, J. Washington Acad. Sci. 42(6): 182. 1952.

Fig. $31 \mathrm{X}-\mathrm{C} 1$

Gametófitos medianos, ramos ascendentes igualmente foliados, quando secos ascendentes, caulídios amarronzados. Filídios lanceolados ou oblongo-lanceolados, côncavos, margem na porção mediana superior plana, ápice agudo, células lineares, lisas, parede celular lisas, células alares diferenciadas (infladas e coloridas), células supra-alares não infladas. Peristômio duplo, dentes do peristômio estriados abaixo, células do exotécio colenquimatosas, propagação vegetativa não conhecida.

Material examinado: Minas Gerais, Conceição do Mato Dentro, O. Yano \& Wanderley 10687 (SP220382); Câmara et al. 2077 (SP419701).

Ocorre nos estados de PR, RS e SC. Na Serra do Cipó, cresce em rocha e tronco vivo. Esta espécie apresenta o hábito e as células alares dispostas em agrupamentos características do gênero Aptychopsis porém os dentes do peristômio das amostras analisadas não apresentavam estrias, e dessa maneira optamos por utilizar o nome $S$. retzii.

5.6. Sematophyllum subdepressum (Hampe) Broth. in Engler \& Prantl, Natürl. Pflanzenfam. ed 2, 11: 433. 1925.

Fig. $32 \mathrm{~A}-\mathrm{H}$

Gametófitos medianos, ramos ascendentes igualmente foliados, quando secos ascendentes, caulídios amarronzados. Filídios lanceolados ou oblongolanceolados, côncavos, margem na porção mediana superior plana, ápice agudo, células 5-10:1, lisas, parede celular lisas, células alares diferenciadas (infladas e coloridas), células supra-alares infladas. Peristômio duplo, dentes do peristômio estriados abaixo, células do exotécio colenquimatosas, propagação vegetativa não conhecida.

Material examinado: Minas Gerais, Conceição do Mato Dentro, Vital 1239 (SP88513); Congonhas do Norte, Pirani et al. 5641 p.p. (SP389358; SPF); Santana do Riacho, O. Yano \& Wanderley 10864 (SP220557); Dias Neto 142 (SP419773).

Associada a Isotachis multiceps (Lindenb. \& Gottsche) Gottsche. Ocorre nos estados de GO, MT, PR, RJ, RS, SC e SP. Na Serra do Cipó, cresce em rocha. Esta é uma espécie com hábito robusto e característica de rochas na margem de riachos.

5.7. Sematophyllum subpinnatum (Brid.) E. Britton, Bryologist 21(2): 28. 1918 (1919).

Fig. 32 I-N

Gametófitos medianos, ramos ascendentes igualmente foliados, quando secos incurvados, caulídios amarronzados. Filídios lanceolados ou oblongo-lanceolados, côncavos, margem na porção mediana superior recurvada, ápice acuminado, células 2-4:1, lisas, parede celular lisas, células alares diferenciadas (infladas e coloridas), células supraalares infladas. Peristômio duplo, dentes do peristômio estriados abaixo, células do exotécio colenquimatosas, propagação vegetativa não conhecida.

Material examinado: Minas Gerais, Conceição do Mato Dentro, O. Yano 504 (SP135467); Congonhas do Norte, Pirani et al. 4150 p.p. (SP386336, SPF); Jaboticatubas, Pirani et al. 6296 p.p. (SP432416, SPF); Santana do Riacho, $O$. Yano \& Wanderley 10612, 10613 p.p., 10623, 10714, 10780, 10801, 10836, 10839 p.p. (SP220307; SP220308; SP220318; SP220409; SP220473; SP220494; SP220529; SP220532); Câmara 1855, 1857, 1877, 1882 (SP419626; SP419628; SP419635; SP419636); Câmara et al. 2055, 2072 (SP419698; SP419705); Dias Neto 70 (SP419725); Dias Neto 100, 111, 114, 118, 127 (SP419738; SP419748; SP419751; SP419753; SP419760).

Associada a Cheilolejeunea discoidea (Lehm. \& Lindenb.) Kachroo \& R.M. Schust., C. holostipa (Spruce) Grolle \& R.-L. Zhu, C. unciloba (Lindenb.) Malombe e Lejeunea flava (Sw.) Nees. Ocorre nos estados de AC, AL, AP, AM, BA, CE, ES, DF, GO, MG, MT, MS, PA, PB, PE, PR, RJ, RO, RR, RS, SC, $\mathrm{SP}$ e TO. Na Serra do Cipó, cresce em tronco vivo. Esta é a espécies mais comum e amplamente distribuída do gênero, quando secos os gametófitos adquirem aspecto falcados.

5.8. Sematophyllum subsimplex (Hedw.) Mitt., J. Linn. Soc. Bot. 12: 494. 1869.

Fig. $32 \mathrm{O}-\mathrm{U}$

Gametófitos pequenos, ramos ascendentes igualmente foliados, quando secos prostrados. Caulídios avermelhados. Filídios lanceolados, planos, margem na porção mediana superior plana, ápice cuspidado, células lineares, lisas, parede celular lisas, células alares diferenciadas (infladas e coloridas), células supra-alares não infladas. Peristômio duplo, dentes do peristômio estriados abaixo, células do exotécio colenquimatosas, propagação vegetativa não conhecida.

Material examinado: Minas Gerais, Conceição do Mato Dentro, O. Yano 480 p.p. (SP135452); Santana do Riacho, J.R. Pirani et al. 10288 (SP230727, SPF); O. Yano \& Wanderley 10624, 10703, 10733, 10776, 10797, 10882 (SP220319; SP220398; SP220427; SP220469; SP220490; SP220575); Câmara 1858, 1894, 1900, 2021 (SP419629; SP419641; SP419643; SP419693); Dias Neto 171, 222, 247 (SP419789; SP419821; SP419831).

Associada a Callicostella pallida (Hornsch.) Ångstr. Ocorre nos estados de AC, AL, AM, AP, BA, CE, ES, DF, GO, MA, MG, MS, MT, PA, PB, PE, PI, PR, RJ, RO, RR, SP, SE, TO, RS e SC. Na Serra do Cipó, cresce em solo, tronco caído e vivo. Esta é uma espécie muito comum e caracteristicamente relacionada a áreas que sofrem de estresse hídrico. $\mathrm{O}$ hábito desta espécie é comumente aplainado. 


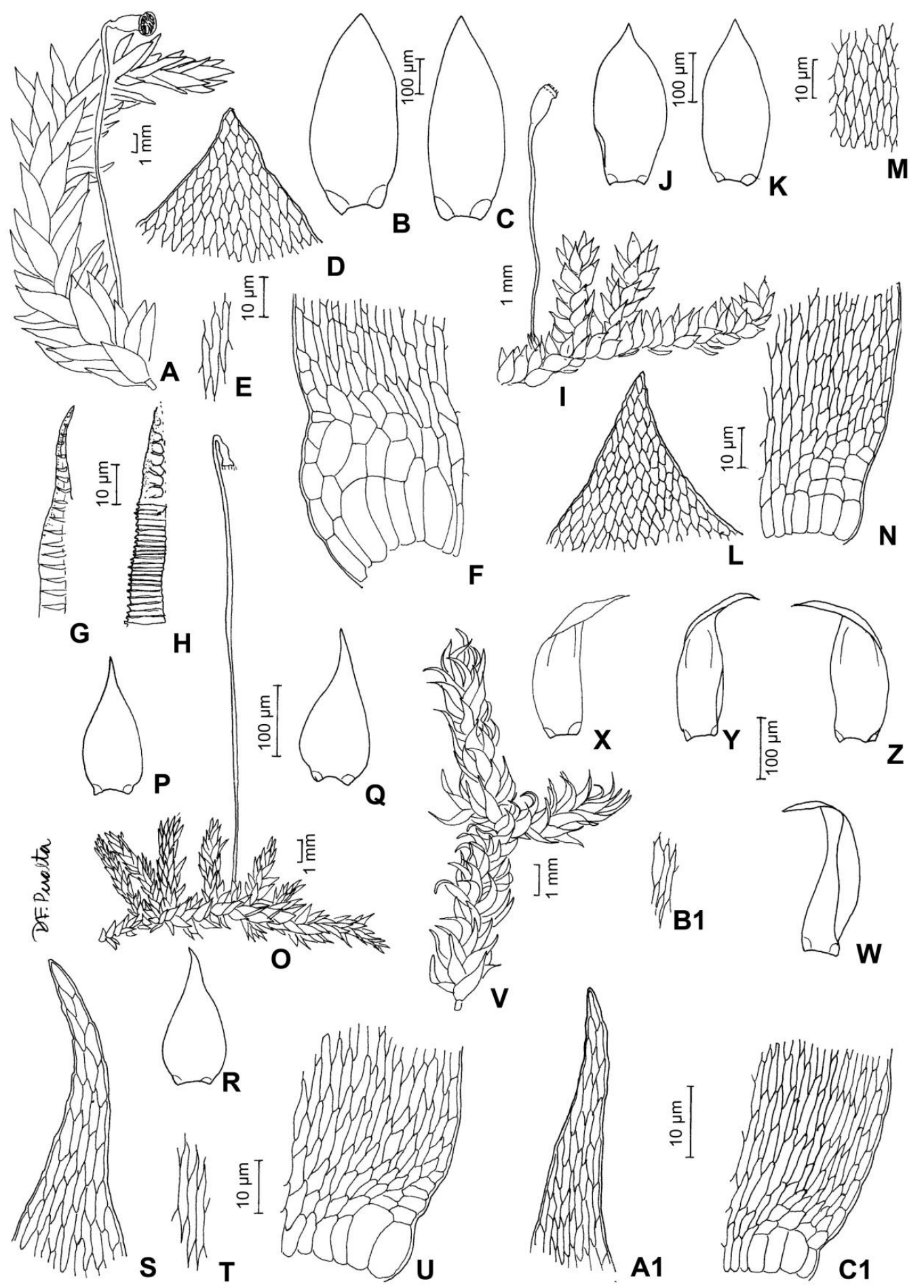

Fig. 32. Sematophyllum subdepressum (Hampe) Broth. A. aspecto do gametófito. B-C. filídios. D. células do ápice do filídio. E. células da lâmina do filídio. F. células da base do filídio. G. dente do endóstomo. H. dente do exóstomo. Sematophyllum subpinnatum (Brid.) E. Britton. I. aspecto do gametófito. J-K. filídios. L. células do ápice do filídio. M. células da lâmina do filídio. N. células da base do filídio. Sematophyllum subsimplex (Hedw.) Mitt. O. aspecto do gametófito. P-R. filídios. S. células do ápice do filídio. T. células da lâmina do filídio. U. células da base do filídio. Sematophyllum swartzii (Schwägr.) Welch \& H.A. Crum. V. aspecto do gametófito. X-W. filídios. A1. células do ápice do filídio. B1. células da lâmina do filídio. C1. células da base do filídio (A-H. Vital 1239; I-N. O. Yano 504; O-U. O. Yano \& Wanderley 10624; V-C1. Câmara 1991). 
Flora da Serra do Cipó, Minas Gerais: Briófitas (Anthocerotophyta, Bryophyta e Marchantiophyta)

5.9. Sematophyllum swartzii (Schwägr.) Welch \& H.A. Crum, Bryologist 62(3): 176. 1959.

Fig. $32 \mathrm{~V}-\mathrm{C} 1$

Gametófitos medianos, ramos ascendentes igualmente foliados, quando secos prostrados, caulídios amarronzados. Filídios lanceolados, falcados, margem na porção mediana superior recurvada, ápice acuminado, células lineares, lisas, parede celular lisas, células alares diferenciadas (infladas e coloridas), células supra-alares infladas. Peristômio duplo, dentes do peristômio estriados abaixo, células do exotécio colenquimatosas, propagação vegetativa não conhecida.

Material examinado: Minas Gerais, Santana do Riacho, Prado s.n. (SP220626); Câmara 1991, 2003, 2011 (SP419685; SP419687; SP419690); Dias Neto 251, 252, 255 (SP419834; SP419835; SP419838).

Ocorre nos estados de BA, ES, MG, RJ e RS. $\mathrm{Na}$ Serra do Cipó, cresce em tronco caído. Esta é a única espécie do gênero que apresenta os filídios falcados, pode ser confundida com Trichosteleum glaziovii (Hampe) W.R. Buck que também apresenta os filídios falcados, porém T. glaziovii apresenta uma papila nas células do filídio.

\section{Wijkia H.A. Crum}

Gametófitos pleurocárpicos, medianos, formando tapetes. Caulídios primários prostrados, poucos rizóides, ramos secundários ascendentes. Filídios lanceolados, côncavos, espiralados, quando secos imbricados, base do filídio auriculada. Costa ausente, ápice do filídio acuminado, margem do filídio plana, inteira, não bordeada, células da lâmina longohexagonais, lisas, parede celular delgada, reta, células da base do filídio 1-10 fileira de células, muito infladas, marrons a laranja. Seta longa, reta, lisa. Cápsula ereta, assimétrica, urna ovóide, rômbica, ânulo presente. Opérculo rostrado. Peristômio duplo. Caliptra glabra.

6.1. Wijkia flagellifera (Broth.) H.A. Crum, Bryologist 74(2): 172. 1971.

Fig. $33 \mathrm{~A}-\mathrm{H}$

Gametófitos pequenos, ramos ascendentes com os filídios diminuindo gradualmente de tamanho em direção ao ápice, quando secos ascendentes, caulídios amarronzados. Filídios lanceolados, planos, margem na porção mediana superior plana, ápice cuspidado, células 5-10:1, lisas, parede celular lisas, células alares pouco diferenciadas (quadráticas) ou diferenciadas (infladas e coloridas), células supraalares não infladas. Peristômio duplo, dentes do peristômio estriados abaixo, células do exotécio não colenquimatosas, propagação vegetativa por ramos caducos.

Material examinado: Minas Gerais, Conceição do Mato Dentro, Vital 1249 (SP87130); Santana do Riacho, Serra da Bandeirinha, Prado s.n. (SP220627); Câmara 2014 (SP419691).

Ocorre nos estados de BA, ES, MG, PE, PR, RJ, RS, SC e SP. Na Serra do Cipó, cresce em tronco caído e vivo. Esta é uma espécie facilmente identificada por apresentar inúmeros ramos flageliformes eretos sobre os ramos, esta característica é visualizada mesmo em campo.

\section{Sphagnaceae}

É uma família amplamente distribuída no Brasil, caracterizada principalmente pela coloração esbranquiçada e pelos ramos agrupados no ápice formando um capítulo. Ocorre principalmente como terrícola, comumente associado a cursos de água ou locais encharcados. Para a identificação das espécies é necessário secção transversal e análise da morfologia das células da lâmina do filídio e caulídio. A família possui somente um gênero e no Brasil ocorrem 112 espécies; na Serra do Cipó ocorrem 11 espécies. Bibliografia básica - Crum (1994); Gradstein et al. (2001); Sharp et al. (1994); Yano \& Peralta (2009); Yano et al. (1985).

\section{Sphagnum L.}

Gametófitos cladocárpicos. Medianos ou robustos, formando tufos. Caulídios primários eretos, poucos rizóides, ramos secundários fascículos. Filídios ligulados ou lanceolados ou ovados. Côncavos. Espiralados, quando secos imbricados. Costa ausente. Secção transversal leucocistos e clorocistos intercalados (sphagnóide), ápice do filídio obtuso ou agudo ou truncado, margem do filídio plana, inteira ou denticulada, não bordeada ou bordeada (ca. 10-15:1 compr.), células da lâmina longo-hexagonais ou lineares, lisas, parede celular com reforços de fibrilas, sinuosa, células da base do filídio iguais as da lâmina. Dióicos. Pseudopódio, curto, reto, incolor, liso. Cápsula ereta, simétrica, urna ovóide ou sub-cilíndrica, rômbica, superfície lisa quando seca. Opérculo cônico. Peristômio ausente. Caliptra glabra, lisa. 


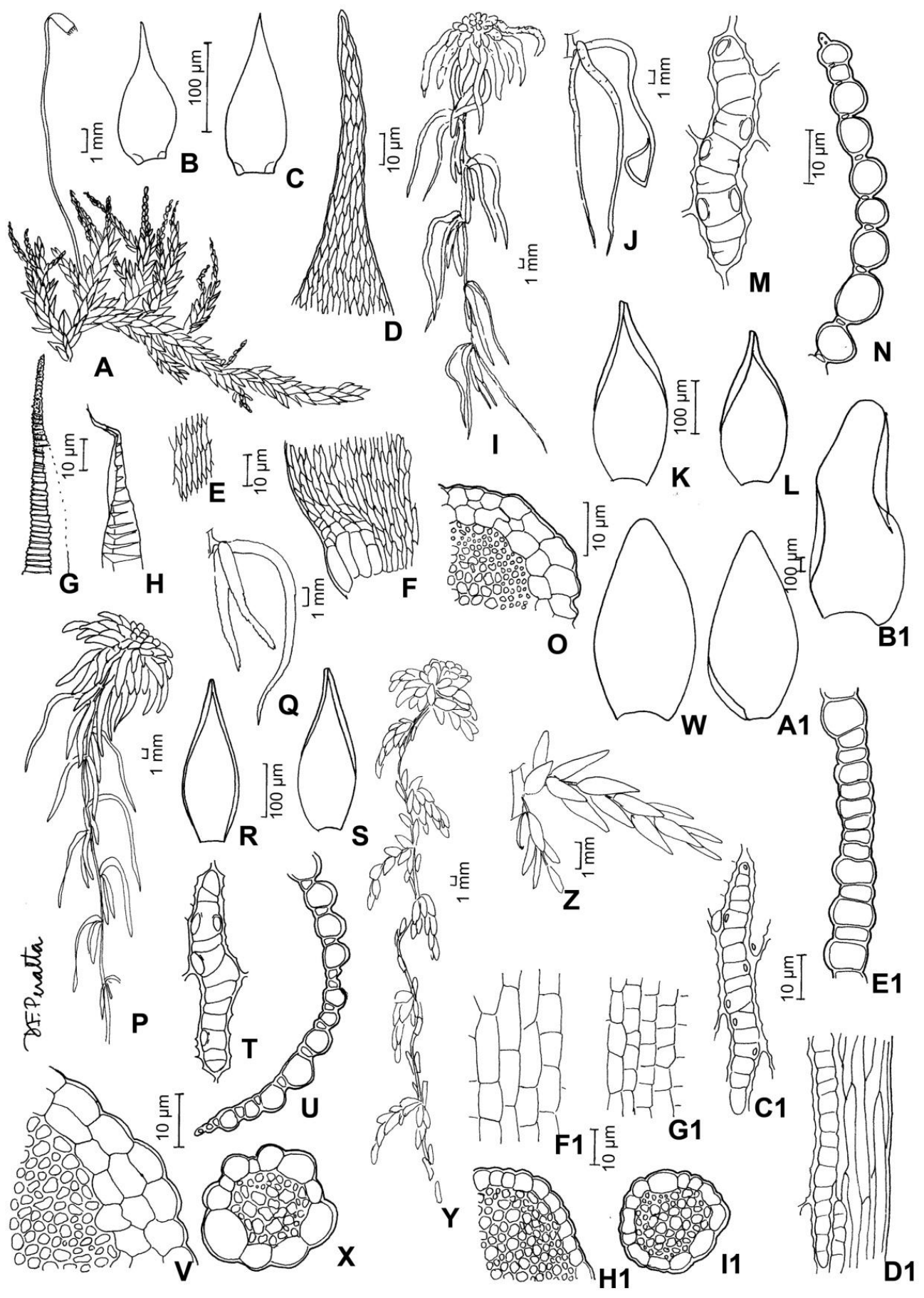

Fig. 33. Wijkia flagellifera (Broth.) H.A. Crum. A. aspecto do gametófito. B-C. filídios. D. células do ápice do filídio. E. células da lâmina do filídio. F. células da base do filídio. G. dente do exóstomo. H. dente do endóstomo. Sphagnum capillifolium (Ehrh.) Hedw. I. aspecto do gametófito. J. detalhe do ramo. K-L. filídios. M. células da lâmina do filídio. N. secção transversal do filídio. Sphagnum cuspidatum Ehrh. ex Hoffm. P. aspecto do gametófito. Q. detalhe do ramo. R-S. filídios. T. células da lâmina do filídio. U. secção transversal do filídio. V. secção transversal do caulídio. X. secção transversal do ramo. Sphagnum cuspidatum var. serrulatum (Schliep.) Schliep. Y. aspecto do gametófito. Z. detalhe do ramo. W-B1. filídios. C1. células da lâmina do filídio. D1. células da margem do filídio. E1. secção transversal do filídio. F1. células corticais do caulídio. G1. células corticais do ramo. H1. secção transversal do caulídio. I1. secção transversal do ramo (A-H. Vital 1249; I-N. Vital 7621; P-X. Pirani et al. 9750; Y-11. O. Yano 540). 
Flora da Serra do Cipó, Minas Gerais: Briófitas (Anthocerotophyta, Bryophyta e Marchantiophyta)

Chave para as espécies

1. Clorocistos em secção transversal igualmente expostos.

2. Filídios oblongo-ovados a lanceolados; gametófitos medianos; muitos poros pequenos em toda a margem; ramos delicados e estreitos

3. Poros restritos à margem dos leucocistos

1.11. S. subsecundum

3'. Poros marginais e sobre os leucocistos 1.9. S. pluriporosum

2'. Filídios ovados a suborbiculares; gametófitos grandes; poucos poros grandes, concentrados nos ângulos; ramos grandes e turgidos.

4, Ápice dos filídios agudo...

4'. Ápice dos filídios obtuso.

5. Leucocistos largos, ca. 3-4:1 compr.; parede celular interna entre leucocistos e clorocistos lisa;

5'. Leucocistos estreitos, ca. 6-10:1; parede celular interna entre leucocistos e clorocistos papilosa;

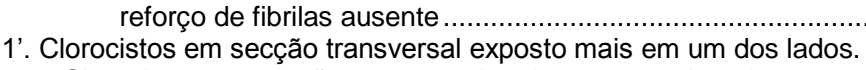

6. Clorocistos em secção transversal mais expostos dorsalmente ...................................................... 1.2. S. cuspidatum

6'. Clorocistos em secção transversal mais expostos ventralmente.

7. Filídios lanceolados 1.5. S. oxyphyllum

7'. Filídios oblongo-lanceolados a ovado ou suborbiculares.

8. Filídios oblongo-ovados.

9. Muitos poros pequenos em toda a margem; ápice dos filídios agudo; células corticais do caulídio em camada simples

1.4. S. magellanicum

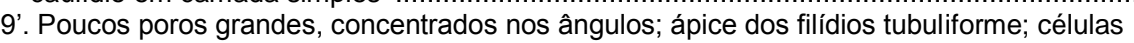
corticais do caulídio em várias camadas

1.10. S. sparsum

Filídios ovados a suborbiculares.

10. Gametófitos grandes; poucos poros grandes, concentrados nos ângulos; ramos verticilados grandes e túrgidos; células corticais do caulídio em várias camadas ......

10'. Gametófitos medianos; muitos poros pequenos em toda a margem; ramos verticilados ausentes; células corticais do caulídio em camada simples 1.6. S. palustre 1.3. S. cyclophyllum

1.1. Sphagnum capillifolium (Ehrh.) Hedw., Fund. Musc. 2: 86. 1782.

Fig. $33 \mathrm{I}-\mathrm{N}$

Gametófitos medianos. Filídios oblongo-ovados a lanceolados, côncavos, clorocistos em secção transversal mais expostos ventralmente, formato triangular, parede celular interna entre leucocistos e clorocistos lisa, leucocistos estreitos, ca. 6-10:1, poucos poros grandes, concentrados nos ângulos, ápice dos filídios tubuliforme, margem bordeada por células lineares, ramos delicados e estreitos, células corticais do caulídio várias camadas, reforço de fibrilas ausente, células corticais dos ramos dimórficas: grandes e porosas alternando com pequenas.

Material examinado: Minas Gerais, Itambé do Mato Dentro, Vital 7621 (SP136576); Conceição do Mato Dentro, Vital 1237 (SP88503); Santana do Riacho, Pirani et al. 12037 (SPF171256); Câmara et al. 2084, 2130 (SP419706; SP419716).
Ocorre nos estados de AM, BA, MG, MS, PR, RJ, RS, SC e SP. Na Serra do Cipó, cresce em solo. Esta espécie apresenta os filídios dos ramos caracteristicamente tubuliforme (capilar) e coloração fortemente vermelho a vináceo.

1.2. Sphagnum cuspidatum Ehrh. ex Hoffm. var. cuspidatum, Deutschl. Flora 2: 22. 1796.

Fig. 33 P-X

Gametófitos grandes. Filídios lanceolados ou oblongo-ovados a lanceolados, planos, clorocistos em secção transversal mais expostos dorsalmente, formato triangular, parede celular interna entre leucocistos e clorocistos lisa, leucocistos estreitos, ca. 6-10:1, poucos poros grandes, concentrados nos ângulos, ápice dos filídios agudo ou tubuliforme, margem bordeada por células lineares, ramos delicados e estreitos, células corticais do caulídio várias camadas, reforço de fibrilas ausente, células corticais dos ramos dimórficas: grandes e porosas alternando com pequenas. 
Material examinado: Minas Gerais, Santana do Riacho, Pirani et al. 9750 (SP222545, SPF42412).

Ocorre nos estados de MG, PR, RJ, RS, SC e SP. Na Serra do Cipó, cresce na margem do riacho.

1.2.1 Sphagnum cuspidatum var. serrulatum (Schliep.) Schliep., Irmischia 2: 67. 1882.

Fig. 33 Y-I1

Gametófitos grandes. Filídios lanceolados, planos, clorocistos em secção transversal mais expostos dorsalmente, formato triangular, parede celular interna entre leucocistos e clorocistos lisa, leucocistos estreitos, ca. 6-10:1, poucos poros grandes, concentrados nos ângulos, ápice dos filídios agudo, margem bordeada por células lineares, ramos delicados e estreitos, células corticais do caulídio várias camadas, reforço de fibrilas ausente, células corticais dos ramos dimórficas: grandes e porosas alternando com pequenas.

Material examinado: Minas Gerais, Conceição do Mato Dentro, O. Yano 540 (SP135494).

Ocorre no estado de RJ (Itatiaia; Petrópolis, Morro Açu). Na Serra do Cipó, cresce em solo. Esta variedade assemelha-se a uma forma estiolada da espécie típica, com os filídios alongados e espaçados.

1.3. Sphagnum cyclophyllum Sull. \& Lesq., Musci Bor. Amer.: 4. 1856.

Fig. 34 A-F

Gametófitos medianos. Filídios ovados a suborbiculares, côncavos, clorocistos em secção transversal mais expostos ventralmente, formato triangular, parede celular interna entre leucocistos e clorocistos lisa, leucocistos estreitos, ca. 6-10:1, muitos poros pequenos em toda a margem, ápice dos filídios obtuso, margem bordeada por células lineares, ramos ausentes, células corticais do caulídio camada simples, reforço de fibrilas ausente.

Material examinado: Minas Gerais, Itambé do Mato Dentro, Vital 7613 (SP136569); Santana do Riacho, Pirani et al. 12386 (SP386337, SPF).

Ocorre nos estados de DF, MG, PR, RJ, SC e SP. Na Serra do Cipó, cresce em solo. Esta foi a única espécie das encontradas na Serra que não apresentava ramos.

1.4. Sphagnum magellanicum Brid., Musc. Rec. 2(1): 24. 1798.

Fig. 34 G-R

Gametófitos grandes. Filídios ovados a suborbiculares, côncavos, clorocistos em secção transversal igualmente expostos, formato elíptico, parede celular interna entre leucocistos e clorocistos lisa, leucocistos largos, ca. 3-4:1 compr., poucos poros grandes, concentrados nos ângulos, ápice dos filídios agudo, margem bordeada por células lineares, ramos grandes e turgidos, células corticais do caulídio várias camadas, reforço de fibrilas presente, células corticais dos ramos todas semelhantes.

Material examinado: Minas Gerais, Conceição do Mato Dentro, Vital 1219 (SP88726); O. Yano 523 (SP135481).

Ocorre nos estados de AM, BA, DF, ES, MG, MS, PR, RJ, RO, RR, RS, SC e SP. Na Serra do Cipó, cresce em solo e rocha. Esta é a espécie que apresenta $o$ hábito mais robusto de todas as encontradas.

\subsection{Sphagnum oxyphyllum Warnst., Hedwigia} 29: 192. 1890.

Fig. 34 S-B1

Gametófitos medianos. Filídios lanceolados, côncavos, clorocistos em secção transversal mais expostos ventralmente, formato triangular, parede celular interna entre leucocistos e clorocistos lisa, leucocistos estreitos, ca. 6-10:1, poucos poros grandes, concentrados nos ângulos, ápice dos filídios tubuliforme, margem bordeada por células lineares, ramos delicados e estreitos, células corticais do caulídio várias camadas, reforço de fibrilas ausente, células corticais dos ramos dimórficas: grandes e porosas alternando com pequenas.

Material examinado: Minas Gerais, Itambé do Mato Dentro, Vital 7616, 7618 (SP136571; SP136573).

Ocorre nos estados de ES, MG, RJ, SC e SP. Na Serra do Cipó, cresce em rocha.

1.6. Sphagnum palustre L., Spec. Plant. ed. 2: 1106. 1753.

Fig. 34 C1-N1

Gametófitos grandes. Filídios ovados a suborbiculares, côncavos, clorocistos em secção transversal mais expostos ventralmente, formato triangular, parede celular interna entre leucocistos e clorocistos lisa, leucocistos largos, ca. 3-4:1 compr., poucos poros grandes, concentrados nos ângulos, ápice dos filídios obtuso, margem não bordeada, ramos grandes e turgidos, células corticais do caulídio várias camadas, reforço de fibrilas presente, células corticais dos ramos todas semelhantes.

Material examinado: Minas Gerais, Conceição do Mato Dentro, O. Yano 519 (SP135477); Santana do Riacho, O. Yano \& Wanderley 10694, 10844, 10907, 10911 (SP220389; SP220537; SP220600; SP220604); Congonhas do Norte, Pirani et al. 5125, 5640, 5771 (SP379507, SPF; SP389357 SPF; SP432343, SPF); Dias Neto 216 (SP419820). 
Flora da Serra do Cipó, Minas Gerais: Briófitas (Anthocerotophyta, Bryophyta e Marchantiophyta)

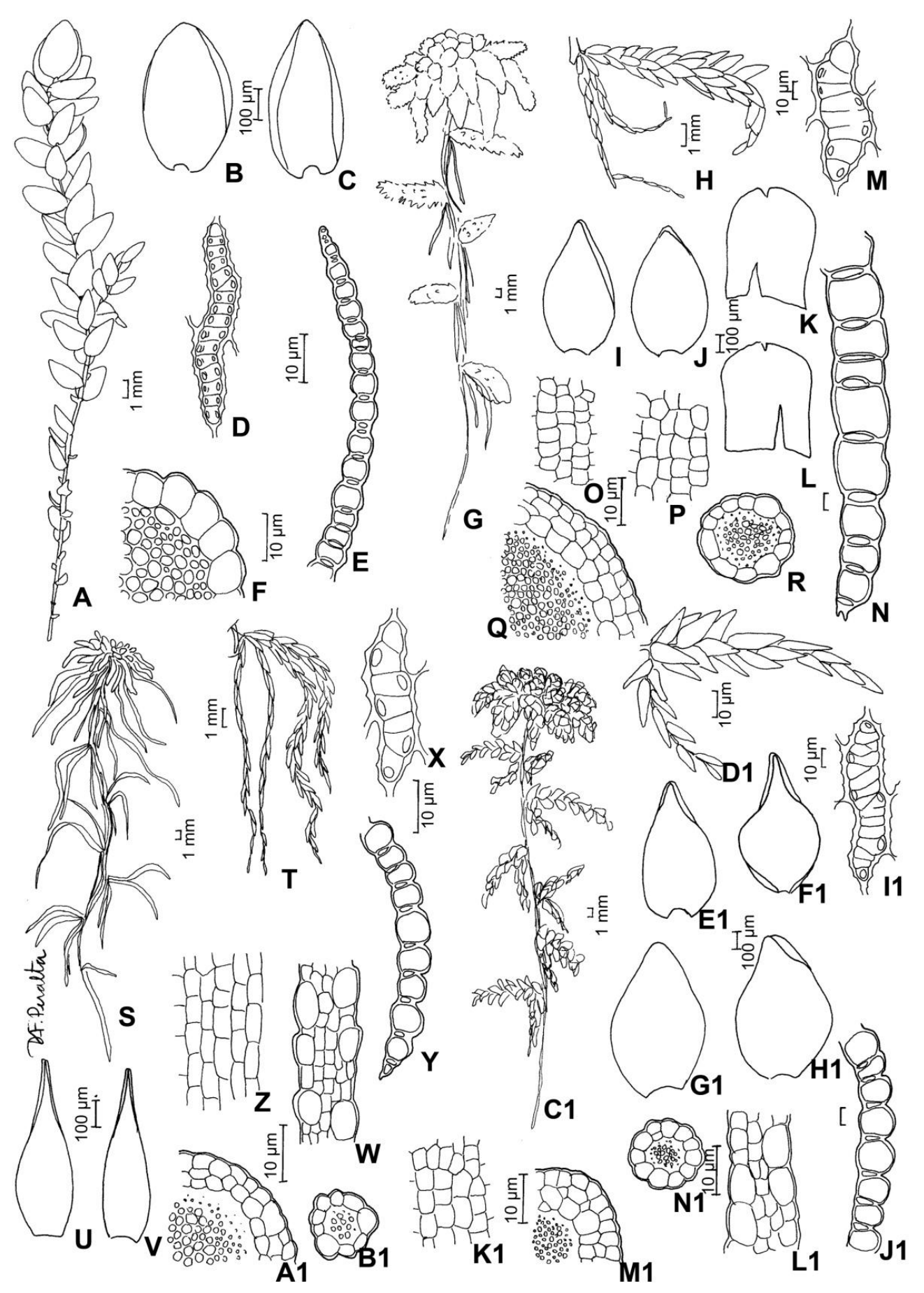

Fig. 34. Sphagnum cyclophyllum Sull. \& Lesq. A. aspecto do gametófito. B-C. filídios. D. células da lâmina do filídio. E. secção transversal do filídio. F. secção transversal do caulídio. Sphagnum magellanicum Brid. G. aspecto do gametófito. $\mathrm{H}$. detalhe do ramo. I-J. filídios. K-L. filídios do caulídio. M. células da lâmina do filídio. N. secção transversal do filídio. O. células corticais do caulídio. P. células corticais do ramo. Q. secção transversal do caulídio. R. secção transversal do ramo. Sphagnum oxyphyllum Warnst. S. aspecto do gametófito. T. detalhe do ramo. U-V. filídios. X. células da lâmina do filídio. Y. secção transversal do filídio. Z. células corticais do caulídio. W. células corticais do ramo. A1. secção transversal do caulídio. B1. secção transversal do ramo. Sphagnum palustre L. C1. aspecto do gametófito. D1. detalhe do ramo. E1-H1. filídios. I1. células da lâmina do filídio. J1. secção transversal do filídio. K1. células corticais do caulídio. L1. células corticais do ramo. M1. secção transversal do caulídio. N1. secção transversal do ramo (A-F. Vital 7613; G-R. Vital 1219; S-B1. Vital 7616; C1-N1. O. Yano 519). 
Ocorre nos estados de AM, AP, BA, CE, ES, GO, MG, MS, PA, PB, PE, PR, RJ, RO, RR, RS, SC, SE e SP. Na Serra do Cipó, cresce em solo e rocha.

1.7. Sphagnum papillosum Lindb., Acta Soc. Sci. Fenn. 10: 280. 1872.

Fig. 35 A-G

Gametófitos grandes. Filídios ovados a suborbiculares, côncavos, clorocistos em secção transversal igualmente expostos, formato elíptico, parede celular interna entre leucocistos e clorocistos papilosa, leucocistos estreitos, ca. 6-10:1, poucos poros grandes, concentrados nos ângulos, ápice dos filídios obtuso, margem bordeada por células lineares, ramos grandes e turgidos, células corticais do caulídio várias camadas, reforço de fibrilas ausente, células corticais dos ramos todas semelhantes.

Material examinado: Minas Gerais, Congonhas do Norte, Amaral s.n. (SP172179).

Ocorre nos estados de BA, MG, MT e RJ. Na Serra do Cipó, cresce em solo. Esta foi a única espécie que apresentou papilas na porção interna dos leucocistos.

1.8. Sphagnum perichaetiale Hampe, Linnaea 20: 66. 1847.

Fig. $35 \mathrm{H}-\mathrm{P}$

Gametófitos grandes. Filídios ovados a suborbiculares, côncavos, clorocistos em secção transversal igualmente expostos, formato elíptico, parede celular interna entre leucocistos e clorocistos lisa, leucocistos largos, ca. 3-4:1 compr., poucos poros grandes, concentrados nos ângulos, ápice dos filídios obtuso, margem bordeada por células lineares, ramos grandes e turgidos, células corticais do caulídio várias camadas, reforço de fibrilas presente, células corticais dos ramos todas semelhantes.

Conceição do Mato Dentro, Vital 1238 (SP88507); Santana do Riacho, Pirani et al. 10287 (SP230724, SPF171254); Pirani et al. 10376 (SP230731, SPF171255); O. Yano \& Wanderley 10647 (SP220342); O. Yano \& Wanderley 10693 (SP220388); Pirapara, Starling s.n. (SP368141).

Ocorre nos estados de AM, BA, GO, MG, PA, RO, MS, ES, SC, DF, RJ, RS, SP e TO. Na Serra do Cipó, cresce em solo e rocha.

1.9. Sphagnum pluriporosum H.A. Crum, J. Hattori Bot. Lab. 77: 246. 1994.

Fig. $35 \mathrm{Q}-\mathrm{Z}$

Gametófitos medianos. Filídios oblongo-ovados a lanceolados, côncavos, clorocistos em secção transversal igualmente expostos, formato elíptico, parede celular interna entre leucocistos e clorocistos lisa, leucocistos estreitos, ca. 6-10:1, muitos poros pequenos em toda a margem, ápice dos filídios agudo, margem bordeada por células lineares, ramos delicados e estreitos, células corticais do caulídio camada simples, reforço de fibrilas ausente, células corticais dos ramos dimórficas: grandes e porosas alternando com pequenas.

Material examinado: Minas Gerais, Conceição do Mato Dentro, Vital 7578 (SP136549, Isótipo).

Ocorre nos estados de MG e SC. Na Serra do Cipó, cresce em rocha. Esta espécie é conhecida apenas para a Serra do Cipó apenas pelo material tipo descrito, não sendo coletada recentemente.

1.10. Sphagnum sparsum Hampe, Vidensk. Meddel. Naturhist. For. Kjøbenhvan. ser. 3, 2: 259. 1870.

Fig. 35 W-K1

Gametófitos medianos. Filídios oblongo-ovados a lanceolados, côncavos, clorocistos em secção transversal mais expostos ventralmente, formato triangular, parede celular interna entre leucocistos e clorocistos lisa, leucocistos estreitos, ca. 6-10:1, muitos poros pequenos em toda a margem, ápice dos filídios agudo, margem bordeada por células lineares, ramos delicados e estreitos, células corticais do caulídio camada simples, reforço de fibrilas ausente, células corticais dos ramos dimórficas: grandes e porosas alternando com pequenas.

Material examinado: Minas Gerais, Santana do Riacho, O. Yano \& Wanderley 10690, 10692, 10696, 10697 p.p., 19014 (SP220385; SP220387; SP220391; SP220392; SP220607).

Associada a Paracromastigum pachyrrhizon (Nees) Fulford. Ocorre nos estados de BA, RJ e SP. $\mathrm{Na}$ Serra do Cipó, cresce em solo. Esta é a primeira ocorrência em Minas Gerais.

1.11. Sphagnum subsecundum Nees in Sturm, Deutschl. Flora Cryptog. 2(17): 3. 1819.

Fig. 36 A-K

Gametófitos medianos. Filídios oblongo-ovados a lanceolados, côncavos, clorocistos em secção transversal igualmente expostos, formato elíptico, parede celular interna entre leucocistos e clorocistos lisa, leucocistos estreitos, ca. 6-10:1, muitos poros pequenos em toda a margem, ápice dos filídios agudo, margem bordeada por células lineares, ramos delicados e estreitos, células corticais do caulídio camada simples, reforço de fibrilas ausente, células corticais dos ramos dimórficas: grandes e porosas alternando com pequenas. 


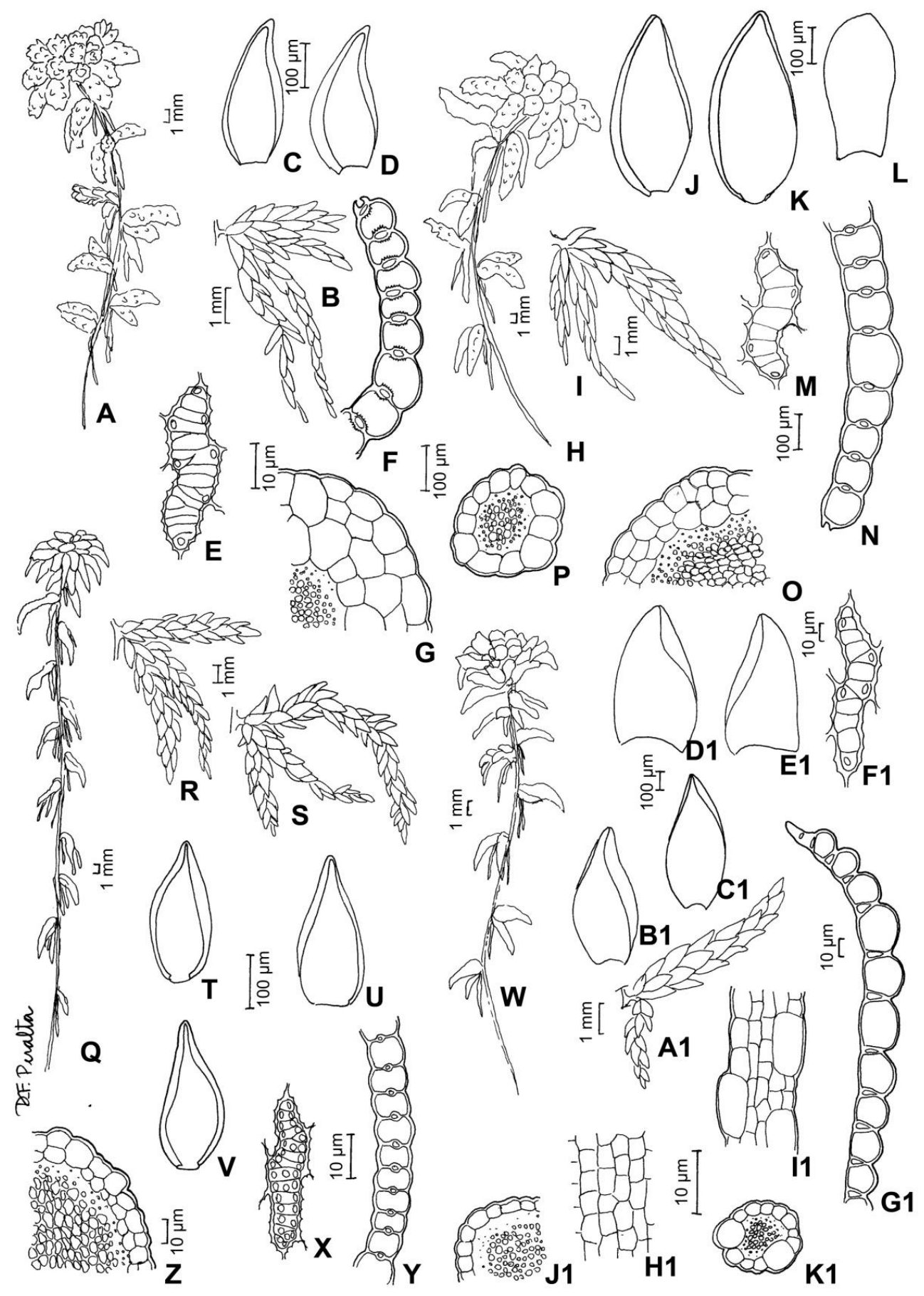

Fig. 35. Sphagnum papillosum Lindb. A. aspecto do gametófito. B. detalhe do ramo. C-D. filídios. E. células da lâmina do filídio. F. secção transversal do filídio. G. secção transversal do caulídio. Sphagnum perichaetiale Hampe. H. aspecto do gametófito. I. detalhe do ramo. J-L. filídios. M. células da lâmina do filídio. N. secção transversal do filídio. O. secção transversal do caulídio. P. secção transversal do ramo. Sphagnum pluriporosum H.A. Crum. Q. aspecto do gametófito. R-S. detalhes do ramo. T-V. filídios. X. células da lâmina do filídio. Y. secção transversal do filídio. Z. secção transversal do caulídio. Sphagnum sparsum Hampe. W. aspecto do gametófito. A1. detalhes do ramo. B1-E1. filídios. F1. células da lâmina do filídio. G1. secção transversal do filídio. H1. células corticais do caulídio. 11. células corticais do ramo. J1. secção transversal do caulídio. K1. secção transversal do ramo (A-G. Amaral s.n.; H-P. Vital 1238; Q-Z. Vital 7578; W-K1. O. Yano \& Wanderley 10690). 
Material examinado: Minas Gerais, Conceição do Mato Dentro, O. Yano 536 (SP135490); Itambé do Mato Dentro, Vital 7622 (SP136577); Jaboticatubas, Pirani et al. 6294 (SP432414, SPF); Santana do Riacho, Cachoeira Farofa, O. Yano \& Wanderley 10638, 10657, 10695, 10912 (SP220333; SP220352; SP220390; SP220605); Pirani et al. 5547, 12038 (SP388845, SPF; SPF171257); Câmara 1909, 1920, 1964 (SP419648; SP419652; SP419675); Dias Neto 214 (SP419818).

Ocorre nos estados de AM, BA, CE, DF, ES, GO, MG, MS, MT, PR, RJ, RR, RS, SC e SP. Na Serra do Cipó, cresce em solo e rocha.

\section{Stereophyllaceae}

Gametófitos pleurocárpicos, medianos, formando tapetes. Caulídios primários prostrados, ramos secundários prostrados, sem paráfilos ou pseudoparáfilos. Filídios ligulados ou lanceolado, assimétricos, planos, aplainados ou espiralados, ápice obtuso ou agudo, margens plana, inteira, não bordeadas. Costa única, até $1 / 2$ ou $3 / 4$ compr. do filídio. Células da lâmina fusiformes, isodiamétricas, lisas ou mamilosas, parede celular delgada, reta, região alar quadrático irregulares. Monóicos ou autóicos. Seta longa, reta, marrom-dourada, lisa. Cápsula exserta, pêndula ou inclinada, assimétrica, urna ovóide ou subcilíndrica, rômbica. Peristômio duplo. Caliptra glabra, não plicada.

É uma família amplamente distribuída no Brasil, caracterizada principalmente pelo hábito prostrado dos caulídios primários e ascendente dos secundários, a costa simples e a região alar assimétrica entre os lados da base. Ocorre principalmente como terrícola e rupícola. Para a identificação das espécies é necessário análise da morfologia das células da lâmina do filídio. No Brasil ocorrem quatro gêneros e oito espécies; na Serra do Cipó ocorrem dois gêneros e duas espécies.

Bibliografia básica - Gradstein et al. (2001); Ireland \& Buck (1994); Sharp et al. (1994); Yano \& Peralta (2009).

\section{Chave para os gêneros}

\section{Entodontopsis Broth.}

Gametófitos pleurocárpicos, medianos, formando tapetes. Caulídios primários prostrados, poucos rizóides, ramos secundários prostrados. Filídios lanceolados, assimétricos, planos, espiralados, planos quando secos. Costa única, 1/2 ou 3/4 compr. do filídio, estreita, ápice do filídio agudo, margem do filídio plana, inteira, não bordeada, células da lâmina longo-hexagonais, lisas, parede celular delgada, reta, células da base do filídio quadrático-irregulares. Seta longa, reta. Cápsula pêndula ou inclinada, assimétrica, urna ovóide, rômbica, superfície lisa quando seca. Opérculo rostrado, peristômio duplo. Caliptra glabra.

1.1. Entodontopsis leucostega (Brid.) W.R. Buck \& Ireland, Nova Hedwigia 41: 103. 1985.

Fig. $36 \mathrm{~L}-\mathrm{Q}$

Gametófitos medianos, formando tapetes. Caulídios primários prostrados, secundários prostrados. Filídios lanceolados, planos, espiralados, planos quando secos. Costa única, 1/2 ou 3/4 compr. do filídio, estreita, ápice do filídio agudo, células da lâmina longo-hexagonais, lisas, parede celular delgada, reta, células da base do filídio quadráticoirregulares, região irregular entre os lados da costa. Seta longa, reta. Cápsula pêndula ou inclinada, assimétrica, urna ovóide, rômbica, superfície lisa quando seca. Opérculo rostrado, peristômio duplo. Caliptra glabra.

Material examinado: Minas Gerais, Santana do Riacho, Dias Neto 132 (SP419764).

Ocorre nos estados do AM, AC, BA, CE, DF, FN, GO, MA, MG, MS, MT, PA, PB, PE, PI, RJ, RO, RR, SP e TO. Na Serra do Cipó, cresce em tronco caído. Esta é uma espécie comum e amplamente distribuída, comumente relacionada a áreas abertas e de cerrado.

\section{Stereophyllum Mitt.}

Gametófitos pleurocárpicos, medianos, formando tapetes. Caulídios primários prostrados, poucos rizóides, ramos secundários prostrados. Filídios ligulados a lanceolados, assimétricos, planos, aplainados, planos quando secos. Costa única, 3/4 compr. do filídio, estreita, ápice do filídio obtuso, margem do filídio plana, inteira, não bordeada, células da lâmina fusiformes, isodiamétricas, unipapilosas, parede celular delgada, reta, células da base do filídio quadrático-irregulares. Seta longa, reta. Cápsula pêndula ou inclinada, assimétrica, urna ovóide, rômbica, superfície lisa quando seca. Opérculo rostrado, peristômio duplo. Caliptra glabra. 


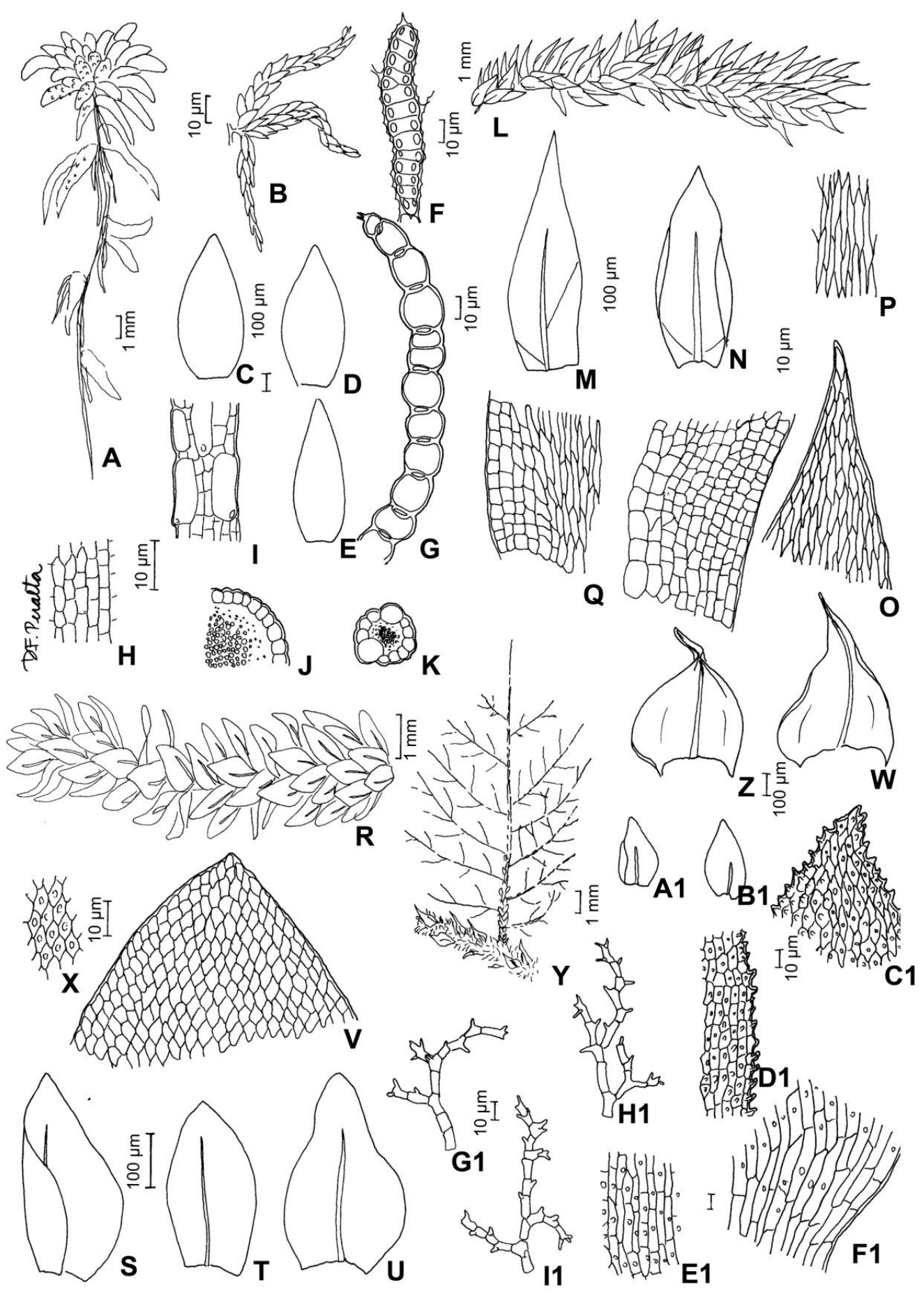

Fig. 36. Sphagnum subsecundum Nees. A. aspecto do gametófito. B. detalhe do ramo. C-E. filídios. F. células da lâmina do filídio. G. secção transversal do filídio. H. células corticais do caulídio. I. células corticais do ramo. J. secção transversal do caulídio. K. secção transversal do ramo. Entodontopsis leucostega (Brid.) W.R. Buck \& Ireland. L. aspecto do gametófito. M-N. filídios. O. células do ápice do filídio. P. células da lâmina do filídio. Q. base do filídio. Stereophyllum radiculosum (Hook.) Mitt. R. aspecto do gametófito. S-U. filídios. V. células do ápice do filídio. X. células da lâmina do filídio. Thuidium pseudoprotensum (Müll. Hal.) Mitt. Y. aspecto do gametófito. Z-W. filídios do caulídio. A1-B1. filídios dos ramos. C1. células do ápice do filídio. D1. células da margem do filídio. E1. células da lâmina do filídio. F1. base do filídio. G1-I1. paráfilos (A-K. O. Yano 536; L-Q. Dias Neto 132; R-X. O. Yano \& Wanderley 10918; Y-I1. Câmara 1949). 
2.1. Stereophyllum radiculosum (Hook.) Mitt., J. Linn. Soc. Bot. 12: 542. 1869.

Fig. $36 \mathrm{R}-\mathrm{X}$

Gametófitos amarelo-esverdeados, complanados a subjuláceos. Filídios oblongo-ovalados a lingulados, simétricos; ápice abruptamente agudo a obtuso, às vezes apiculado; costa evidente até 2/3-3/4 compr. do filídio; células superiores unipapilosas, rombóides, as alares quadráticas, retangulares ou transversalmente alongadas.

Material examinado: Minas Gerais, Santana do Riacho, O. Yano \& Wanderley 10918 (SP220611).

Ocorre nos estados de BA, ES, GO, MG, MS, MT, PA, PR, RJ, RS, SC e SP. Na Serra do Cipó, cresce em rocha. Esta é uma espécie comum e facilmente identificada pelo formato do filídio oblongoligulado e as células da lâmina do filídio fusiformes e unipapilosas.

\section{Thuidiaceae}

\section{Thuidium Bruch \& Schimp.}

Gametófitos pleurocárpicos, pequenos, delicados a medianos. Caulídios primários prostrados, tomentosos, ramos secundários ascendentes ou dendróides, paráfilos, filamentosos ou ramificados, papilosos. Filídios lanceolados. Filídios de dois formatos nos ramos primários e secundários, côncavos, aplainados ou espiralados, quando secos crispados ou imbricados. Costa única, percurrente ou excurrente, estreita, ápice do filídio acuminado ou agudo, margem do filídio plana, denticulada, não bordeada, células da lâmina circulares ou quadráticoirregulares, isodiamétricas, papilosas, parede celular delgada, reta, células da base do filídio iguais as da lâmina. Seta longa, reta. Cápsula exserta, inclinada ou horizontal, assimétrica, urna sub-cilíndrica, rômbica, superfície lisa quando seca. Opérculo rostrado, peristômio duplo. Caliptra glabra.

É uma família amplamente distribuída no Brasil, caracterizada principalmente pelo hábito prostrado dos caulídios primários e dendróide dos secundários, e a presença de paráfilos. Ocorre principalmente como corticícola e rupícola. Para a identificação das espécies é necessário análise da morfologia das células da lâmina do filídio e das paráfilos. No Brasil ocorrem quatro gêneros e 27 espécies; na Serra do Cipó ocorre o gênero Thuidium com uma espécie.

Bibliografia básica - Gradstein et al. (2001); Ireland \& Buck (1994); Sharp et al. (1994); Yano \& Peralta (2009).
1.1. Thuidium pseudoprotensum (Müll. Hal.) Mitt., J. Linn. Soc. Bot. 12: 578. 1869.

Fig. 36 Y-I1

Gametófitos medianos. Caulídios primários prostrados, tomentosos, secundários dendróides, paráfilos, ramificados, papilosos. Filídios lanceolados. Filídios de dois formatos nos ramos primários e secundários, côncavos, espiralados, quando secos crispados. Costa única, excurrente, estreita, ápice do filídio agudo, margem do filídio plana, denticulada, quadrático-irregulares, isodiamétricas, papilosas, parede celular delgada, reta, células da base do filídio iguais as da lâmina. Seta longa, reta. Cápsula exserta, inclinada ou horizontal, assimétrica, urna subcilíndrica, rômbica, superfície lisa quando seca. Opérculo rostrado, peristômio duplo. Caliptra glabra.

Material examinado: Minas Gerais, Santana do Riacho, Câmara 1949 (SP419662).

Ocorre nos estados ES, MG, PR, RJ, RS, SC e SP. Na Serra do Cipó, cresce em rocha.

\section{MARCHANTIOPHYTA}

Os gametófitos desta Divisão apresentam simetria dorsiventral ou bilobulada, podendo ser, dessa maneira folhosos ou talosos. Os filídios nos gametófitos folhosos, chamado nas Marchantiophyta de lobos, não possuem costa, mas algumas vezes possuem células diferenciadas chamadas de vita, nos talosos normalmente são encontradas escamas. As estruturas reprodutivas nos folhosos estão rodeadas por filídios fundidos e sem paráfises, e nos talosos podem estar imersos no talo ou elevados em estruturas pedunculadas. O esporófito é efêmero e se alonga após a diferenciação da cápsula, a parede da cápsula é normalmente delgada e não possui estômatos ou columela. A dispersão dos esporos é comumente realizada pelo ruptura da cápsula (normalmente em quatro valvas) e auxiliada pelos elatérios.

Comumente conhecidos como hepáticas os gametófitos desta Divisão são extremamente comuns, ocorrendo desde os trópicos (onde atingem grande diversidade) até os ambientes árticos, são encontradas em todos os substratos existentes, como rochas, solo, tronco de árvores vivas e mortas, sobre folhas, notavelmente mais abundantes em locais úmidos. Na Região Neotropical existem 41 famílias 188 gêneros e 1350 espécies, no Brasil 39 famílias, 147 gêneros e 988 espécies. 
Flora da Serra do Cipó, Minas Gerais: Briófitas (Anthocerotophyta, Bryophyta e Marchantiophyta)

$\mathrm{Na}$ Serra do Cipó foram encontradas 21 famílias, 47 gêneros e 93 espécies $(9,4 \%$ das espécies que ocorrem no Brasil).

Bibliografia básica: Bastos (2004); Bischler et al. (1963); Bischler-Causse et al. (2005); Costa (1999, 2008); Costa et al. (2010); Engel \& Smith Merrill (2004); Fulford (1963, 1966, 1968, 1976); Gradstein
(1994); Gradstein \& Costa (2003); Gradstein \& IlkiuBorges (2009); Gradstein et al. (2001); Hässel de Menéndez (1962); Heinrichs (2002); Hell (1969); Lemos-Michel (2001); Reiner-Drehwald (2000); Schuster (1980); So (2005); Stotler (1970); Swails Jr. (1970); Yano (2008); Yano \& Peralta (2008); Yuzawa \& Koike (1989); Zartman \& Ilkiu-Borges (2007).

\section{Chave para as famílias}

1. Gametófitos talosos.

2. Gametófitos com margens onduladas formando lobos ondulados a enrugados.

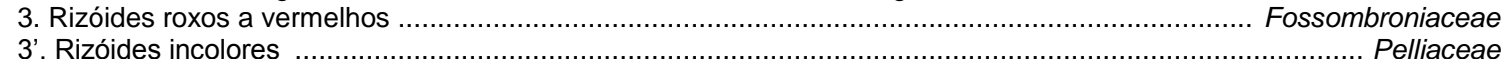

2'. Gametófitos planos, margem às vezes onduladas mas não formando lobos.

4. Região mediana do talo não diferenciada.

5. Gametófitos pequenos e delicados, sem rizóides; esporófitos laterais

5'. Gametófitos grandes, muitos rizóides ou escamas ventrais, esporófitos surgindo em esporangióforos ....

4'. Região mediana do talo diferenciada formando um espessamento.

6. Margem e superfície ventral do talo com pêlos mucilaginosos, sem rizóides ................................... Metzgeriaceae

6'. Margem e superfície ventral sem pêlos, às vezes com rizóides . ....

Aneuraceae

ametófitos folhosos.

7. Anfigastros presentes e evidentes.

8. Filídios com lóbulos.

9. Lóbulos planos ....

Porellaceae

9'. Lóbulos involutos ou em forma de capacete.

10. Maior comprimento do lóbulo perpendicular ao caulídio

10'. Maior comprimento do lóbulo paralelo ao caulídio

Lejeuneaceae

8'. Filídios sem lóbulos.

11. Filídios inteiros.

12. Anfigastros bífidos ou variadamente denteados Jubulaceae

12'. Anfigastros quadrífidos, dois dentes longos e dois menores laterais.

11'. Filídios denteados ou divididos em lobos.

13. Filídios denteados.

14. Filídios com 3 a 4 dentes

14'. Filídios bífidos.

15. Ápice dos filídios bífidos com dois dentes pequenos e próximos

15'. Ápice dos filídios bífidos com dois dentes grandes e distantes.

13'. Filídios divididos em lóbulos

16. Filídios divididos em segmentos laminares

16 '. Filídios divididos em segmentos filiformes

Balantiopsidaceae Geocalycaceae p.p. Pallaviciniaceae

7. Anfigastros ausentes ou muito reduzidos.

17. Filídios com lóbulos

18. Filídios com células hialinas na margem da região apical do lobo, papila hialina presente no lobo...

18'. Filídio sem células hialinas na margem da região apical do lobo, sem papila hialina no lobo

Lepidoziaceae p.p.

Calypogeiaceae Geocalycaceae p.p.

7'. Filídios sem lóbulos.

19. Filídios inteiros.

20. Margem dos filídios denteada.

21. Filídios ligulados a triangulares, perianto ereto-ascentente

21 . Filídios oblongos, perianto projetando-se para o solo

Herbertaceae

Lepidoziaceae p.p.

20'. Margem dos filídios inteira.

22. Células do filídio com parede espessada formando trigônios

22'. Células do filídio com parede delgada.

23. Plantas terrestres, perianto longo-cilíndrico

23'. Plantas corticícolas, perianto em formato de taça

Lejeuneaceae p.p. Radulaceae

19'. Filídios bífidos.

24. Sinus do filídio em forma de $V$

24 '. Sinus do filídio em forma de C Plagiochilaceae Adelanthaceae Cephaloziaceae p.p. Jungermanniaceae Chonecoleaceae

Cephaloziellaceae Cephaloziaceae p.p. 


\section{Adelanthaceae}

Bibliografia básica: Gradstein \& Costa (2003); Gradstein et al. (2001).

\section{Adelanthus Mitt.}

Gametófitos folhosos, marrons ou verdeescuros, estolões presentes, hábito ascendente, ramificações do tipo ventral intercalar. Filídios íncubos, inserção oblíqua, denteada, margem na região ventral decurrente, margem na região dorsal involuta, com células diferenciadas formando vita. Células quadrático-irregulares, parede celular uniformemente espessada, cutícula lisa, trigônios presentes. Ocelos ausentes. Anfigastro ausente, rizóides monomórficos, restritos à base dos ramos, incolores. Gametângios ventrais no caulídio, abaixo dos filídios, anterídios em eixos especializados com filídios modificados, perianto liso. Cápsula alongada. Reprodução vegetativa por gemas na margem dos filídios.

1.1. Adelanthus carabayensis (Mont.) Grolle, J. Hattori Bot. Lab. 35: 348. 1972.

Fig. 37 A-E

Gametófitos folhosos. Filídios íncubos, denteados, margem na região ventral decurrente, margem na região dorsal involuta, com células diferenciadas formando vita. Células quadráticoirregulares, cutícula lisa, trigônios presentes. Anfigastro ausente. Gametângios ventrais no caulídio, abaixo dos filídios, anterídios em eixos especializados com filídios modificados, perianto liso. Cápsula alongada.

Material examinado: Minas Gerais, Santana do Riacho, Dias Neto 139a p.p., 153 p.p. (SP419770; SP419777).

Associada a Cheilolejeunea clausa (Nees \& Mont.) R.M. Schust. e Lepidozia inaequalis Lehm. \& Lindenb. Ocorre nos estados de MG e RJ. Na Serra do
Cipó, cresce em rocha. Esta espécie ocorre comumente sobre rochas na margem de rios com cachoeiras, apresenta $o$ hábito semelhante as espécies da família Plagiochilaceae, porém a formação da cápsula ocorre em direção ao substrato em Adelanthus e ascendente em Plagiochilaceae. Os gametófitos e, Adelanthus apresentam ainda hábito menor e caracteristicamente enegrecidos quando secos.

\section{Aneuraceae}

É uma família amplamente distribuída no Brasil, caracterizada principalmente pelo hábito prostrado dos talos primários e, algumas vezes ascendente dos secundários, o talo simples e sem diferenciação mediana. Ocorre principalmente como terrícola, rupícola e corticícola. Para a identificação das espécies é necessário análise da morfologia da secção transversal do talo. No Brasil ocorrem dois gêneros e 29 espécies; na Serra do Cipó ocorre o gênero Riccardia e duas espécies.

Bibliografia básica: Gradstein \& Costa (2003); Gradstein et al. (2001); Hell (1969); Lemos-Michel (2001).

\section{Riccardia A. Gray}

Gametófitos talosos, pretos ou verde-escuros, estolões ausentes, hábito ascendente ou prostrado, ramificações dicotômicas. Talo irregular ou pinado, sem diferenciação de nervura central, camadas de células não diferenciadas. Células quadráticoirregulares, parede celular uniformemente delgada, cutícula lisa, trigônios ausentes, células da margem iguais as interiores. Ocelos ausentes. Anfigastro ausente, rizóides monomórficos, ao longo de toda a porção ventral, incolores. Gametângios laterais em pequenas ramificações, anterídios em eixos especializados com filídios modificados, arquegônios invólucro, liso. Cápsula alongada. Reprodução vegetativa por ramos geminíferos.

1. Ala ausente, secção transversal com 2-4 células medulares, ramificação irregular

1'. Ala distinta, com 1(2) a várias células, secção transversal com 5-7 células medulares, ramificação bipinada ou irregular 
Flora da Serra do Cipó, Minas Gerais: Briófitas (Anthocerotophyta, Bryophyta e Marchantiophyta)

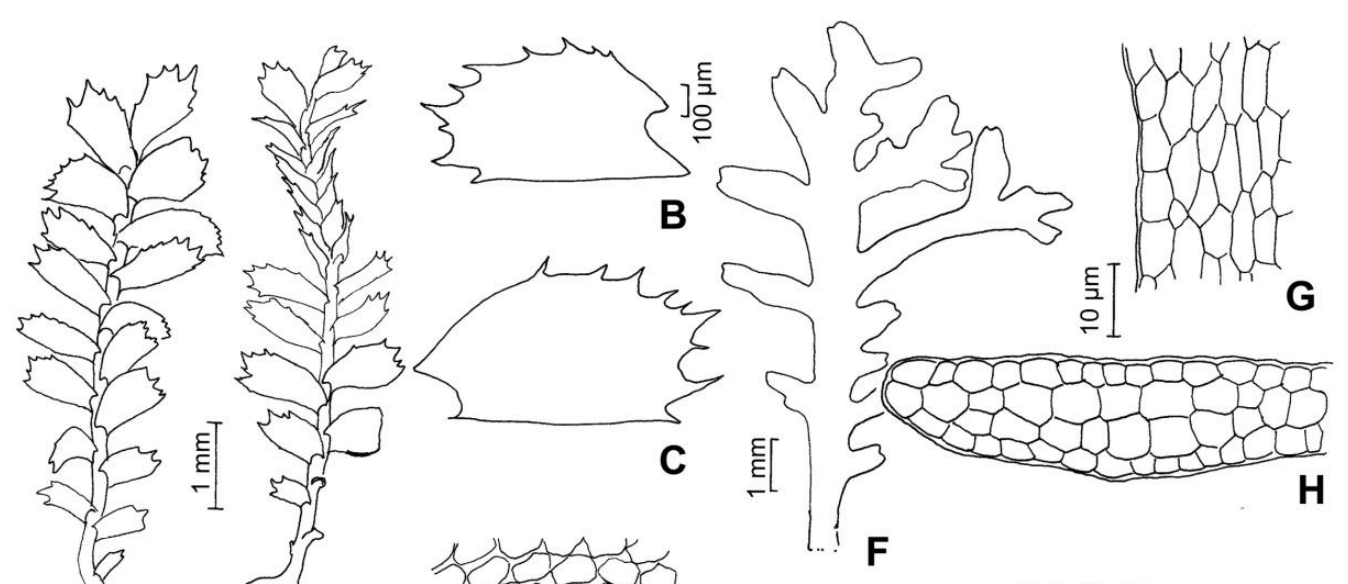

H
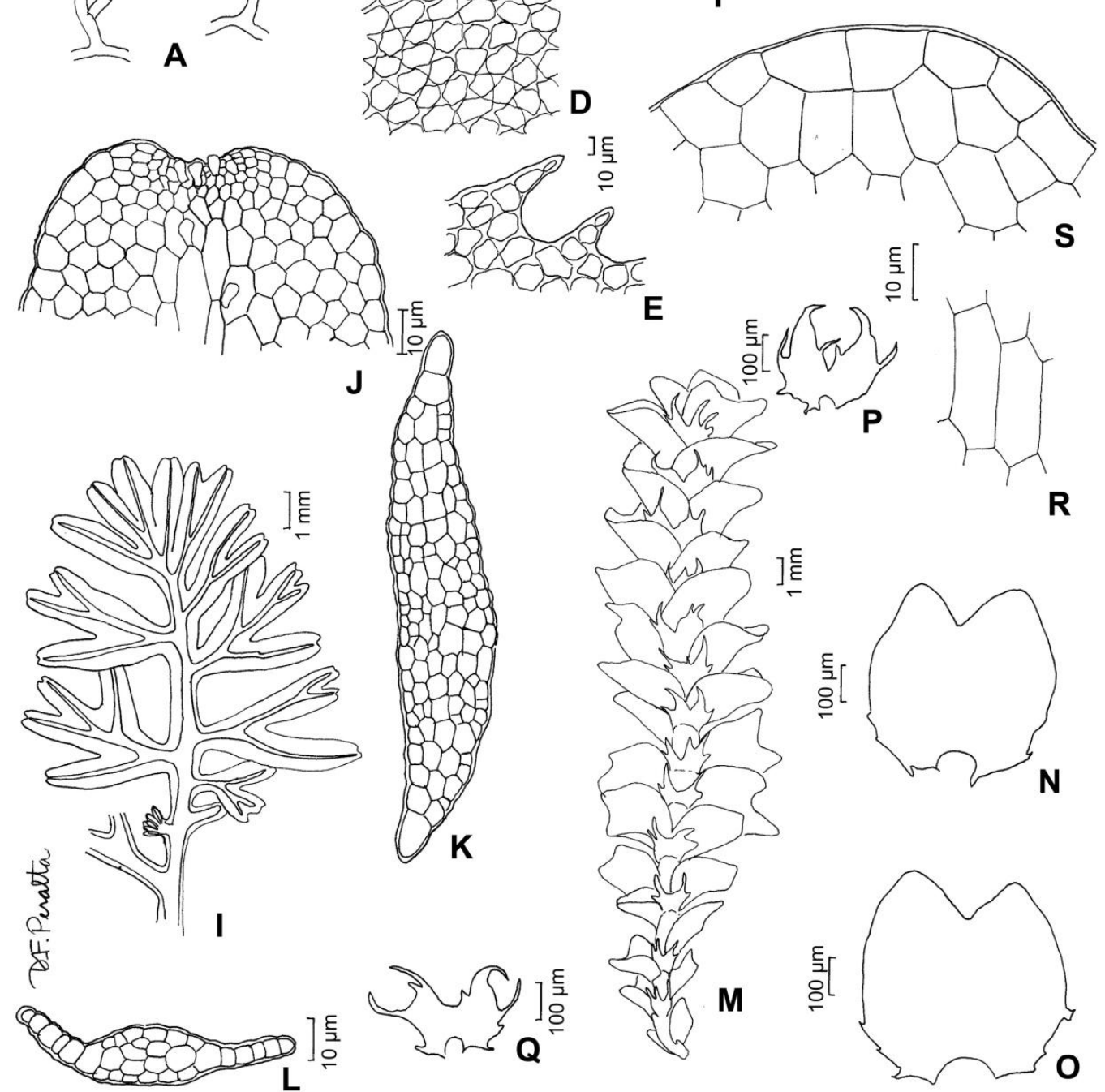

Fig. 37. Adelanthus carabayensis (Mont.) Grolle. A. aspecto do gametófito. B-C. filídios. D. células da lâmina do filídio. E. células da margem do filídio. Riccardia cataractarum (Spruce) K.G. Hell. F. aspecto do gametófito. G. células da lâmina do filídio. H. secção transversal do talo. Riccardia chamedryfolia (With.) Grolle. I. aspecto do gametófito. J. detalhe das células do ápice do talo. K. secção transversal do talo no eixo central. L. secção transversal do talo no ramo. Isotachis inflata Steph. M. aspecto do gametófito. N-O. filídios. P-Q. anfigastros. R. células da lâmina do filídio. S. células da margem do filídio (A-E. Dias Neto 139a p.p.; F-H. O. Yano \& Wanderley 10654; I-L. O. Yano \& Wanderley 10637; M-S. Pirani et al. 10291). 
1.1. Riccardia cataractarum (Spruce) K.G. Hell, Bolm. Univ. São Paulo, Bot. 335(25): 97. 1969.

Fig. 37 F-H

Gametófitos talosos, verde-escuros, ramificações irregulares, células epidérmicas do talo, pinas e pínulas, com paredes finas, isodiamétricas, as do bordo não se destacam, secção transversal do talo 2-4 camadas de células de espessura, rizóides ausentes.

Material examinado: Minas Gerais, Santana do Riacho, Cachoeira Farofa, O. Yano \& Wanderley 10654, 10656 p.p., 10870 p.p. (SP220349; SP220351; SP220563).

Associada a Micropterygium campanense Spruce ex Reimers e Paracromastigum pachyrrhizon (Nees) Fulford. Ocorre nos estados de CE, DF, ES, GO, MG, MS, MT, RJ, RS, SC e SP. Na Serra do Cipó, cresce em rocha. Esta espécie é comumente encontrada próximo a cachoeiras, perto dos respingos ou em áreas encharcadas, é diferenciada pela secção transversal que apresenta uma epiderme de células bem menores que as interiores.

1.2. Riccardia chamedryfolia (With.) Grolle, Trans. Brit. Bryol. Soc. 5: 772. 1969.

Fig. $37 \mathrm{I}-\mathrm{L}$

Gametófitos talosos, verde-claros, ramificação bipinada ou irregular, as pínulas geralmente mais largas no ápice, células epidérmicas do talo das pinas e pínulas com paredes celulares finas, isodiamétricas, as do bordo não se destacam, secção transversal do talo, 5-7 camadas de células de espessura, rizóides ausentes.

Material examinado: Minas Gerais, Conceição do Mato Dentro, Vital 1241 p.p. (SP87129); O. Yano 482 (SP132039); Santana do Riacho, Cachoeira Farofa, O. Yano \& Wanderley 10637, 10639, 10691, 10717 (SP220332;
SP220334; SP220386; SP220412); Câmara 1898 (SP419642).

Associada a Kurzia capillaris (Sw.) Grolle. Ocorre nos estados de AC, AM, BA, DF, ES, GO, MG, MT, RJ, RS, SC e SP. Na Serra do Cipó, cresce em rocha e tronco vivo.

\section{Balantiopsidaceae}

Gametófitos folhosos, avermelhados, marrons, pretos, verde-escuros ou vináceos, hábito ascendente ou ereto, ramificações tipo Frullania ou ventral intercalar. Filídios súcubos, inserção oblíqua, bilobados ou inteiros, margem na região ventral reta, região dorsal plana, sem células diferenciadas. Células retangulares, parede celular uniformemente delgada, cutícula lisa, ou papilosa, trigônios presentes ou ausentes, células da margem iguais as interiores. Ocelos ausentes. Anfigastro bilobado, grandes (ca. 3 a 10x larg. do caulídio), denteado. Rizóides monomórficos, restritos à base dos ramos, incolores. Gametângios terminais, anterídios em eixos especializados com filídios modificados, arquegônios marsúpio ou perigínio, liso. Cápsula alongada.

É uma família amplamente distribuída nas áreas de Floresta Atlântica no Brasil, caracterizada principalmente pela coloração fortemente avermelhada. Ocorre principalmente como terrícola.

Para a identificação das espécies é necessário análise da morfologia do anfigastro e das células da lâmina do filídio. No Brasil ocorrem três gêneros e 11 espécies; na Serra do Cipó ocorrem dois gêneros e quatro espécies.

Bibliografia básica: Gradstein \& Costa (2003); Gradstein et al. (2001).

Chave para os gêneros

1. Gametófitos ascendentes, anfigastros com $1 / 2$ ou mais do compr. do filídio 1. Isotachis

1'. Gametófitos prostrados, anfigastros com 1/10-1/4 do compr. do filídio 2. Neesioscyphus

\section{Isotachis Mitt.}

Gametófitos folhosos, avermelhados, marrons, pretos, verde-escuros ou vináceos, estolões ausentes, hábito ascendente ou ereto, ramificações do tipo ventral intercalar. Filídios súcubos, inserção oblíqua, bilobados, margem inteira, na região ventral reta, margem na região dorsal plana, sem células diferenciadas. Células retangulares, parede celular uniformemente delgada, cutícula lisa, trigônios ausentes, células da margem iguais as interiores. Ocelos ausentes. Anfigastro bilobado, grandes (ca. 3 a 10x larg. do caulídio), denteado, rizóides monomórficos, restritos à base dos ramos, incolores. Gametângios terminais, anterídios em eixos especializados com filídios modificados, arquegônios marsúpio ou perigínio, liso. Cápsula alongada. Reprodução vegetativa desconhecida. 
Flora da Serra do Cipó, Minas Gerais: Briófitas (Anthocerotophyta, Bryophyta e Marchantiophyta)

Chave para as espécies

1. Margem do filídio com células infladas, ápice regularmente bífido

1.1. I. inflata

1'. Margem do filídio sem células infladas, ápice irregularmente bífido 1.2. I. multiceps

1.1. Isotachis inflata Steph., Archos Mus. Nac. Rio de Janeiro 13: 113. 1903.

Fig. $37 \mathrm{M}-\mathrm{S}$

Gametófitos robustos. Filídios imbricados, ovados, conchiformes, cutícula lisa, margem do filídio com dentes na base, anfigastros bífidos, dentes longos nos segmentos.

Material examinado: Minas Gerais, Santana do Riacho, Pirani et al. 10291 (SP386346, SPF).

Ocorre nos estados de DF, ES e RJ. Na Serra do Cipó, cresce em solo.

1.2. Isotachis multiceps (Lindenb. \& Gottsche) Gottsche, Mexik. Leverm.: 105. 1863.

Fig. $38 \mathrm{~A}-\mathrm{F}$

Gametófitos robustos. Filídios imbricados, ovados, conchiformes, cutícula lisa, margem do filídio inteira, anfigastros bífidos com pequenos dentes.

Material examinado: Minas Gerais, Conceição do Mato Dentro, O. Yano 532 (SP132050); Vital 7580
(SP132813); Congonhas do Norte, Serra Talhada, Pirani et al. 5641 p.p. (SP389358, SPF).

Associada a Sematophyllum subdepressum (Hampe) Broth. Ocorre nos estados de ES, RJ, RS e SP. Na Serra do Cipó, cresce em solo e rocha.

\section{Neesioscyphus Grolle}

Gametófitos folhosos, verde-escuros ou vináceos, estolões ausentes, hábito ascendente, ramificações do tipo ventral intercalar. Filídios súcubos, inserção oblíqua, bilobados ou inteiros, margem inteira, na região ventral reta, margem na região dorsal plana, sem células diferenciadas. Células retangulares, parede celular uniformemente delgada, cutícula lisa, trigônios ausentes, células da margem iguais as interiores. Ocelos ausentes. Anfigastro bilobado, grandes (ca. 3 a 10x larg. do caulídio), denteado, rizóides monomórficos, restritos à base dos ramos, incolores. Gametângios terminais, anterídios em eixos especializados com filídios modificados, arquegônios marsúpio ou perigínio, liso. Cápsula alongada. Reprodução vegetativa desconhecida. 


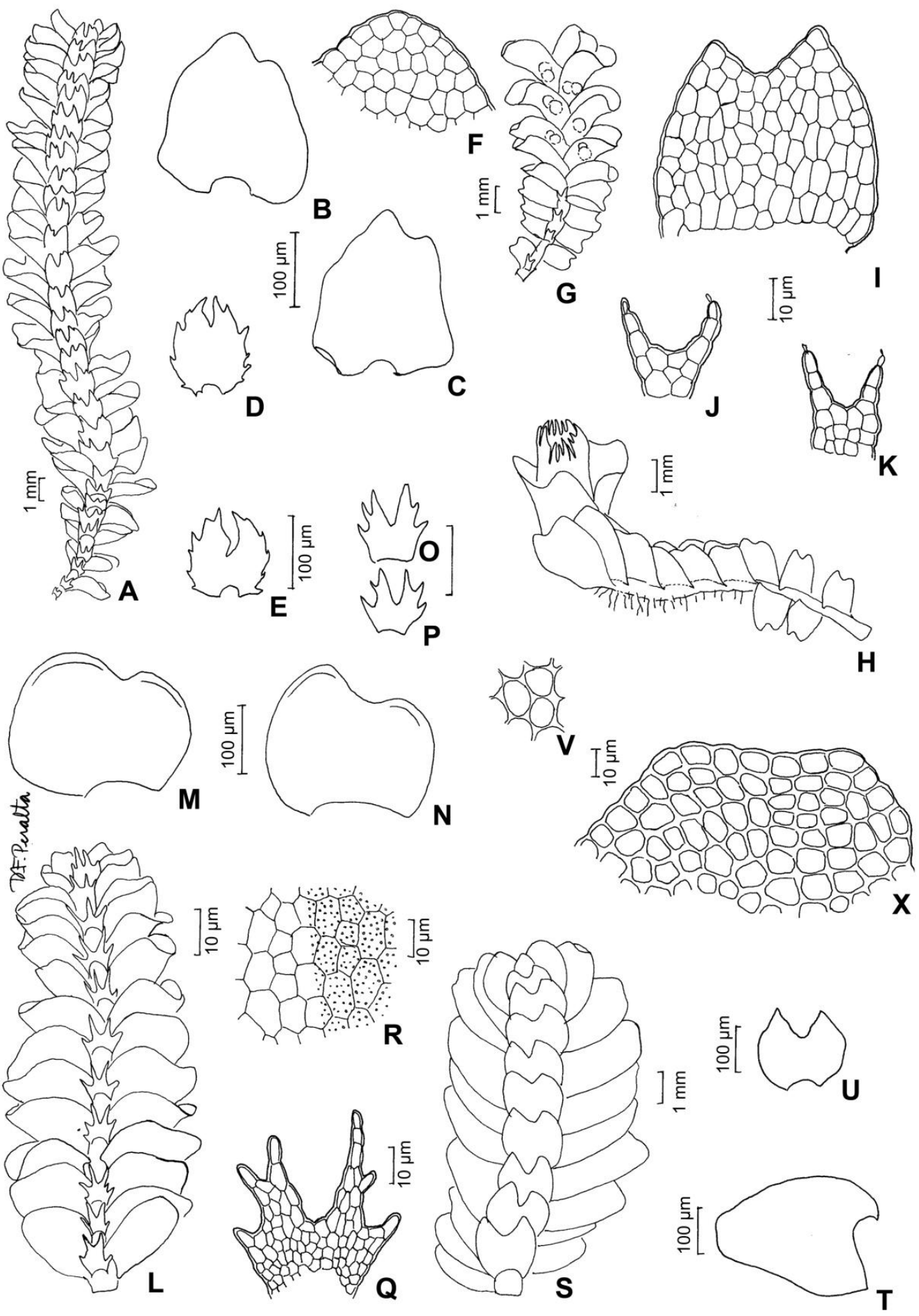

Fig. 38. Isotachis multiceps (Lindenb. \& Gottsche) Gottsche. A. aspecto do gametófito. B-C. filídios. D-E. anfigastros. F. células da margem do filídio. Neesioscyphus argillaceus (Nees) Grolle. G. aspecto do gametófito masculino. H. aspecto do gametófito feminino. I. filídio. J-K. anfigastros. Neesioscyphus homophyllus (Nees) Nees. L. aspecto do gametófito. M-N. filídios. O-P. anfigastros. Q. detalhe do anfigastro. R. células da lâmina do filídio. Calypogeia grandistipula (Steph.) Steph. S. aspecto do gametófito. T. filídio. U. anfigastro. V. células da lâmina do filídio. X. células da margem do filídio (A-F. O. Yano 532; G-K. (Nees) Grolle; L-R. Pirani et al. 10291; S-X. Vital 1250). 
Flora da Serra do Cipó, Minas Gerais: Briófitas (Anthocerotophyta, Bryophyta e Marchantiophyta)

2.1. Neesioscyphus argillaceus (Nees) Grolle, Österr. Bot. Zeitschr. 111(1): 24. 1964.

Fig. $38 \mathrm{G}-\mathrm{K}$

Gametófitos delicados. Filídios imbricados ovalados bífidos, cutícula lisa, margem inteira, anfigastros sem dentes.

Material examinado: Minas Gerais, Conceição do Mato Dentro, Vital 1255 p.p. (SP87133); Santana do Riacho, O. Yano \& Wanderley 10662 (SP220357).

Associada a Neesioscyphus homophilus (Nees) Nees. Ocorre nos estados de DF, ES, GO, MG, MT, RJ, RS e SP. Na Serra do Cipó, cresce em solo e rocha submersa em riacho. $O$ anfigastro desta espécie é caracteristicamente avermelhado, contrastando com a coloração esbranquiçada dos filídios.

2.2. Neesioscyphus homophyllus (Nees) Nees, Österr. Bot. Zeitschr. 111(2-3): 188. 1964.

Fig. $38 \mathrm{~L}-\mathrm{R}$

Gametófitos delicados. Filídios imbricados, ovalados, conchiformes, bífidos, cutícula verrucosa, margem inteira, anfigastros denteados.

Material examinado: Minas Gerais, Conceição do Mato Dentro, Vital 1255 p.p., 7581 p.p. (SP87133, SP136551); Santana do Riacho, Pirani et al. 10291 (SP230721); O. Yano \& Wanderley 10643, 10866 p.p. (SP220338; SP220559).

Associada a Neesioscyphus argillaceus (Nees) Grolle, Sematophyllum cuspidiferum Mitt. e Telaranea nematodes (Gottsche ex Austin) M. Howe. Ocorre nos estados de GO, MG, RJ e SP.

$\mathrm{Na}$ Serra do Cipó, cresce em solo e rocha.

\section{Calypogeiaceae}

É uma família amplamente distribuída no Brasil, caracterizada principalmente pelo hábito prostrado e pela ausência de lóbulos. Ocorre principalmente como terrícola, comumente entre outras briófitas. Para a identificação das espécies é necessário análise da morfologia do anfigastro e das células da lâmina do filídio. No Brasil ocorrem dois gêneros e 19 espécies; na Serra do Cipó ocorre o gênero Calypogeia com três espécies.

Bibliografia básica: Fulford (1963); Gradstein \& Costa (2003); Gradstein et al. (2001).

\section{Calypogeia Raddi}

Gametófitos folhosos, marrons ou verdeclaros ou verde-escuros, estolões ausentes, hábito prostrado, ramificações do tipo ventral intercalar. Filídios íncubos, inserção oblíqua, bilobados ou inteiros, margem na região ventral reta, margem na região dorsal plana, sem células diferenciadas. Células retangulares ou hexagonais, parede celular uniformemente delgada, cutícula lisa ou papilosa, trigônios ausentes, células da margem diferenciadas e formando bordo ou iguais as interiores. Ocelos ausentes. Anfigastro bilobado ou inteiro, pequenos (ca. 1 a $2 x$ larg. do caulídio), crenulado ou denteado, rizóides monomórficos, em tufos na base dos anfigastros, incolores. Gametângios laterais em pequenas ramificações, anterídios em eixos especializados com filídios modificados, arquegônios marsúpio, lateralmente aplainado. Cápsula alongada. Reprodução vegetativa por filídios caducos ou ramos geminíferos.

1. Filídio inteiro, segmentos do anfigastro sem dentes

1'. Filídio com 2 dentes, segmentos do anfigastro com 2 dentes.

2. Dentes do filídio formados por 2 células

1.1. C. grandistipula

2 '. Dentes do filídio formados por 1 célula

1.2. C. laxa

1.3. C. peruviana

1.1. Calypogeia grandistipula (Steph.) Steph. Spec. Hepat. 3: 408. 1908.

Fig. $38 \mathrm{~S}-\mathrm{X}$

Gametófitos robustos. Filídios imbricados, ovados, ápice inteiro, anfigastros conspícuos, sem dentes.

Material examinado: Minas Gerais, Conceição do Mato Dentro, Vital 1250 (SP87131).

Ocorre nos estados de ES, MG, RJ e SP. Na Serra do Cipó, cresce em solo. Esta é a única das espécies deste gênero no Brasil que apresenta os anfigastros imbricados e o hábito robusto.

1.2. Calypogeia laxa Gottsche \& Lindenb. in Gottsche et al., Syn. Hepat.: 713. 1847.

Fig. 39 A-E

Gametófitos delicados. Filídios aplainados, ovados, ápice bífidos, segmentos com 2 células, anfigastros conspícuos, bífidos em sinus largos, dentes dos segmentos estreitos. 
Material examinado: Minas Gerais, Santana do Riacho, O. Yano \& Wanderley 10906 p.p. (SP220599); Pirani et al. 5548 p.p. (SP388846, SPF).

Associada a Campylopus heterostachys (Hampe) A. Jaeger, Symphyogyna podophylla (Thumb.) Mont. \& Nees e Telaranea diacantha (Mont.) J.J. Engel \& G.L. Merrill. Ocorre nos estados de BA, CE, DF, ES, MG, PE, RJ, SC e SP. Na Serra do Cipó, cresce em solo. Esta espécie é comumente encontrada associada a outras briófitas e é caracteristicamente translúcida.

1.3. Calypogeia peruviana Nees \& Mont. in Montagne, Ann. Sci. Nat. Bot. sér. 2, 9: 47. 1838.

Fig. 39 F-J

Gametófitos medianos a robustos. Filídios distante a imbricados, ovados, ápice bífido, segmentos curtos, terminando em 1 célula no ápice, anfigastros conspícuos, bífidos em sinus largos, dentes do segmento largos, truncados.

Material examinado: Minas Gerais, Santana do Riacho, O. Yano \& Wanderley 10829 (SP220522); Dias Neto 189 (SP419802).

Ocorre nos estados de BA, DF, GO, MG, RJ, SC e SP. Na Serra do Cipó, cresce em solo. Esta espécie apresenta o gametófito coloração amarronzado.

\section{Cephaloziaceae}

Gametófitos folhosos, avermelhados, marrons, verde-claros ou vináceos, estolões presentes ou ausentes, hábito ascendente ou prostrado, ramificações tipo Frullania ou ventral intercalar. Filídios súcubos, inserção transversal, bilobados ou inteiros., margem na região ventral reta, região dorsal plana, sem células diferenciadas. Células quadrático irregulares, parede celular uniformemente delgada, cutícula lisa ou papilosa, trigônios ausentes, células da margem iguais as interiores. Ocelos ausentes. Anfigastro ausente ou inteiro e pequenos. Rizóides monomórficos, restritos à base dos ramos, incolores. Gametângios laterais em pequenas ramificações, anterídios em eixos especializados com filídios modificados, arquegônios perianto, liso. Cápsula alongada.

É uma família amplamente distribuída na área de Floresta Atlântica do Brasil, caracterizada principalmente pelo hábito pequeno, prostrado e pela ausência de lóbulos. Ocorre principalmente como terrícola, comumente entre outras briófitas. Para a identificação das espécies é necessário análise da morfologia das células da lâmina do filídio. No Brasil ocorrem cinco gêneros e 11 espécies; na Serra do Cipó ocorrem dois gêneros e duas espécies.

Bibliografia básica: Fulford (1968); Gradstein \& Costa (2003); Gradstein et al. (2001).

Chave para os gêneros

1. Filídios bífidos, sinus em forma de $\mathrm{C}$, parede celular delgada

1. Cephalozia

1 '. Filídios inteiros, parede celular com trigônios

2. Odontoschisma

\section{Cephalozia (Dumort.) Dumort.}

Gametófitos folhosos, avermelhados ou translúcidos, estolões presentes, hábito prostrado, ramificações do tipo ventral intercalar. Filídios súcubos, transversal, bilobados, margem inteira, na região ventral reta, margem na região dorsal plana, sem células diferenciadas. Células quadráticoirregulares, parede celular uniformemente delgada, cutícula lisa, trigônios ausentes, células da margem iguais as interiores. Ocelos ausentes. Anfigastros ausentes. Gametângios laterais em pequenas ramificações, anterídios em eixos especializados com filídios modificados, perianto liso. Cápsula alongada. Reprodução vegetativa por ramos geminíferos.
1.1. Cephalozia crassifolia (Lindenb. \& Gottsche) Fulford, Mem. New York Bot. Gard. 11(3): 312. 1968.

Fig. 39 K-M

Gametófitos delicados, translúcidos. Filídios aplainados, ovados, ápice bífido, sinus em forma de C, células com paredes delgadas, sem anfigastros.

Material examinado: Minas Gerais, Santana do Riacho, Pirani et al. 10332 p.p. (SP386345, SPF); O. Yano \& Wanderley 10856 p.p. (SP220549).

Associada a Leptoscyphus amphibolius Grolle e Telaranea nematodes (Gottsche ex Austin) M. Howe. Ocorre nos estados de BA, ES, GO, RJ, SC e SP. 


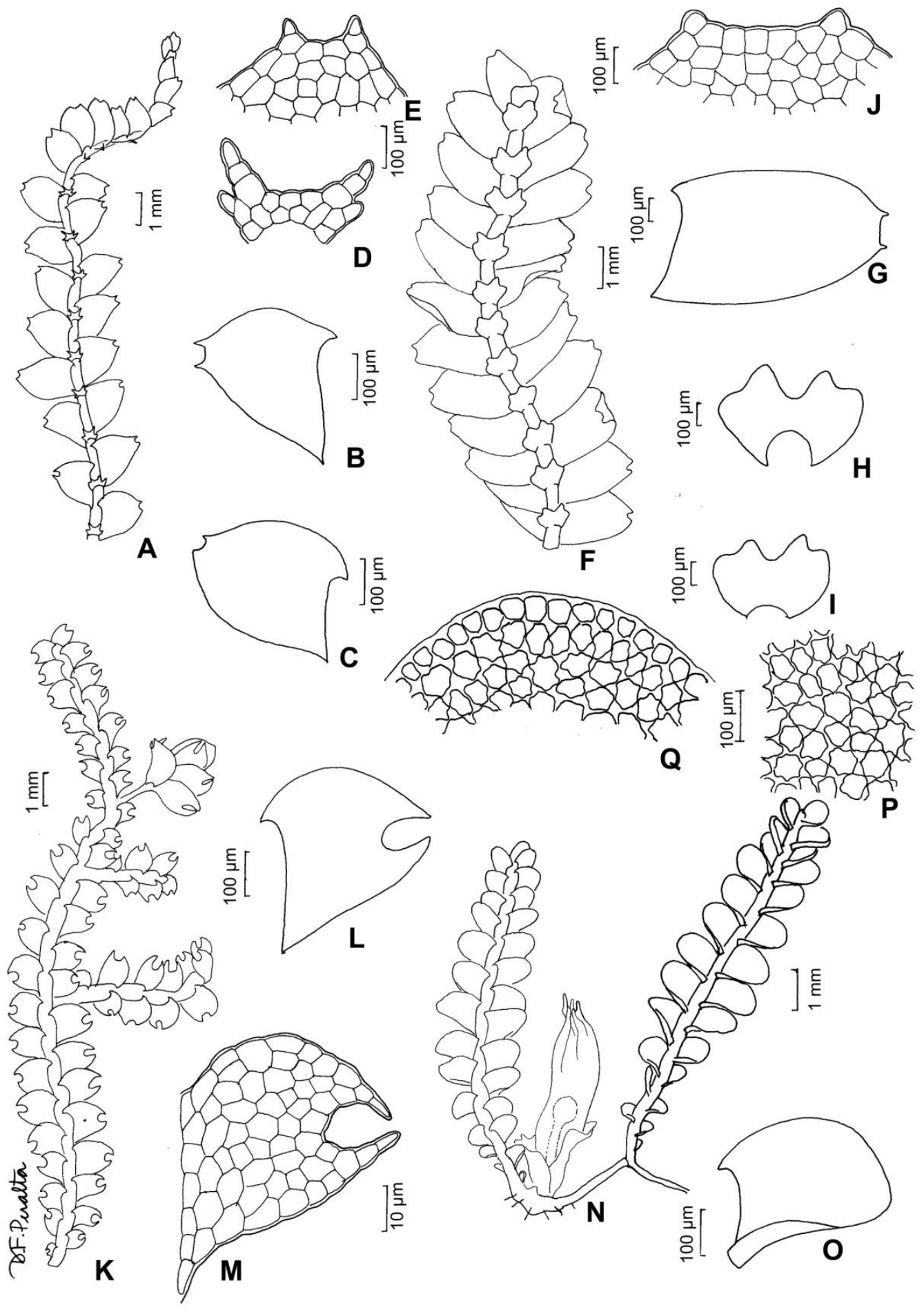

Fig. 39. Calypogeia laxa Gottsche \& Lindenb. A. aspecto do gametófito. B-C. filídios. D-E. anfigastros. Calypogeia peruviana Nees \& Mont. F. aspecto do gametófito. G. filídio. H-I. anfigastros. J. células do ápice margem do filídio. Cephalozia crassifolia (Lindenb. \& Gottsche) Fulford. K. aspecto do gametófito. L-M. filídios. Odontoschisma denudatum (Nees) Dumort. N. aspecto do gametófito com perianto. O. filídio. P. células da lâmina do filídio. Q. células da margem do filídio (A-E. O. Yano \& Wanderley 10906 p.p.; F-J. O. Yano \& Wanderley 10829; K-M. Pirani et al. 10332 p.p.; N-Q. Vital 1222). 
Na Serra do Cipó, cresce em solo. Esta espécie é facilmente identificada pelo disposição dos filídios quase na transversal e pelo sinus em forma de $\mathrm{C}$.

\section{Odontoschisma (Dumort.) Dumort.}

Gametófitos folhosos, avermelhados, verdeclaros ou vináceos, estolões presentes, hábito ascendente ou prostrado, ramificações do tipo ventral intercalar. Filídios súcubos, inserção transversal, inteiros, margem inteira, na região ventral reta, margem na região dorsal plana, sem células diferenciadas. Células quadrático-irregulares, parede celular uniformemente delgada, cutícula lisa, trigônios grandes, células da margem iguais as interiores ou diferenciadas. Ocelos ausentes. Anfigastro inteiro, pequenos (ca. 1 a $2 x$ larg. do caulídio), inteiro, rizóides monomórficos, restritos à base dos ramos, incolores. Gametângios laterais em pequenas ramificações, anterídios em eixos especializados com filídios modificados, perianto liso. Cápsula alongada. Reprodução vegetativa por ramos geminíferos.

2.1. Odontoschisma denudatum (Nees) Dumort., Recueil d'Observ. Jungerm.: 19. 1835.

Fig. $39 \mathrm{~N}-\mathrm{P}$

Gametófitos delicados, marrons ou vermelhos. Filídios imbricados, ovados, ápice inteiro, células com paredes espessadas formando trigônios, sem anfigastro.

Material examinado: Minas Gerais, Conceição do Mato Dentro, Vital 1222 (SP87122); O. Yano 515, 516 p.p. (SP132049; SP135474); Câmara et al. 2098 (SP419710); Dias Neto 75 (SP419726); Dias Neto 167 (SP419786).
Associada a Campylopus fragilis (Brid.) Bruch \& Schimp. ssp. fragiliformis (J.-P. Frahm) J.-P. Frahm. Ocorre nos estados de AM, BA, GO, MT, PE, RJ, SC e SP. Na Serra do Cipó, cresce em solo e tronco vivo. Esta espécie é facilmente identificada pelos filídios imbricados quando secos, pela coloração verde-claro e os grandes trigônios das células do filídio.

\section{Cephaloziellaceae}

Gametófitos folhosos, verde-claros, estolões presentes, hábito ascendente ou prostrado, ramificações tipo Frullania, ventral intercalar ou lateral intercalar. Filídios súcubos, inserção transversal, bilobados ou inteiros, margem na região ventral reta, região dorsal plana, sem células diferenciadas. Células quadrático irregulares, parede celular uniformemente delgada, cutícula lisa, trigônios ausentes, células da margem iguais as interiores. Ocelos ausentes. Anfigastro ausente ou muito pequeno e inteiro, rizóides monomórficos, incolores. Gametângios laterais em pequenas ramificações, anterídios em eixos especializados com filídios modificados, arquegônios perianto, liso. Cápsula alongada.

É uma família amplamente distribuída no Brasil, caracterizada principalmente pelo hábito delicado e pela ausência de lóbulos. Ocorre principalmente como terrícola e corticícola, comumente entre outras briófitas. Para a identificação das espécies é necessário análise da morfologia das células da lâmina do filídio. No Brasil ocorrem quatro gêneros e 10 espécies; na Serra do Cipó ocorrem dois gêneros e duas espécies.

Bibliografia básica: Gradstein \& Costa (2003); Gradstein et al. (2001).

\section{Chave para os gêneros}

1. Filídios distintamente súcubos, paredes das células dos filídios delgada

1. Cephaloziella

1 '. Filídios transversalmente inseridos, paredes das células dos filídios espessas

2. Cylindrocolea

\section{Cephaloziella (Spruce) Schiffn.}

Gametófitos folhosos, verde-claros, estolões
presentes, hábito ascendente ou prostrado,
ramificações do tipo ventral intercalar ou lateral
intercalar. Filídios súcubos, inserção transversal,
bilobados, margem na região ventral reta, margem na
região dorsal plana, sem células diferenciadas.
Células quadrático-irregulares, parede celular
uniformemente delgada, cutícula lisa, trigônios
ausentes, células da margem iguais as interiores.
Ocelos ausentes. Anfigastro ausente ou muito
pequeno (ca. 1/3 a $1 / 2 x$ larg. do caulídio), inteiro,
rizóides monomórficos, ao longo de toda a porção
ventral, incolores. Gametângios laterais em pequenas ramificações, anterídios em eixos especializados com filídios modificados, perianto liso. Cápsula alongada. Reprodução vegetativa por gemas na margem dos filídios.

1.1. Cephaloziella granatensis (Jack) Fulford, Mem. New York Bot. Gard. 11(4): 411. 1976.

Fig. $40 \mathrm{~A}-\mathrm{E}$

Gametófitos verde-brilhantes. Caulídio irregularmente ramificados. Filídios patentes, perpendicularmente inseridos, bífidos, células irregulares, parede celular delgada, sem trigônios, anfigastro ausente. 
Flora da Serra do Cipó, Minas Gerais: Briófitas (Anthocerotophyta, Bryophyta e Marchantiophyta)

Material examinado: Minas Gerais, Santana do Riacho, O. Yano \& Wanderley 10793 p.p. (SP220486).

Associada a Fissidens pallidinervis Mitt. Ocorre nos estados de MG (Caldas, Rio Verde) e RJ (Teresópolis, Serra dos Órgãos). Na Serra do Cipó, cresce em termiteiro.

\section{Cylindrocolea R.M. Schust.}

Gametófitos folhosos, verde-claros, estolões presentes, hábito ascendente ou prostrado, ramificações do tipo ventral intercalar ou lateral intercalar. Filídios súcubos, inserção oblíqua, bilobados, margem inteira, na região ventral reta, margem na região dorsal plana, sem células diferenciadas. Células quadrático-irregulares, parede celular uniformemente delgada, cutícula lisa, trigônios ausentes, células da margem iguais as interiores. Ocelos ausentes. Anfigastro ausente ou muito pequeno (ca. 1/3 a 1/2x larg. do caulídio), inteiro, rizóides monomórficos, ao longo de toda a porção ventral, incolores. Gametângios laterais em pequenas ramificações, anterídios em eixos especializados com filídios modificados, perianto liso. Cápsula alongada. Reprodução vegetativa por gemas na margem dos filídios.

2.1. Cylindrocolea rhizantha (Mont.) R.M. Schust., Nova Hedwigia 22: 175. 1971.

Fig. 40 F-J

Gametófitos verde-brilhantes, caulídio irregularmente ramificado. Filídios aplainados, obliquamente inseridos, súcubos, bífidos, células irregulares; parede celular delgada, sem trigônios, anfigastro ausente.

Material examinado: Minas Gerais, Conceição do Mato Dentro, Vital 1211 (SP87115).

Ocorre nos estados de AC, AL, BA, DF, ES, GO, MG, PE, RJ e SP. Na Serra do Cipó, cresce em solo.

\section{Chonecoleaceae}

É uma família amplamente distribuída no Brasil, caracterizada principalmente pelo hábito delicado e pela ausência de lóbulos. Ocorre principalmente como corticícola. No Brasil ocorre somente o gênero Chonecolea com uma espécie.

Bibliografia básica: Gradstein \& Costa (2003); Gradstein et al. (2001).

\section{Chonecolea Grolle}

Gametófitos folhosos, verde-escuros a quase pretos, estolões ausentes, hábito prostrado, ramificações lateral intercalar. Filídios súcubos, inserção transversal, bilobados, margem inteira, na região ventral reta, margem na região dorsal plana, sem células diferenciadas. Células quadráticoirregulares, parede celular uniformemente delgada, cutícula lisa, trigônios ausentes, células da margem iguais as interiores. Ocelos ausentes. Anfigastro inteiro, muito pequeno (ca. $1 / 3$ a $1 / 2 x$ larg. do caulídio), inteiro, rizóides monomórficos, ao longo de toda a porção ventral, incolores. Gametângios terminais, anterídios em eixos especializados com filídios modificados, perianto plicado. Cápsula esférica. Reprodução vegetativa por periantos caducos.

1.1. Chonecolea doellingeri (Nees) Grolle, Revue Bryol. Lichénol. 25: 295. 1956.

Fig. $40 \mathrm{~K}-\mathrm{N}$

Gametófitos folhosos, verde-escuros. Filídios súcubos, inserção transversal, bilobados, inteira. Células quadrático-irregulares, parede celular delgada, cutícula lisa, trigônios ausentes, células da margem iguais as interiores. Anfigastro inteiro, muito pequeno (ca. 1/3 a 1/2x larg. do caulídio). Gametângios terminais, anterídios em eixos especializados com filídios modificados, perianto plicado. Cápsula esférica.

Material examinado: Minas Gerais, Santana do Riacho, Câmara 1948 (SP419661).

Ocorre nos estados do DF, ES, MG, MS, PR, RJ, RS, SC e SP. Na Serra do Cipó, cresce em rocha. Esta espécie é comumente corticícola e encontrada na margem de trilhas e áreas abertas.

\section{Fossombroniaceae}

É uma família amplamente distribuída no Brasil, caracterizada principalmente pelo hábito prostrado e aspecto de alface. Ocorre principalmente como terrícola. Para a identificação das espécies é necessário análise da morfologia dos esporos. No Brasil ocorre apenas o gênero Fossombronia com três espécies.

Bibliografia básica: Gradstein \& Costa (2003); Gradstein et al. (2001); Yano \& Peralta (2008). 

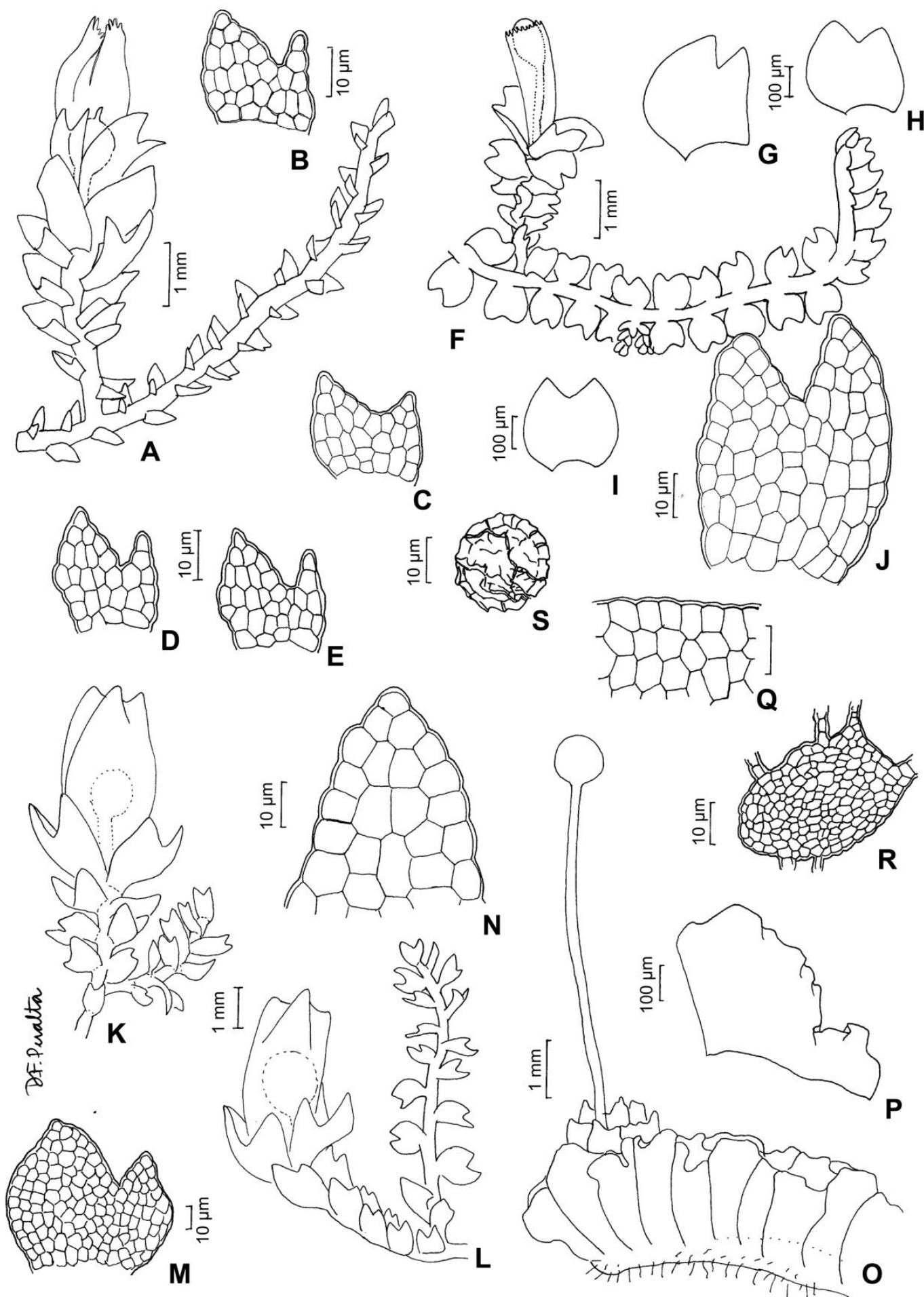

Fig. 40. Cephaloziella granatensis (Jack) Fulford. A. aspecto do gametófito. B-E. filídios. Cylindrocolea rhizantha (Mont.) R.M. Schust. F. aspecto do gametófito. G-I. filídios. J. detalhe do filídio. Chonecolea doellingeri (Nees) Grolle. K-L. aspecto do gametófito. M. filídio. N. células do ápice do filídio. Fossombronia porphyrorhiza (Nees) Prosk. O. aspecto do gametófito. P. filídio. Q. células da margem do filídio. R. secção transversal do caulídio. S. esporo (A-E. O. Yano \& Wanderley 10793 p.p.; F-J. Vital 1211; K-N. Câmara 1948; O-S. Vital 1213). 
Flora da Serra do Cipó, Minas Gerais: Briófitas (Anthocerotophyta, Bryophyta e Marchantiophyta)

\section{Fossombronia Raddi}

Gametófitos folhosos, verde-claros, estolões ausentes, hábito prostrado, pouco ou não ramificados. Filídios súcubos, inserção longitudinal, bilobados, margem inteira, na região ventral decurrente, margem na região dorsal plana, sem células diferenciadas. Células retangulares, parede celular uniformemente delgada, cutícula lisa, trigônios ausentes, células da margem iguais as interiores. Ocelos ausentes. Anfigastro ausente, rizóides monomórficos, ao longo de toda a porção ventral, avermelhados. Gametângios ventrais no caulídio, abaixo dos filídios, anterídios superfície do talo, arquegônios em pseudoperianto, plicado. Cápsula esférica. Reprodução vegetativa por tubérculos.

1.1. Fossombronia porphyrorhiza (Nees) Prosk., Bryologist 58(3): 197. 1955.

Fig. $40 \mathrm{O}-\mathrm{S}$

Gametófitos folhosos, verde-claros, hábito prostrado. Filídios súcubos, inserção longitudinal, bilobados, margem inteira, sem células diferenciadas. Células retangulares, parede celular uniformemente delgada, cutícula lisa, trigônios ausentes, células da margem iguais as interiores. Anfigastro ausente, rizóides avermelhados. Gametângios ventrais no caulídio, abaixo dos filídios, anterídios superfície do talo, arquegônios em pseudoperianto, plicado. Cápsula esférica.

Material examinado: Minas Gerais, Conceição do Mato Dentro, Vital 1213, 1259, 7589 p.p. (SP87116; SP87134; SP132816); Santana do Riacho, O. Yano \& Wanderley 10871 (SP220564); Dias Neto 137 (SP419767).
Associada a Phaeoceros laevis (L.) Prosk. Ocorre nos estados de BA, CE, DF, ES, GO, MG, MS, MT, PE, RJ, RS, SP e TO. Na Serra do Cipó, cresce em solo. Os rizóides desta espécie são caracteristicamente roxos, e o gametófito cresce em agrupamentos com aspecto de alface.

\section{Geocalycaceae}

Gametófitos folhosos, avermelhados, marrons ou verde-claros, estolões ausentes, hábito ascendente ou prostrado, ramificações tipo Frullania, ventral intercalar ou lateral intercalar. Filídios súcubos, inserção longitudinal, bilobados ou inteiros, margem inteira ou denteada, na região ventral reta, na região dorsal plana, sem células diferenciadas. Células retangulares ou quadrático irregulares, parede celular uniformemente delgada, cutícula lisa, trigônios presentes ou ausentes, células da margem iguais as interiores. Ocelos ausentes. Anfigastro bilobado, grandes (ca. 3 a 10x larg. do caulídio), denteado. Rizóides monomórficos, em tufos na base dos anfigastros, incolores. Gametângios terminais, anterídios em eixos especializados com filídios modificados, arquegônios marsúpio ou perianto, lateralmente aplainado. Cápsula alongada.

É uma família amplamente distribuída no Brasil, caracterizada principalmente pelo hábito prostrado, presença de anfigastro e pela ausência de lóbulos. Ocorre principalmente como terrícola e saxícola. Para a identificação das espécies é necessário análise da morfologia do anfigastro e dos filídios. No Brasil ocorrem seis gêneros e 43 espécies; na Serra do Cipó ocorrem dois gêneros e quatro espécies.

Bibliografia básica: Gradstein \& Costa (2003); Gradstein et al. (2001); Yano \& Peralta (2008).

Chave para os gêneros

1. Células marginais do filídio diferenciadas (maiores), paredes celulares com trigônios

1. Leptoscyphus

1'. Células marginais do filídio não diferenciadas, parede celular sem trigônios

2. Lophocolea

\section{Leptoscyphus Schiffn.}

Gametófitos folhosos, avermelhados ou marrons ou verde-claros, estolões ausentes, hábito prostrado, ramificações do tipo ventral intercalar ou lateral intercalar. Filídios súcubos, inserção longitudinal, inteiros, margem na região ventral reta, margem na região dorsal plana, sem células diferenciadas. Células retangulares, quadráticas ou irregulares, parede celular uniformemente delgada, cutícula lisa, trigônios presentes, células da margem maiores que as interiores. Ocelos ausentes. Anfigastro bilobado, grandes (ca. 3 a 10x larg. do caulídio), denteado, rizóides monomórficos, em tufos na base dos anfigastros, incolores. Gametângios terminais, anterídios em eixos especializados com filídios modificados, perianto lateralmente aplainado. Cápsula alongada. Reprodução vegetativa por filídios caducos ou ramos geminíferos.

1.1. Leptoscyphus amphibolius (Nees) Grolle, Nova Acta Leop. 25(161): 54. 1962.

Fig. $41 \mathrm{~A}-\mathrm{E}$

Gametófitos delicados. Filídios aplainados, inteiros, células marginais diferenciadas, células da lâmina com trigônios, anfigastro bífido, com 2-3 dentes nos segmentos. 

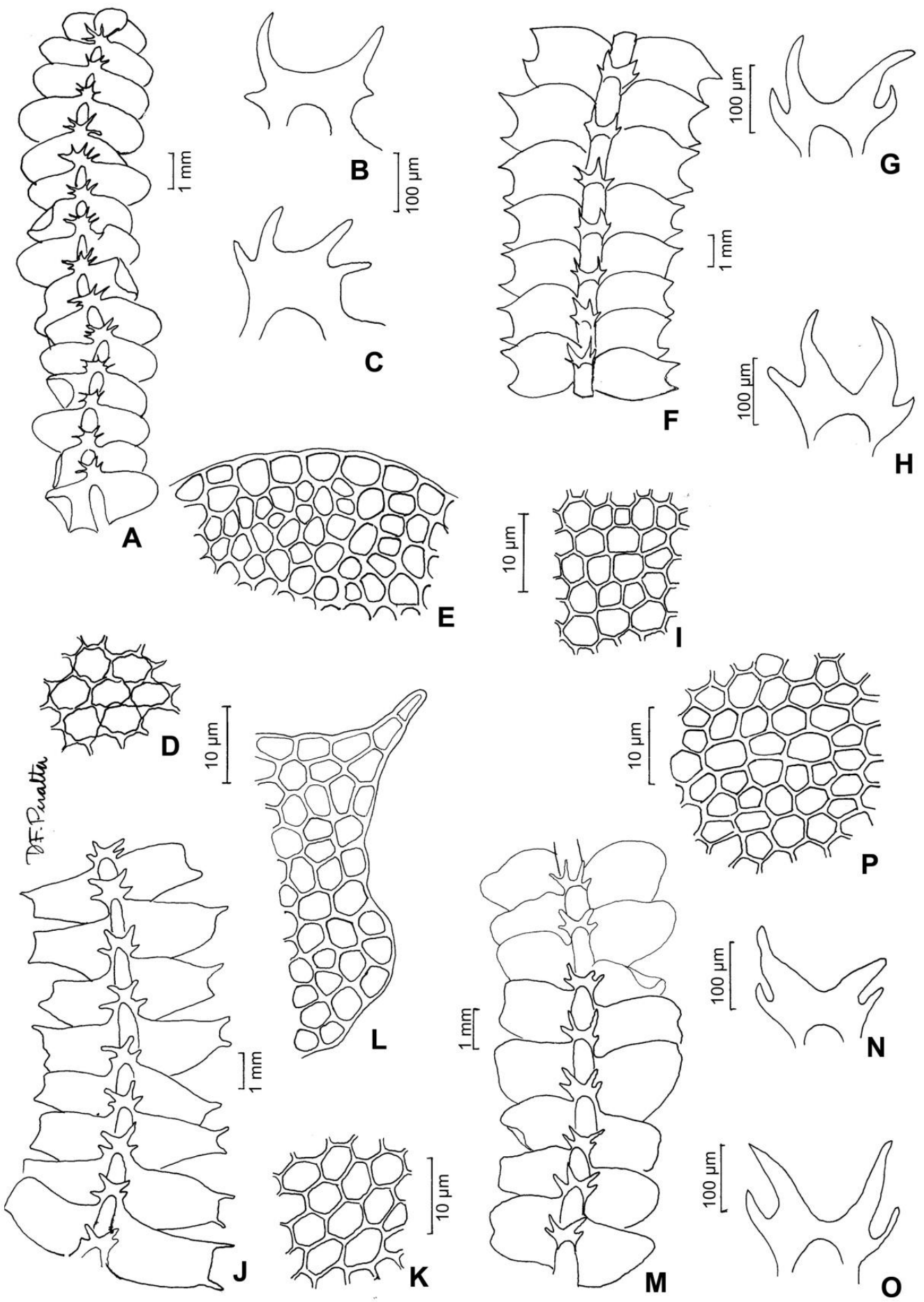

Fig. 41. Leptoscyphus amphibolius (Nees) Grolle. A. aspecto do gametófito. B-C. anfigastros. D. células da lâmina do filídio. E. células da margem do filídio. Lophocolea mandonii Steph. F. aspecto do gametófito. G-H. anfigastros. I. células da lâmina do filídio. Lophocolea martiana Nees. J. aspecto do gametófito. K. células da lâmina do filídio. L. células da margem do filídio. Lophocolea platensis C. Massal. M. aspecto do gametófito. N-O. anfigastros. P. células da lâmina do filídio (A-E. Dias Neto 123; F-I. Oliveira Filho 2; J-L. Vital 1223; M-P. O. Yano \& Wanderley 10811). 
Flora da Serra do Cipó, Minas Gerais: Briófitas (Anthocerotophyta, Bryophyta e Marchantiophyta)

Material examinado: Minas Gerais, Santana do Riacho, O. Yano \& Wanderley 10856 p.p. (SP220549); Dias Neto 123 (SP419757).

Associada a Cephalozia crassifolia Fulford. Ocorre nos estados de ES, GO, MG, RJ e SP. Na Serra do Cipó, cresce em solo. A presença de trigônios nas paredes das células é decisivo na diferenciação desta espécie.

\section{Lophocolea (Dumort.) Dumort.}

Gametófitos folhosos, marrons ou verde-claros, estolões ausentes, hábito prostrado, ramificações do tipo ventral intercalar ou lateral intercalar. Filídios súcubos, inserção longitudinal, bilobados ou inteiros, inteira ou denteada, margem na região ventral reta, margem na região dorsal plana, sem células diferenciadas. Células retangulares, quadráticas ou irregulares, parede celular uniformemente delgada, cutícula lisa ou rugosa, trigônios presentes ou ausentes, células da margem iguais as interiores. Ocelos ausentes. Anfigastro bilobado, grandes (ca. 3 a 10x larg. do caulídio), denteado, rizóides monomórficos, em tufos na base dos anfigastros, incolores. Gametângios terminais, anterídios em eixos especializados com filídios modificados, perianto lateralmente aplainado. Cápsula alongada. Reprodução vegetativa por filídios caducos ou ramos geminíferos.

1. Filídio inteiro, cutícula rugosa

2.3. L. platensis

1'. Filídio bífido, cutícula lisa.

2. Filídio trapezoidal, anfigastro com sinus amplo

2 '. Filídio oblongo, anfigastro com sinus agudo 2.1. L. mandonii

2.1. Lophocolea mandonii Steph., Bull. Herb. Boissier. ser. 2, 7:61. 1907.

Fig. $41 \mathrm{~F}-\mathrm{I}$

Gametófitos delicados. Filídios aplainados, oblongos, bífidos, células da lâmina com paredes delgadas, cutícula rugosa, anfigastro bífido, com sinus amplo.

Material examinado: Minas Gerais, Conceição do Mato Dentro, Oliveira Filho 2 (SP88470); Dias Neto 108 (SP419745).

Ocorre nos estados de BA, ES, GO, MG e RJ. $\mathrm{Na}$ Serra do Cipó, cresce em solo. Os filídios desta espécie apresentam a região distal e proximal caracteristicamente côncavas.

2.2. Lophocolea martiana Nees in Gottsche et al., Syn. Hepat.: 152. 1845.

Fig. $41 \mathrm{~J}-\mathrm{L}$

Gametófitos delicados a robustos. Filídios aplainados, trapezoidais, bífidos, células da lâmina com paredes delgadas, cutícula lisa, anfigastro bífido, sinus amplo.

Material examinado: Minas Gerais, Conceição do Mato Dentro, Vital 1223 (SP87123); Santana do Riacho, O. Yano \& Wanderley 10653 (SP220348).

Ocorre nos estados de AL, AM, AP, BA, CE, ES, GO, MG, MT, PA, PE, PR, RJ, RS, SC, SE e SP. $\mathrm{Na}$ Serra do Cipó, cresce em solo e rocha. Esta espécie apresenta o hábito mais robusto entre as espécies deste gênero e a região entre os dentes marginais são quase paralelos ao caulídio.

2.3. Lophocolea platensis C. Massal., Atti Acad. Sci. Med. Nat. Ferrara 80(3-4): 12. 1906.

Fig. $41 \mathrm{M}-\mathrm{P}$

Gametófitos delicados. Filídios aplainados, oblongos, inteiros, células da lâmina com paredes delgadas, cutícula rugosa, anfigastro bífido, sinus amplo.

Material examinado: Santana do Riacho, Serra da Bandeirinha, O. Yano \& Wanderley 10811, 10819, 10837 (SP220504; SP220512; SP220530); O. Yano \& Wanderley 10767 (SP220461); O. Yano \& Wanderley 10904 (SP220597); Dias Neto 117 (SP419752).

Ocorre nos estados de BA, ES, GO, MG, MT, RS, SC e SP. Na Serra do Cipó, cresce em solo, tronco caído e vivo. É a única espécie deste gênero que possui a margem inteira, diferencia-se de Leptoscyphus pelo anfigastro que apresenta sinus em $\mathrm{V}$ e dois dentes laterais, em Leptoscyphus este anfigastro não possui sinus e apresenta muitos dentes.

\section{Herbertaceae}

É uma família amplamente distribuída no Brasil, caracterizada principalmente pelo hábito ascendente e - filídio bilobulado. Ocorre principalmente como corticícola e rupícola, comumente em áreas 
preservadas e de planalto. Para a identificação das espécies é necessário análise da morfologia das células da lâmina do filídio. No Brasil ocorrem dois gêneros e oito espécies; na Serra do Cipó ocorre o gênero Herbertus e duas espécies.

Bibliografia básica: Gradstein \& Costa (2003); Gradstein et al. (2001).

\section{Herbertus A. Gray}

Gametófitos folhosos, avermelhados ou marrons ou verde-escuros, hábito pendentes, ascendentes ou eretos, pouco ou não ramificados, estolões ausentes. Filídios íncubos, inserção transversal, bilobados, margem inteira, na região ventral reta, margem na região dorsal plana, com células diferenciadas formando vita. Células retangulares, quadráticas ou irregulares, parede celular uniformemente espessada, cutícula lisa, trigônios presentes, células da margem iguais as interiores. Ocelos ausentes. Anfigastro bilobado, grandes (ca. 3 a 10x larg. do caulídio), inteiro, rizóides monomórficos, restritos à base dos ramos, incolores. Gametângios terminais, anterídios em eixos especializados com filídios modificados, perianto plicado. Cápsula esférica. Reprodução vegetativa desconhecida.
1.1. Herbertus bivittatus Spruce, Trans. \& Proc. Bot. Soc. Edinburgh 15: 343. 1885.

Fig. 42 A-N

Gametófitos marrons ou verde-escuros, pouco ou não ramificados, ascendentes ou eretos. Filídios íncubos, inserção transversal, bilobados, mais longos que largos, inteiros, margem na região ventral reta, margem na região dorsal plana, vita larga, bifurcação baixa, próximo a base do filídio. Células retangulares, quadráticas ou irregulares, parede celular uniformemente espessada, cutícula lisa, trigônios presentes. Anfigastro bilobado ou trilobado, grandes (ca. 3 a 10x larg. do caulídio), inteiro.

Material examinado: Minas Gerais, Santana do Riacho, Câmara 1947 p.p., 1958 (SP419660; SP419670); Dias Neto 196 (SP419807).

Associada a Schlotheimia jamesonii (W. Arnott) Brid. Ocorre nos estados do AM, BA, ES, MG, PR, RJ, $R R$, RS e SP. Na Serra do Cipó, cresce em rocha.

1.2. Herbertus serratus Spruce, Mem. Torrey Bot. Club 1: 128. 1890.

Fig. $42 \mathrm{O}-\mathrm{U}$

Gametófitos marrons ou verde-escuros, pouco ou não ramificados, ascendentes ou eretos. Filídios íncubos, inserção transversal, bilobados, mais largos que longos, inteiros, margem na região ventral reta, margem na região dorsal plana, vita larga, bifurcação alta, próximo ao sinus. Células retangulares, quadráticas ou irregulares, parede celular uniformemente espessada, cutícula lisa, trigônios presentes. Anfigastro bilobado ou trilobado, grandes (ca. 3 a 10x larg. do caulídio), inteiro.
Material examinado: Minas Gerais, Santana do Riacho, Dias Neto 201 (SP419809).

Ocorre nos estados de MG, RJ, RS, SC e SP. Na Serra do Cipó, cresce em rocha.

\section{Jubulaceae}

É uma família amplamente distribuída no Brasil, caracterizada principalmente pela coloração verdeoliva a vermelho-vináceo e pelos de lóbulos paralelos ao caulídio. Ocorre principalmente como corticícola. Para a identificação das espécies é necessário análise da morfologia do lóbulo. No Brasil ocorre o gênero Frullania e 60 espécies; na Serra do Cipó ocorrem oito espécies.

Bibliografia básica: Gradstein \& Costa (2003); Gradstein et al. (2001); Stotler (1970); Yano \& Peralta (2008); Yuzawa \& Koike (1989).

\section{Frullania Raddi}

Gametófitos folhosos, avermelhados, marrons ou verde-escuros, estolões ausentes, hábito pendente, ascendente ou prostrado, ramificações tipo Frullania ou lateral intercalar. Filídios íncubos, inserção oblíqua, inteiros, margem inteira, na região ventral lobulada, lóbulo paralelo ao caulídio, margem na região dorsal plana, sem células diferenciadas. Células hexagonais, parede celular uniformemente espessada, cutícula lisa, trigônios presentes, células da margem iguais as interiores. Ocelos ausentes. Anfigastro bilobado, grande (ca. 3 a 10x larg. do caulídio), denteado ou inteiro, rizóides monomórficos, em tufos na base dos anfigastros, incolores. Gametângios laterais em pequenas ramificações, anterídios em eixos especializados com filídios modificados, perianto liso ou quilhado ou rugoso. Cápsula esférica. Reprodução vegetativa por filídios caducos. 
Flora da Serra do Cipó, Minas Gerais: Briófitas (Anthocerotophyta, Bryophyta e Marchantiophyta)

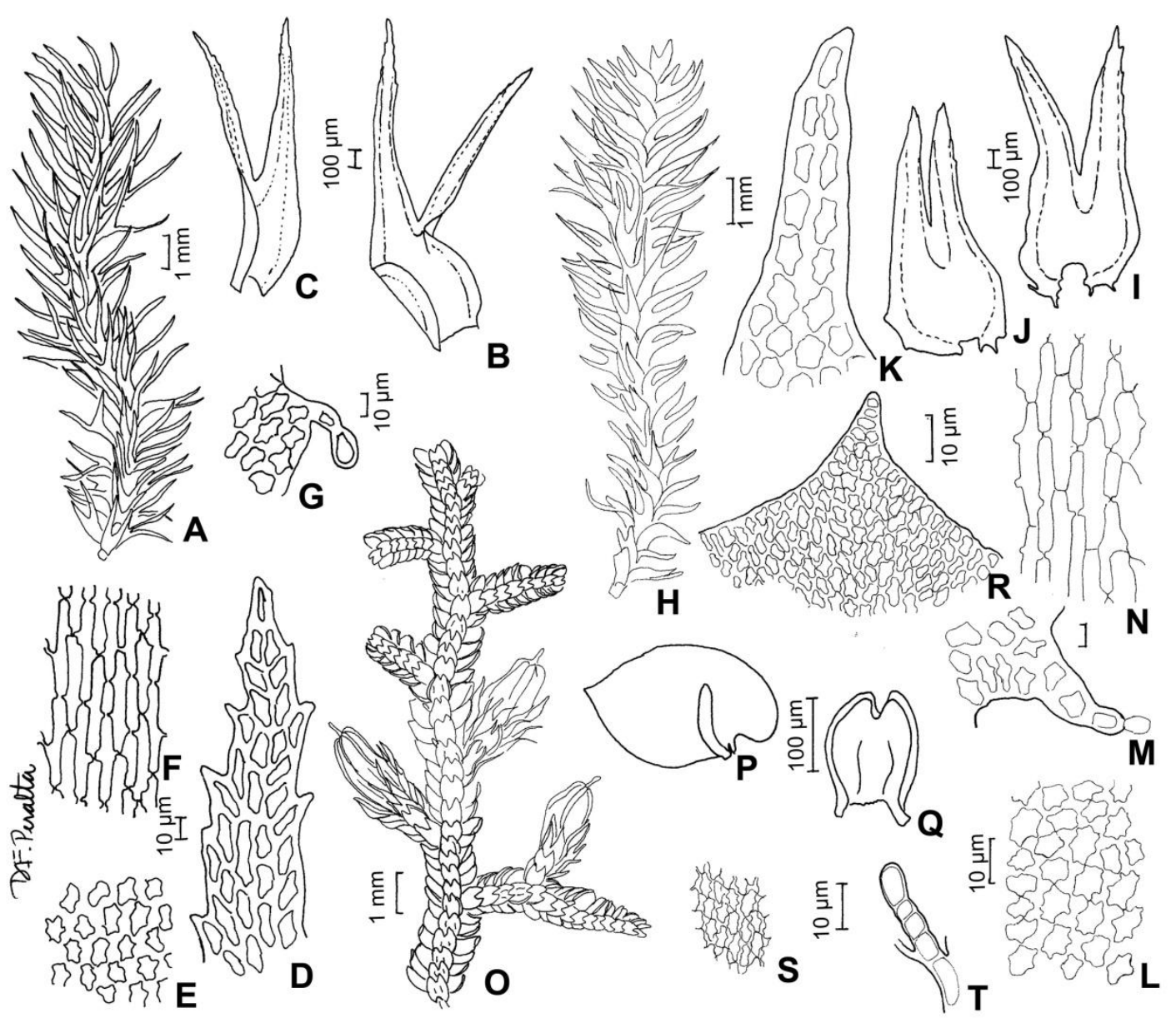

Fig. 42. Herbertus bivittatus Spruce. A. aspecto do gametófito. B-C. filídios. D. ápice do filídio. E. células da lâmina do filídio. F. células da vita. G. células da base do filídio. Herbertus serratus Spruce. H. aspecto do gametófito. I-J. filídios. K. ápice do filídio. L. células da lâmina do filídio. M. células da base do filídio. N. células da vita. Frullania atrata (Sw.) Dumort. O. aspecto do gametófito. P. filídio. Q. anfigastro. R. ápice do filídio. S. células da lâmina do filídio. T. estilete (A-G. Câmara 1947 p.p.; H-N. Dias Neto 201; O-T. Vital 1217).

1. Gametófitos ascendentes, aderidos ao substrato na base.

2. Ápice dos filídios plano, perianto oblongo aplainado 1.1. F. beyrichiana

2'. Ápice dos filídios recurvado, perianto longo-cilíndrico ou quilhado.

3. Perianto inflado, cilíndrico, filídios periqueciais pouco diferenciados

1.3. F. brasiliensis

3'. Perianto não inflado, quilhado, filídios periqueciais longos e estreitos

1'. Gametófitos prostrados.

4. Lóbulo longo-cilíndrico.

5. Lóbulos convergentes em direção ao caulídio

1.8. F. neesii

5'. Lóbulos divergentes em direção ao caulídio

1.4. F. caulisequa

4'. Lóbulo em meia-lua.

6. Anfigastro com sinus pequeno, $1 / 8$ a $1 / 5$ compr. do filídio, lóbulo normalmente incompleto

6'. Anfigastro com sinus mediano $1 / 3$ a $1 / 2$ compr. do filídio, lóbulo normalmente completo.

7. Perianto rugoso, lóbulo com prega paralela ao caulídio.

1.7. F. glomerata

7'. Perianto liso ou com algumas rugas, lóbulo com prega perpendicular ao caulídio 
1.1. Frullania atrata (Sw.) Dumort., Recueil d'Obs. Jungerm. Tournay: 13. 1835.

Fig. $42 \mathrm{~V}-\mathrm{A} 1$

Gametófitos medianos, ascendentes ou pêndulos, ramificações pinadas, lobos quando úmidos imbricados, ápice do lobo apiculado, plano, células alongadas, paredes das células formando trigônios, ocelos ausentes, estilete filiforme, apêndice laminar do estilete ausente, 4-6 células compr., lóbulo cilíndrico, ereto e próximo do caulídio, abertura do lóbulo voltada para a base, ventral e dorsal reta, anfigastros bífidos, sinus 1/4-1/5 compr., margem inteira, largura em relação ao caulídio $1-3 x$, margem plana, base decurrente, distantes, brácteas femininas denteadas a laciniadas, incurvadas. Perianto plicado, 4-5, liso.

Material examinado: Minas Gerais, Conceição do Mato Dentro, Vital 1217 (SP87120).

Ocorre nos estados de AM, BA, MG, PA, PE, PR, RJ, RS, SC e SP. Na Serra do Cipó, cresce em rocha. Esta espécie apresenta o hábito delgado e semelhante a $F$. brasiliensis, diferenciando-se por apresentar ápice dos filídios agudo e perianto pluriplicado.

1.2. Frullania beyrichiana (Lehm. \& Lindenb.) Lehm. \& Lindenb. in Gottsche et al., Syn. Hepat.: 46a. 1845.

Fig. 43 A-D

Gametófitos medianos, ascendentes ou pêndulos, ramificações pinadas, lobos quando úmidos imbricados, ápice do lobo agudo, plano, paredes das células formando trigônios, ocelos ausentes, estilete filiforme, apêndice laminar do estilete ausente, 4-6 células compr., lóbulo cilíndrico, ereto e próximo do caulídio, abertura do lóbulo voltada para a base, ventral e dorsal reta, anfigastros bífidos, sinus 1/4-1/5 compr., margem inteira, largura em relação ao caulídio 1-3x, margem plana, base reta, distantes, brácteas femininas denteadas a laciniadas, planas. Perianto plicado, 4-5, liso.

Material examinado: Minas Gerais, Congonhas do Norte, Pirani et al. 4148 (SP284247, SPF171260).

Ocorre nos estados de AC, BA, ES, GO, MG, MT, PA, PE, RJ, RS e SP. Na Serra do Cipó, cresce em tronco vivo. Esta espécie apresenta o hábito semelhante a F. brasiliensis, diferenciando-se por apresentar ápice dos filídios agudo e perianto 4plicado.

1.3. Frullania brasiliensis Raddi, Soc. Ital. Att. Sci. Mod. 19: 36. 1822.

Fig. 43 E-J

Gametófitos medianos, ascendentes ou pêndulos, ramificações pinadas, lobos quando úmidos imbricados, ápice do lobo apiculado, incurvado, células alongadas, paredes das células formando trigônios, ocelos ausentes, estilete filiforme, apêndice laminar do estilete ausente, 4-6 células compr., lóbulo cilíndrico, ereto e próximo do caulídio, abertura do lóbulo voltada para a base, ventral e dorsal reta, anfigastros bífidos, sinus 1/4-1/5 compr., margem inteira, largura em relação ao caulídio 1-3x, margem incurvada, base curva, sobrepostos, brácteas femininas inteiras, planas. Perianto inflado, terete (sem pregas), liso.

Material examinado: Minas Gerais, Conceição do Mato Dentro, Vital 1228 (SP87126); O. Yano 512, 514 (SP132047; SP132048); Congonhas do Norte, Pirani et al. 4150 (SP284252); Itambé do Mato Dentro, Vital 7623 p.p. (SP136578); Santana do Riacho, Pirani et al. 10380 (SP230734, SPF171258); O. Yano \& Wanderley 10736, 10764, 10781, 10783, 10817, 10820, 10825, 10826, 10853 p.p., 10895 (SP220430; SP220458; SP220474; SP220476; SP220510; SP220513; SP220518; SP220519; SP220546; SP220588); Pirani et al. 5694, 5705, 12299 p.p., 12302 (SP432337, SPF; SP432338, SPF; SP386341, SPF; SP386340, SPF); Câmara 1961 (SP419673); Dias Neto 178 (SP419795).

Associada a Henicodium geniculatum (Mitt.) W.R. Buck, Schiffneriolejeunea polycarpa (Nees) Gradst. e Schlotheimia rugifolia (Hook.) Schwägr. Ocorre nos estados de AL, BA, CE, DF, ES, GO, MG, PE, RJ, RS, SC e SP. Na Serra do Cipó, cresce em rocha e tronco vivo. Esta é uma espécie bastante comum e facilmente diferenciada principalmente pelo perianto inflado e sem pregas.

1.4. Frullania caulisequa (Nees) Nees in Gottsche et al., Syn. Hepat.: 448. 1845.

Fig. $43 \mathrm{~K}-\mathrm{N}$

Gametófitos pequenos, prostrados, ramificações irregulares, lobos quando úmidos imbricados, ápice do lobo obtuso, plano, células isodiamétricas, paredes das células formando trigônios, ocelos ausentes, estilete filiforme, apêndice laminar do estilete ausente, 4-6 células compr., lóbulo cilíndrico, obliquo e distante do caulídio, ventral e dorsal reta, anfigastros bífidos, sinus $1 / 3$ compr., margem inteira, largura em relação ao caulídio 1-3x, margem plana, base reta, distantes, brácteas femininas inteiras, planas. Perianto plicado, 4-5, liso.

Material examinado: Minas Gerais, Santana do Riacho, O. Yano \& Wanderley 10633, 10635 (SP220328; SP220330).

Ocorre nos estados de AC, AL, BA, CE, DF, ES, GO, MG, MT, PA, PE, RJ, RR, RS, SC, SE e SP. $\mathrm{Na}$ Serra do Cipó, cresce em tronco vivo. Esta espécie apresenta o hábito semelhante as espécies da família Lejeuneaceae, prostrado e verde oliva. 


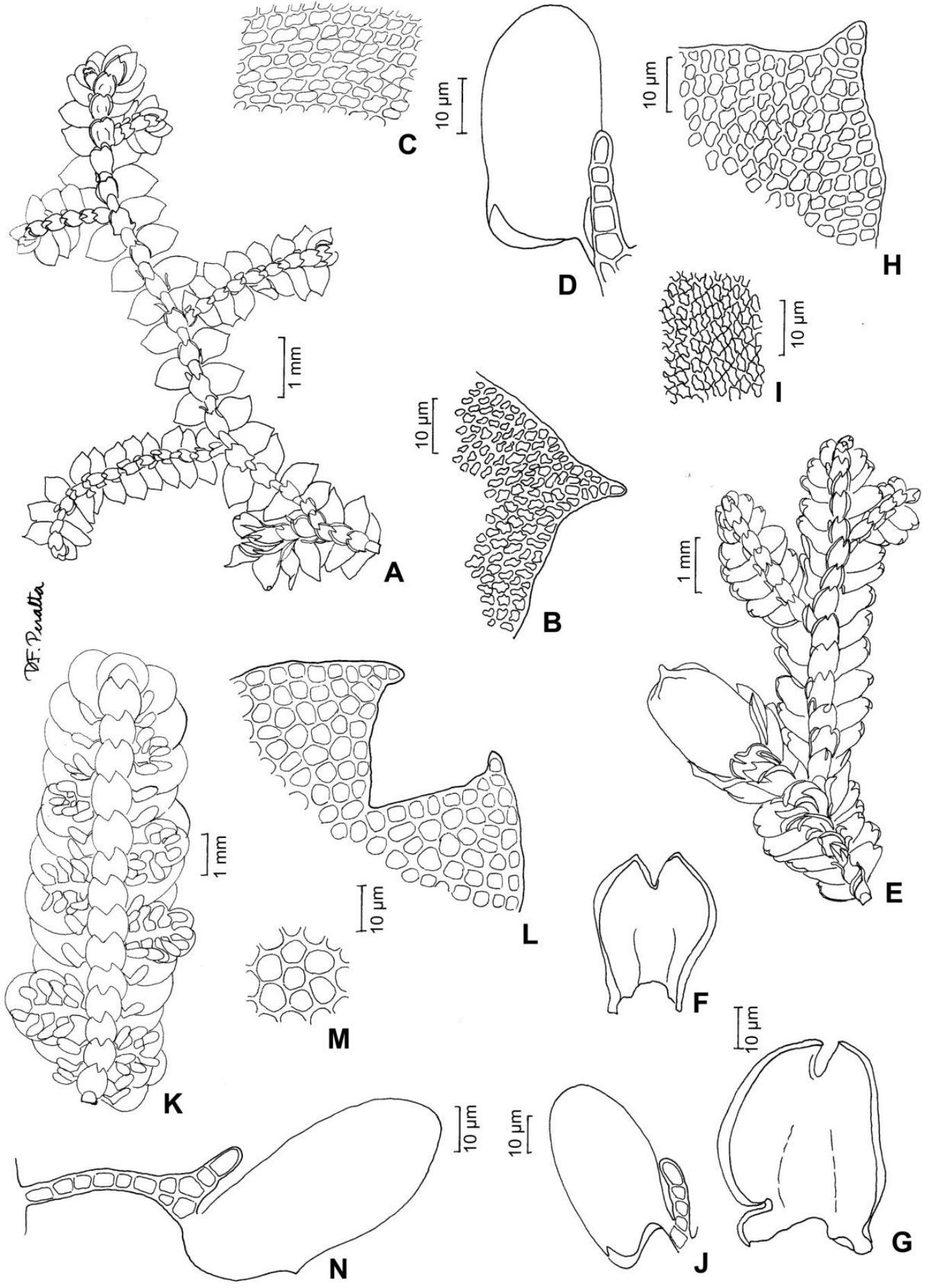

Fig. 43. Frullania beyrichiana (Lehm. \& Lindenb.) Lehm. \& Lindenb. A. aspecto do gametófito. B. ápice do filídio. C. células da lâmina do filídio. D. lóbulo com estilete. Frullania brasiliensis Raddi. E. aspecto do gametófito. F-G. anfigastros. H. ápice do filídio. I. células da lâmina do filídio. J. lóbulo com estilete. Frullania caulisequa (Nees) Nees. K. aspecto do gametófito. L. células do ápice do anfigastro. M. células da lâmina do filídio. N. lóbulo com estilete (A-D. Pirani et al. 4148; E-J. Vital 1228; K-N. O. Yano \& Wanderley 10633). 
1.5. Frullania ericoides (Nees) Mont., Ann. Sci. Nat. Bot. sér. 2, $12: 51.1839$.

Fig. 44 A-F

Gametófitos medianos, prostrados, ramificações irregulares, lobos quando úmidos esquarrosos, ápice do lobo obtuso, plano, células alongadas, paredes das células formando trigônios, ocelos ausentes, estilete foliáceo (lanceolado), apêndice laminar do estilete ausente, 4-6 células compr., lóbulo formato de capacete, eretos e próximos do caulídio, abertura do lóbulo voltada para a base, ventral menor (falcado ou pregreado) e dorsal reta, anfigastros bífidos, sinus 1/4$1 / 5$ compr., margem inteira, largura em relação ao caulídio 4-6x, margem plana, base curva, sobrepostos, brácteas femininas inteiras, planas ou incurvadas. Perianto plicado, 4-5, tuberculado.

Material examinado: Minas Gerais, Santana do Riacho, O. Yano \& Wanderley 10626, 10727, 10729 (SP220321; SP220421; SP220423).

Ocorre nos estados de AC, AL, AM, BA, CE, DF, ES, FN, GO, MG, MS, MT, PB, PE, PR, RJ, RS, SC, SE e SP. Na Serra do Cipó, cresce em tronco vivo. Esta é uma espécie comum e amplamente distribuída, os filídios quando secos são imbricados e quando úmidos são caracteristicamente esquarrosos.

1.6. Frullania gibbosa Nees in Montagne, Ann. Sci. Nat. Bot. sér. 2, 14: 333. 1840.

Fig. $44 \mathrm{G}-\mathrm{K}$

Gametófitos medianos, prostrados, ramificações irregulares, lobos quando úmidos imbricados, ápice do lobo obtuso, plano, células alongadas, paredes das células formando trigônios, ocelos ausentes, estilete foliáceo (lanceolado), apêndice laminar do estilete presente, 4-6 células compr., lóbulo formato de capacete, oblíquos e distantes do caulídio, abertura do lóbulo voltada para a base, ventral menor (falcado ou pregueada) e dorsal reta, anfigastros bífidos, sinus 1/4-1/5 compr., margem inteira, largura em relação ao caulídio 4-6x, plana, base decurrente, sobreposta, brácteas femininas inteiras, planas ou incurvadas. Perianto plicado, 4-5, liso.

Material examinado: Minas Gerais, Santana do Riacho, Dias Neto 101 p.p. (SP419739).

Associada a Donnellia commutata (Müll. Hal.) W.R. Buck. Ocorre nos estados do AC, AM, AP, BA, DF, ES, GO, MG, MS, MT, PA, PB, PE, PR, RJ, RR, SC e SP. Na Serra do Cipó ocorre em tronco de árvore. A presença de uma prega laminar no estilete é facilmente utilizada para a identificação desta espécie.
1.7. Frullania glomerata (Lehm. \& Lindenb.) Nees \& Mont., Ann. Sci. Nat. Bot. sér. 2, 9: 46.1838.

Fig. 44 L-Q

Gametófitos medianos, prostrados,
ramificações irregulares, lobos quando úmidos imbricados, ápice do lobo obtuso, plano, células alongadas, paredes das células formando trigônios, ocelos ausentes, estilete foliáceo (lanceolado), apêndice laminar do estilete ausente, 4-6 células compr., lóbulo formato de capacete, eretos e próximos do caulídio, abertura do lóbulo voltada para a base, ventral e dorsal reta, anfigastros bífidos, sinus 1/4-1/5 compr., margem inteira ou com um dente lateral, largura em relação ao caulídio 4-6x, margem plana, base curva, sobrepostos, brácteas femininas inteiras, planas ou incurvadas. Perianto plicado, 4-5, tuberculado.

Material examinado: Minas Gerais, Santana do Riacho, O. Yano \& Wanderley 10704, 10738, 10760, 10808 p.p., 10833, 10842 (SP220399; SP220432; SP220454; SP220501; SP220526; SP220535); Câmara 1870 (SP419632).

Associada a Frullania neesii Lindenb. Ocorre nos estados de BA, CE, DF, ES, GO, MG, MS, MT, PR, RJ, RS e SP. Na Serra do Cipó, cresce em tronco vivo. Esta espécie apresenta o hábito semelhante a $F$. ericoides, porém os filídios não ficam esquarrosos quando úmidos e a abertura do lóbulo é perpendicular ao caulídio, ca. $45^{\circ}$ em $F$. ericoides.

1.8. Frullania neesii Lindenb. in Gottsche et al., Syn. Hepat.: 450. 1845.

Fig. 44 R-X

Gametófitos pequenos, prostrados, ramificações irregulares, lobos quando úmidos imbricados, ápice do lobo obtuso, plano, células isodiamétricas, paredes das células regularmente espessadas e sem trigônios, ocelos ausentes, estilete filiforme, apêndice laminar do estilete ausente, 4-6 células compr., lóbulo cilíndrico, ereto e próximo do caulídio, abertura do lóbulo voltada para a base, ventral e dorsal reta, anfigastros bífidos, sinus 1/4-1/5 compr., margem inteira, largura em relação ao caulídio 1-3x, margem plana, base reta, distantes, brácteas femininas inteiras, planas. Perianto plicado, 4-5, liso.

Material examinado: Minas Gerais, Conceição do Mato Dentro, O. Yano 490, 498 (SP132042; SP132044); Santana do Riacho, Serra da Bandeirinha, O. Yano \& Wanderley 10630, 10708, 10802, 10803 p.p., 10804, 10808 p.p., 10809, 10877, 10903 p.p. (SP220325; SP220403; SP220495; SP220496; SP220497; SP220501; SP220502; SP220570; SP220596). 
Flora da Serra do Cipó, Minas Gerais: Briófitas (Anthocerotophyta, Bryophyta e Marchantiophyta)
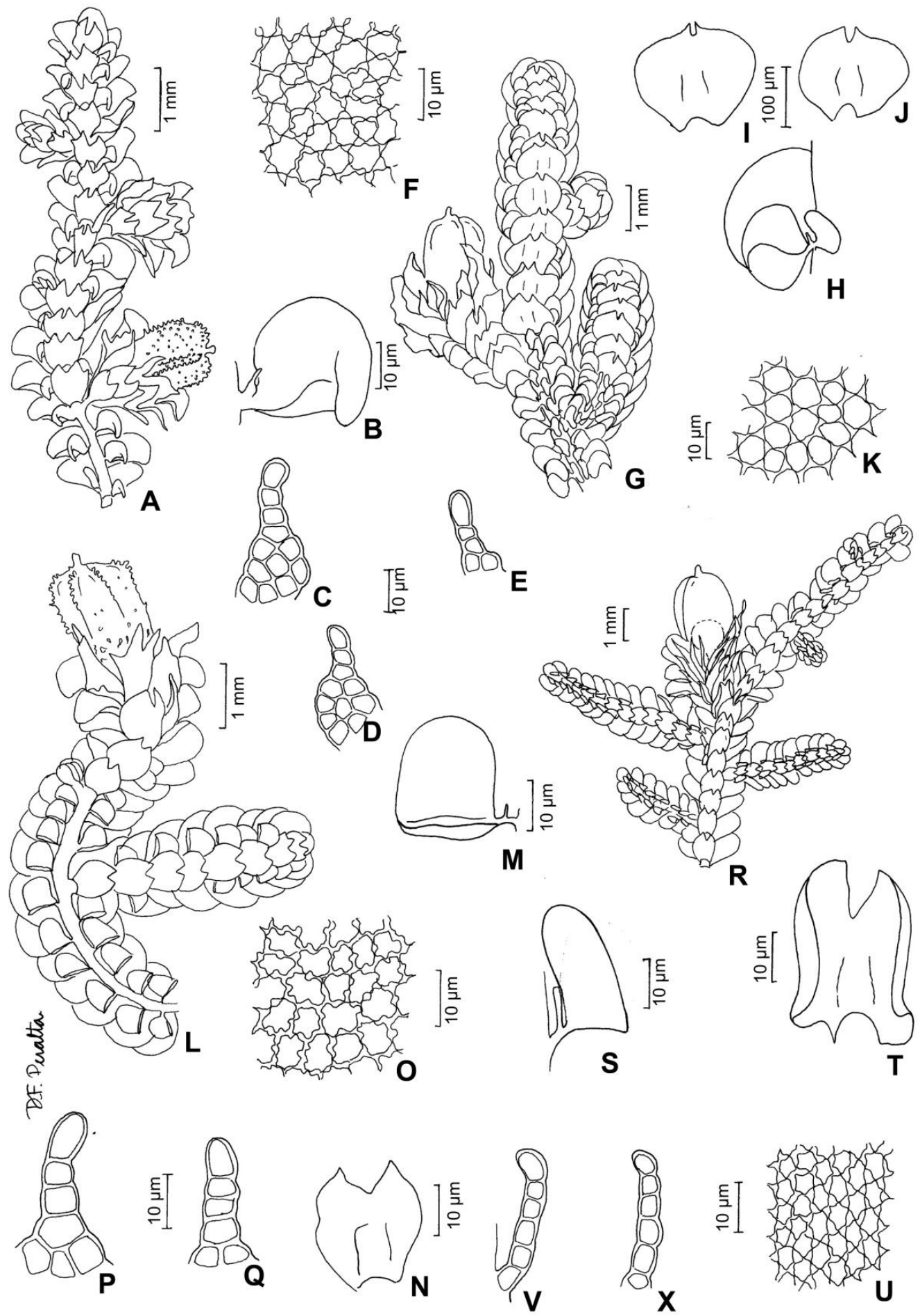

Fig. 44. Frullania ericoides (Nees) Mont. A. aspecto do gametófito. B. lóbulo. C-E. estiletes. F. células da lâmina do filídio. Frullania gibbosa Nees. G. aspecto do gametófito. H. filídio, lóbulo e estilete. I-J. anfigastros. K. células da lâmina do filídio. Frullania glomerata (Lehm. \& Lindenb.) Nees \& Mont. L. aspecto do gametófito. M. lóbulo. N. anfigastro. O. células da lâmina do filídio. P-Q. estiletes. Frullania neesii Lindenb. R. aspecto do gametófito. S. lóbulo. T. anfigastro. U. células da lâmina do filídio. V-X. estiletes (A-F. O. Yano \& Wanderley 10626; G-K. Dias Neto 101 p.p.; L-Q. O. Yano \& Wanderley $10704 ;$ R-X. O. Yano 490). 
Associada a Frullania dilatata (L.) Dumort., Lejeunea laetevirens Nees \& Mont. e Cheilolejeunea xanthocarpa (Lehm. \& Lindenb.) Malombe. Ocorre nos estados de AC, AM, BA, CE, DF, ES, GO, MG, MT, PB, PE, RJ, RR, RS, SE e SP. Na Serra do Cipó, cresce em tronco vivo. Esta é uma espécie facilmente diferençável pelo hábito pequeno e pela coloração fortemente vermelho-vinácea.

\section{Jungermanniaceae}

Gametófitos folhosos, marrons, verde-escuros ou vináceos, estolões ausentes, hábito ereto ou prostrado, ramificações tipo Frullania, ventral intercalar ou lateral intercalar. Filídios súcubos ou opostos, inserção obliqua, margem inteira, região ventral reta, região dorsal plana, sem células diferenciadas. Células quadrático irregulares, parede celular uniformemente delgada, cutícula lisa, trigônios presentes ou ausentes, células da margem iguais as interiores. Ocelos ausentes. Anfigastro ausente ou inteiro e pequenos (ca. 1/3 a 1/2x larg. do caulídio). Rizóides monomórficos, restritos à base dos ramos, incolores ou avermelhados. Gametângios terminais, anterídios em eixos especializados com filídios modificados, arquegônios perianto, liso ou plicado. Cápsula esférica.

É uma família amplamente distribuída no Brasil, primeiramente relacionada as áreas de planalto, caracterizada principalmente pelo ausência de anfigastro e os filídios inteiros. Ocorre principalmente como terrestre, corticícola e rupícola. Para a identificação das espécies é necessário análise da morfologia das células da lâmina do filídio. No Brasil ocorrem seis gêneros e 26 espécies; na Serra do Cipó ocorrem três gêneros e três espécies.

Bibliografia básica: Gradstein \& Costa (2003); Gradstein et al. (2001); Yano \& Peralta (2008).

Chave para os gêneros

1. Filídios bífidos

1. Anastrophyllum

1'. Filídios inteiros.

2. Filídios distintamente intercalados, trigônios ausentes, hábito terrestre

2. Jungermannia

2'. Filídios distintamente opostos, trigônios grandes, hábito corticícola 3. Syzygiella

\section{Anastrophyllum (Spruce) Steph.}

Gametófitos folhosos, marrons ou verdeescuros, estolões ausentes, hábito ereto, ramificações do tipo ventral intercalar ou lateral intercalar. Filídios súcubos, inserção oblíqua, bífidos, margem inteira, na região ventral reta, margem na região dorsal plana, sem células diferenciadas. Células quadráticoirregulares, parede celular uniformemente espessada, cutícula lisa, trigônios presentes, células da margem iguais as interiores. Ocelos ausentes. Anfigastro ausente. Gametângios terminais, anterídios em eixos especializados com filídios modificados, perianto plicado. Cápsula esférica. Reprodução vegetativa por ramos geminíferos.

1.1. Anastrophyllum piligerum (Nees) Spruce, J. Bot. 14: 235. 1876.

Fig. 45 A-F

Gametófitos folhosos, hábito ereto. Filídios súcubos, bífidos, margem inteira, sem células diferenciadas. Células quadrático-irregulares, parede celular uniformemente espessada, cutícula lisa, trigônios presentes, células da margem iguais as interiores. Anfigastro ausente. Gametângios terminais, perianto, plicado. Cápsula esférica.

Material examinado: Minas Gerais, Santana do Riacho, Câmara 1952, 1957 (SP419665; SP419669).

Ocorre nos estados de BA, MG, RJ e SP. Na Serra do Cipó, cresce em rocha. A coloração verdeoliva e o filídio bilobulado são facilmente visualizados para a identificação desta espécie.

\section{Jungermannia $\mathrm{L}$.}

Gametófitos folhosos, verde-escuros, estolões ausentes, hábito ereto ou prostrado, ramificações do tipo ventral intercalar ou lateral intercalar. Filídios súcubos, inserção oblíqua, inteiros, margem inteira, na região ventral reta, margem na região dorsal plana, sem células diferenciadas. Células quadráticoirregulares, parede celular uniformemente delgada, cutícula lisa, trigônios ausentes, células da margem iguais as interiores. Ocelos ausentes. Anfigastro ausente. Gametângios terminais, anterídios em eixos especializados com filídios modificados, perianto plicado. Cápsula esférica. Reprodução vegetativa por ramos geminíferos. 
Flora da Serra do Cipó, Minas Gerais: Briófitas (Anthocerotophyta, Bryophyta e Marchantiophyta)

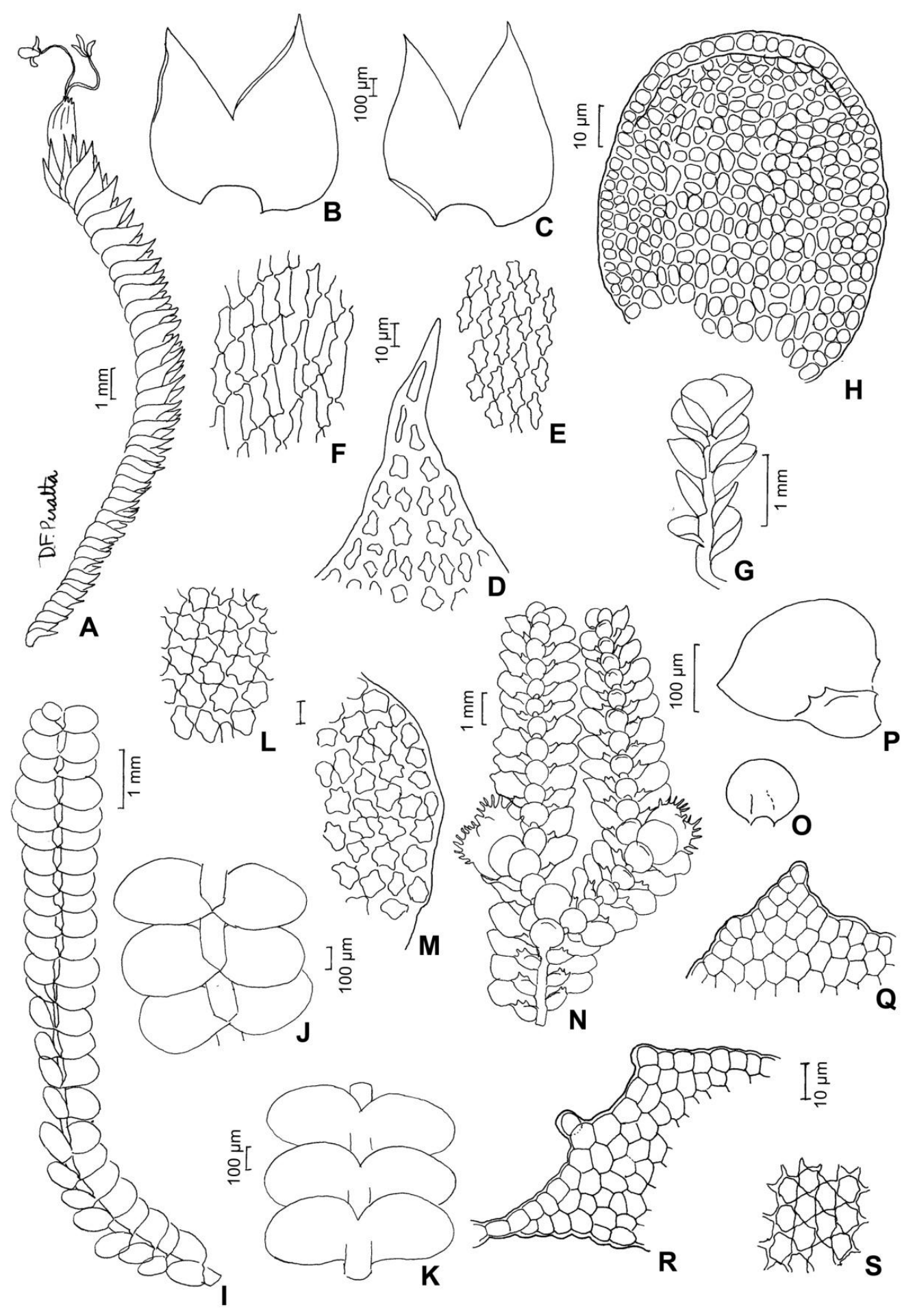

Fig. 45. Anastrophyllum piligerum (Nees) Spruce. A. aspecto do gametófito. B-C. filídios. D. ápice do filídio. E. células da lâmina do filídio. F. células da base do filídio. Jungermannia amoena Lindenb. \& Gottsche. G. aspecto do gametófito. H. filídio. Syzygiella anomala (Lindenb. \& Gottsche) Steph. I. aspecto do gametófito. J. vista dorsal do gametófito. K. vista ventral do gametófito. L. células da lâmina do filídio. M. células da margem do filídio. Acanthocoleus aberrans (Lindenb. \& Gottsche) Kruijt. N. aspecto do gametófito. O. anfigastro. P. filídio. Q. detalhe do ápice do filídio. R. células do lóbulo do filídio. S. células da lâmina do filídio (A-F. Câmara 1952; G-H. O. Yano \& Wanderley 10863 p.p.; I-M. Câmara et al. 2065 p.p.; N-S. O. Yano \& Wanderley 10610). 
2.1. Jungermannia amoena Lindenb. \& Gottsche in Gottsche et al., Syn. Hepat.: 674. 1847.

Fig. $45 \mathrm{G}-\mathrm{H}$

Gametófitos folhosos, hábito ereto ou prostrado. Filídios súcubos, ovados, margem inteira, sem células diferenciadas. Células quadráticoirregulares, parede celular uniformemente delgada, cutícula lisa, trigônios ausentes, células da margem iguais as interiores. Anfigastro ausente. Gametângios terminais, perianto, plicado. Cápsula esférica.

Material examinado: Minas Gerais, Santana do Riacho, Serra da Bandeirinha, O. Yano \& Wanderley 10863 p.p. (SP220556).

Associada a Marchantia chenopoda L., Cheilolejeunea acutangula (Nees) Grolle, Kurzia capillaris (Sw.) Grolle. Ocorre nos estados de ES, MG, PA, PI, RJ, SC e SP. Na Serra do Cipó, cresce em rocha. Esta espécie apresenta o hábito delicado e as células da lâmina do filídio com as paredes delgadas.

\section{Syzygiella Spruce}

Gametófitos folhosos, marrons, verde-escuros ou vináceos, estolões ausentes, hábito ereto ou prostrado, ramificações do tipo ventral intercalar ou lateral intercalar. Filídios opostos, inserção oblíqua, inteiros, margem inteira, região ventral reta, região dorsal plana, sem células diferenciadas. Células quadrático-irregulares, parede celular uniformemente espessada, cutícula rugosa, trigônios presentes, células da margem iguais as interiores. Ocelos ausentes. Anfigastro ausente. Gametângios terminais, anterídios em eixos especializados com filídios modificados, perianto plicado. Cápsula esférica. Reprodução vegetativa por ramos geminíferos.

3.1. Syzygiella anomala (Lindenb. \& Gottsche) Steph., Bull. Herb. Boissier. sér. 2, 2: 471. 1902.

Fig. 45 I-M

Gametófitos folhosos, hábito ereto. Filídios opostos, oval-ligulados, margem inteira, sem células diferenciadas. Células quadrático-irregulares, parede celular uniformemente espessada, cutícula rugosa, trigônios presentes, células da margem iguais as interiores. Anfigastro ausente. Gametângios terminais, perianto, plicado. Cápsula esférica.

Material examinado: Minas Gerais, Santana do Riacho, Câmara et al. 2065 p.p. (SP419700).

Associada a Plagiochila macrostachya Lindenb. Ocorre nos estados de MG, PR e RJ. Na Serra do Cipó, cresce em tronco caído. Esta espécie é facilmente diferençável pelos filídios opostos e as células com os trigônios grandes.

\section{Lejeuneaceae}

Gametófitos folhosos, amarelados, marrons, pretos ou verde-claros, estolões ausentes, hábito pendente, ascendente ou prostrado, ramificações tipo Lejeunea ou tipo Frullania. Filídios íncubos, inserção obliqua, margem crenulada, inteira ou denteada, região ventral lobulada (angulo reto ao caulídio), região dorsal plana, sem ou com células diferenciadas. Células hexagonais ou quadrático irregulares, parede celular uniformemente delgada ou espessada, cutícula lisa, rugosa ou papilosa, trigônios presentes ou ausentes, células da margem iguais as interiores. Ocelos ausentes, poucos ocelos distribuídos em fileira ou muitos ocelos espalhados. Anfigastro bilobado ou inteiro, pequenos (ca. 1 a $2 x$ larg. do caulídio) ou grandes (ca. 3 a 10x larg. do caulídio), bífido, crenulado, denteado ou inteiro. Rizóides monomórficos, em tufos na base dos anfigastros, incolores. Gametângios laterais em pequenas ramificações, anterídios em eixos especializados com filídios modificados, arquegônios perianto, liso, plicado ou quilhado. Cápsula esférica.

É uma família amplamente distribuída no Brasil, caracterizada principalmente pelo lóbulo perpendicular ao caulídio. Ocorre principalmente nos mais diversos substratos. Para a identificação das espécies é necessário análise da morfologia do lóbulo, das células da lâmina do filídio e do perianto. No Brasil ocorrem 63 gêneros e 439 espécies; na Serra do Cipó ocorrem 13 gêneros e 32 espécies.

Bibliografia básica: Bastos (2004); Bischler et al. (1963); Gradstein (1994); Gradstein \& Costa (2003); Gradstein \& Ilkiu-Borges (2009); Gradstein et al. (2001); Lemos-Michel (2001); Reiner-Drehwald (2000); Schuster (1980); Yano \& Peralta (2008); Zartman \& Ilkiu-Borges (2007).

1. Anfigastro ausente

1'. Anfigastro presente.

2. Anfigastro inteiro.

3. Lóbulo involuto, ca. 2-3 vezes

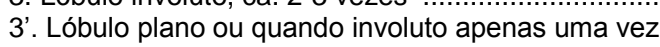

4. Anfigastro circular na maioria das vezes distantes.

5. Ramificação dicotômica

5'. Ramificação irregular.

6. Coloração verde-esbranquiçada, perianto sem dentes

5. Cololejeunea

3. Anoplolejeunea

9. Marchesinia

4. Cheilolejeunea p.p. 
6'. Coloração castanho-escura a preto, perianto denteado.

7. Lóbulo com 2-3 dentes

1. Acanthocoleus

7'. Lóbulo com 1 dente

8. Lopholejeunea

4'. Anfigastro irregular com ápice truncado (reniforme), imbricados.

8. Ápice das ramificações com ramos flagelíferos

8'. Ápice das ramificações sem ramos flagelíferos.

9. Filídios com ápice agudo, perianto quilhado.

9'. Filídios com ápice oblongo, perianto pregueado.

10. Lóbulo com 6-8 dentes

2. Acrolejeunea

10'. Lóbulo com 1-2 dentes

10. Mastigolejeunea

2'. Anfigastro bífido.

11. Anfigastros com largura igual a largura do caulídio, lóbulo normalmente inflado

11'. Anfigastros mais largos que o caulídio, lóbulo não inflado.

12. Sinus estreito, periantos em fileiras ....

12 . Sinus amplo, perianto não em fileiras.

13. Papila hialina distal, trigônios usualmente bem desenvolvidos, oleocorpos grandes........ 4. Cheilolejeunea p.p.

13'. Papila hialina proximal, trigônios usualmente pequenos ou ausentes, oleocorpos pequenos ........ 7. Lejeunea

\section{Acanthocoleus R.M. Schust.}

Gametófitos verde-escuros a marrons, pequenos, delicados, ramos prostrados, lobos orbiculares, ápice denteado, margem inteira ou denteada, células mais longas que largas, lisas, trigônios grandes, oleocorpos segmentados, ocelos ausentes, lóbulos aplainados, dentes 1 ou 2 , anfigastros inteiros, margem inteira, largura em relação ao caulídio $1-3 x$, base decurrente, quilhas do perianto 3 ou 4 ou 5 , laciniadas.

1.1. Acanthocoleus aberrans (Lindenb. \& Gottsche) Kruijt, Bryophyt. Biblioth. 36: 62. 1988.

Fig. $45 \mathrm{~N}-\mathrm{S}$

Gametófitos verde-escuros a marrons, pequenos, delicados, ramos prostrados, ramificações tipo Lejeunea, hialoderme presente, merófito ventral 23(-4) células, lobos orbiculares, ápice denteado, margem inteira ou denteada, margem com células clorofiladas, células mais longas que largas, lisas, trigônios grandes, oleocorpos segmentados, ocelos ausentes, lóbulos aplainados, tamanho em relação ao filídio $1 / 4-1 / 6$, às vezes reduzidos, ápice do lóbulo plano, dentes 1 ou 2, anfigastros inteiros, margem inteira, largura em relação ao caulídio $1-3 x$, base decurrente, quilhas do perianto 3 ou 4 ou 5 , laciniadas. Reprodução vegetativa ausente.

Material examinado: Minas Gerais, Santana do Riacho, O. Yano \& Wanderley 10610 (SP220305); Serra da Bandeirinha, O. Yano \& Wanderley 10725, 10728, 10773 (SP220419; SP220422; SP220466).

Ocorre nos estados de AL, DF, ES, GO, PR, RJ, RS, SC e SP. Na Serra do Cipó, cresce em tronco vivo.

\section{Acrolejeunea (Spruce) Schiffn.}

Gametófitos verde-claros a amarelados ou verde-escuros a marrons, medianos, ramos prostrados, ramificações tipo Lejeunea, hialoderme presente, lobos orbiculares, sobrepostos, ápice obtuso, margem inteira, com células clorofiladas, lisas, trigônios grandes, oleocorpos homogêneos (agrupados), ocelos ausentes, lóbulos aplainados, nunca reduzidos, ápice do lóbulo plano ou involuto, anfigastros inteiros, margem inteira, perianto pluriplicado ou com 5 quilhas, inteiras.

\section{Chave para as espécies}

2.1. Acrolejeunea emergens (Mitt.) Steph. in Engler, Pflanzenwelt Ost'Afrikas C: 65. 1895.

Fig. 46 A-H

Gametófitos verde-claros a amarelados ou verde-escuros a marrons, medianos, ramos prostrados, ramificações tipo Lejeunea, hialoderme presente, merófito ventral 4-6(8-10) células, lobos orbiculares, sobrepostos, ápice obtuso, margem inteira, com células clorofiladas, células mais longas que largas, lisas, trigônios grandes, oleocorpos homogêneos (agrupados), ocelos ausentes, lóbulos aplainados, tamanho em relação ao filídio 1/2-3/4, nunca reduzidos, ápice do lóbulo plano ou involuto, dentes 2 ou 4, anfigastros inteiros, sobrepostos, 
margem inteira, largura em relação ao caulídio 4-5x, base curva, perianto pluriplicado ou com 5 quilhas, inteiras. Reprodução vegetativa por filídios caducos.

Material examinado: Minas Gerais, Santana do Riacho, O. Yano \& Wanderley 10852, 10743, 10763 (SP220545; SP220437; SP220457).

Ocorre nos estados de AC, AM, BA, CE, DF, ES, GO, MA, MG, MS, MT, PA, RJ, RO, RR e SP. Na Serra do Cipó, cresce em tronco vivo.

2.2. Acrolejeunea torulosa (Lehm. \& Lindenb.) Schiffn. in Engler \& Prantl, Natürl. Pflanzenfam. ed. 1, 3(1): 128. 1893.

Fig. 46 I-N

Gametófitos verde-claros a amarelados ou verde-escuros a marrons, medianos, ramos prostrados, ramificações tipo Lejeunea, hialoderme presente, merófito ventral 4-6(8-10) células, lobos orbiculares, sobrepostos, ápice obtuso, margem inteira, com células clorofiladas, células mais longas que largas, lisas, trigônios grandes, oleocorpos homogêneos (agrupados), ocelos ausentes, lóbulos aplainados, tamanho em relação ao filídio 1/2-3/4, nunca reduzidos, ápice do lóbulo plano ou involuto, dentes 5 ou 8, anfigastros inteiros, sobrepostos, margem inteira, largura em relação ao caulídio 4-5x, base curva, perianto pluriplicado ou com 5 quilhas, inteiras. Reprodução vegetativa por filídios caducos.

Material examinado: Minas Gerais, Santana do Riacho, O. Yano \& Wanderley 10614, 10741, 10805, 10835 (SP220309; SP220435; SP220498; SP220528).

Ocorre nos estados de AC, AL, AM, BA, CE, ES, GO, MA, MG, MS, MT, PA, PR, RJ, RO, RR, RS, SP e TO. Na Serra do Cipó, cresce em tronco vivo. Esta é uma espécie facilmente diferenciada pela existência de 5 a 8 dentes na margem do lóbulo e pelos ramos que produzem filídios caducos.

\section{Anoplolejeunea (Spruce) Schiffn.}

Gametófitos verde-claros a amarelados, medianos, ramos prostrados, hialoderme presente, lobos orbiculares, sobrepostos, ápice obtuso, margem inteira, células isodiamétricas, lisas, trigônios pequenos, oleocorpos segmentados, ocelos ausentes, agrupados, lóbulos claviformes, inflados, ápice do lóbulo involuto, dentes 1, papila hialina distal, anfigastros inteiros, espaçados, margem inteira, largura em relação ao caulídio $1-3 x$, base curva, perianto pluriplicado ou com 5 quilhas, inteiras.

3.1. Anoplolejeunea conferta (Meissn. ex Spreng.) A. Evans, Bull. Torrey Bot. Club 35: 175. 1908.

Fig. 46 O-S

Gametófitos verde-claros a amarelados, medianos, ramos prostrados, hialoderme presente, merófito ventral 2-3(-4) células, lobos orbiculares, sobrepostos, ápice obtuso, margem inteira, com células clorofiladas, células isodiamétricas, lisas, trigônios pequenos, oleocorpos segmentados, ocelos ausentes, agrupados, lóbulos claviformes, inflados, tamanho em relação ao filídio $1 / 3$, às vezes reduzidos, ápice do lóbulo involuto, dentes 1, papila hialina distal, anfigastros inteiros, espaçados, margem inteira, largura em relação ao caulídio 1-3x, base curva, perianto pluriplicado ou com 5 quilhas, inteiras. Reprodução vegetativa ausente.

Material examinado: Minas Gerais, Conceição do Mato Dentro, O. Yano 497 (SP132043); Santana do Riacho, Dias Neto 280 (SP419849).

Ocorre nos estados de AL, BA, ES, MG, PA, PE, PR, RJ, RS, SC e SP. Na Serra do Cipó, cresce em tronco vivo. Esta espécie apresenta uma coloração verde-amarelada e os lóbulos são fortemente inflados.

\section{Cheilolejeunea (Spruce) Schiffn.}

Gametófitos verde-claros a amarelados, medianos, ramos prostrados, ramificações tipo Lejeunea, hialoderme presente, lobos orbiculares, sobrepostos, ápice agudo ou obtuso, margem inteira, células clorofiladas, ápice inflexo, células isodiamétricas, lisas, trigônios grandes, oleocorpos homogêneos (agrupados), ocelos ausentes, lóbulos quadráticos a orbiculares, inflados, às vezes reduzidos, ápice do lóbulo involuto ou reto, papila hialina distal, anfigastros bífidos ou inteiros, sobrepostos ou espaçados, margem inteira, base curva, quilhas do perianto 4 , inteiras. 
Flora da Serra do Cipó, Minas Gerais: Briófitas (Anthocerotophyta, Bryophyta e Marchantiophyta)

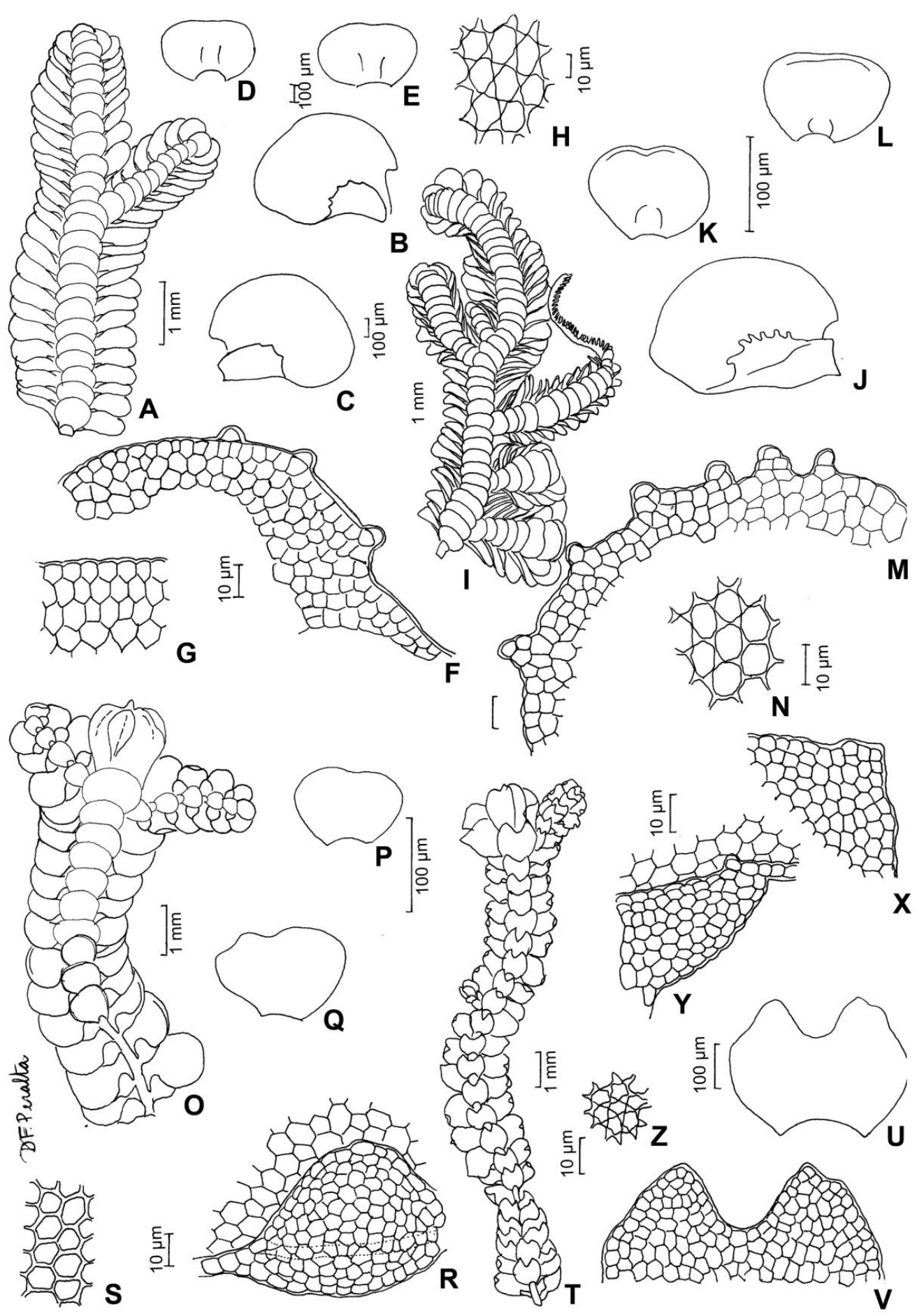

Fig. 46. Acrolejeunea emergens (Mitt.) Steph. A. aspecto do gametófito. B-C. filídios. D-E. anfigastros. F. células do lóbulo do filídio. G. células da margem do filídio. H. células da lâmina do filídio. Acrolejeunea torulosa (Lehm. \& Lindenb.) Schiffn. I. aspecto do gametófito. J. filídio. K-L. anfigastros. M. células do lóbulo do filídio. N. células da lâmina do filídio. Anoplolejeunea conferta (Meissn. ex Spreng.) A. Evans. O. aspecto do gametófito. P-Q. anfigastros. R. células do lóbulo do filídio. S. células da lâmina do filídio. Cheilolejeunea acutangula (Nees) Grolle. T. aspecto do gametófito. U. anfigastro. V. detalhe do ápice do anfigastro. X. células do ápice do filídio. Y. células do lóbulo do filídio. Z. células da lâmina do filídio (A-H. O. Yano \& Wanderley 10852; I-N. O. Yano \& Wanderley 10614; O-S. O. Yano 497; T-Z. O. Yano 501). 


\section{Chave para as espécies}

1. Anfigastro inteiro.

2. Lóbulo inflado, 1 dente com uma célula longa no ápice do lóbulo.

4.6. C. holostipa

2'. Lóbulo involuto, 1 dente simples no ápice do lóbulo.

3. Anfigastros sobrepostos

3'. Anfigastros espaçados

4.10. C. xanthocarpa

1'. Anfigastro bífido.

4. Merófito ventral com 2-3(-4) células.

5. Abertura do sinus ca. $45^{\circ}$

5'. Abertura do sinus estreita.

6. Trigônios pequenos; ápice do lóbulo plano; base reta; margem com rizóides

6'. Trigônios grandes; ápice do lóbulo involuto; base curva; margem inteira

4'. Merófito ventral com 4-6(8-10) células.

7. Trigônios pequenos; tamanho do lóbulo em relação ao filídio $1 / 3$.

7'. Trigônios grandes; tamanho do lóbulo em relação ao filídio 1/2-3/4.

8. Abertura do sinus ca. $45^{\circ}$......

8'. Abertura do sinus estreita.

9. Ápice do filídio obtuso; base decurrente; ápice plano; células lisas 4.9. C. unciloba

9'. Ápice do filídio agudo; base curva; ápice inflexo; mamilosas

4.1. C. acutangula 4.2. C. adnata 4.3. C. clausa 4.5. C. discoidea 4.7. C. rigidula 4.8. C. trifaria 4.4. C. comans

4.1. Cheilolejeunea acutangula (Nees) Grolle, J. Hattori Bot. Lab. 45: 173. 1979.

Fig. $46 \mathrm{~T}-\mathrm{Z}$

Gametófitos verde-claros a amarelados, medianos, ramos prostrados, ramificações tipo Lejeunea, hialoderme presente, merófito ventral 2-3(-4) células, lobos orbiculares, sobrepostos, ápice agudo, margem inteira, células clorofiladas, ápice inflexo, células isodiamétricas, lisas, trigônios grandes, oleocorpos homogêneos (agrupados), ocelos ausentes, lóbulos quadráticos a orbiculares, inflados, tamanho em relação ao filídio $1 / 4-1 / 6$, às vezes reduzidos, ápice do lóbulo involuto, dentes 1, papila hialina distal, anfigastros bífidos, sobrepostos, abertura do sinus ca. $45^{\circ}$, margem inteira, largura em relação ao caulídio 1-3x, base curva, quilhas do perianto 4, inteiras. Reprodução vegetativa ausente.

Material examinado: Minas Gerais, Conceição do Mato Dentro, O. Yano 501 (SP132045); Santana do Riacho, Serra da Bandeirinha, O. Yano \& Wanderley 10880, 10893, 10863 p.p. (SP220573; SP220586; SP220556); Câmara 1942 (SP419657); Dias Neto 271, 272 (SP419846; SP419847).

Associada a Marchantia chenopoda L., Kurzia capillaris (Sw.) Grolle, Jungermannia amoena Lindenb. \& Gottsche. Ocorre nos estados de AL, AM, BA, DF, ES, GO, MG, MS, MT, PA, PE, RJ, SC e SP. Na Serra do Cipó, cresce em tronco vivo e rocha.

4.2. Cheilolejeunea adnata (Kunze) Grolle, J. Bryol. 9: 529. 1977.

Fig. 47 A-E

Gametófitos verde-claros a amarelados, medianos, ramos prostrados, ramificações tipo Lejeunea, hialoderme presente, merófito ventral 2-3(-4) células, lobos orbiculares, ápice obtuso, margem com rizóides, células clorofiladas, ápice plano, células isodiamétricas, lisas, trigônios pequenos, oleocorpos homogêneos (agrupados), ocelos ausentes, lóbulos quadráticos a orbiculares, inflados, tamanho em relação ao filídio 1/4$1 / 6$, às vezes reduzidos, ápice do lóbulo plano, dentes 1 , papila hialina distal, anfigastros bífidos, espaçados, abertura do sinus estreita, margem inteira, largura em relação ao caulídio 1-3x, base reta, quilhas do perianto 4 , inteiras. Reprodução vegetativa por filídios caducos.

Material examinado: Minas Gerais, Santana do Riacho, Serra da Bandeirinha, O. Yano \& Wanderley 10898 (SP220591).

Ocorre nos estados de AC, AL, AM, AP, BA, CE, ES, MT, PA, PE, PR, RR, SC e SP. Na Serra do Cipó, cresce em tronco vivo.

4.3. Cheilolejeunea clausa (Nees \& Mont.) R.M. Schust., Hepat. Anthoc. N. Amer. 4: 863. 1980.

Fig. $47 \mathrm{~F}-\mathrm{I}$

Gametófitos verde-claros a amarelados, medianos, ramos prostrados, ramificações tipo Lejeunea, hialoderme presente, merófito ventral 2-3(4) células, lobos orbiculares, espaçados, ápice obtuso, margem inteira, células clorofiladas, ápice plano, células isodiamétricas, lisas, trigônios grandes, oleocorpos homogêneos (agrupados), ocelos ausentes, lóbulos quadráticos a orbiculares, inflados, tamanho em relação ao filídio $1 / 4-1 / 6$, às vezes reduzidos, ápice do lóbulo involuto, dentes 1 , papila hialina distal, anfigastros bífidos, espaçados, abertura do sinus estreita, margem inteira, largura em relação ao caulídio $1-3 x$, base curva, quilhas do perianto 4 , inteiras. Reprodução vegetativa por filídios caducos.

Material examinado: Minas Gerais, Santana do Riacho, Serra da Bandeirinha, O. Yano \& Wanderley 10831 (SP220524); Dias Neto 139a p.p. (SP419770).

Associada a Adelanthus carabayensis (Mont.) Grolle. Ocorre nos estados de AC, AL, AM, AP, BA, 

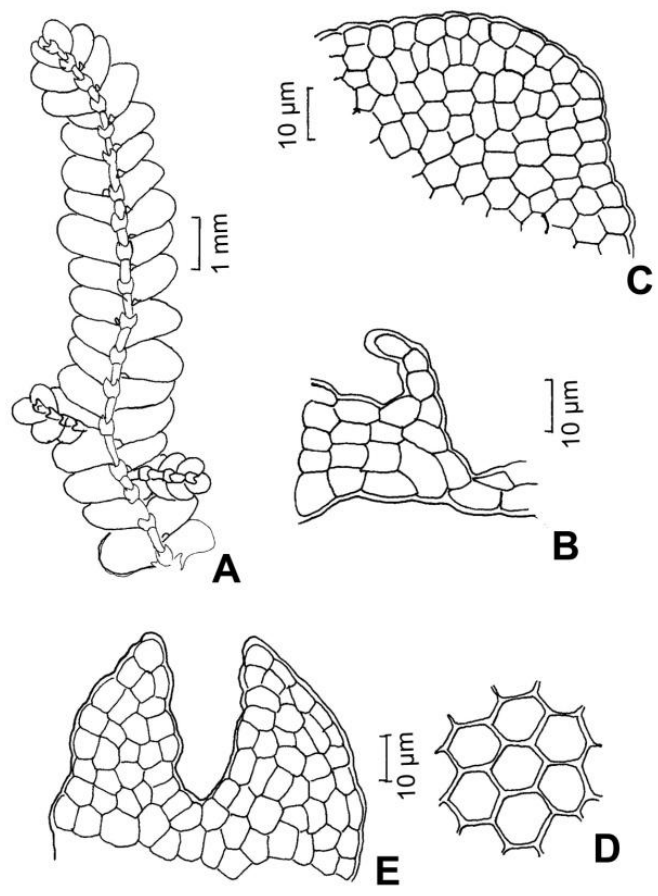

c
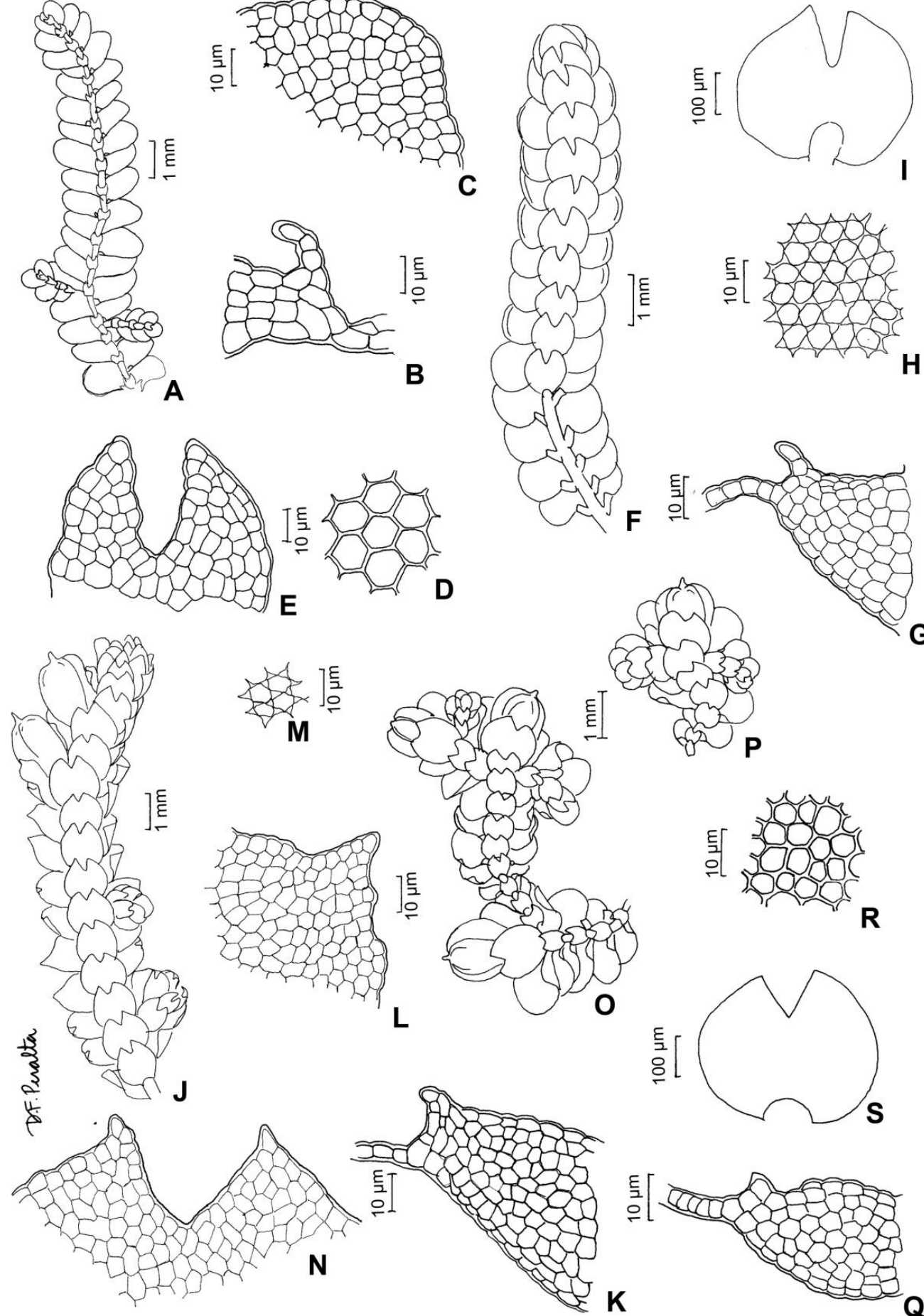

]$\frac{\varepsilon}{\varepsilon}$

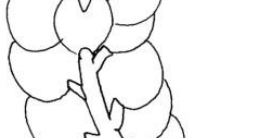

H
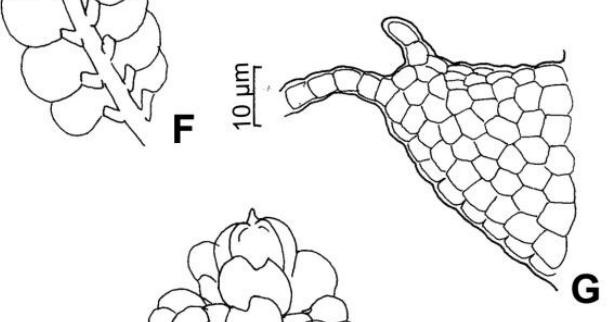

Fig. 47. Cheilolejeunea adnata (Kunze) Grolle. A. aspecto do gametófito. B. células do lóbulo do filídio. C. células da margem do filídio. D. células da lâmina do filídio. E. detalhe do anfigastro. Cheilolejeunea clausa (Nees \& Mont.) R.M. Schust. F. aspecto do gametófito. G. células do lóbulo do filídio. H. células da lâmina do filídio. I. anfigastro. Cheilolejeunea comans (Spruce) R.M. Schust. J. aspecto do gametófito. K. células do lóbulo do filídio. L. ápice do filídio. M. células da lâmina do filídio. N. detalhe do anfigastro. Cheilolejeunea discoidea (Lehm. \& Lindenb.) Kachroo \& R.M. Schust. O-P. aspecto do gametófito. Q. células do lóbulo do filídio. R. células da lâmina do filídio. S. anfigastro (A-E. O. Yano \& Wanderley 10898; F-I. O. Yano \& Wanderley 10831 ; J-N. O. Yano \& Wanderley 10868; O-S. O. Yano \& Wanderley 10622). 
CE, ES, GO, MG, MS, MT, PA, PE, PR, RJ, RS, SC e SP. Na Serra do Cipó, cresce em tronco vivo.

4.4. Cheilolejeunea comans (Spruce) R.M. Schust., Phytologia 45(5): 431. 1980.

Fig. $47 \mathrm{~J}-\mathrm{N}$

Gametófitos verde-claros a amarelados, pequenos, delicados, ramos prostrados, ramificações tipo Lejeunea, hialoderme presente, merófito ventral 46(8-10) células, lobos orbiculares, sobrepostos, ápice agudo, margem inteira, células clorofiladas, ápice inflexo, células isodiamétricas. Mamilosas, trigônios grandes, oleocorpos homogêneos (agrupados), ocelos ausentes, lóbulos claviformes, inflados, tamanho em relação ao filídio $1 / 4-1 / 6$, nunca reduzidos, ápice do lóbulo involuto, dentes 1, papila hialina distal, anfigastros bífidos, sobrepostos, abertura do sinus estreita, margem inteira, largura em relação ao caulídio 4-5x, base curva, quilhas do perianto 4 , inteiras. Reprodução vegetativa ausente.

Material examinado: Minas Gerais, Santana do Riacho, Serra da Bandeirinha, O. Yano \& Wanderley 10868 (SP220561); Dias Neto 195 (SP419806).

Ocorre nos estados de AM, BA, ES, PA, SC e SP. Na Serra do Cipó, cresce em rocha.

4.5. Cheilolejeunea discoidea (Lehm. \& Lindenb.) Kachroo \& R.M. Schust., J. Linn. Soc. London Bot. 56(368): 509. 1961.

Fig. 47 O-S

Gametófitos verde-claros a amarelados, pequenos, delicados, ramos prostrados, ramificações tipo Lejeunea, hialoderme presente, merófito ventral 46(8-10) células, lobos orbiculares, sobrepostos, ápice obtuso, margem inteira, células clorofiladas, ápice plano, células isodiamétricas, lisas, trigônios pequenos, oleocorpos homogêneos (agrupados), ocelos ausentes, lóbulos claviformes, inflados, tamanho em relação ao filídio $1 / 3$, nunca reduzidos, ápice do lóbulo plano, dentes 1, papila hialina distal, anfigastros bífidos, sobrepostos, abertura do sinus ca. $45^{\circ}$, margem inteira, largura em relação ao caulídio 1 $3 x$, base curva, quilhas do perianto 4 , inteiras. Reprodução vegetativa ausente.

Material examinado: Minas Gerais, Santana do Riacho, O. Yano \& Wanderley 10613 p.p., 10622, 10730 , 10746, 10782, 10785, 10890 (SP220308; SP220317; SP220424; SP220440; SP220475; SP220478; SP220583).

Associada a Sematophyllum subpinnatum (Brid.) E. Britton. Ocorre nos estados de AL, BA, CE, DF, ES, GO, MG, MS, MT, PA, RJ, RS, SE e SP. Na Serra do Cipó, cresce em tronco vivo.
4.6. Cheilolejeunea holostipa (Spruce) Grolle \& R.-L. Zhu in Grolle et al., Taxon 50: 1071. 2001. Fig. $48 \mathrm{~A}-\mathrm{C}$

Gametófitos verde-escuros a marrons, pequenos, delicados, ramos prostrados, ramificações tipo Lejeunea, hialoderme presente, merófito ventral 23(-4) células, lobos orbiculares, sobrepostos, ápice obtuso, margem inteira, células clorofiladas, ápice inflexo, células isodiamétricas, lisas, trigônios pequenos, oleocorpos segmentados, ocelos ausentes, lóbulos quadráticos a orbiculares, inflados, tamanho em relação ao filídio $1 / 2-3 / 4$, nunca reduzidos, ápice do lóbulo plano, dentes 1, papila hialina distal, anfigastros inteiros, espaçados, margem inteira, largura em relação ao caulídio 1-3x, base reta, quilhas do perianto 4, inteiras. Reprodução vegetativa ausente.

Material examinado: Minas Gerais, Congonhas do Norte, Pirani et al. 4150 p.p. (SP386336, SPF).

Associada a Sematophyllum subpinnatum (Brid.) E. Britton. Ocorre nos estados de AL, AM, BA, ES, MG, PA, PE, PR, RJ e SP. Na Serra do Cipó, cresce em folha de orquídea. Esta espécie era tratada anteriormente no gênero Cyrtolejeunea.

4.7. Cheilolejeunea rigidula (Mont.) R.M. Schust., Castanea 36: 102. 1971.

Fig. $48 \mathrm{D}-\mathrm{H}$

Gametófitos verde-claros a amarelados, medianos, ramos prostrados, ramificações tipo Lejeunea, hialoderme presente, merófito ventral 4-6(810) células, lobos orbiculares, sobrepostos, ápice obtuso, margem inteira, células clorofiladas, ápice plano, células isodiamétricas, lisas, trigônios grandes, oleocorpos homogêneos (agrupados), ocelos ausentes, lóbulos quadráticos a orbiculares, inflados, tamanho em relação ao filídio $1 / 2-3 / 4$ ou $1 / 3$, às vezes reduzidos, ápice do lóbulo involuto, dentes 1 , papila hialina distal, anfigastros bífidos, espaçados, abertura do sinus ca. $45^{\circ}$, margem inteira, largura em relação ao caulídio 1-3x, base curva, quilhas do perianto 4 , inteiras. Reprodução vegetativa ausente.

Material examinado: Minas Gerais, Santana do Riacho, Serra da Bandeirinha, O. Yano \& Wanderley 10770 p.p., 10787, 10859 p.p. (SP220464; SP220480; SP220552); Câmara et al. 2033 (SP419696); Dias Neto 226 (SP419822).

Associada a Cheilolejeunea unciloba (Lindenb.) Malombe, Lejeunea flava (Sw.) Nees e Plagiochila simplex (Sw.) Lindenb. Ocorre nos estados de AC, AL, AM, AP, BA, CE, DF, ES, GO, MG, MS, MT, PA, PB, $P E, P R, R J, R R, R S, S C, S E, S P$ e TO. Na Serra do Cipó, cresce em tronco vivo e caído. 

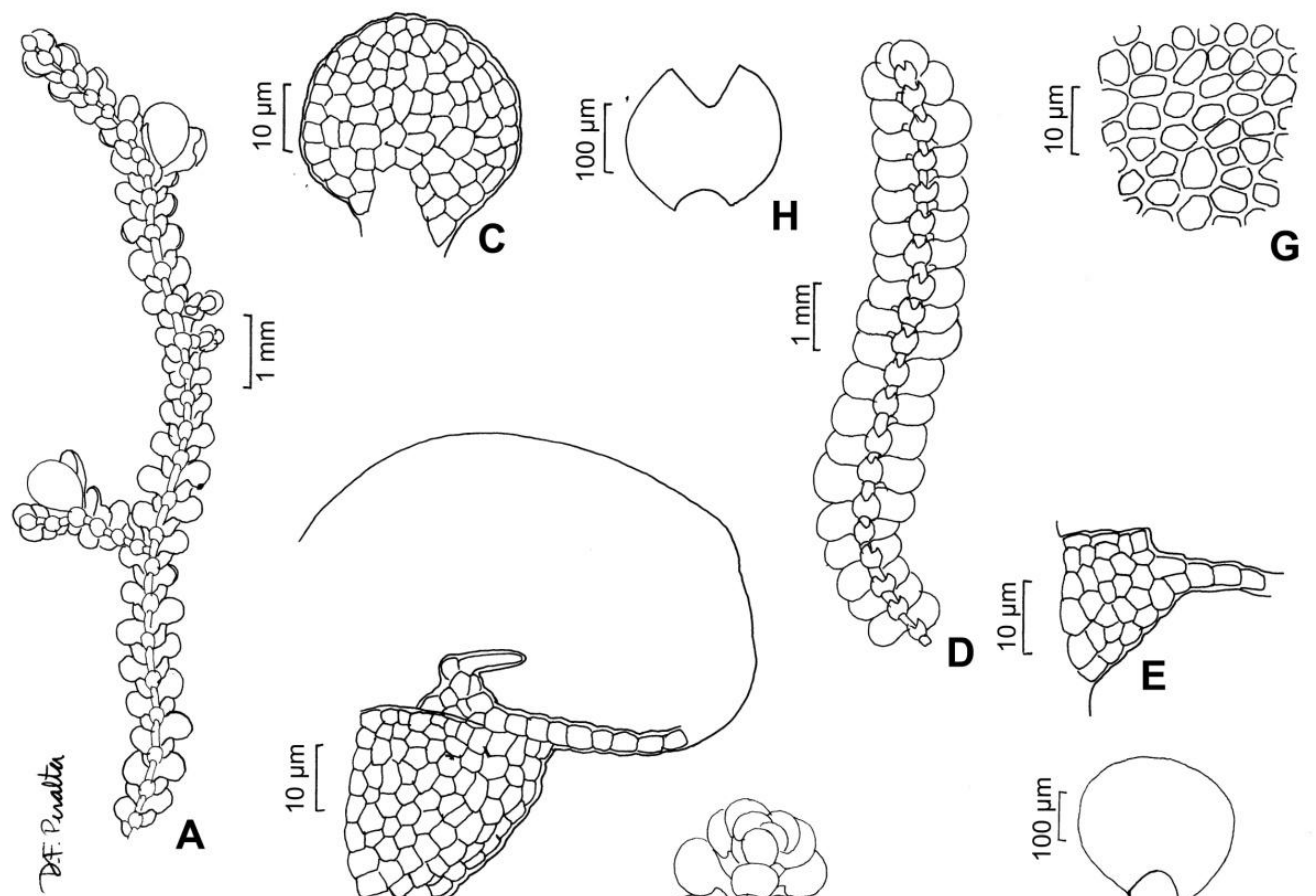

]$_{\ulcorner}^{\varepsilon}$<smiles>[CH]C</smiles>

G
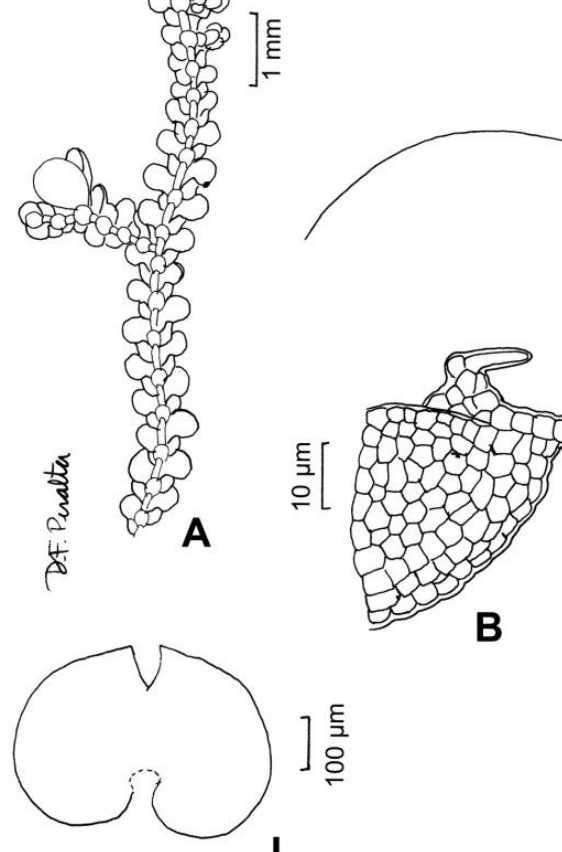

B

$\mathbf{L}$

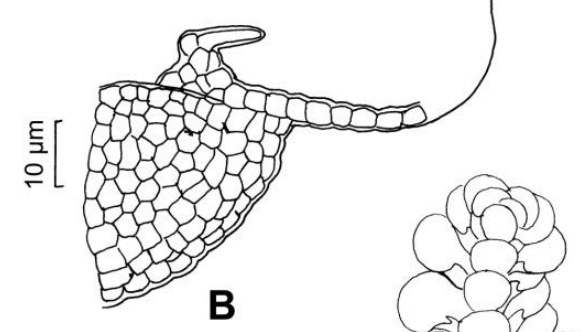

D
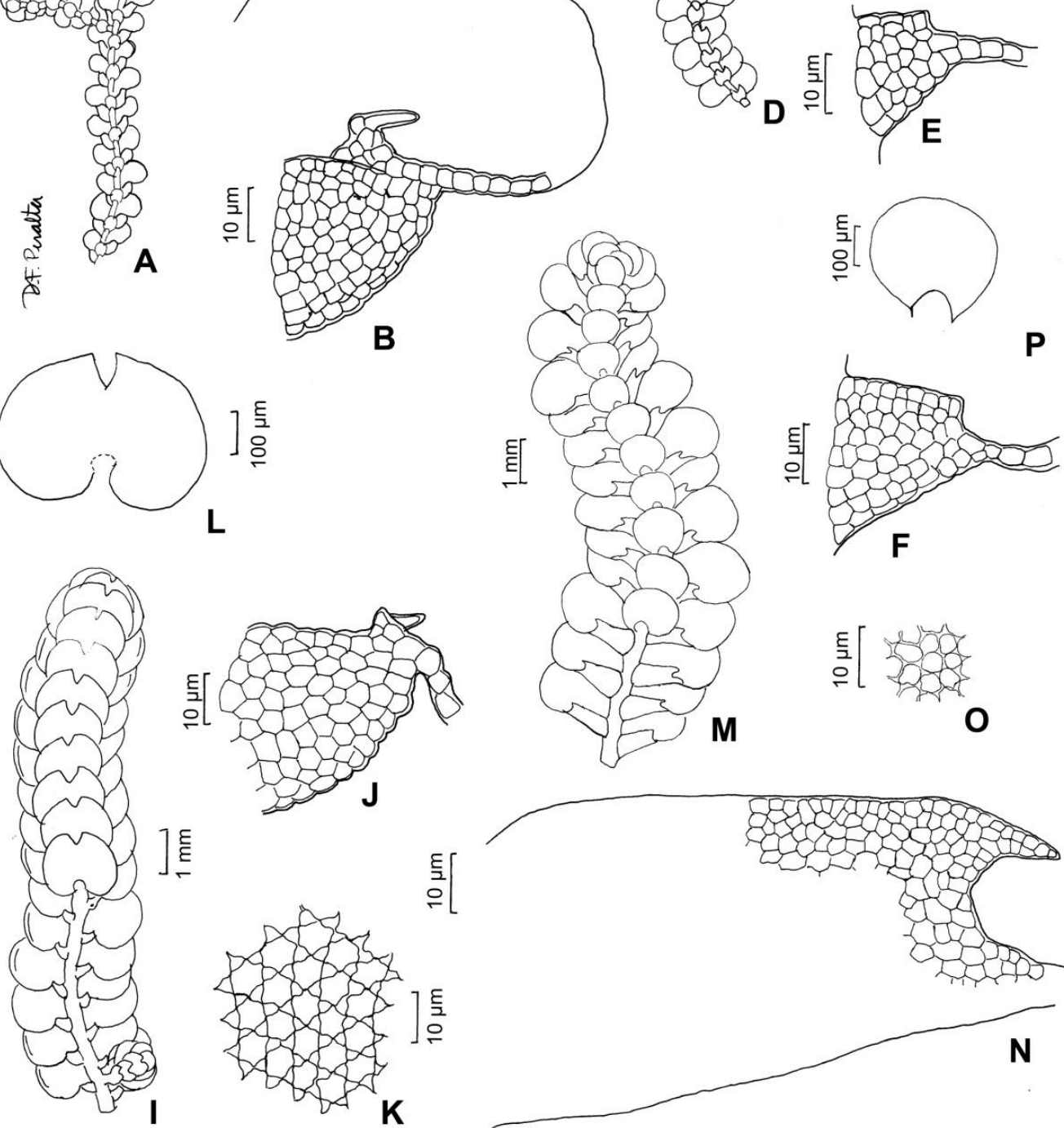

$\mathbf{P}$

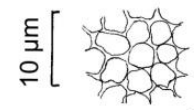

0
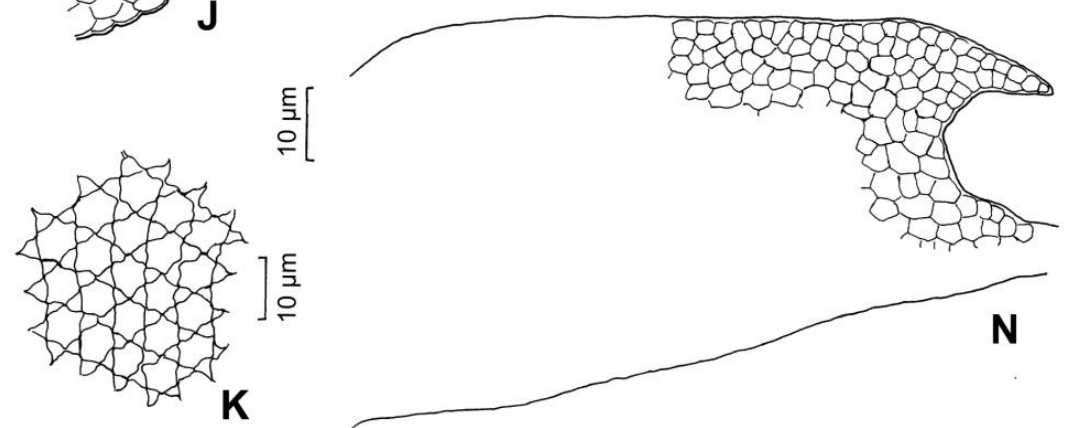

Fig. 48. Cheilolejeunea holostipa (Spruce) Grolle \& R.-L. Zhu. A. aspecto do gametófito. B. filídios com detalhe do lóbulo. C. anfigastro. Cheilolejeunea rigidula (Mont.) R.M. Schust. D. aspecto do gametófito. E-F. células do lóbulo do filídio. G. células da lâmina do filídio. H. anfigastro. Cheilolejeunea trifaria (Reinw. et al.) Mizut. I. aspecto do gametófito. J. células do lóbulo do filídio. K. células da lâmina do filídio. L. anfigastro. Cheilolejeunea unciloba (Lindenb.) Malombe. M. aspecto do gametófito. N. células do lóbulo do filídio. O. células da lâmina do filídio. P. anfigastro (A-C. Pirani et al. 4150 p.p.; D-H. O. Yano \& Wanderley 10770 p.p.; I-L. Pirani et al. 12298; M-P. O. Yano \& Wanderley 10788). 
4.8. Cheilolejeunea trifaria (Reinw. et al.) Mizut., J. Hattori Bot. Lab. 27: 132. 1964.

Fig. $48 \mathrm{I}-\mathrm{L}$

Gametófitos verde-claros a amarelados, medianos, ramos prostrados, ramificações tipo Lejeunea, hialoderme presente, merófito ventral 4-6(810) células, lobos orbiculares, sobrepostos, ápice obtuso, margem inteira, células clorofiladas, ápice plano, células isodiamétricas, lisas, trigônios grandes, oleocorpos homogêneos (agrupados), ocelos ausentes, lóbulos claviformes, inflados, tamanho em relação ao filídio 1/4-1/6, nunca reduzidos, ápice do lóbulo involuto, dentes 1, papila hialina distal, anfigastros bífidos, sobrepostos, abertura do sinus estreita, margem inteira, largura em relação ao caulídio 6-10x, base decurrente, quilhas do perianto 4 , inteiras. Reprodução vegetativa ausente.

Material examinado: Minas Gerais, Santana do Riacho, Pirani et al. 12298 (SP386342, SPF); Câmara 1959 (SP419671).

Ocorre nos estados do AC, AL, AM, AP, BA, CE, DF, ES, GO, MG, MS, MT, PA, PB, PI, PE, PR, RJ, RR e SP. Na Serra do Cipó, cresce em tronco vivo.

\subsection{Cheilolejeunea unciloba (Lindenb.)} Malombe, Acta Bot. Hung. 51(3-4): 325. 2009.

Fig. $48 \mathrm{M}-\mathrm{O}$

Gametófitos verde-claros a amarelados, medianos, ramos prostrados, ramificações tipo Lejeunea, hialoderme presente, merófito ventral 4-6(810) células, lobos orbiculares, sobrepostos, ápice obtuso, margem inteira, células clorofiladas, ápice inflexo, células isodiamétricas, lisas, trigônios pequenos, oleocorpos homogêneos (agrupados), ocelos ausentes, lóbulos claviformes, inflados, tamanho em relação ao filídio 1/2-3/4, nunca reduzidos, ápice do lóbulo involuto, dentes 1 , papila hialina distal, anfigastros inteiros, espaçados, margem inteira, largura em relação ao caulídio $4-5 x$, base curva, quilhas do perianto 4 , inteiras. Reprodução vegetativa ausente.

Material examinado: Minas Gerais, Santana do Riacho, Serra da Bandeirinha, O. Yano \& Wanderley 10788, 10823, 10839 p.p., 10874,10859 p.p. (SP220481; SP220516; SP220532; SP220567; SP220552).
Associada a Plagiochila simplex (Sw.) Lindenb., Cheilolejeunea rigidula (Mont.) R.M. Schust. e Sematophyllum subpinnatum (Brid.) E. Britton. Ocorre nos estados de AC, AM, BA, CE, ES, MG, PA, PE, RJ, RS, SC e SP. Na Serra do Cipó, cresce em tronco vivo e caído. Esta espécie era tratada anteriormente no gênero Leucolejeunea.

4.10. Cheilolejeunea xanthocarpa (Lehm. \& Lindenb.) Malombe, Acta Bot. Hung. 51(3-4): 326. 2009.

Fig. 49 A-C

Gametófitos verde-claros a amarelados, medianos, ramos prostrados, ramificações tipo Lejeunea, hialoderme presente, merófito ventral 4-6(810) células, lobos orbiculares, sobrepostos, ápice obtuso, margem inteira, células clorofiladas, ápice inflexo, células isodiamétricas, lisas, trigônios pequenos, oleocorpos homogêneos (agrupados), ocelos ausentes, lóbulos claviformes, inflados, tamanho em relação ao filídio 1/2-3/4, nunca reduzidos, ápice do lóbulo involuto, dentes 1 , papila hialina distal, anfigastros inteiros, sobrepostos, margem inteira, largura em relação ao caulídio $4-5 x$, base curva, quilhas do perianto 4, inteiras. Reprodução vegetativa ausente.

Material examinado: Minas Gerais, Santana do Riacho, Serra da Bandeirinha, O. Yano \& Wanderley 10803 p.p. (SP220496).

Associada a Frullania neesii Lindenb. Ocorre nos estados de AL, BA, CE, ES, GO, MG, PE, RJ, RS, $S C$ e SP. Na Serra do Cipó, cresce em tronco vivo. Esta espécie era tratada anteriormente no gênero Leucolejeunea.

\section{Cololejeunea (Spruce) Schiffn.}

Gametófitos verde-claros a amarelados, pequenos, delicados, ramos prostrados, ramificações tipo Lejeunea, hialoderme presente, merófito ventral 1 célula, lobos oblongo-lanceolados, espaçados, ápice agudo, margem crenulada ou inteira, células hialinas digitiformes presente ou não, ápice plano, células isodiamétricas, lisas, trigônios ausentes, oleocorpos segmentados, ocelos ausentes, papila hialina distal, anfigastros ausentes, quilhas do perianto 4 , inteiras. Reprodução vegetativa por gemas.

Chave para as espécies

1. Lobos oblongo-lanceolados; espaçados; ápice agudo; tamanho em relação ao filídio 1/4-1/6 5.1. C. cardiocarpa 1'. Lobos orbiculares; sobrepostos; ápice obtuso; tamanho em relação ao filídio 1/3..... 5.2. C. subcardiocarpa 
Flora da Serra do Cipó, Minas Gerais: Briófitas (Anthocerotophyta, Bryophyta e Marchantiophyta)

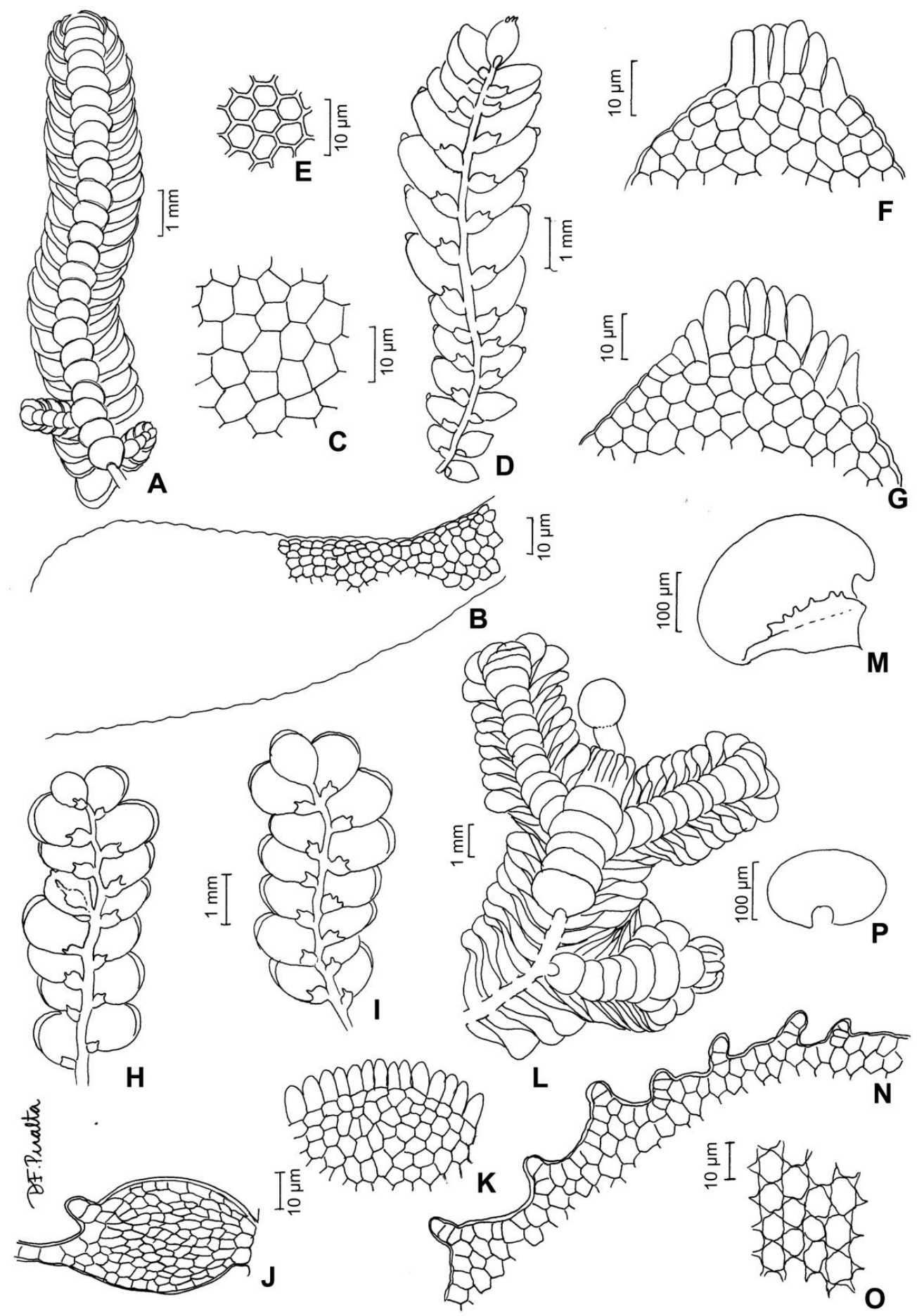

Fig. 49. Cheilolejeunea xanthocarpa (Lehm. \& Lindenb.) Malombe. A. aspecto do gametófito. B. células do lóbulo do filídio. C. células da lâmina do filídio. Cololejeunea cardiocarpa (Mont.) A. Evans. D. aspecto do gametófito. E. células da lâmina do filídio. F-G. ápice do filídio. Cololejeunea subcardiocarpa P. Tixier. H-I. aspecto do gametófito. J. células do lóbulo do filídio. K. ápice do filídio. Frullanoides tristis (Steph.) van Slageren. L. aspecto do gametófito. M. filídio. n. células da margem do lóbulo do filídio. O. células da lâmina do filídio. P. anfigastro (A-C. O. Yano \& Wanderley 10803 p.p.; D-G. O. Yano \& Wanderley 10813; H-K. O. Yano \& Wanderley 10814; L-P. O. Yano \& Wanderley 10615). 
5.1. Cololejeunea cardiocarpa (Mont.) A. Evans, Mem. Torrey Bot. Club 8: 172. 1902.

Fig. 49 D-G

Gametófitos verde-claros a amarelados, pequenos, delicados, ramos prostrados, ramificações tipo Lejeunea, hialoderme presente, merófito ventral 1 célula, lobos oblongo-lanceolados, espaçados, ápice agudo, margem crenulada, células hialinas digitiformes, ápice plano, células isodiamétricas, lisas, trigônios ausentes, oleocorpos segmentados, ocelos ausentes, lóbulos quadráticos a orbiculares, inflados, tamanho em relação ao filídio $1 / 4-1 / 6$, às vezes reduzidos, ápice do lóbulo involuto, dentes 1, papila hialina distal, anfigastros ausentes, quilhas do perianto 4 , inteiras. Reprodução vegetativa por gemas.

Material examinado: Minas Gerais, Santana do Riacho, Serra da Bandeirinha, O. Yano \& Wanderley 10813 (SP220506).

Ocorre nos estados de AL, AM, AP, BA, ES, GO, MG, MS, MT, PA, PB, PE, PR, RJ, RO, RR, SC, SE e SP. Na Serra do Cipó, cresce em folha. Esta espécie é facilmente identificada pois é comumente encontrada como epifila, o formato do filídio é oblongo e o número reduzido de células hialinas no ápice é característico.

5.2. Cololejeunea subcardiocarpa P. Tixier, Bradea 3(6): 39. 1980.

Fig. $49 \mathrm{H}-\mathrm{K}$

Gametófitos verde-claros a amarelados, pequenos, delicados, ramos prostrados, ramificações tipo Lejeunea, hialoderme presente, merófito ventral 1 célula, lobos orbiculares, sobrepostos, ápice obtuso, margem crenulada, células hialinas digitiformes, ápice plano, células isodiamétricas, lisas, trigônios ausentes, oleocorpos segmentados, ocelos ausentes, lóbulos quadráticos a orbiculares, inflados, tamanho em relação ao filídio $1 / 3$, às vezes reduzidos, ápice do lóbulo involuto, dentes 1, papila hialina distal, anfigastros ausentes, quilhas do perianto 4 , inteiras. Reprodução vegetativa ausente.

Material examinado: Minas Gerais, Santana do Riacho, Serra da Bandeirinha, O. Yano \& Wanderley 10814 (SP220507).

Ocorre nos estados de AC, AL, AM, BA, CE, ES, GO, MG, MT, PA, PE, PR, RJ e SP. Na Serra do
Cipó, cresce em folha. Esta espécie possui uma grande porção da margem do filídio coberta por células hialinas.

\section{Frullanoides Raddi}

Gametófitos verde-escuros a marrons, medianos, ramos ascendentes ou pêndulos, tipo Frullania, hialoderme presente, merófito ventral 2030(-40) células, lobos orbiculares, sobrepostos, ápice obtuso, margem inteira, células isodiamétricas, lisas, trigônios grandes, oleocorpos segmentados, ocelos ausentes, papila hialina proximal, anfigastros inteiros, sobrepostos, margem inteira, largura em relação ao caulídio 4-5x, base auriculada, perianto pluriplicado, inteiras. Reprodução vegetativa ausente.

6.1. Frullanoides tristis (Steph.) van Slageren, Meded. Bot. Mus. Herb. Utrech 544: 110. 1985.

Fig. 49 L-P

Gametófitos verde-escuros a marrons, medianos, ramos ascendentes ou pêndulos, tipo Frullania, hialoderme presente, merófito ventral 2030(-40) células, lobos orbiculares, sobrepostos, ápice obtuso, margem inteira, células clorofiladas, ápice plano, células isodiamétricas, lisas, trigônios grandes, oleocorpos segmentados, ocelos ausentes, lóbulos claviformes, aplainados, tamanho em relação ao filídio $1 / 3$, nunca reduzidos, ápice do lóbulo plano, dentes 5 ou 8 , papila hialina proximal, anfigastros inteiros, sobrepostos, margem inteira, largura em relação ao caulídio 4-5x, base auriculada, perianto pluriplicado, inteiras. Reprodução vegetativa ausente.

Material examinado: Minas Gerais, Santana do Riacho, O. Yano \& Wanderley 10615 (SP220310).

Ocorre nos estados de BA, ES, GO, PE, SE e SP. Na Serra do Cipó, cresce em tronco vivo.

\section{Lejeunea Lib.}

Gametófitos pequenos. Filídios com lobos planos, ápice rômbico até obtuso, margem inteira ou às vezes crenulada, nunca denteada, lóbulos pequenos, às vezes reduzidos, ovados, dente apical curto; células regulares; parede celular delgada, às vezes com pequenos trigônios, anfigastros bífidos, margem inteira. 
1. Merófito ventral 2-3(-4) células.

2. Trigônios ausentes

7.4. L. laetevirens

2'. Trigônios pequenos . 7.6. L. ptosimophylla

1'. Merófito ventral 4-6(8-10) células.

3. Trigônios pequenos.

4. Tamanho em relação ao filídio 1/2-3/4.

4'. Tamanho em relação ao filídio 1/4-1/6

3'. Trigônios ausentes.

5. Inserção do anfigastro reta

5 '. Inserção do anfigastro curva.

6. Ápice do lóbulo plano; reprodução vegetativa por filídios caducos

6 '. Ápice do lóbulo involuto; reprodução vegetativa ausente

7.1. Lejeunea deplanata Nees in Gottsche, Lindenb \& Nees, Syn. Hepat.: 368. 1845.

Fig. $50 \mathrm{R}-\mathrm{V}$

Gametófitos verde-claros a amarelados, pequenos, delicados, ramos prostrados, ramificações tipo Lejeunea, hialoderme presente, merófito ventral 46(8-10) células, lobos orbiculares, sobrepostos, ápice obtuso, margem inteira, células clorofiladas, ápice plano, células isodiamétricas, lisas, trigônios ausentes, oleocorpos segmentados, ocelos ausentes, lóbulos quadráticos a orbiculares, inflados, tamanho em relação ao filídio 1/4-1/6, às vezes reduzidos, ápice do lóbulo plano, dentes 1, papila hialina proximal, anfigastros bífidos, espaçados, abertura do sinus ca. $45^{\circ}$, margem inteira, largura em relação ao caulídio 1 $3 x$, base reta, quilhas do perianto 5 , inteiras. Reprodução vegetativa por filídios caducos.

Material examinado: Minas Gerais, Santana do Riacho, Serra da Bandeirinha, O. Yano \& Wanderley 10807 p.p., 10858, 10876, 10919 (SP220500; SP220551; SP220569; SP220612); Câmara 2006 p.p. (SP419689).

Associada a Microlejeunea bullata (Taylor) Steph. e H. epiphylla Bischler. Ocorre nos estados de AM, BA, CE, ES, GO, MS, MT, PB, RJ, RS e SP. Na Serra do Cipó, cresce em tronco vivo e solo.

7.2. Lejeunea flava (Sw.) Nees, Naturgesch. Eur. Leberm. 3: 277. 1838.

Fig. $50 \mathrm{~A}-\mathrm{E}$

Gametófitos verde-claros a amarelados, medianos, ramos prostrados, ramificações tipo Lejeunea, hialoderme presente, merófito ventral 4-6(810) células, lobos orbiculares, sobrepostos, ápice obtuso, margem inteira, células clorofiladas, ápice plano, células isodiamétricas, lisas, trigônios pequenos, oleocorpos segmentados, ocelos ausentes, lóbulos quadráticos a orbiculares, inflados, tamanho em relação ao filídio 1/4-1/6, às vezes reduzidos, ápice do lóbulo plano, dentes 1 , papila hialina proximal, anfigastros bífidos, sobrepostos, abertura do sinus ca. $45^{\circ}$, margem inteira, largura em relação ao caulídio 4$5 x$, base curva, quilhas do perianto 5 , inteiras. Reprodução vegetativa ausente.
Material examinado: Minas Gerais, Conceição do Mato Dentro, Vital 1251 (SP87132); Itambé do Mato Dentro, Vital 7614, 7627 (SP132838; SP132832); Jaboticatubas, Pirani et al. 6296 p.p. (SP432416, SPF); Santana do Riacho, O. Yano \& Wanderley 10719, 10745, 10770 p.p., 10779, 10798, 10756, 10818 p.p., 10846, 10855, 10878 p.p. (SP220414; SP220439; SP220464; SP220472; SP220491; SP220450; SP220511; SP220539; SP220548; SP220571); Câmara 1986 p.p. (SP419682).

Associada a Cheilolejeunea rigidula (Mont.) R.M. Schust., Metzgeria ciliata Raddi, Radula quadrata Gottsche, Sematophyllum subpinnatum (Brid.) E. Britton e Syrrhopodon prolifer Schwägr. Ocorre nos estados de AC, AL, AM, BA, CE, DF, ES, FN, GO, MG, MS, MT, PA, PB, PE, PR, RJ, RR, RS, SC, SE, $\mathrm{SP}$ e TO. Na Serra do Cipó, cresce em tronco vivo, solo e folhas. Esta é a espécie mais comum e facilmente identificada do gênero pela combinação da coloração verde-amarelada, células do filídio verrucosas e a abertura do sinus em formato de $U$.

7.3. Lejeunea laeta (Lehm. \& Lindenb.) Gottsche et al., Syn. Hepat.: 380. 1845.

Fig. $50 \mathrm{~F}-\mathrm{L}$

Gametófitos verde-claros a amarelados, pequenos, delicados, ramos prostrados, ramificações tipo Lejeunea, hialoderme presente, merófito ventral 46(8-10) células, lobos orbiculares, sobrepostos, ápice obtuso, margem inteira, células clorofiladas, ápice plano, células isodiamétricas, lisas, trigônios ausentes, oleocorpos segmentados, ocelos ausentes, lóbulos quadráticos a orbiculares, inflados, tamanho em relação ao filídio $1 / 4-1 / 6$, às vezes reduzidos, ápice do lóbulo involuto, dentes 1, papila hialina proximal, anfigastros bífidos, espaçados, abertura do sinus ca. $45^{\circ}$, margem inteira, largura em relação ao caulídio 1$3 x$, base curva, quilhas do perianto 5 , inteiras. Reprodução vegetativa ausente.

Material examinado: Minas Gerais, Santana do Riacho, Dias Neto 227 (SP419823).

Ocorre nos estados da BA, CE, MG, RJ e SP. Na Serra do Cipó, cresce em tronco vivo. 

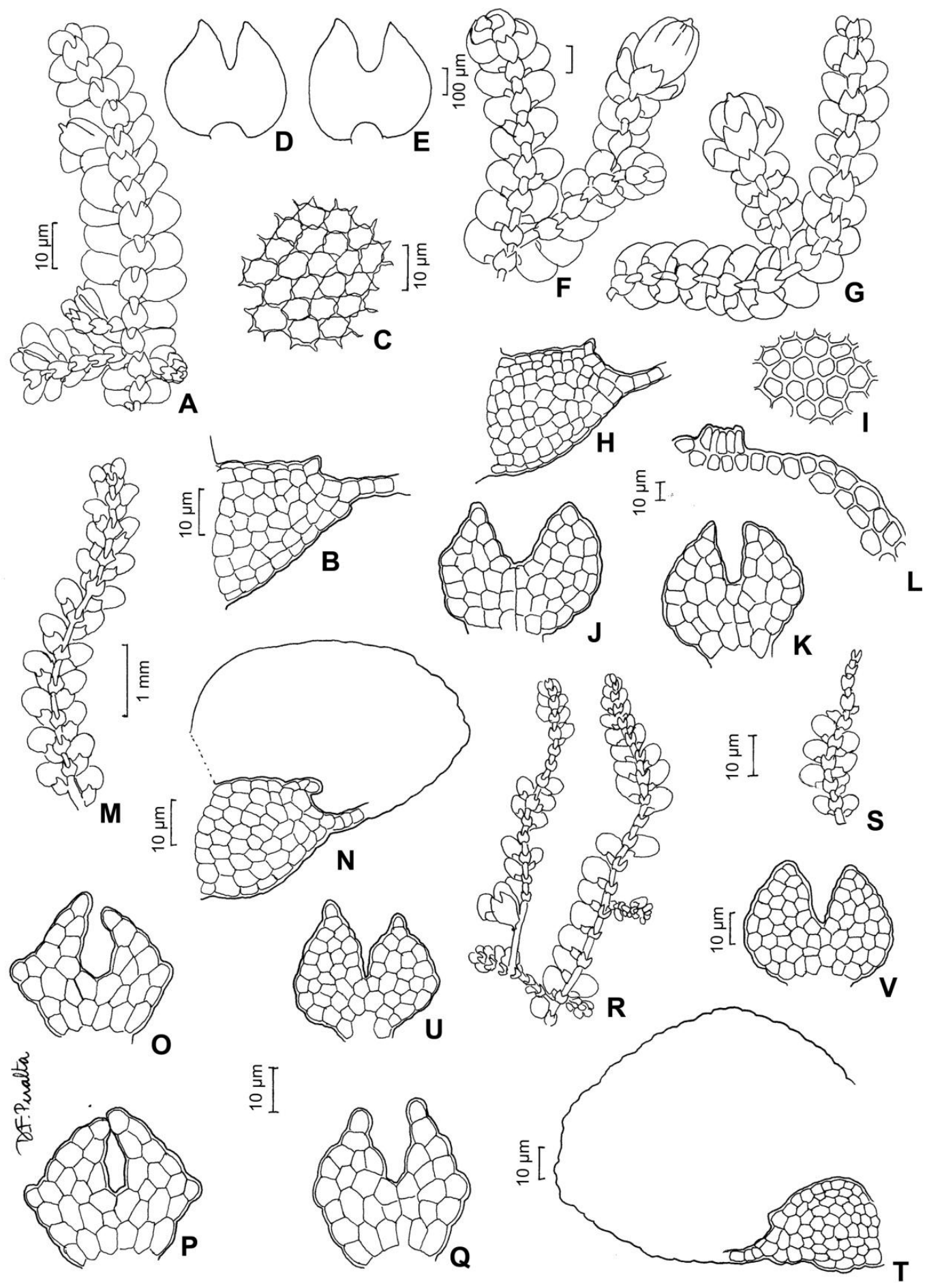

Fig. 50. Lejeunea flava (Sw.) Nees. A. aspecto do gametófito. B. células do lóbulo do filídio. C. células da lâmina do filídio. D-E. anfigastros. Lejeunea laeta (Lehm. \& Lindenb.) Gottsche et al. F-G. aspecto do gametófito. H. células do lóbulo do filídio. I. células da lâmina do filídio. J-K. anfigastros. L. ápice do perianto. Lejeunea laetevirens Nees \& Mont. M. aspecto do gametófito. N. células do lóbulo do filídio. O-Q. anfigastros. Lejeunea deplanata Nees in Gottsche. R-S. aspecto do gametófito. T. células do lóbulo do filídio. U-V. anfigastros (A-E. Vital 1251; F-L. Dias Neto 227; M-Q. O. Yano \& Wanderley 10747; R-V. O. Yano \& Wanderley 10858). 
Flora da Serra do Cipó, Minas Gerais: Briófitas (Anthocerotophyta, Bryophyta e Marchantiophyta)

7.4. Lejeunea laetevirens Nees \& Mont. in Ramón de la Sagra, Hist. Phys. Bot. Plant. Cell. Cuba 9: 469. 1842.

Fig. $50 \mathrm{M}-\mathrm{Q}$

Gametófitos verde-claros a amarelados, pequenos, delicados, ramos prostrados, ramificações tipo Lejeunea, hialoderme presente, merófito ventral 23(-4) células, lobos orbiculares, espaçados, ápice obtuso, margem inteira, células clorofiladas, ápice plano, células isodiamétricas, rugosas, trigônios ausentes, oleocorpos segmentados, ocelos ausentes, lóbulos quadráticos a orbiculares, inflados, tamanho em relação ao filídio $1 / 2-3 / 4$, nunca reduzidos, ápice do lóbulo plano, dentes 1, papila hialina proximal, anfigastros bífidos, espaçados, abertura do sinus ca. $45^{\circ}$, margem dois dentes laterais, largura em relação ao caulídio 1-3x, base curva, quilhas do perianto 5, inteiras. Reprodução vegetativa ausente.

Material examinado: Minas Gerais, Santana do Riacho, O. Yano \& Wanderley 10747, 10872, 10903 p.p. (SP220441; SP220565; SP220596); Dias Neto 98 (SP419736).

Associada a Frullania neesii Lindenb. Ocorre nos estados de AC, AL, AM, AP, BA, CE, DF, ES, FN, GO, MG, MS, MT, PA, PB, PE, RJ, RR, RS, SC, SE e SP. Na Serra do Cipó, cresce em tronco vivo. Esta é uma espécie caracterizada pelo hábito delicado e facilmente identificada pelas células do filídio verrucosas e os dentes laterais no anfigastro.

7.5. Lejeunea phyllobola Nees \& Mont. in Ramón de la Sagra, Hist. Fis. Pol. Natur. Bot. Cuba 9: 471. 1842.

\section{Fig. $51 \mathrm{~A}-\mathrm{E}$}

Gametófitos verde-claros a amarelados, pequenos, delicados, ramos prostrados, ramificações tipo Lejeunea, hialoderme presente, merófito ventral 46(8-10) células, lobos orbiculares, sobrepostos, ápice obtuso, margem inteira, células clorofiladas, ápice plano, células isodiamétricas, lisas, trigônios ausentes, oleocorpos segmentados, ocelos ausentes, lóbulos quadráticos a orbiculares, inflados, tamanho em relação ao filídio 1/4-1/6, às vezes reduzidos, ápice do lóbulo plano, dentes 1, papila hialina proximal, anfigastros bífidos, espaçados, abertura do sinus ca. $45^{\circ}$, margem inteira, largura em relação ao caulídio 1 -
$3 x$, base curva, quilhas do perianto 5 , inteiras. Reprodução vegetativa por filídios caducos.

Material examinado: Minas Gerais, Conceição do Mato Dentro, O. Yano 488 p.p. (SP132041); Santana do Riacho, Serra da Bandeirinha, O. Yano \& Wanderley 10887, 10926 (SP220580; SP220619).

Associada a Calliscostella pallida (Hornsch.) Ångstr. Ocorre nos estados de AC, AL, AM, BA, CE, DF, ES, GO, MG, MS, MT, PA, RJ, RS, SC e SP. Na Serra do Cipó, cresce em rocha, solo e tronco vivo.

7.6. Lejeunea ptosimophylla C. Massal., Nuevo Giorn. Bot. Ital. 13: 123. 1881.

Fig. 51 F-K

Gametófitos verde-claros a amarelados, pequenos, delicados, ramos prostrados, ramificações tipo Lejeunea, hialoderme presente, merófito ventral 2$3(-4)$ células, lobos orbiculares, sobrepostos, ápice obtuso, margem inteira, células clorofiladas, ápice plano, células isodiamétricas, lisas, trigônios pequenos, oleocorpos segmentados, ocelos ausentes, lóbulos quadráticos a orbiculares, aplainados, tamanho em relação ao filídio $1 / 4-1 / 6$, às vezes reduzidos, ápice do lóbulo plano, dentes 1, papila hialina proximal, anfigastros bífidos, espaçados, abertura do sinus ca. $45^{\circ}$, margem inteira, largura em relação ao caulídio $1-3 x$, base curva, quilhas do perianto 5, inteiras. Reprodução vegetativa por filídios caducos.

Material examinado: Minas Gerais, Santana do Riacho, O. Yano \& Wanderley 10924 (SP220617).

Ocorre nos estados da BA e ES. Na Serra do Cipó, cresce em tronco vivo.

\section{Lopholejeunea (Spruce) Schiffn.}

Gametófitos pretos, pequenos, delicados, ramificações tipo Lejeunea, hialoderme presente, lobos orbiculares, sobrepostos, ápice obtuso, margem inteira, células clorofiladas, ápice plano, células isodiamétricas, lisas, trigônios pequenos, oleocorpos segmentados, ocelos ausentes, papila hialina proximal, anfigastros inteiros, espaçados, margem inteira, base curva, quilhas do perianto 4, laciniadas, reprodução vegetativa ausente. 

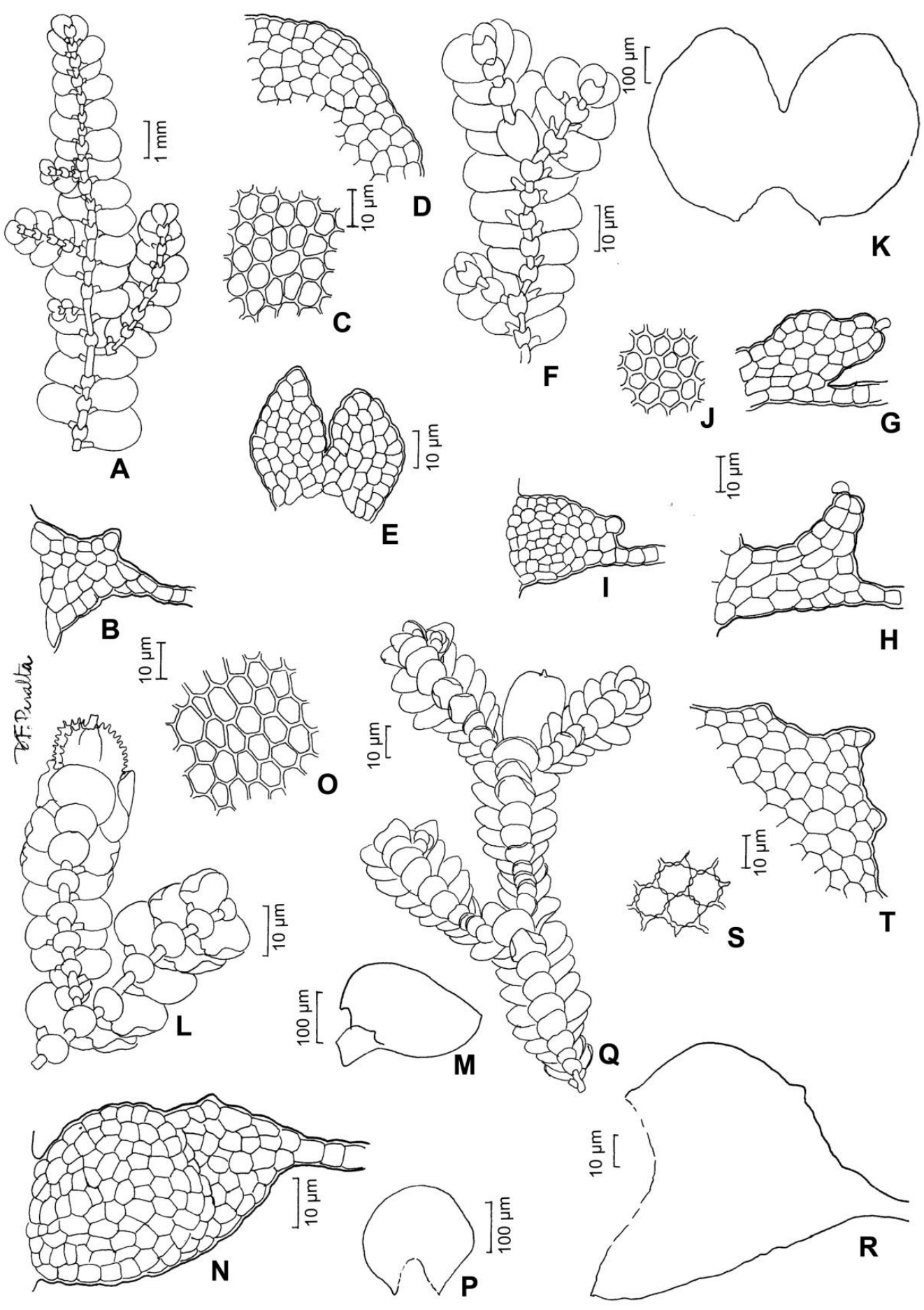

Fig. 51. Lejeunea phyllobola Nees \& Mont. A. aspecto do gametófito. B. células do lóbulo do filídio. C. células da lâmina do filídio. D. células da margem do filídio. E. anfigastro. Lejeunea ptosimophylla C. Massal. F. aspecto do gametófito. G-I. células do lóbulo do filídio. J. células da lâmina do filídio. K. anfigastro. Lopholejeunea nigricans (Lindenb.) Schiffn. L. aspecto do gametófito. M. filídio. N. células do lóbulo do filídio. O. células da lâmina do filídio. $\mathrm{P}$. anfigastro. Marchesinia brachiata (Sw.) Schiffn. Q. aspecto do gametófito. R. detalhe do lóbulo do filídio. S. células da lâmina do filídio. T. células do ápice do filídio (AE. O. Yano \& Wanderley 10887; F-K. O. Yano \& Wanderley 10924; L-P. O. Yano \& Wanderley 10845 p.p.; Q-T. Prado s.n. p.p.). 
Flora da Serra do Cipó, Minas Gerais: Briófitas (Anthocerotophyta, Bryophyta e Marchantiophyta)

8.1. Lopholejeunea nigricans (Lindenb.) Schiffn., Consp. Hepat. Archip. Ind.: 293. 1898.

Fig. $51 \mathrm{~L}-\mathrm{P}$

\begin{abstract}
Gametófitos pretos, pequenos, delicados, ramos prostrados, ramificações tipo Lejeunea, hialoderme presente, merófito ventral 4-6(8-10) células, lobos orbiculares, sobrepostos, ápice obtuso, margem inteira, células clorofiladas, ápice plano, células isodiamétricas, lisas, trigônios pequenos, oleocorpos segmentados, ocelos ausentes, lóbulos claviformes, inflados, tamanho em relação ao filídio $1 / 3$, nunca reduzidos, ápice do lóbulo involuto, dentes 1, papila hialina proximal, anfigastros inteiros, espaçados, margem inteira, largura em relação ao caulídio $1-3 x$, base curva, quilhas do perianto 4 , laciniadas, reprodução vegetativa ausente.
\end{abstract}

Material examinado: Minas Gerais, Santana do Riacho, O. Yano \& Wanderley 10845 p.p. (SP220538).

Associada a Porotrichum longirostre (Hook.) Mitt. e Plagiochila rutilans Lindenb. Ocorre nos estados de AC, AM, BA, CE, DF, ES, GO, MG, MS, MT, PA, PE, PR, RJ, RS, SC e SP. Na Serra do Cipó, cresce em tronco vivo. Esta espécie possui uma coloração preta brilhante muito característica e facilmente identificável. Possui ainda como característica diagnóstica o anfigastro que não cobre o perianto.

\section{Marchesinia A. Gray}

Gametófitos verde-escuros a marrons, medianos, ramos ascendentes ou pêndulos, tipo Frullania, hialoderme presente, lobos orbiculares, sobrepostos, ápice agudo, margem inteira, células clorofiladas, ápice plano ou inflexo, células isodiamétricas, lisas, trigônios pequenos, oleocorpos segmentados, ocelos ausentes, papila hialina proximal, anfigastros inteiros, sobrepostos ou espaçados, margem inteira, base decurrente, quilhas do perianto não diferenciadas, inteiras, perianto aplainado. Reprodução vegetativa ausente.

9.1. Marchesinia brachiata (Sw.) Schiffn. in Engler \& Prantl, Natürl. Pflanzenfam. 1(3): 128. 1893.

Fig. $51 \mathrm{Q}-\mathrm{T}$

Gametófitos verde-escuros a marrons, medianos, ramos ascendentes ou pêndulos, tipo Frullania, hialoderme presente, merófito ventral 20$30(-40)$ células, lobos orbiculares, sobrepostos, ápice agudo, margem inteira, células clorofiladas, ápice plano ou inflexo, células isodiamétricas, lisas, trigônios pequenos, oleocorpos segmentados, ocelos ausentes, lóbulos quadráticos a orbiculares, inflados, tamanho em relação ao filídio $1 / 3$, às vezes reduzidos, ápice do lóbulo plano, dentes 2, papila hialina proximal, anfigastros inteiros, sobrepostos ou espaçados, margem inteira, largura em relação ao caulídio 1-3x, base decurrente, quilhas do perianto não diferenciadas, inteiras, perianto aplainado. Reprodução vegetativa ausente.

Material examinado: Minas Gerais, Santana do Riacho, Serra da Bandeirinha, Prado s.n. p.p. (SP220630).

Associada a Metzgeria conjugata Lindb. Ocorre nos estados de BA, CE, ES, MG, PE, PR, RJ, RR, SC, SE e SP. Na Serra do Cipó, cresce em tronco vivo. Esta espécie apresenta o hábito dicotômico facilmente visualizado.

\section{Mastigolejeunea (Spruce) Schiffn.}

Gametófitos verde-escuros a marrons, medianos, ramificações tipo Lejeunea, hialoderme presente, lobos orbiculares, sobrepostos, ápice obtuso, margem inteira, células clorofiladas, ápice plano, células mais longas que largas, lisas, trigônios grandes, oleocorpos segmentados, ocelos ausentes, papila hialina proximal, anfigastros inteiros, sobrepostos, margem inteira, quilhas do perianto 3 , inteiras. Reprodução vegetativa ausente.

10.1. Mastigolejeunea auriculata (Wilson) Schiffn. in Engler \& Prantl, Natürl. Pflanzenfam. 1(3): 129. 1893.

Fig. $52 \mathrm{~A}-\mathrm{F}$

Gametófitos verde-escuros a marrons, medianos, ramos prostrados ou ascendentes ou pêndulos, ramificações tipo Lejeunea, hialoderme presente, merófito ventral 20-30(-40) células, lobos orbiculares, sobrepostos, ápice obtuso, margem inteira, células clorofiladas, ápice plano, células mais longas que largas, lisas, trigônios grandes, oleocorpos segmentados, ocelos ausentes, lóbulos claviformes, inflados, tamanho em relação ao filídio $1 / 4-1 / 6$, nunca reduzidos, ápice do lóbulo plano, dentes 1 , papila hialina proximal, anfigastros inteiros, sobrepostos, margem inteira, largura em relação ao caulídio $4-5 x$, base curva, quilhas do perianto 3 , inteiras. Reprodução vegetativa ausente.

Material examinado: Minas Gerais, Santana do Riacho, Serra da Bandeirinha, O. Yano \& Wanderley 10732 (SP220426).

Ocorre nos estados de AC, AM, AP, BA, CE, DF, ES, GO, MG, MS, MT, PA, PR, RJ, RO, RS, SP e TO. Na Serra do Cipó, cresce em tronco vivo. Esta espécie apresenta o hábito dos filídios quando secos muito imbricados, contrastando com o aspecto úmido. 


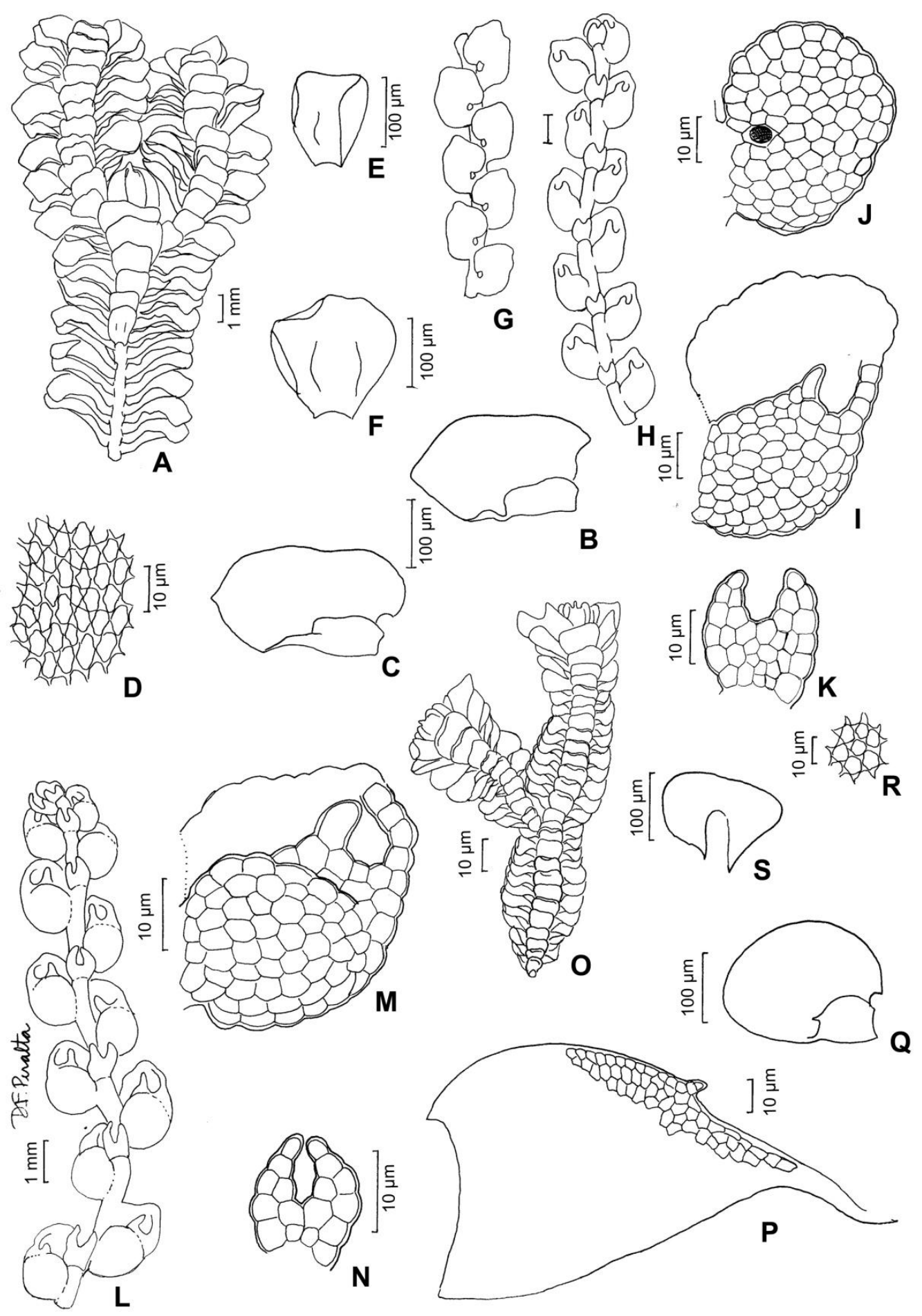

Fig. 52. Mastigolejeunea auriculata (Wilson) Schiffn. A. aspecto do gametófito. B-C. filídios. D. células da lâmina do filídio. E-F. anfigastros. Microlejeunea bullata (Taylor) Steph. G-H. aspecto do gametófito. I. células do lóbulo do filídio. J. visão dorsal do filidio, mostrando ocelo. K. anfigastro. Microlejeunea epiphylla Bischler. L. aspecto do gametófito. M. células do lóbulo do filídio. N. anfigastro. Schiffneriolejeunea polycarpa (Nees) Gradst. O. aspecto do gametófito. P. células do lóbulo do filídio. Q. filídio. R. células da lâmina do filídio. S. anfigastro (A-F. O. Yano \& Wanderley 10732; G-K. Câmara 2006 p.p.; L-N. O. Yano \& Wanderley 10807 p.p.; O-S. O. Yano \& Wanderley 10735). 
Flora da Serra do Cipó, Minas Gerais: Briófitas (Anthocerotophyta, Bryophyta e Marchantiophyta)

\section{Microlejeunea Steph.}

Gametófitos verde-claros a amarelados, pequenos, delicados, ramificações tipo Lejeunea, hialoderme presente, lobos orbiculares, espaçados, ápice obtuso, margem inteira, células clorofiladas, ápice plano, células isodiamétricas, lisas, trigônios pequenos, oleocorpos segmentados, ocelos presentes, isolados, papila hialina proximal, anfigastros bífidos, espaçados, abertura do sinus estreita, margem inteira, base reta, quilhas do perianto 5, inteiras. Reprodução vegetativa ausente.

Chave para as espécies

1. Ápice obtuso, ocelos presentes

11.1. M. bullata

1'. Ápice agudo, ocelos ausentes

11.2. M. epiphylla

11.1. Microlejeunea bullata (Taylor) Steph., Hedwigia 29: 90. 1890.

Fig. 52 G-K

Gametófitos verde-claros a amarelados, pequenos, delicados, ramos prostrados, ramificações tipo Lejeunea, hialoderme presente, merófito ventral 2 3(-4) células, lobos orbiculares, espaçados, ápice obtuso, margem inteira, células clorofiladas, ápice plano, células isodiamétricas, lisas, trigônios pequenos, oleocorpos segmentados, ocelos presentes, isolados, lóbulos quadráticos a orbiculares, inflados, tamanho em relação ao filídio 1/2-3/4, nunca reduzidos, ápice do lóbulo plano, dentes 1 , papila hialina proximal, anfigastros bífidos, espaçados, abertura do sinus estreita, margem inteira, largura em relação ao caulídio 1-3x, base reta, quilhas do perianto 5 , inteiras. Reprodução vegetativa ausente.

Material examinado: Minas Gerais, Santana do Riacho, Câmara 2006 p.p. (SP419689).

Associada a Lejeunea deplanata Nees. Ocorre nos estados do AC, AM, BA, CE, DF, ES, GO, MG, MS, MT, PA, PE, PR, RJ, RR, RS, SC, SE e SP. Na Serra do Cipó, cresce em folha.

11.2. Microlejeunea epiphylla Bischler in Bischler et al., Nova Hedwigia 5(1-2): 378. 1963.

Fig. $52 \mathrm{~L}-\mathrm{N}$

Gametófitos verde-claros a amarelados, ramos prostrados, tipo Lejeunea, merófito ventral 2-3(-4) células, lobos orbiculares, espaçados, ápice agudo, margem inteira, células clorofiladas, ápice plano, células isodiamétricas, lisas, trigônios pequenos, oleocorpos segmentados, ocelos ausentes, lóbulos quadráticos a orbiculares, inflados, tamanho em relação ao filídio 1/2-3/4, nunca reduzidos, ápice do lóbulo plano, dentes 1, papila hialina proximal, anfigastros bífidos, espaçados, abertura do sinus estreita, margem inteira, largura em relação ao caulídio 1-3x, base reta, quilhas do perianto 5 , inteiras. Reprodução vegetativa ausente.
Material examinado: Minas Gerais, Santana do Riacho, Serra da Bandeirinha, O. Yano \& Wanderley 10807 p.p. (SP220500)

Associada a Lejeunea deplanata Nees. Ocorre nos estados de AL, AP, BA, CE, ES, GO, MG, MS, PA, $\mathrm{PB}, \mathrm{PE}, \mathrm{RS}, \mathrm{SE}, \mathrm{SP}$ e TO. Na Serra do Cipó, cresce em tronco vivo.

\section{Schiffneriolejeunea Verd.}

Gametófitos verde-escuros a marrons, medianos, ramos prostrados, tipo Frullania, hialoderme presente, lobos orbiculares, sobrepostos, ápice obtuso, margem inteira, células clorofiladas, ápice plano, células mais longas que largas, lisas, trigônios grandes, oleocorpos segmentados, ocelos ausentes, papila hialina proximal, anfigastros inteiros, sobrepostos, margem inteira, base curva, quilhas do perianto 5, inteiras. Reprodução vegetativa ausente.

\subsection{Schiffneriolejeunea polycarpa (Nees)} Gradst., J. Hattori Bot. Lab. 38: 355. 1974.

Fig. 52 O-S

Gametófitos verde-escuros a marrons, medianos, ramos prostrados, tipo Frullania, hialoderme presente, merófito ventral 20-30(-40) células, lobos orbiculares, sobrepostos, ápice obtuso, margem inteira, células clorofiladas, ápice plano, células mais longas que largas, lisas, trigônios grandes, oleocorpos segmentados, ocelos ausentes, lóbulos claviformes, inflados, tamanho em relação ao filídio 1/3, nunca reduzidos, ápice do lóbulo plano, dentes 1 , papila hialina proximal, anfigastros inteiros, sobrepostos, margem inteira, largura em relação ao caulídio 4-5x, base curva, quilhas do perianto 5, inteiras. Reprodução vegetativa ausente.

Material examinado: Minas Gerais, Santana do Riacho, Serra da Bandeirinha, O. Yano \& Wanderley 10735 , $10740,10744,10750,10758,10761,10778,10789,10795$, $10800,10812,10822,10843,10853$ p.p., 10857, 10873, $10875,10879,10881,10883,10885,10891,10894,10886$, 10889 (SP220429; SP220434; SP220438; SP220444; 


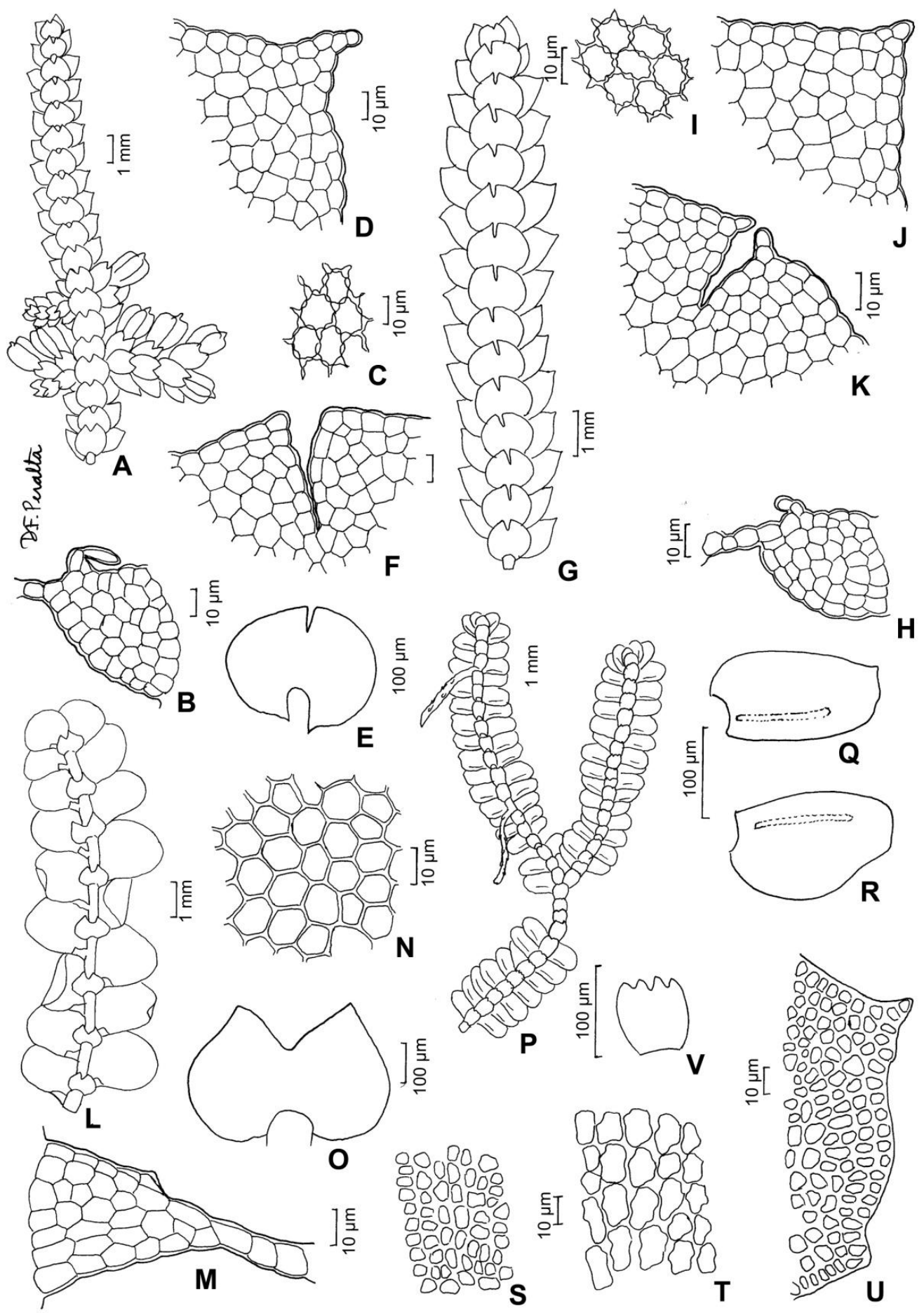

Fig. 53. Taxilejeunea isocalycina (Nees) Steph. A. aspecto do gametófito. B. células do lóbulo do filídio. C. células da lâmina do filídio. D. ápice do filídio. E. anfigastros. F. detalhe do ápice do anfigastro. Taxilejeunea pterigonia (Lehm. \& Lindenb.) Schiffn. G. aspecto do gametófito. H. células do lóbulo do filídio. I. células da lâmina do filídio. J. ápice do filídio. K. detalhe do ápice do anfigastro. Taxilejeunea terricola (Spruce) Steph. L. aspecto do gametófito. M. células do lóbulo do filídio. N. células da lâmina do filídio. O. anfigastro. Bazzania heterostipa (Steph.) Fulford. P. aspecto do gametófito. Q-R. filídios. S. células da lâmina do filídio. T. células da vita. U. ápice do filídio. V. anfigastro (A-F. O. Yano \& Wanderley 10867; G-K. Vital 1215; L-O. Giulietti et al. 9780; P-V. Vital 1216). 
Flora da Serra do Cipó, Minas Gerais: Briófitas (Anthocerotophyta, Bryophyta e Marchantiophyta)

SP220452; SP220455; SP220471; SP220482; SP220488; SP220493; SP220505; SP220515; SP220536; SP220546; SP220550; SP220566; SP220568; SP22057; SP220574; SP220576; SP220578; SP220584; SP220587; SP220579; SP220582).

Associada a Frullania brasiliensis Raddi. Ocorre nos estados de AC, AL, AM, BA, CE, DF, ES, GO, MG, MS, MT, PA, PB, PE, RJ, RR, RS, SC, SE e SP. Na Serra do Cipó, cresce em tronco vivo e caído. O perianto desta espécie é muito característica pois é imerso nas brácteas e pluriplicado sendo cada prega é inflada.

\section{Taxilejeunea (Spruce) Schiffn}

Gametófitos verde-claros a amarelados, medianos, ramificações tipo Lejeunea, hialoderme presente, merófito ventral 20-30(-40) células, lobos orbiculares, sobrepostos, ápice agudo, margem inteira, células clorofiladas, ápice plano, células isodiamétricas, lisas, trigônios pequenos, oleocorpos segmentados, ocelos ausentes, papila hialina proximal, anfigastros bífidos, sobrepostos, abertura do sinus estreita, margem inteira, base decurrente, quilhas do perianto ausentes. Reprodução vegetativa ausente.

1, Quilhas do perianto ausentes

13.1. T. isocalycina

1'. Quilhas do perianto 5 .

2. Ápice obtuso; quilhas inteiras

13.3. T. terricola

2'. Ápice agudo; quilhas laciniadas

13.2. T. pterigonia

13.1. Taxilejeunea isocalycina (Nees) Steph., Spec. Hepat. 5: 469. 1914.

Fig. $53 \mathrm{~A}-\mathrm{F}$

Gametófitos verde-claros a amarelados, medianos, ramos ascendentes ou pêndulos, ramificações tipo Lejeunea, hialoderme presente, merófito ventral 20-30(-40) células, lobos orbiculares, sobrepostos, ápice agudo, margem inteira, células clorofiladas, ápice plano, células isodiamétricas, lisas, trigônios pequenos, oleocorpos segmentados, ocelos ausentes, lóbulos claviformes, inflados, tamanho em relação ao filídio 1/4-1/6, às vezes reduzidos, ápice do lóbulo plano, dentes 1, papila hialina proximal, anfigastros bífidos, sobrepostos, abertura do sinus estreita, margem inteira, largura em relação ao caulídio 6-10x, base decurrente, quilhas do perianto ausentes. Reprodução vegetativa ausente.

Material examinado: Minas Gerais, Santana do Riacho, Serra da Bandeirinha, O. Yano \& Wanderley 10867 (SP220560).

Ocorre nos estados de ES, MG, RJ, RS e SP. $\mathrm{Na}$ Serra do Cipó, cresce em tronco vivo.

13.2. Taxilejeunea pterigonia (Lehm. \& Lindenb.) Schiffn. in Engler \& Prantl, Natürl. Pflanzenfam. 1(3): 125. 1893.

Fig. 53 G-K

Gametófitos verde-claros a amarelados, medianos, ramos ascendentes ou pêndulos, ramificações tipo Lejeunea, hialoderme presente, merófito ventral 20-30(-40) células, lobos orbiculares, sobrepostos, ápice agudo, margem inteira, células clorofiladas, ápice plano, células isodiamétricas, lisas, trigônios pequenos, oleocorpos segmentados, ocelos ausentes, lóbulos claviformes, inflados, tamanho em relação ao filídio $1 / 4-1 / 6$, às vezes reduzidos, ápice do lóbulo plano, dentes 1, papila hialina proximal, anfigastros bífidos, sobrepostos, abertura do sinus estreita, margem inteira, largura em relação ao caulídio 6-10x, base decurrente, quilhas do perianto 5, laciniadas, reprodução vegetativa ausente.

Material examinado: Minas Gerais, Conceição do Mato Dentro, Serra do Cipó, Vital 1215 (SP87118); Santana do Riacho, Pirani et al. 10377 p.p. (SP230733, SPF).

Associada a Syrrhopodon gaudichaudii Mont. Ocorre nos estados de AM, BA, ES, GO, MG, RJ, RS, SC e SP. Na Serra do Cipó, cresce em solo.

13.3. Taxilejeunea terricola (Spruce) Steph., Spec. Hepat. 5: 480. 1914.

Fig. $53 \mathrm{~L}-\mathrm{O}$

Gametófitos verde-claros a amarelados, pequenos, delicados, ramos ascendentes ou pêndulos, ramificações tipo Lejeunea, hialoderme presente, merófito ventral 20-30(-40) células, lobos orbiculares, sobrepostos, ápice obtuso, margem inteira, células clorofiladas, ápice plano, células isodiamétricas, lisas, trigônios pequenos, oleocorpos segmentados, ocelos ausentes, lóbulos claviformes, inflados, tamanho em relação ao filídio $1 / 4-1 / 6$, às vezes reduzidos, ápice do lóbulo plano, dentes 1 , papila hialina proximal, anfigastros bífidos, sobrepostos, abertura do sinus estreita, margem inteira, largura em relação ao caulídio 6-10x, base decurrente, quilhas do perianto 5 , inteiras. Reprodução vegetativa ausente.

Material examinado: Minas Gerais, Santana do Riacho, Giulietti et al. 9780 (SP222585, SPF42442). 
Ocorre nos estados da BA, GO, RJ e SP. Na Serra do Cipó, cresce em solo.

\section{Lepidoziaceae}

Gametófitos folhosos, avermelhados ou marrons ou verde-claros, estolões ausentes, hábito ascendente ou prostrado, ramificações do tipo ventral intercalar. Filídios íncubos ou súcubos, inserção transversal, divididos em segmentos ou inteiros, margem inteira, margem na região ventral reta, margem na região dorsal plana, sem células diferenciadas ou com células diferenciadas formando vita, células retangulares, quadráticas ou irregulares, parede celular uniformemente delgada ou uniformemente espessada, cutícula lisa ou papilosa, trigônios presentes ou ausentes, células da margem iguais as interiores, ocelos ausentes, anfigastro inteiro, pequenos (ca. 1 a 2 x larg. do caulídio), denteado ou inteiro, rizóides monomórficos, ao longo de toda a porção ventral, incolores. Gametângios laterais em pequenas ramificações, anterídios em eixos especializados com filídios modificados, perianto quilhado, cápsula alongada. Reprodução vegetativa por filídios caducos.

É uma família amplamente distribuída no Brasil, caracterizada principalmente pelo hábito muito ramificados dos gametófitos e ausência de lóbulo. Ocorre principalmente nos mais variados substratos. Para a identificação das espécies é necessário análise da morfologia do anfigastro e das células da lâmina do filídio. No Brasil ocorrem 13 gêneros e 69 espécies; na Serra do Cipó ocorrem sete gêneros e 11 espécies.

Bibliografia básica: Engel \& Smith Merrill (2004); Gradstein \& Costa (2003); Gradstein et al. (2001); Yano \& Peralta (2008).

1. Filídios divididos em segmentos filiformes

1'. Filídios não divididos em segmentos filiformes.

2. Filídios inseridos obliquamente, sem anfigastro

2'. Filídios inseridos perpendicularmente, com anfigastro.

3. Ramos flageliformes surgindo na porção ventral do gametófito

3'. Ramos flageliformes ausentes.

4. Filídios quilhados, a quilha formando uma asa

4'. Filídios sem quilhas.

5. Filídios bífidos

5. Filídios quadrífidos.

6 . Filídios com cutícula verrucosa

6'. Filídios com cutícula lisa

6. Telaranea

7. Zoopsidella

1. Bazzania

4. Micropterygium

5. Paracromastigum

2. Kurzia

3. Lepidozia

\section{Bazzania A. Gray}

Gametófitos folhosos, verde-claros, hábito ascendente, ramificações do tipo ventral intercalar. Filídios íncubos, inteiros, margem denteada, margem na região ventral reta, margem na região dorsal plana, sem células diferenciadas ou com células diferenciadas formando vita, células retangulares, quadráticas ou irregulares, parede celular uniformemente espessada, cutícula lisa, trigônios presentes ou ausentes, células da margem iguais as interiores, ocelos ausentes, anfigastro denteado.

\section{Chave para as espécies}

1. Região mediana do filídio apresentando fileira de células diferenciadas, ápice dos filídios com um dente ou inteira

1'. Região mediana do filídio sem fileira de células diferenciadas, ápice com 3 dentes 
Flora da Serra do Cipó, Minas Gerais: Briófitas (Anthocerotophyta, Bryophyta e Marchantiophyta)

1.1. Bazzania heterostipa (Steph.) Fulford, Bull. Torrey Bot. Club 86: 410. 1959.

Fig. $53 \mathrm{P}-\mathrm{V}$

Gametófitos pequenos. Filídios inseridos perpendicularmente, ápice obtuso, inteiro ou com um dente, células irregulares, trigônios apenas na porção mediana, formando fileira de células diferenciada, anfigastro pequenos com 4-5 dentes.

Material examinado: Minas Gerais, Conceição do Mato Dentro, Vital 1216 (SP87119).

Ocorre nos estados de AL, BA, ES, MG, PE, PR, RJ, RS, SC e SP. Na Serra do Cipó, cresce em tronco vivo. Esta espécie é facilmente identificada pela fileira de células diferenciadas no centro do filídio formando a vita, apresenta ainda um coloração marrom esverdeado.

1.2. Bazzania hookeri (Lindenb.) Trevis., Mem. R. Inst. Lombardo Cl. Sci. ser. 3, 13: 414. 1877.

Fig. 54 A-E

Gametófitos medianos. Filídios inseridos perpendicularmente, ápice trífido, células regulares, hexagonais, trigônios grandes, sem fileiras de células diferenciadas na porção mediana, anfigastros pequenos, 3-4 dentes.

Material examinado: Minas Gerais, Pirapama, Starling s.n. (SP368140).

Ocorre nos estados de AM, BA, ES, MG, PE, PR, RJ, RR, RS, SC e SP. Na Serra do Cipó, cresce em rocha. Esta é uma espécie bastante comum e amplamente distribuída, possui o hábito robusto e uma coloração verde escuro característica.

\section{Kurzia G. Martins}

Gametófitos folhosos, verde-claros, hábito prostrado, ramificações do tipo ventral intercalar. Filídios transversos, inteiros, margem denteada, margem na região ventral reta, margem na região dorsal plana, sem células diferenciadas, células retangulares, quadráticas ou irregulares, parede celular uniformemente espessada, cutícula lisa ou rugosa, trigônios presentes ou ausentes, células da margem iguais as interiores, ocelos ausentes, anfigastro inteiro, denteado.

2.1. Kurzia capillaris (Sw.) Grolle, Revue Bryol. Lichénol. 32: 178. 1963.

Fig. 54 F-K

Gametófitos muito pequeno. Filídios inseridos perpendicularmente, raramente súcubos, profundamente divididos em quatro segmentos, margem inteira; células irregulares; parede celular delgada, sem trigônios. Anfigastros atingindo a metade do compr. dos filídios.

Material examinado: Minas Gerais, Conceição do Mato Dentro, Vital 1229, 1241 p.p. (SP87117; SP87129); O. Yano 505 p.p. (SP132046); Santana do Riacho, Pirani et al. 10332 (SP230720); O. Yano \& Wanderley 10649 p.p., 10688 (SP220344; SP220383); Serra da Bandeirinha, O. Yano \& Wanderley 10863 p.p. (SP220556); Câmara 1902 p.p. (SP419644), Câmara et al. 2093 (SP419708); Dias Neto 144 (SP419774); Dias Neto 193 (SP419804).

Associada a Fissidens pellucidus Hornsch., Marchantia chenopoda L., Cheilolejeunea acutangula (Nees) Grolle, Jungermannia amoena Lindenb. \& Gottsche, Riccardia chamedryfolia (With.) Grolle, Telaranea nematodes (Gottsche ex Austin) M. Howe e Zoopsidela macella (Spruce) Steph. Ocorre nos estados de AM, BA, CE, DF, GO, MG, MT, RJ e SP. $\mathrm{Na}$ Serra do Cipó, cresce em rocha, solo e tronco vivo. Esta espécie é comumente encontrada em áreas de solo arenoso associadas a cursos de água ou locais encharcados.

\section{Lepidozia (Dumort.) Dumort.}

Gametófitos folhosos, verde-claros a verdeescuros, hábito ascendente, ramificações do tipo ventral intercalar. Filídios íncubos, denteados, margem inteira, na região ventral reta, margem na região dorsal plana, sem células diferenciadas ou com células diferenciadas formando vita, células retangulares, quadráticas ou irregulares, parede celular uniformemente delgada, cutícula lisa, trigônios ausentes, células da margem iguais as interiores, ocelos ausentes, anfigastro denteado. 

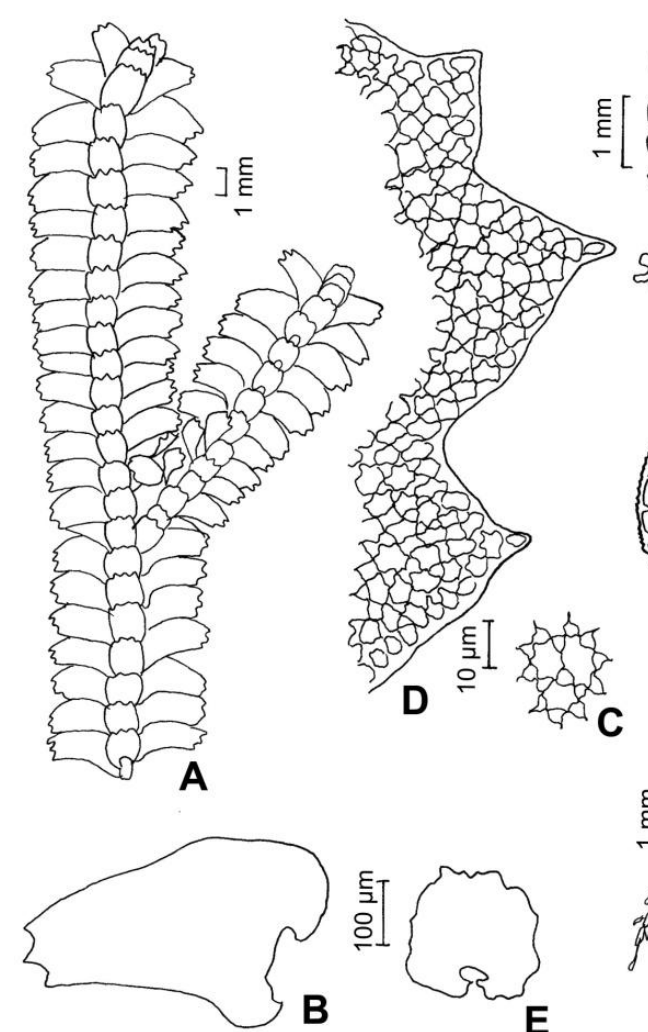

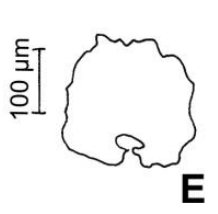

$$
\text { 新 }
$$

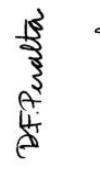

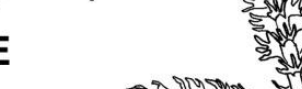

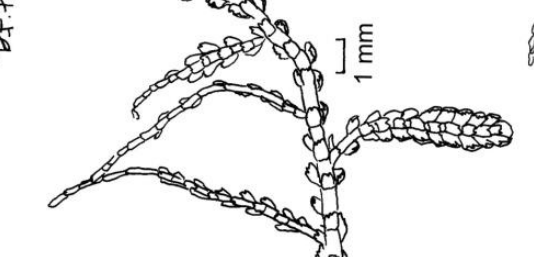

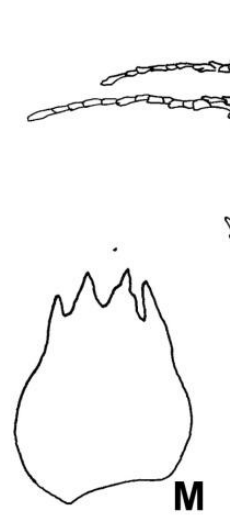

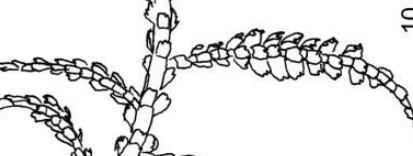

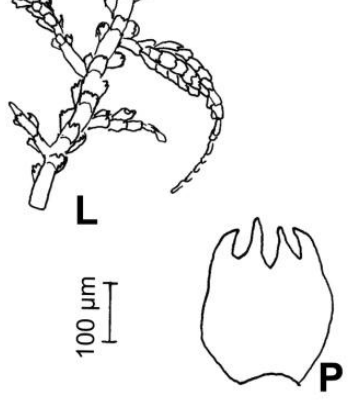

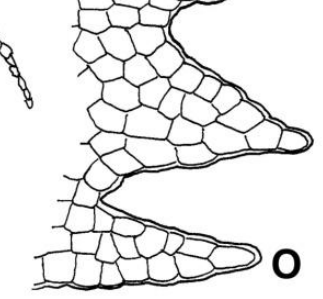

(2)

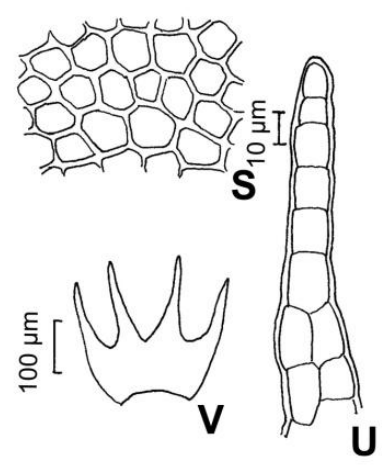

Fig. 54. Bazzania hookeri (Lindenb.) Trevis. A. aspecto do gametófito. B. filídio. C. células da lâmina do filídio. D. ápice do filídio. E. anfigastro. Kurzia capillaris (Sw.) Grolle. F. aspecto do gametófitos. G. detalhe do ramo. H. filídio. I-K. anfigastros. Lepidozia cupressina (Sw.) Lindenb. L. aspecto do gametófito. M. filídio. N. células da lâmina do filídio. O. ápice do filídio. P. anfigastro. Lepidozia inaequalis (Lehm. \& Lindenb.) Lehm. \& Lindenb. Q. aspecto do gametófito. R. filídio. S. células da lâmina do filídio. T-U. detalhe dos dentes do filídio. V. anfigastro (A-E. Starling s.n.; F-K. Vital 1229; L-P. Vital 1224; Q-V. Dias Neto 153 p.p.). 
Flora da Serra do Cipó, Minas Gerais: Briófitas (Anthocerotophyta, Bryophyta e Marchantiophyta)

3.1. Lepidozia cupressina (Sw.) Lindenb. in Gottsche et al., Syn. Hepat.: 207. 1845.

Fig. 54 L-P

Gametófitos pequenos. Filídios inseridos perpendicularmente, oblongos, ápice com 4 dentes, ápice dos segmentos com 1-2 células, margem inteira, células irregulares, sem trigônios, anfigastros pouco menor que os filídios, 4 dentes, ápice dos segmentos com 1-2 células.

Material examinado: Minas Gerais, Conceição do Mato Dentro, Vital 1224 (SP87124).

Ocorre nos estados de BA, MG, PE, RJ e SP. Na Serra do Cipó, cresce em rocha.

3.2. Lepidozia inaequalis (Lehm. \& Lindenb.) Lehm. \& Lindenb. in Gottsche et al., Syn. Hepat.: 209. 1845.

Fig. $54 \mathrm{Q}-\mathrm{V}$

Gametófitos pequenos. Filídios inseridos perpendicularmente, oblongos, ápice com 4 dentes, ápice dos segmentos com 4-8 células, margem inteira, células irregulares, sem trigônios, anfigastros pouco menor que os filídios, 4 dentes, ápice dos segmentos com 4-8 células.

Material examinado: Minas Gerais, Santana do Riacho, Dias Neto 153 p.p. (SP419777).

Associada a Adelanthus carabayensis (Mont.) Grolle. Ocorre nos estados da BA, MG, PR, RJ, SC e SP. Na Serra do Cipó, cresce em rocha. Esta espécie é muito característica pelos longos ápices dos dentes dos filídios e anfigastros, sendo facilmente diferenciada das demais espécies do gênero.

\section{Micropterygium Lindenb., Nees \& Gottsche}

Gametófitos folhosos, verde-claros, hábito ascendente, ramificações do tipo ventral intercalar. Filídios súcubos, inteiros, margem inteira a crenulada, quilha na porção mediana formando asa, margem na região ventral reta, margem na região dorsal plana, sem células diferenciadas, células retangulares, quadráticas ou irregulares, parede celular uniformemente espessada, cutícula lisa, trigônios ausentes, células da margem iguais as interiores, ocelos ausentes, anfigastro denteado.

4.1. Micropterygium campanense Spruce ex Reimers, Hedwigia 73: 157. 1933.

Fig. 55 A-G

Gametófitos pequenos. Filídios oblongoligulados, ápice agudo, quilha na porção mediana grande formando asa, margem inteira, crenulada, células irregulares pluripapilosas, sem trigônios, anfigastros pequenos, inteiros até 3 dentes.
Material examinado: Minas Gerais, Santana do Riacho, Cachoeira Farofa, O. Yano \& Wanderley 10656 p.p., 10660 (SP220351; SP220355); Câmara et al. 2052 (SP419697).

Associada a Riccardia cataractarum (Spruce) Schiffn. Ocorre nos estados de BA, GO e MG. Na Serra do Cipó, cresce em rocha e solo. Esta é uma espécie bem caracterizada pela presença de uma trama de caulídios com inúmeros ramos ascendentes que ficam encurvados quando os gametófitos estão secos.

\section{Paracromastigum Fulford \& Taylor}

Gametófitos folhosos, verde-claros a avermelhados, hábito prostrado, ramificações do tipo ventral intercalar. Filídios súcubos, bífidos, margem inteira, na região ventral reta, margem na região dorsal plana, sem células diferenciadas, células retangulares, quadráticas ou irregulares, parede celular uniformemente delgada, cutícula lisa, trigônios ausentes, células da margem iguais as interiores, ocelos ausentes, anfigastro bífidos.

5.1. Paracromastigum pachyrrhizon (Nees) Fulford, Mem. New York Bot. Gard. 11(3): 390. 1968.

Fig. $55 \mathrm{H}-\mathrm{K}$

Gametófitos pequenos. Filídios oblongos, ápice bífido, margem inteira, células irregulares, quadráticas, sem trigônios, anfigastros pequenos, 1/3 ou menos compr. do filídio, bífido.

Material examinado: Minas Gerais, Santana do Riacho, O. Yano \& Wanderley 10697 p.p., 10710 p.p., 10870 p.p. (SP220392; SP220405; SP220563).

Associada a Gemmabryum acuminatum (Harv.), J.R. Spence \& H.P. Ramsay Dicranella hilariana (Mont.) Mitt., Riccardia cataractarum (Spruce) Schiffn. e Sphagnum sparsum Hampe. Ocorre nos estados de ES, GO, MG, RJ, SC e SP. Na Serra do Cipó, cresce em solo e rocha. Esta é uma espécie bastante comum em barrancos e beiras de estrada, no início do crescimento aparecem com o hábito prostrado e os filídios quase longitudinalmente inseridos no caulídio e quando colonizam o substrato apresentam vários ramos ascendentes com os filídios imbricados.

\section{Telaranea Spruce ex Schiffn.}

Gametófitos folhosos, verde-claros, hábito ascendente, ramificações do tipo ventral intercalar. Filídios transversais, divididos em segmentos, células retangulares, parede celular uniformemente delgada, cutícula lisa, trigônios ausentes, anfigastro divididos em segmentos. 


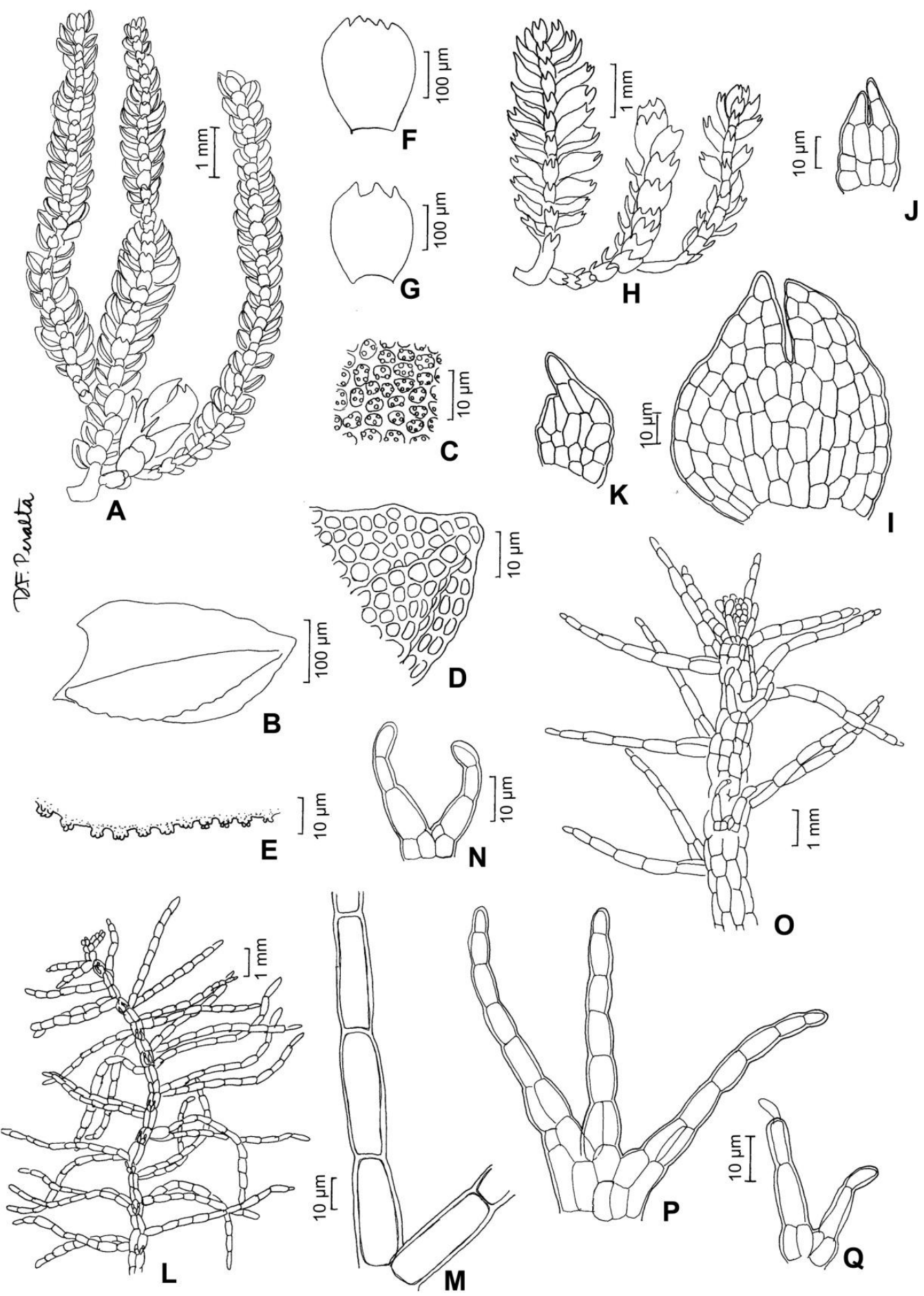

Fig. 55. Micropterygium campanense Spruce ex Reimers. A. aspecto do gametófito. B. filídio. C. células da lâmina do filídio. D. ápice do filídio. E. células da lâmina em vista lateral. F-G. anfigastros. Paracromastigum pachyrrhizon (Nees) Fulford. H. aspecto do gametófito. I. filí́dio. J-K. anfigastros. Telaranea diacantha (Mont.) J.J. Engel \& G.L. Merrill. L. aspecto do gametófito. M. detalhe da base do filídio. N. anfigastro. Telaranea nematodes (Gottsche ex Austin) M. Howe. O. aspecto do gametófito. P. filídio. Q. anfigastro (A-G. O. Yano \& Wanderley 10656 p.p.; H-K. O. Yano \& Wanderley 10697 p.p.; L-N. Pirani et al. 5548 p.p.; O-Q. Vital 1218) 
Flora da Serra do Cipó, Minas Gerais: Briófitas (Anthocerotophyta, Bryophyta e Marchantiophyta)

Chave para as espécies

1. Base dos segmentos dos filídios com uma célula, raramente duas, anfigastros com 1 célula compr.

6.1. T. diacantha

1'. Base dos segmentos com 2 ou mais células, anfigastros com 2-3 células compr.

6.2. T. nematodes

6.1. Telaranea diacantha (Mont.) J.J. Engel \& G.L. Merrill, Fieldiana Bot. n. ser., 44: 145. 2004.

Fig. $55 \mathrm{~L}-\mathrm{N}$

Gametófitos diminutos, hialinos, caulídio irregularmente ramificados, secção transversal 6 células corticais, 6 medulares. Filídios em 3 longos filamentos uniseriados, 4-5 células compr., células retangulares paredes lisas, anfigastros pequenos, divididos em 2 segmentos uniseriados, 1 célula comprimento.

Material examinado: Minas Gerais, Santana do Riacho, Pirani et al. 5548 p.p. (SP388846, SPF).

Associada a Calypogeia laxa Lindenb. \& Gottsche e Symphyogyna podophylla (Thumb.) Mont. \& Nees. Ocorre nos estados de AL, AM, BA, DF, ES, PE, RJ, SC e SP. Na Serra do Cipó, cresce em solo. Esta espécie é facilmente diferenciada pelos longos filamentos uniseriados, inclusive na base onde estão inseridos no caulídio. Esta característica a diferencia da espécie mais comum $T$. nematodes que apresenta na base dos filamentos do filídio 2 até várias células.

6.2. Telaranea nematodes (Gottsche ex Austin) M. Howe, Bull. Torrey Bot. Club 29: 284. 1902.

Fig. $55 \mathrm{O}-\mathrm{Q}$

Gametófitos diminutos, hialinos. Caulídio irregularmente ramificado, secção transversal, 8 células corticais, 9 células medulares menores. Filídios 2 longos filamentos unisseriados, 4-7 células compr. Células retangulares, paredes retas. Anfigastros pequenos, divididos em 2 segmentos uniseriados, 2-3 células compr., 2-3 células na base.

Material examinado: Minas Gerais, Conceição do Mato Dentro, Vital 1218, 1233 (SP87121; SP87127); O. Yano 505 p.p. (SP132046); Santana do Riacho, Pirani et al. 10332 p.p. (SP230720, SPF); O. Yano \& Wanderley 10665 p.p., 10866 p.p. (SP220360; SP220559); Dias Neto140 (SP419771).

Associada a Cephalozia crassifolia (Gottsche ex Austin) M. Howe, Isopterygium tenerifolium Mitt., Callicostella pallida (Hornsch.) Ångstr., Kurzia capillaris (Sw.) Grolle e Neesioscyphus homophyllus (Nees) Nees. Ocorre nos estados de AC, AM, BA, CE, DF, ES, GO, MG, MS, MT, RJ, RR, RS, SC, SE e SP. $\mathrm{Na}$ Serra do Cipó, cresce em cáudice de samambaia, rocha e solo. Esta é uma espécie comum e amplamente distribuída, comumente encontrada em serrapilheira. Pode ser confundida com $T$. diacantha, veja comentários nesta espécie.

\section{Zoopsidella R.M. Schust.}

Gametófitos folhosos, verde-claros a hialinos. Filídios inseridos transversalmente, bífidos, margem inteira, sem células diferenciadas, células quadráticoirregulares, parede celular uniformemente delgada, cutícula lisa, trigônios ausentes, células da margem iguais as interiores, anfigastro ausente.

Chave para as espécies

1. Ápice do filídio obtuso

7.1. Z. integrifolia

1'. Ápice do filídio obliquamente agudo 7.2. Z. macella

7.1. Zoopsidella integrifolia (Spruce) R.M. Schust., Bull. Nat. Sci. Mus. Tokyo, s. n., 12(3): 666. 1969.

Fig. 56 A-C

Gametófitos pequenos. Filídios oblongos, bífidos, ápice dos segmentos obtuso, 2 papilas mucilaginosas, margem inteira, obliquamente inseridos, células irregulares, sem trigônios, anfigastros ausentes.

Santana do Riacho, Cachoeira Farofa, O. Yano \& Wanderley 10640 p.p. (SP220335).
Associada a Syrrhopodon tortilis Hampe. Ocorre nos estados de AM, BA, DF, GO, MG, MT, PA, SE e SP. Na Serra do Cipó, cresce em rocha.

7.2. Zoopsidella macella (Spruce) R.M. Schust., Bull. Nat. Sci. Mus. Tokyo 12(3): 666. 1969.

Fig. 56 D-G

Gametófitos pequenos. Filídios oblongos, bífidos, ápice dos segmentos agudo, 2 papilas mucilaginosas obliquamente inseridas, células irregulares, sem trigônios, anfigastro ausente. 

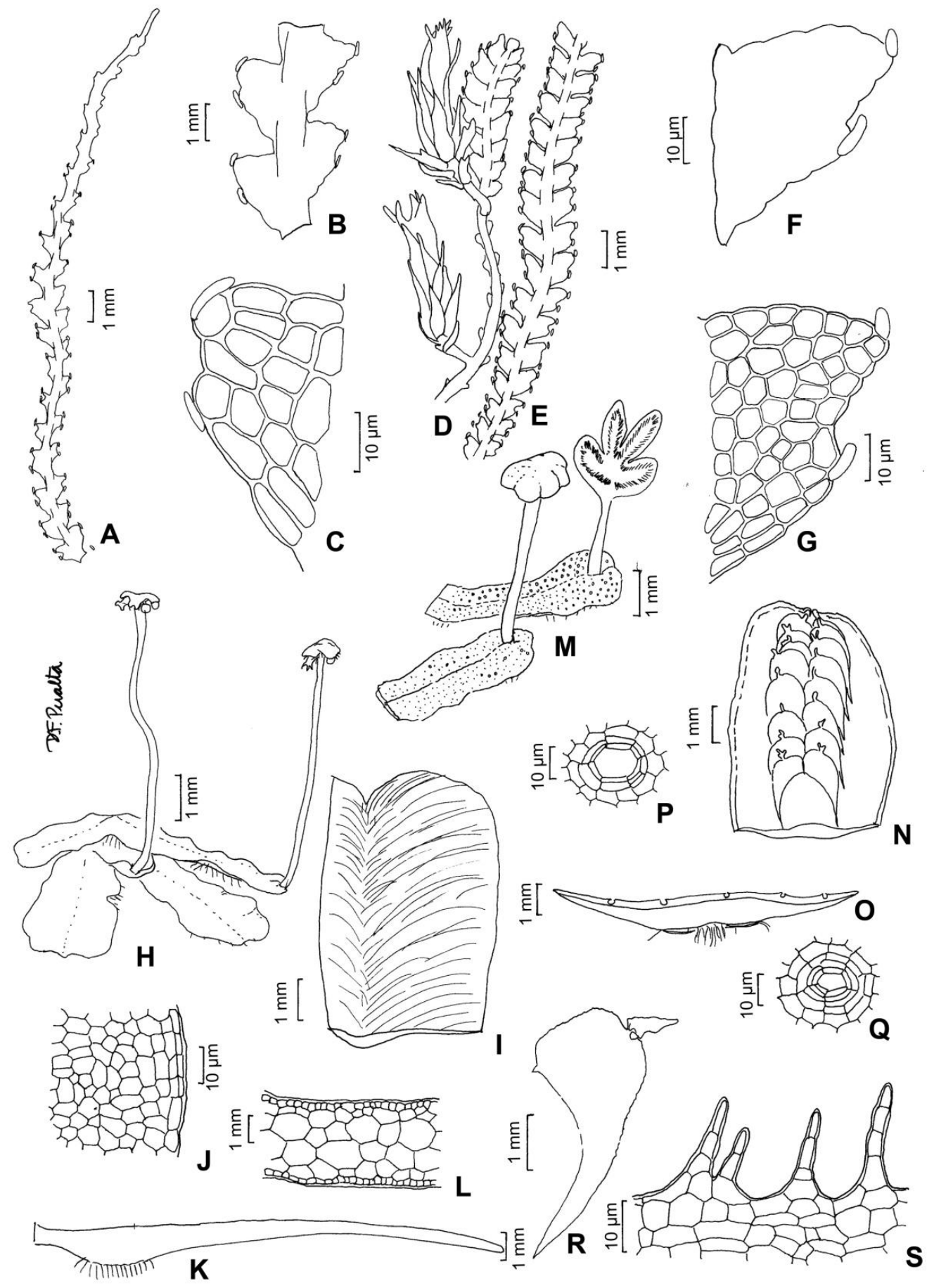

Fig. 56. Zoopsidella integrifolia (Spruce) R.M. Schust. A. aspecto do gametófito. B. detalhe do gametófito. C. filídio. Zoopsidela macella (Spruce) R.M. Schust. D-E. aspecto do gametófito. F-G. filídios. Dumortiera hirsuta (Sw.) Nees. H. aspecto do gametófito. I. lado ventral do talo. J. células da margem do talo. K. esquema da secção transversal do talo. L. secção transversal do talo. Marchantia chenopoda L. M. aspecto do gametófito. N. lado ventral do talo. O. esquema da secção transversal do talo. P-Q. poros. R. escama. S. cílios do conceptáculo (A-C. O. Yano \& Wanderley 10640 p.p.; D-G. O. Yano \& Wanderley 10649 p.p.; H-L. Vital 7588 p.p.; M-S. Vital 1260). 
Flora da Serra do Cipó, Minas Gerais: Briófitas (Anthocerotophyta, Bryophyta e Marchantiophyta)

Material examinado: Minas Gerais, Santana do Riacho, O. Yano \& Wanderley 10649 p.p. (SP220344).

Associada a Kurzia capillaris (Sw.) Grolle. Ocorre nos estados AM, GO, MT, PA e SE. Na Serra do Cipó, cresce em rocha.

\section{Marchantiaceae}

Gametófitos talosos, verde-escuros, estolões ausentes, hábito prostrado, ramificações dicotômicas ou irregular, sem diferenciação de nervura central, camadas de células diferenciadas, células quadráticoirregulares, parede celular uniformemente delgada, cutícula lisa, trigônios ausentes, células da margem iguais as interiores, ocelos ausentes, anfigastro ausente, rizóides dimórficos (lisos e pontuados) ou escamas, ao longo de toda a porção ventral, incolores. Gametângios em anteridióforos e arquegonióforos, anterídios superfície do talo, arquegônios em pseudoperianto, liso, cápsula esférica, reprodução vegetativa conceptáculos, hábitat de ocorrência mesofitico ou em locais úmidos, substrato solo.

É uma família amplamente distribuída principalmente na área de Floresta Atlântica do Brasil, caracterizada principalmente pelos talos prostrado e pelas estruturas reprodutivas elevadas em pedúnculos. Ocorre principalmente terrestre e rupícola. Para a identificação das espécies é necessário análise da secção transversal do talo e das escamas encontradas na porção ventral. No Brasil ocorrem dois gêneros e nove espécies; na Serra do Cipó ocorrem os dois gêneros e duas espécies.

Bibliografia básica: Bischler-Causse et al. (2005); Gradstein \& Costa (2003); Gradstein et al. (2001); Hässel de Menéndez (1962); Vianna (1985); Yano \& Peralta (2008).

Chave para os gêneros

1. Talo em secção transversal com diferenciação de tecidos, poros na superfície dorsal, escamas púrpuras na superfície ventral ...

2. Marchantia

1'. Talo em secção transversal sem diferenciação, sem poros, sem escamas

1. Dumortiera

\section{Dumortiera Nees}

Gametófitos

talosos,

verde-escuros, ramificações dicotômicas ou irregular, camadas de células não diferenciadas, sem poros na superfície dorsal, células quadrático-irregulares, anfigastro ausente, rizóides lisos, escamas ausentes, ao longo de toda a porção ventral, incolores. Gametângios em anteridióforos e arquegonióforos, anterídios superfície do talo, arquegônios em pseudoperianto, liso, cápsula esférica, reprodução vegetativa conceptáculos.

1.1. Dumortiera hirsuta (Sw.) Nees in Martius, Flora Brasil. enum. Plant. 1(1): 307. 1833.

Fig. $56 \mathrm{H}-\mathrm{P}$

Gametófitos talosos, verde-escuros, secção transversal do talo apresentando células epidérmicas menores que as medulares, células da lâmina irregulares, isodiamétricas, as da margem mais longas que largas, superfície ventral densamente radiculosa, superfície dorsal sem poros.

Material examinado: Minas Gerais, Conceição do Mato Dentro, Vital 7588 p.p. (SP132815).

Associada a Epipterygium puiggarii (Geh. \& Hampe) Broth. Ocorre nos estados de AC, AM, DF, ES, MG, MS, MT, PA, PR, RJ, RS, SC e SP. Na Serra do Cipó, cresce em solo. Esta é a única espécie da família que não possui escamas na porção ventral e poros na porção dorsal.

\section{Marchantia L.}

Gametófitos talosos,

verde-escuros, ramificações dicotômicas ou irregular, camadas de células diferenciadas, poros na superfície dorsal, células quadrático-irregulares, anfigastro ausente, rizóides dimórficos (lisos e pontuados) e escamas púrpuras, ao longo de toda a porção ventral, incolores. Gametângios em anteridióforos e arquegonióforos, anterídios superfície do talo, arquegônios em pseudoperianto, liso, cápsula esférica, reprodução vegetativa conceptáculos.

2.1. Marchantia chenopoda L., Spec. Plant. 2: 1137. 1753.

Fig. $56 \mathrm{M}-\mathrm{S}$

Gametófitos talosos, verde-escuros, secção transversal do talo apresentando diferenciação de tecidos com células da medula ventralmente e lamelas fotossintetizantes logo abaixo da epiderme, superfície ventral densamente radiculosa e com escamas púrpuras, superfície dorsal com poros.

Material examinado: Minas Gerais, Conceição do Mato Dentro, Vital 1260, 1261, 7587 p.p. (SP87135; SP87136; SP132814); Santana do Riacho, O. Yano \& Wanderley 10862, 10863 p.p. (SP220555; SP220556).

Associada a Cheilolejeunea acutangula (Nees) Grolle, Kurzia capillaris (Sw.) Grolle, Jungermannia amoena Lindenb. \& Gottsche, Noteroclada confluens 
Taylor ex Hook. \& Wilson e Vesicularia vesicularis (Schwägr.) Broth. Ocorre nos estados de AC, AM, DF, ES, MG, MT, PR, RJ, RS, SC e SP. Na Serra do Cipó, cresce em solo e rocha. Esta espécie é facilmente diferenciada pelo hábito robusto, talo espesso e com inúmeras escamas vináceas na porção ventral.

\section{Metzgeriaceae}

É uma família amplamente distribuída no Brasil, caracterizada principalmente pelo hábito delicado, cílios na margem do talo e com uma porção mediana fortemente diferenciada. Ocorre principalmente como corticícola. Para a identificação das espécies é necessário análise da morfologia das células marginais e da secção transversal do talo. No Brasil ocorrem um gênero e 29 espécies; na Serra do Cipó ocorrem duas espécies.
Bibliografia básica: Costa (1999, 2008); Gradstein \& Costa (2003); Gradstein et al. (2001); Yano \& Peralta (2008).

\section{Metzgeria Raddi}

Gametófitos talosos, verde-claros, hábito pendente ou prostrado, ramificações dicotômicas, talo dicotômica, nervura central bem diferenciada e nítida, secção transversal não diferenciadas, células hexagonais ou quadrático-irregulares, parede celular uniformemente delgada, cutícula lisa, trigônios ausentes, células da margem iguais as interiores, ocelos ausentes, anfigastro ausente, pelos mucilaginosos presentes ao longo de toda a porção ventral, incolores, gametângios ventrais no caulídio, abaixo dos filídios, anterídios em eixos especializados com filídios modificados, arquegônios, liso, cápsula esférica. Reprodução vegetativa por gemas na margem dos filídios. 1822

1.1. Metzgeria ciliata Raddi, Critt. Brasil.: 17.

Fig. $57 \mathrm{E}-\mathrm{G}$

Gametófitos talosos, verde-esbranquiçados, porção mediana formando uma nervura, secção transversal do talo apresentando 4 células epidérmicas na região dorsal e 2 na ventral, 12-15 medulares, células da lâmina regulares, hexagonais, marginais não diferenciadas, 2 pêlos mucilaginosos a cada célula na margem.

Material examinado: Minas Gerais, Santana do Riacho, Câmara 1986 p.p. (SP419682).

Associada a Lejeunea flava (Sw.) Nees. Ocorre nos estados da BA, ES, GO, MG, PB, PE, PR, RJ, RS, SC e SP. Na Serra do Cipó, cresce em folha.

1.2. Metzgeria conjugata Lindb., Acta Soc. Sci. Fenn. 10: 495. 1875.

Fig. 57 A-D

Gametófitos talosos, verde-esbranquiçados, porção mediana formando uma nervura, secção transversal do talo apresentando 4 células epidérmicas na região dorsal e ventral, 30 medulares, células da lâmina regulares, hexagonais, marginais não diferenciadas, 1 pêlo mucilaginoso a cada 2 células na margem.

Material examinado: Minas Gerais, Santana do Riacho, Serra da Bandeirinha, Prado s.n. p.p. (SP220630).
Associada a Marchesinia brachiata (Sw.) Schiffn. Ocorre nos estados de AL, CE, ES, GO, MG, PE, PR, RJ, RS e SP. Na Serra do Cipó, cresce em tronco vivo.

\section{Pallaviciniaceae}

Gametófitos talosos, verde-claros, estolões ausentes, hábito ascendente ou prostrado, ramificações dicotômicas. Talo dicotômico, nervura central bem diferenciada e nítida, seção transversal com porção central de células pequenas e espessadas. Células retangulares ou quadrático irregulares, parede celular uniformemente delgada, cutícula lisa, trigônios ausentes, células da margem iguais as interiores. Ocelos ausentes. Anfigastro ausente. Rizóides monomórficos, restritos à base dos ramos, incolores. Gametângios dorsais no caulídio, anterídios superfície do talo, arquegônios escamas ou pseudoperianto, liso. Cápsula alongada.

É uma família amplamente distribuída no Brasil, caracterizada principalmente pelo hábito robusto e por uma porção mediana fortemente diferenciada. Ocorre principalmente como terrestre e rupícola. Para a identificação das espécies é necessário análise da morfologia das células da secção transversal e margem do talo e das estruturas reprodutivas. No Brasil ocorrem quatro gêneros e 14 espécies; na Serra do Cipó ocorrem dois gêneros e quatro espécies.

Bibliografia básica: Gradstein \& Costa (2003); Gradstein et al. (2001); Hell (1969); Yano \& Peralta (2008). 

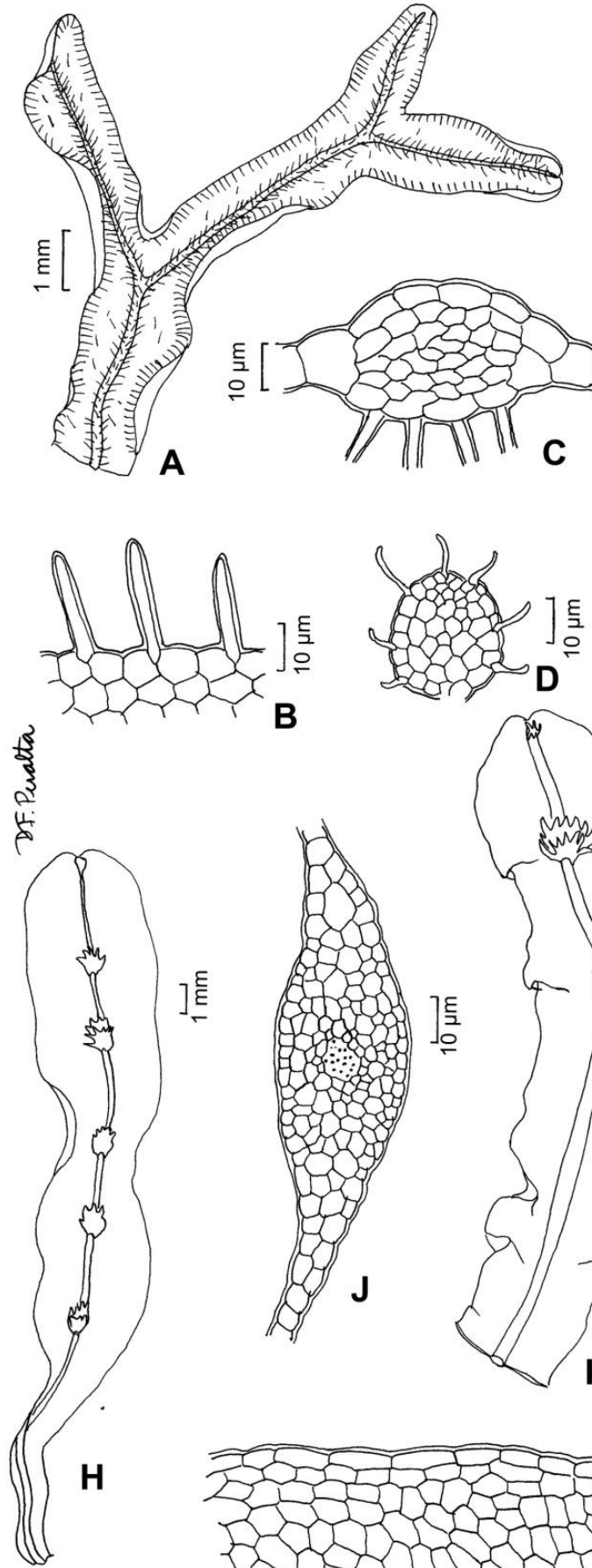

B
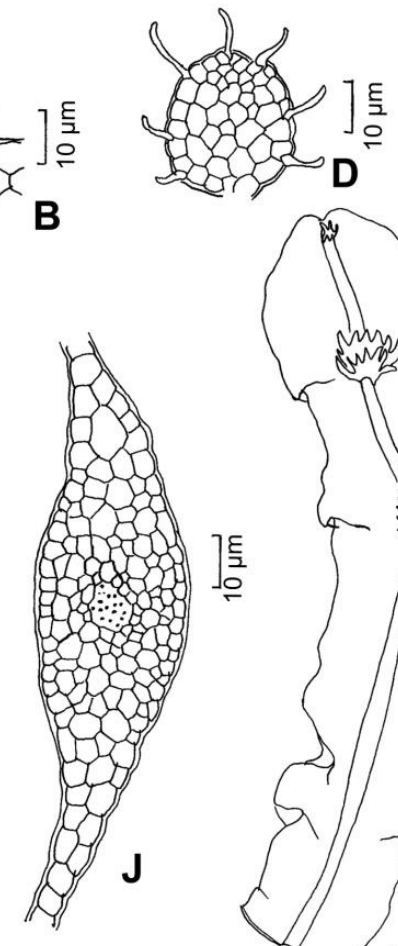

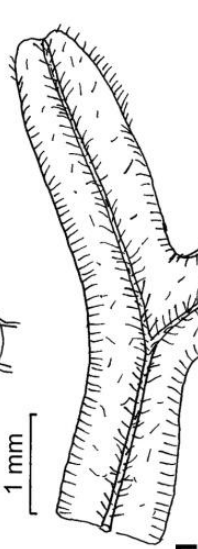

E
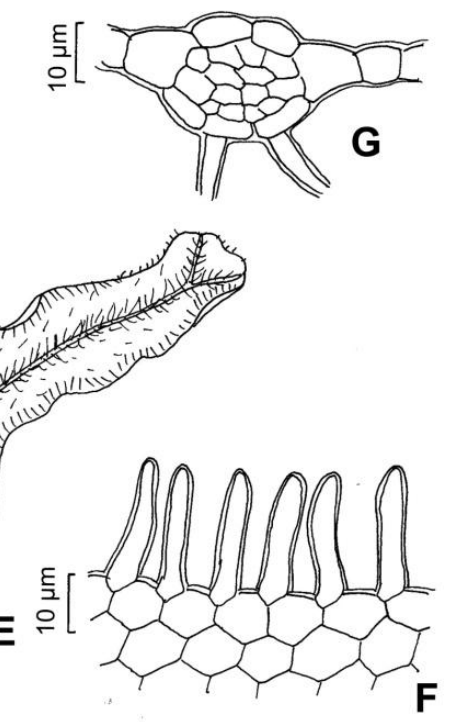

$\mathbf{F}$
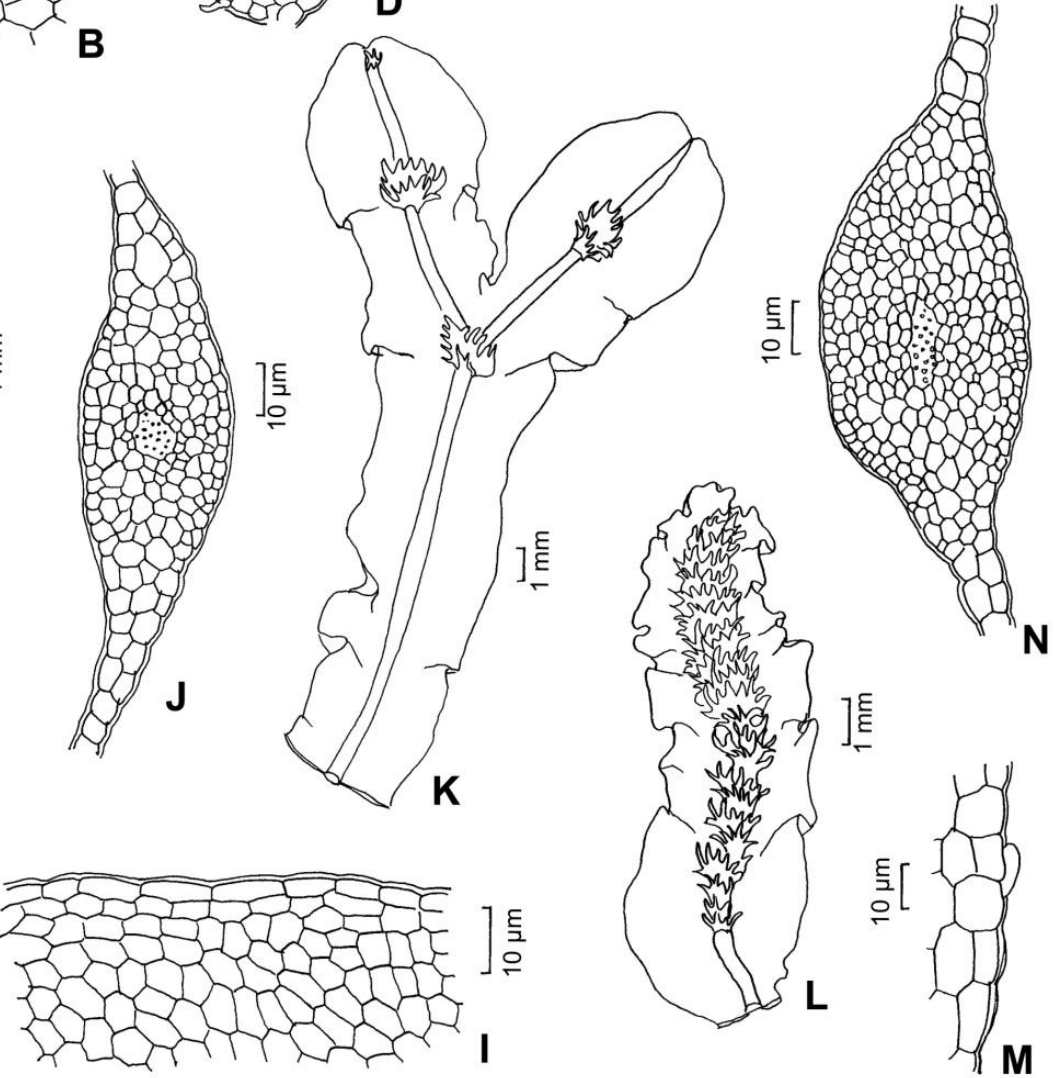

Fig. 57. Metzgeria ciliata Raddi. A. aspecto do gametófito. B. células da margem do talo. C. secção transversal do talo. D. gema. Metzgeria conjugata Lindb. E. aspecto do gametófito. F. células da margem do talo. G. secção transversal do talo. Pallavicinia lyellii (Hook.) S.F. Gray. H. aspecto do gametófito. I. células da margem do talo. J. secção transversal do talo. Symphyogyna aspera Steph. ex McCormick. K. aspecto do gametófito feminino. L. aspecto do gametófito masculino. M. células da margem do talo. N. secção transversal do talo (A-D. Câmara 1986; E-G. Prado s.n. p.p.; H-J. O. Yano \& Wanderley 10650; K-N. Vital 1234) 
Chave para os gêneros

1. Células da margem mais longas que as demais, pêlos mucilaginosos marginais com 2-3 células compr.

1'. Células da margem pouco diferenciadas das demais, pêlos mucilaginosos ausentes ou quando presentes com apenas 1 célula compr.

\section{Pallavicinia A. Gray}

Gametófitos talosos, hábito prostrado, ramificações dicotômicas, talo dicotômica, nervura central bem diferenciada e nítida, secção transversal com porção central de células pequenas e espessadas, células quadrático-irregulares, células da margem iguais alongadas, rizóides monomórficos, pelos mucilaginosos marginais com 2-3 células, gametângios dorsais no caulídio, anterídios superfície do talo, arquegônios circundado por escamas, liso. Cápsula alongada.

1.1. Pallavicinia lyellii (Hook.) S.F. Gray, Nat. Arr. Brit. Plant. 1: 685. 1821.

Fig. $57 \mathrm{H}-\mathrm{J}$

Gametófitos talosos, verde-claros, hábito prostrado, ramificações dicotômicas, talo dicotômica, nervura central bem diferenciada e nítida, secção transversal com porção central de células pequenas e espessadas, células quadrático-irregulares, parede celular uniformemente delgada, cutícula lisa, trigônios ausentes, células da margem iguais alongadas, ocelos ausentes, rizóides monomórficos, restritos à base dos ramos, incolores, pelos mucilaginosos marginais com 2-3 células. Gametângios dorsais no caulídio, anterídios superfície do talo, arquegônios circundado por escamas, liso. Cápsula alongada.

Material examinado: Minas Gerais, Santana do Riacho, O. Yano \& Wanderley 10650, 10851, 10655 (SP220345; SP220544; SP220350); Dias Neto 110 p.p. (SP419747).

Associada a Fissidens pellucidus Hornsch. Ocorre nos estados de AC, AM, BA, CE, DF, GO, MS, MT, PA, RJ, RS, SC, SP e TO. Na Serra do Cipó, cresce em solo e rocha.

\section{Symphyogyna Nees \& Mont.}

Gametófitos talosos, verde-claros, hábito ascendente ou prostrado, ramificações dicotômicas, talo dicotômico, nervura central bem diferenciada e nítida, seç̧ão transversal com porção central de células pequenas e espessadas, células retangulares, quadráticas ou irregulares, rizóides monomórficos, restritos à base dos ramos, incolores, pelos mucilaginosos marginais ausentes ou com 1 células. Gametângios dorsais no caulídio, anterídios superfície do talo, arquegônios cobertos por uma única escama, liso, cápsula alongada.

Chave para as espécies

1. Gametófitos dendróides

1'. Gametófitos prostrados.

2. Margem do talo ondulada, formando lobos, células marginais iguais as da lâmina 2.3. S. podophylla

2'. Margem do talo não formando lobos, células marginais alongadas

2.1. Symphyogyna aspera Steph. ex McCormick, Bot. Gaz. 58: 403. 1914.

Fig. $57 \mathrm{~K}-\mathrm{L}$

Gametófitos talosos, verde-claros, hábito prostrado, ramificações dicotômicas, talo dicotômica, nervura central bem diferenciada e nítida, secção transversal com porção central de células pequenas e espessadas, células quadrático-irregulares, parede celular uniformemente delgada, cutícula lisa, trigônios ausentes, células da margem iguais as interiores, ocelos ausentes, anfigastro ausente, rizóides monomórficos, restritos à base dos ramos, incolores, pelos mucilaginosos marginais com 1 célula. Gametângios dorsais no caulídio, anterídios superfície do talo, arquegônios cobertos por uma única escama, liso, cápsula alongada.

Material examinado: Minas Gerais, Conceição do Mato Dentro, Vital 1234 (SP87128); O. Yano 535 (SP132051); Santana do Riacho, O. Yano \& Wanderley 10661 (SP220356).

Ocorre nos estados de AM, BA, CE, DF, ES, GO, MG, MS, MT, PA, PE, RJ, RS, SC e SP. Na Serra do Cipó, cresce em rocha e solo. Esta é uma espécie que apresenta $o$ hábito robusto e facilmente identificada pela irregularidade na porção laminar do gametófito, apresentando claramente ondulações. 
Flora da Serra do Cipó, Minas Gerais: Briófitas (Anthocerotophyta, Bryophyta e Marchantiophyta)

2.2. Symphyogyna brasiliense (Nees) Nees \& Mont., Ann. Sci. Nat. Bot. sér. 2, 5 :67. 1836.

Fig. 58 A-C

Gametófitos talosos, verde-claros, hábito prostrado, ramificações dicotômicas, talo dicotômica, nervura central bem diferenciada e nítida, secção transversal com porção central de células pequenas e espessadas, células retangulares, parede celular uniformemente delgada, cutícula lisa, trigônios ausentes, células da margem iguais as interiores, ocelos ausentes, anfigastro ausente, rizóides monomórficos, restritos à base dos ramos, incolores, pelos mucilaginosos marginais ausentes. Gametângios dorsais no caulídio, anterídios superfície do talo, arquegônios cobertos por uma única escama, liso, cápsula alongada.

Material examinado: Minas Gerais, Conceição do Mato Dentro, Vital 1225 (SP87125); O. Yano 483 (SP132040); Santana do Riacho, O. Yano \& Wanderley 10616 (SP220311); Câmara 1906 (SP419646).

Ocorre nos estados de BA, CE, DF, ES, GO, MG, MT, PR, RJ, RO, RR, RS, SC, SP e TO. Na Serra do Cipó, cresce em solo.

2.3. Symphyogyna podophylla (Thunb.) Mont. \& Nees in Gottsche et al., Syn. Hepat.: 481. 1846.

Fig. 58 D-G

Gametófitos talosos, verde-claros, hábito ascendente e dendróide, ramificações dicotômicas, talo dicotômica, nervura central bem diferenciada e nítida, secção transversal com porção central de células pequenas e espessadas, células quadráticoirregulares, parede celular uniformemente delgada, cutícula lisa, trigônios ausentes, células da margem iguais as interiores, ocelos ausentes, anfigastro ausente, rizóides monomórficos, restritos à base dos ramos, incolores, pelos mucilaginosos marginais ausentes. Gametângios dorsais no caulídio, anterídios superfície do talo, arquegônios cobertos por uma única escama, liso, cápsula alongada.

Material examinado: Minas Gerais, Santana do Riacho, O. Yano \& Wanderley 10644, 10658 (SP220339; SP220353); Pirani et al 5548 p.p. (SP388846, SPF).

Associada a Calypogeia laxa Lindenb. \& Gottsche e Telaranea diacantha (Mont.) J.J. Engel \& G.L. Merrill. Ocorre nos estados de AM, CE, ES, GO, MG, RJ, SC e SP. Na Serra do Cipó, cresce em rocha e solo. Esta é a única espécie deste gênero que apresenta o hábito dendróide.

\section{Pelliaceae}

É uma família amplamente distribuída nas regiões de planalto do Brasil, caracterizada principalmente pelo hábito robusto, prostrado e os filídios possuindo mais de um estrado na base. Ocorre principalmente como terrestre e rupícola. Ocorre apenas um gênero no Brasil e duas espécies, uma delas presente na Serra do Cipó.

Bibliografia básica: Gradstein \& Costa (2003); Gradstein et al. (2001); Yano \& Peralta (2008).

\section{Noteroclada Taylor ex Hook. \& Wilson}

Gametófitos folhosos, verde-claros, hábito prostrado, filídios súcubos, inserção longitudinal, inteiros, margem inteira, células quadrático-irregulares, parede celular uniformemente delgada, cutícula lisa, trigônios ausentes, ocelos ausentes, anfigastro ausente, rizóides incolores. Gametângios dorsais no caulídio, anterídios superfície do talo, arquegônios em pseudoperianto, liso, cápsula esférica.

1.1. Noteroclada confluens (Hook. f. \& Taylor) Spruce, Trans. \& Proc. Bot. Soc. Edinburgh 15: 531. 1885.

Fig. $58 \mathrm{H}-\mathrm{M}$

Gametófitos folhosos, verde-claros, hábito prostrado, pouco ou não ramificados, filídios súcubos, inserção longitudinal, inteiros, margem inteira, na região ventral reta, margem na região dorsal plana, sem células diferenciadas, células quadráticoirregulares, parede celular uniformemente delgada, cutícula lisa, trigônios ausentes, células da margem iguais as interiores, ocelos ausentes, anfigastro ausente, rizóides monomórficos, ao longo de toda a porção ventral, incolores. Gametângios dorsais no caulídio, anterídios superfície do talo, arquegônios em pseudoperianto, liso, cápsula esférica.

Material examinado: Minas Gerais, Conceição do Mato Dentro, Vital 7587 p.p., 7590, 7591 (SP132814; SP132817; SP132818); Jaboticatubas, Pirani et al. 6295 (SP432415); Santana do Riacho, Serra da Bandeirinha, $O$. Yano \& Wanderley 10896 (SP220589).

Associada a Marchantia chenopoda L. e Vesicularia vesicularis (Schwägr.) Broth. Ocorre nos estados de DF, ES, GO, MG, RJ, RS e SP. Na Serra do Cipó, cresce em solo.

\section{Plagiochilaceae}

É uma família amplamente distribuída no Brasil, caracterizada principalmente pelo hábito ascendente, filídios denteados com a margem distal do filídio incurvada e a proximal livre. Ocorre principalmente como corticícola e rupícola. Para a identificação das espécies é necessário análise da morfologia dos filídios e localização das estruturas reprodutivas. No Brasil ocorrem um gênero e 93 espécies; na Serra do Cipó ocorrem sete espécies.

Bibliografia básica: Gradstein \& Costa (2003); Gradstein et al. (2001); Lemos-Michel (2001); Heinrichs (2002); Yano \& Peralta (2008). 


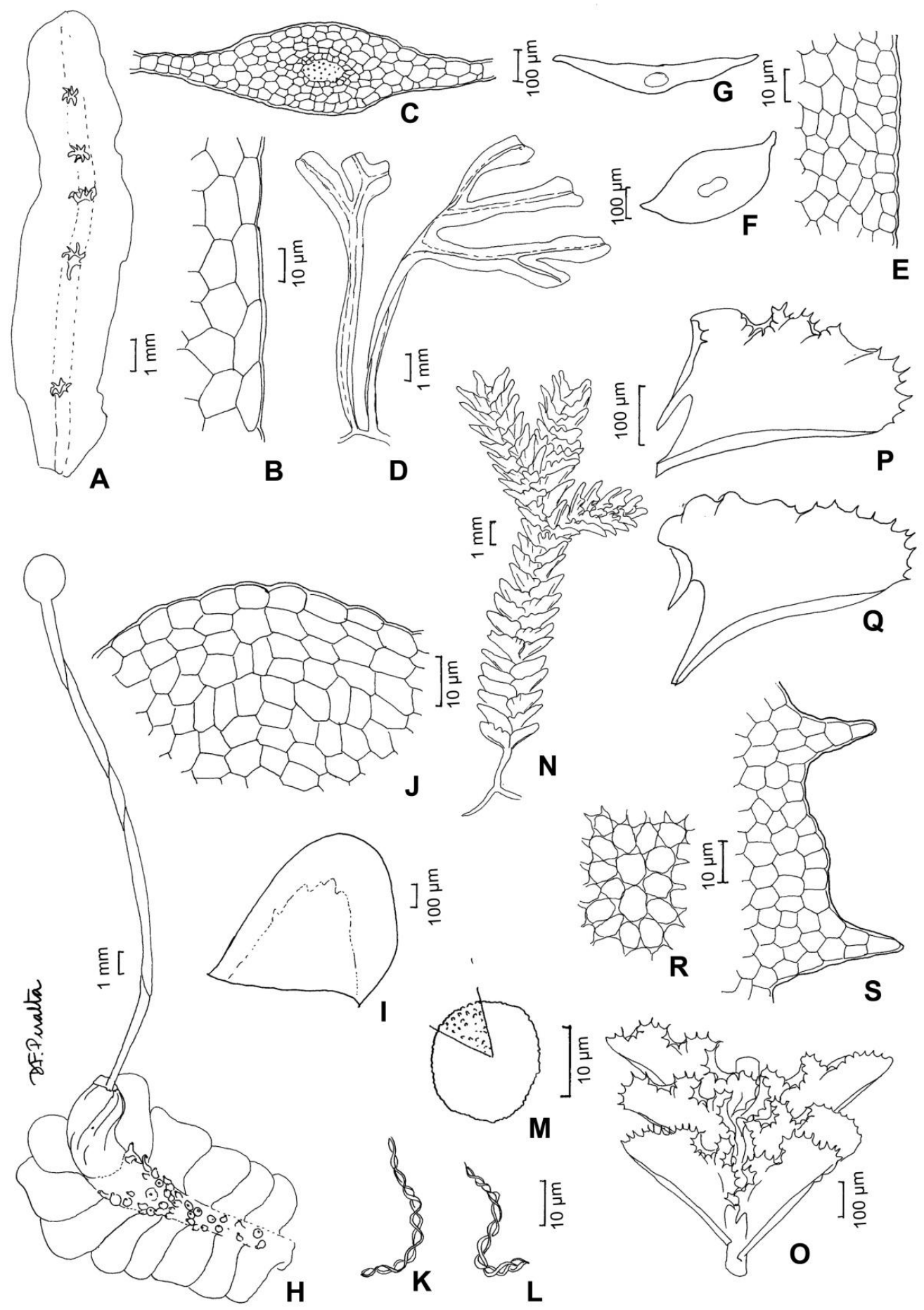

Fig. 58. Symphyogyna brasiliense (Nees) Nees \& Mont. A. aspecto do gametófito. B. células da margem do talo. C. secção transversal do talo. Symphyogyna podophylla (Thunb.) Mont. \& Nees. D. aspecto do gametófito. E. células da margem do talo. F-G. esquema da seç̧ão transversal do talo. Noteroclada confluens (Hook. f. \& Taylor) Spruce. H. aspecto do gametófito. I. filídio. J. células da margem do filídio. K-L. elatérios. M. esporo. Plagiochila corrugata (Nees) Nees \& Mont. N. aspecto do gametófito. O. detalhe do gametófito em vista ventral. P-Q. filídios. R. células da lâmina do filídio. S. dentes da margem do filídio (A-C. Vital 1225; D-G. O. Yano \& Wanderley 10644; H-M. O. Yano \& Wanderley 10896; N-S. O. Yano \& Wanderley 10731). 
Flora da Serra do Cipó, Minas Gerais: Briófitas (Anthocerotophyta, Bryophyta e Marchantiophyta)

\section{Plagiochila (Dumort.) Dumort.}

Gametófitos folhosos, marrons ou verdeescuros, estolões ausentes, hábito pendente ou ascendente, ramificações tipo Frullania. Filídios súcubos, longitudinalmente inseridos no caulídio, inteiros, denteados, margem na região ventral decurrente e na região dorsal plana ou involuta, sem células diferenciadas, células retangulares, quadráticas ou irregulares, parede celular uniformemente espessada, cutícula lisa, trigônios presentes ou ausentes, células da margem iguais as interiores, ocelos ausentes, anfigastro ausente ou pequenos (ca. 1 a $2 x$ larg. do caulídio), margem crenulada, denteada ou inteira, rizóides monomórficos, restritos à base dos ramos, incolores, gametângios terminais, anterídios em eixos especializados com filídios modificados, perianto lateralmente aplainado, cápsula esférica. Reprodução vegetativa por gemas na margem dos filídios.

Chave para as espécies

1. Filídios ligulados (mais ou menos a mesma largura na base e perto do ápice), porção ventral do filídio não cobrindo o caulídio.

2. Perianto sobre ramificações apicais, propagação vegetativa propágulos sobre os filídios; decurrente ...... 1.5. P. martiana

2'. Perianto sobre caulídios principais, propagação vegetativa não conhecida; não decurrente.

3. Filídios 1:3-4 x mais longos que largos; dentes no ápice dos filídios dois dentes predominantes 1.3. P. gymnocalycina

3'. Filídios 1:1-2 x mais longos que largos; dentes no ápice dos filídios uniformes e igualmente distribuídos.

4. Filídios maduros mais longos que largos 1.6. P. rutilans

4'. Filídios maduros mais ou menos quadráticos

1.7. P. simplex

1'. Filídios mais ou menos triangulares (muito mais largos na base do que próximo ao ápice); porção ventral do filídio cobrindo o caulídio.

5. Região ventral dos filídios fortemente crispada 1.1. P. corrugata

5'. Região ventral dos filídios plana ou ondulada.

6. Androécio intercalar; filídios 1:3-4 x mais longos que largos; dentes no ápice dos filídios dois dentes predominantes

6'. Androécio terminal em agrupamentos; filídios 1:1-2 x mais longos que largos; dentes no ápice dos filídios uniformes e igualmente distribuídos

1.1. Plagiochila corrugata (Nees) Nees \& Mont., Ann. Sci. Nat. Bot. sér. 2, 5: 52. 1836.

Fig. $58 \mathrm{~N}-\mathrm{S}$

Filídios mais ou menos triangulares (muito mais largos na base do que próximo ao ápice), região ventral dos filídios fortemente crispada, perianto sobre caulídios principais, propagação vegetativa não conhecida, porção ventral do filídio cobrindo o caulídio, decurrente, androécio terminal em agrupamentos, filídios 1:1-2 x mais longos que largos, dentes no ápice dos filídios uniformes e igualmente distribuídos.

Material examinado: Minas Gerais, Santana do Riacho, Serra da Bandeirinha, O. Yano \& Wanderley 10731 , 10749, 10765, 10766, 10791p.p., 10824, 10854 (SP220425 SP220443; SP220459; SP220460; SP220484; SP220517; SP220547); Prado s.n. (SP220629).

Associada a Schlotheimia rugifolia (Hook.) Schwägr. Ocorre nos estados de AC, BA, CE, DF, ES, GO, MG, PE, PR, RJ, RS, SC e SP. Na Serra do Cipó, cresce em tronco vivo. Esta é uma espécie comum e facilmente das demais espécies do gênero pela porção proximal do filídio amplamente ondulada.

1.2. Plagiochila cristata (Sw.) Lindenb., Spec. Hepat. fasc. 1: 33. 1839

Fig. 59 A-F

Filídios mais ou menos triangulares (muito mais largos na base do que próximo ao ápice), região ventral dos filídios plana ou ondulada, perianto sobre caulídios principais, propagação vegetativa não conhecida, porção ventral do filídio cobrindo o caulídio, decurrente, androécio intercalar, filídios 1:3-4 x mais longos que largos, dentes no ápice dos filídios dois dentes predominantes.

Material examinado: Minas Gerais, Santana do Riacho, Câmara 1960, 1966, 1967 (SP419673; SP419677; SP419678).

Ocorre nos estados do AC, AM, MG, PA, RJ, $\mathrm{SC}$ e SP. Na Serra do Cipó, cresce em tronco vivo. Esta espécie é facilmente identificada porque é a única do gênero que possui os filídio deltóidetriangulares. 

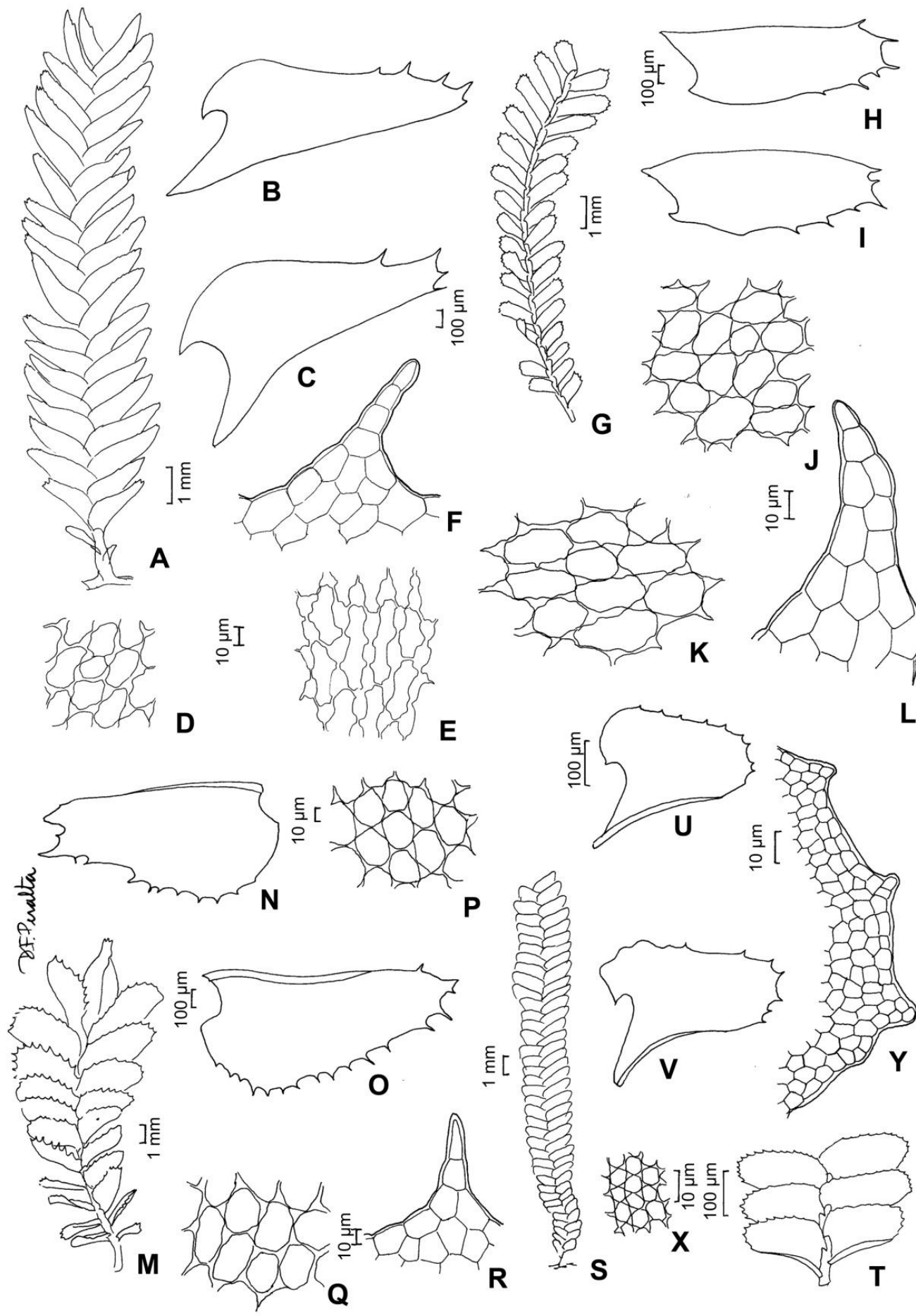

Fig. 59. Plagiochila cristata (Sw.) Lindenb. A. aspecto do gametófito. B-C. filídios. D. células da lâmina do filídio. E. células da base do filídio. F. dente da margem do filídio. Plagiochila gymnocalycina (Lehm. \& Lindenb.) Mont. G. aspecto do gametófito. HI. filídios. j. células da lâmina do filídio. K. células da base do filídio. L. dente da margem do filídio. Plagiochila macrostachya Lindenb. M. aspecto do gametófito. N-O. filídios. P. células da lâmina do filídio. Q. células da base do filídio. R. dente da margem do filídio. Plagiochila martiana (Nees) Lindenb. S. aspecto do gametófito. T. detalhe do gametófito em vista ventral. UV. filídios. X. células da lâmina do filídio. Y. margem do filídio (A-F. Câmara 1960; G-L. Dias Neto 152; M-R. Câmara et al. 2065 p.p.; S-Y. Pirani et al. 9747). 
Flora da Serra do Cipó, Minas Gerais: Briófitas (Anthocerotophyta, Bryophyta e Marchantiophyta)

1.3. Plagiochila gymnocalycina (Lehm. \& Lindenb.) Mont., d'Orbigny Voy. Amer. Mer. Bot. 7(2): 81. 1839.

Fig. 59 G-L

Filídios ligulados (mais ou menos a mesma largura na base e perto do ápice), região ventral dos filídios plana ou ondulada, perianto sobre caulídios principais, propagação vegetativa não conhecida, porção ventral do filídio não cobrindo o caulídio, não decurrente, androécio terminal em agrupamentos, filídios 1:3-4 x mais longos que largos, dentes no ápice dos filídios dois dentes predominantes.

Material examinado: Minas Gerais, Santana do Riacho, Dias Neto 152 (SP419776).

Ocorre nos estados do AC, AL, BA, ES, MG, PA, PE, RJ, SC e SP. Na Serra do Cipó, cresce em tronco vivo.

1.4. Plagiochila macrostachya Lindenb., Spec. Hepat. fasc. 2-4: 75. 1840.

Fig. $59 \mathrm{M}-\mathrm{R}$

Filídios mais ou menos triangulares (muito mais largos na base do que próximo ao ápice), região ventral dos filídios plana ou ondulada, perianto sobre caulídios principais, propagação vegetativa não conhecida, porção ventral do filídio cobrindo o caulídio, decurrente, androécio terminal em agrupamentos, filídios 1:1-2 x mais longos que largos, dentes no ápice dos filídios uniformes e igualmente distribuídos.

Material examinado: Minas Gerais, Santana do Riacho, Câmara et al. 2065 p.p. (SP419700).

Associada a Syzygiella anomala Steph. Ocorre nos estados de ES, GO, MG, RJ, SC e SP. Na Serra do Cipó, cresce em tronco caído.

1.5. Plagiochila martiana (Nees) Lindenb., Spec. Hepat. Fasc. 1: 12. 1839.

Fig. $59 \mathrm{~S}-\mathrm{V}$

Filídios ligulados (mais ou menos a mesma largura na base e perto do ápice), região ventral dos filídios plana ou ondulada, perianto sobre ramificações apicais, propagação vegetativa propágulos sobre os filídios, porção ventral do filídio não cobrindo o caulídio, decurrente, androécio terminal em agrupamentos, filídios 1:1-2 x mais longos que largos, dentes no ápice dos filídios uniformes e igualmente distribuídos.

Material examinado: Minas Gerais, Santana do Riacho, Pirani et al. 9747 (SP222587); Serra da Bandeirinha, O. Yano \& Wanderley 10838 (SP220531).

Ocorre nos estados de AC, AL, BA, CE, DF, ES, GO, MG, MS, MT, PA, PE, PR, RJ, RS, SC e SP. $\mathrm{Na}$ Serra do Cipó, cresce em solo.
1.6. Plagiochila rutilans Lindenb., Spec. Hepat. fasc. 2-4: 47. 1841.

Fig. 60 A-E

Filídios ligulados (mais ou menos a mesma largura na base e perto do ápice), região ventral dos filídios plana ou ondulada, perianto sobre caulídios principais, propagação vegetativa não conhecida, porção ventral do filídio não cobrindo o caulídio, não decurrente, androécio terminal em agrupamentos, filídios 1:1-2 x mais longos que largos, dentes no ápice dos filídios uniformes e igualmente distribuídos.

Material examinado: Minas Gerais, Santana do Riacho, Serra da Bandeirinha, O. Yano \& Wanderley 10845 p.p. (SP220538); Câmara 1934 (SP419654); Dias Neto 154 (SP419778).

Associada a Porotrichum longirostre (Hook.) Mitt. e Lopholejeunea nigricans (Lindenb.) Schiffn. Ocorre nos estados de AC, AM, AP, BA, CE, ES, GO, MG, MT, PA, PE, RJ, RR, RS, SC e SP. Na Serra do Cipó, cresce em tronco vivo.

1.7. Plagiochila simplex (Sw.) Lindenb., Spec. Hepat. fasc. 2-4: 54. 1840.

Fig. 60 F-J

Filídios ligulados (mais ou menos a mesma largura na base e perto do ápice), região ventral dos filídios plana ou ondulada, perianto sobre caulídios principais, propagação vegetativa não conhecida, porção ventral do filídio não cobrindo o caulídio, não decurrente, androécio terminal em agrupamentos, filídios 1:1-2 x mais longos que largos, dentes no ápice dos filídios uniformes e igualmente distribuídos.

Material examinado: Minas Gerais, Santana do Riacho, Serra da Bandeirinha, O. Yano \& Wanderley 10859 p.p., 10865 (SP220552; SP220558); Dias Neto 168 (SP419787).

Associada a Cheilolejeunea rigidula (Mont.) R.M. Schust. e C. unciloba (Lindenb.) Malombe. Ocorre nos estados de AL, AM, BA, GO, MG, PA, PE, RJ e SP. Na Serra do Cipó, cresce em tronco caído e rocha.

\section{Porellaceae}

É uma família amplamente distribuída nas áreas de planalto do Brasil, caracterizada principalmente pela morfologia do lóbulo que é livre e paralelo ao caulídio. Ocorre principalmente como corticícola. Para a identificação das espécies é necessário análise da morfologia do lóbulo e anfigastro. No Brasil ocorre um gênero e sete espécies, apenas uma delas encontrada na Serra do Cipó. 


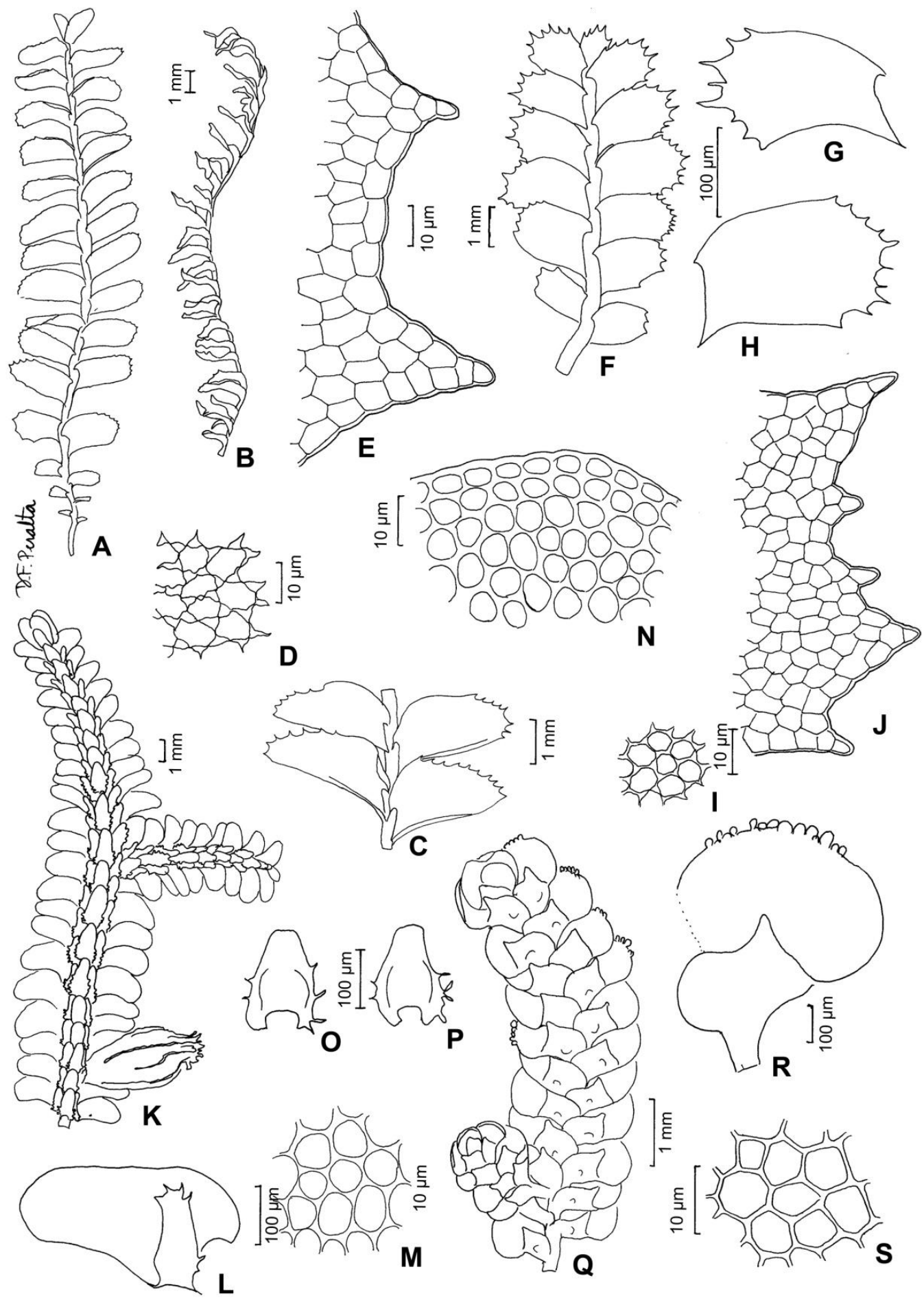

Fig. 60. Plagiochila rutilans Lindenb. A. aspecto do gametófito. B. aspecto do gametófito seco. C. detalhe do gametófito em vista ventral. D. células da lâmina do filídio. E. margem do filídio. Plagiochila simplex (Sw.) Lindenb. F. aspecto do gametófito. G-H. filídios. I. células da lâmina do filídio. J. margem do filídio. Porella brasiliensis (Raddi) Schiffn. K. aspecto do gametófito. L. filídio. M. células da lâmina do filídio. N. margem do filídio. O-P. anfigastro. Radula quadrata Gottsche. Q. aspecto do gametófito. R. filídios. S. células da lâmina do filídio (A-E. O. Yano \& Wanderley 10845 p.p.; F-J. O. Yano \& Wanderley 10859 p.p.; K-P. O. Yano \& Wanderley 10892.; Q-S. O. Yano \& Wanderley 10878 p.p.). 
Bibliografia básica: Gradstein \& Costa (2003); Gradstein et al. (2001); Lemos-Michel (2001); So (2005); Swails Jr. (1970); Yano \& Peralta (2008).

\section{Porella L.}

Gametófitos folhosos, marrons ou verdeescuros. Filídios íncubos, inserção longitudinal, inteiros, margem inteira, na região ventral lobulada (lóbulo paralelo ao caulídio), células hexagonais, anfigastro inteiro, denteado na base, grandes, rizóides monomórficos, em tufos na base dos anfigastros, incolores. Gametângios laterais em pequenas ramificações, anterídios em eixos especializados com filídios modificados, perianto quilhado, cápsula esférica. Reprodução vegetativa desconhecida.

1.1. Porella brasiliensis (Raddi) Schiffn., Nova Acta Acad. Caes. Leop. Carol. German. Nat. Cur. 60: 246. 1893.

Fig. $60 \mathrm{~K}-\mathrm{P}$

Gametófitos folhosos, marrons ou verdeescuros, hábito pendente ou ascendente, ramificações tipo Frullania. Filídios íncubos, inserção longitudinal, inteiros, margem inteira, na região ventral lobulada (lóbulo paralelo ao caulídio), margem na região dorsal plana, sem células diferenciadas, células hexagonais, parede celular uniformemente espessada, cutícula lisa, trigônios presentes, células da margem iguais as interiores, ocelos ausentes, anfigastros inteiros, grandes (ca. 3 a 10x larg. do caulídio), denteados na base, rizóides monomórficos, em tufos na base dos anfigastros, incolores. Gametângios laterais em pequenas ramificações, anterídios em eixos especializados com filídios modificados, perianto quilhado.

Material examinado: Minas Gerais, Santana do Riacho, Serra da Bandeirinha, O. Yano \& Wanderley 10892 (SP220585).

Ocorre nos estados de DF, GO, MG, PR, RJ, RS, SC e SP. Na Serra do Cipó, cresce em tronco vivo.

\section{Radulaceae}

É uma família amplamente distribuída no Brasil, caracterizada principalmente pelo hábito prostrado dos caulídios primários e ascendente dos secundários e a ausência de anfigastro. Ocorre principalmente como corticícola e rupícola. Para a identificação das espécies é necessário análise da morfologia do lóbulo. No Brasil ocorre um gênero e 34 espécies, apenas uma delas encontrada na Serra do Cipó.
Bibliografia básica: Gradstein \& Costa (2003); Gradstein et al. (2001); Yano \& Peralta (2008).

\section{Radula Dumort.}

Gametófitos folhosos, verde-escuros. Filídios íncubos, inserção longitudinal, inteiros, margem inteira, na região ventral lobulada, células hexagonais, parede celular uniformemente delgada, cutícula lisa, trigônios ausentes, ocelos ausentes, anfigastro ausente. Gametângios laterais em pequenas ramificações, anterídios em eixos especializados com filídios modificados, perianto lateralmente aplainado, cápsula esférica.

1.1. Radula quadrata Gottsche in Gottsche et al., Syn. Hepat.: 255. 1844.

Fig. 60 Q-S

Gametófitos folhosos, verde-escuros, hábito prostrado, ramificações lateral intercalar. Filídios íncubos, inserção longitudinal, inteiros, margem inteira, na região ventral lobulada (ângulo reto ao caulídio), na região dorsal plana, sem células diferenciadas, células hexagonais, parede celular uniformemente delgada, cutícula lisa, trigônios ausentes, células da margem iguais as interiores, ocelos ausentes, anfigastro ausente, rizóides monomórficos, em tufos na base dos lóbulos, incolores. Gametângios laterais em pequenas ramificações, anterídios em eixos especializados com filídios modificados, perianto lateralmente aplainado, cápsula esférica. Reprodução vegetativa por gemas na margem dos filídios.

Material examinado: Minas Gerais, Santana do Riacho, Serra da Bandeirinha, O. Yano \& Wanderley 10878 p.p. (SP220571).

Associada a Lejeunea flava (Sw.) Nees. Ocorre nos estados de BA, GO, MG, PA, PR, RJ, RS e SP. $\mathrm{Na}$ Serra do Cipó, cresce em tronco vivo. Esta espécie á facilmente diferenciada das demais do gênero por apresentar inúmeras gemas na margem do filídio e o lóbulo quadrado.

\section{Agradecimentos}

O professor e amigo Dr. José Rubens Pirani pelo incentivo, todo o apoio durante a revisão do material do herbário SFP e ao Curador do herbário UB pelo envio de boa parte das amostras analisadas. 


\section{Referências}

ALLEN, B.H. 1994. Moss Flora of Central America. Part 1. Sphagnaceae-Calymperaceae. Monographs in Systematic Botany from the Missouri Botanical Garden 49: 1-242.

ALLEN, B.H. 2002. Moss flora of Central America, Part 2. Encalyptaceae-Orthotrichaceae. Monographs in Systematic Botany from the Missouri Botanical Garden 90: 1-699.

ALLEN, B.H. 2010. Moss Flora of Central America. Part 3. Anomodontaceae-Symphyodontaceae. Monographs in Systematic Botany from the Missouri Botanical Garden 117: 1-731.

BASTOS, C.J.P. 2004. Lejeuneaceae (Marchantiophyta) no estado da Bahia, Brasil. Tese de Doutorado. Instituto de Biociências, Universidade de São Paulo. 442 p.

BISCHLER, H., BONNER, C.E.B. \& MILLER, H.A. 1963. Studies in Lejeuneaceae VI. The genus Microlejeunea Steph in Central and South America. Nova Hedwigia 5: 359-411.

BISCHLER-CAUSSE, H., GRADSTEIN, S.R., JOVET-AST, S., LONG, D.G. \& SALAZAR-ALLEN, N. 2005. Marchantiiae. Flora Neotropica, monograph 97: 1-262.

BUCK, W.R. 1998. Pleurocarpous mosses of the West Indies. Memoirs of The New York Botanical Garden 82: 1-400.

BUCK, W.R. 2003. Guide to the plants of Central French Guiana. Part. 3. Mosses. Memoirs of The New York Botanical Garden 76(3): 1-176.

BUCK, W.R. \& GOFFINET, B. 2000. Morphology and classification of mosses. In: A.J. SHAW \& B. GOFFINET (eds.). Bryophyte Biology. Cambridge University Press, Cambridge, pp. 71-123.

COSTA, D.P. 1999. Metzgeriaceae (Metzgeriales, Hepatophyta) no Brasil. Tese de Doutorado. Instituto de Biociências, Universidade de São Paulo. 261 p.

COSTA, D.P. 2008. Metzgeriaceae (Hepaticae). Flora Neotropica, monograph 102: 1-169.

COSTA, D.P. \& PÔRTO, K.C. 2003. Estado da arte das coleções de briófitas no Brasil. pp. 75-98. In: A.L. PEIXOTO (org.). Coleções Biológicas de Apoio ao Inventário, Uso Sustentável e Conservação da Biodiversidade. Instituto de Pesquisas Jardim Botânico do Rio de Janeiro, Rio de Janeiro.

COSTA, D.P., IMBASSAHY, C.A.A. \& SILVA, V.P.A.V. 2005 Checklist and distribution of mosses, liverworts and hornworts of Rio de Janeiro State, Brazil. The Journal of the Hattori Botanical Laboratory 98: 259-298.

COSTA, D.P., ALMEIRA, J.S.S., DIAS, N.S., GRADSTEIN, S.R. \& CHURCHILL, S.P. 2010. Manual de Briologia. Editora Interciência.

CHURCHILL, S.P. 1994. The mosses of Amazonian Ecuador. AAU Reports 35: 1-211.
CRANDALL-STOTLER, B. \& STOTLER, R. 2000. Morphology and classification of the Marchantiophyta. In: A.J. SHAW e B. GOFFINET (Eds.): Bryophyte Biology: Cambridge University Press, England, p. 21-70.

CRUM, H. 1994. Sphagnopsida. Sphagnaceae. North American Flora. ser. 2, 11: 1-180.

DELGADILLO, C.M. 1994. Endemism in the neotropical moss flora. Biotropica 26: 12-16.

ENGEL, J.J. \& SMITH MERRILL, G.L. 2004. Austral Hepaticae 35. A taxonomic and phylonetic study of Telaranea (Lepidoziaceae), with a monograph of the genus in temperate Australasia and commentary on extra-Australasian taxa. Fieldiana Botany 44: 1-265.

FORZZA, R.C., LEITMAN, P.M., COSTA, A.F., CARVALHO JR., A.A., PEIXOTO, A.L., WALTER, B.M.T., BICUDO, C., ZAPPI, D., COSTA, D.P., LLERAS, E., MARTINELLI, G., LIMA, H.C., PRADO, J., STEHMANN, J.R., BAUMGRATZ, J.F.A., PIRANI, J.R., SYLVESTRE, L., MAIA, L.C., LOHMANN, L.G., QUEIROZ, L.P., SILVEIRA, M., COELHO, M.N., MAMEDE, M.C., BASTOS, M.N.C., MORIM, M.P., BARBOSA, M.R., MENEZES, M., HOPKINS, M., SECCO, R., CAVALCANTI, T.B. \& SOUZA, V.C. 2010. Introdução. In: Lista de Espécies da Flora do Brasil. Jardim Botânico do Rio de Janeiro. Vol. 1. Jardim Botânico do Rio de Janeiro. 875 p.

FRAHM, J.-P. 1991. Dicranaceae: Campylopodioideae, Paraleucobryoideae. Flora Neotropica, monograph 54: $1-238$.

FRAHM, J.-P. (ed.) 2003. Manual of Tropical Bryology. Tropical Bryology 23: 1-195.

FULFORD, M.H. 1963. Manual of the leafy Hepaticae of Latin America. Memoirs of The New York Botanical Garden 11(1): 1-172.

FULFORD, M.H. 1966. Manual of the leafy Hepaticae of Latin America. Memoirs of The New York Botanical Garden 11(2): 173-276.

FULFORD, M.H. 1968. Manual of the leafy Hepaticae of Latin America. Memoirs of The New York Botanical Garden 11(3): 277-392.

FULFORD, M.H. 1976. Manual of the leafy Hepaticae of Latin America. Memoirs of The New York Botanical Garden 11(4): 393-535.

GIULIETTI, A.M., MENEZES, N.L., PIRANI, J.R., MEGURO, M. \& WANDERLEY, M.G.L. 1987. Flora da Serra do Cipó, Minas Gerais: caracterização e lista das species. Boletim de Botânica da Universidade de São Paulo 9: 1-151.

GRADSTEIN, S.R. 1994. Lejeuneaceae: Ptychantheae, Brachiolejeuneae. Flora Neotropica, monograph 62: 1216

GRADSTEIN, S.R. \& COSTA, D.P. 2003. The Hepaticae and Anthocerotae of Brazil. Memoirs of The New York Botanical Garden 87: 1-318. 
Flora da Serra do Cipó, Minas Gerais: Briófitas (Anthocerotophyta, Bryophyta e Marchantiophyta)

GRADSTEIN, S.R. \& ILKIU-BORGES, A.L. 2009. Guide to the plants of Central French Guiana. Memoirs of The New York Botanical Garden 76(4): 1-140.

GRADSTEIN, S.R., CHURCHILL, S.P. \& SALAZAR-ALLEN, N. 2001. Guide to the Bryophytes of Tropical America. Memoirs of The New York Botanical Garden 86: 1-577.

GROOMBRIDGE, B. (ed.) 1992. Global biodiversity: status of the Earth's living resources: a report compiled by the World Conservation Monitoring Centre. Chapman \& Hall, London.

HÄSSEL DE MENÉNDEZ, G.G. 1962. Estúdio de las Anthocerotales y Marchantiales de la Argentina. Opera Lilloana 7: 1-297.

HEINRICHS, J. 2002. A taxonomic revision of Plagiochila sect. Hylacoetes, sect. Adiantoideae and sect. Fuscolutae in the Neotropics with a preliminary subdivision of Neotropical Plagiochilaceae into nine lineages. Bryophytorum Bibliotheca 58: 1-184.

HELL, K.G. 1969. Briófitas talosas dos arredores da cidade de São Paulo, Brasil. Boletim da Faculdade de Filosofia da Universidade de São Paulo, Botânica 25: 1-187.

IRELAND, R.R. \& BUCK, W.R. 1994. Stereophyllaceae. Flora Neotropica, monograph 65: 1-50.

IRELAND, R.R. \& BUCK, W.R. 2009. Some Latin American genera of Hypnaceae (Musci). Smithsonian Contributions to Botany 93: 1-97.

LEMOS-MICHEL, E. 2001. Hepáticas epifíticas sobre o Pinheiro-Brasileiro no Rio Grande do Sul. Editora da Universidade Federal do Rio Grande do Sul, Porto Alegre. $191 \mathrm{p}$.

LEWINSOHN, T.M. \& PRADO, P.I. 2000. Biodiversidade Brasileira: Síntese do Estado Atual do Conhecimento. Brasília, MMA.

LUIZI-PONZO, A.P., BASTOS, C.J.P., COSTA, D.P., PÔRTO, K.C., CÂMARA, P.E.A.S., LISBOA, R.C.L. \& VILAS-BÔAS BASTOS, S.B. 2006. Glossarium polyglotum bryologiae: versão brasileira do glossário briológico. Editora da Universidade Federal de Juiz de Fora, Juiz de Fora. $114 \mathrm{p}$.

OCHI, H. 1980. A revision of the Neotropical Bryoideae, Musci (First Part). The Journal of the Faculty of Education Tottori University, nat. Sci. 29(2): 49-145.

OCHI, H. 1981. A revision of the Neotropical Bryoideae, Musci (Second Part). The Journal of the Faculty of Education Tottori University, nat. Sci. 30: 21-55.

PEDERSEN, N. 2005. Validation of Imbibryum (Bryaceae). The Bryologist 108: 449.

PERALTA, D.F. \& YANO, O. 2010. Taxonomic treatment of the Polytrichaceae from Brazil. The Bryologist 113(3): 646-672.

PURSELL, D.F. 2007. Fissidentaceae. Flora Neotropica, monograph 101: 1-278.

REESE, W.D. 2003. Calymperaceae. Flora Neotropica, monograph 58: 1-102.
REINER-DREHWALD, M.E. 2000. Las Lejeuneaceae (Hepaticae) de Misiones, Argentina VI. Lejeunea y Taxilejeunea. Tropical Bryology 19: 81-131.

SCHUSTER, R.M. 1980. The Hepaticae and Anthocerotae of North America east of the hundredth meridian. Columbia University Press, New York. Vol 4: 1-1334.

SCHUSTER, R.M. 1992. The Hepaticae and Anthocerotae of North America east of the hundredth meridian. Chicago, Field Museum of Natural History. vol. 6: 1-937.

SEHNEM, A. 1978. Musgos Sul-brasileiros V. Pesquisas, Bot. 32: $1-170$.

SHARP, A.J., CRUM, H. \& ECKEL, P.M. 1994. The moss flora of Mexico. Memoirs of The New York Botanical Garden 69(1-2): 1-1113.

SHEPHERD, G.J. 2003. Plantas terrestres: Versão preliminar. Relatório de Avaliação do estado do conhecimento da diversidade biológica do Brasil. $60 \mathrm{p}$.

SO, M.L. 2005. Porella (Porellaceae, Marchantiophyta) in Latin America. New Zealand Journal of Botany 43: 201321.

SPENCE, J.R. \& RAMSAY, H.P. 2005. New genera and combinations in the Bryaceae (Bryales, Musci) for Australia. Phytologia 87(2): 61-72.

STOTLER, R.E. 1970. The genus Frullania subgenus Frullania in Latin America. Nova Hedwigia 18: 397-555.

STOTLER, R.E. \& CRANDALL-STOTLER, B. 2005. A revised classification of the Anthocerotophyta and a checklist of the hornworts of North America, North of Mexico. The Bryologist 108: 16-26.

SWAILS Jr., L.F. 1970. The genus Porella in Latin America. Lehre, Verlag J. Cramer. 291p.

TAN, B.C. \& PÓCS, T. 2000. Bryogeography and conservation of bryophytes. In: A.J. SHAW \& B. GOFFINET (eds.). Bryophyte Biology, Cambridge University Press, pp. 403-448.

VAZ, T.F. \& COSTA, D.P. 2006. Os gêneros Brymela, Callicostella, Crossomitrium, Cyclodictyon, Hookeriopsis, Hypnella e Trachyxiphyum (Pilotrichaceae, Bryophyta) no Estado do Rio de Janeiro, Brasil. Acta Botanica Brasilica 20(4): 955-973.

VIANNA, E.C. 1985. Marchantiales. Flora llustrada do Rio Grande do Sul. Boletim do Instituto Central de Biociências, Porto Alegre 38: 1-213.

VITAL, D.M. 1980. Erpodiaceae (Musci) do Brasil. Dissertação de Mestrado. Universidade Estadual de Campinas, UNICAMP. 1-135 p.

YANO, O. 1979. Contribuição ao inventário dos Musci Brasileiros: Helicophyllaceae. Rickia 8: 7-16.

YANO, O. 1981. A checklist of Brazilian mosses. Journal of the Hattori Botanical Laboratory 50: 279-456.

YANO, O. 1984a. Checklist of Brazilian liverworts and hornworts. Journal of the Hattori Botanical Laboratory 56: 481-548. 
YANO, O. 1984b. Contribuição ao inventário dos Musci Brasileiros: 3. Racopilaceae (Bryopsida, Isobryales). Revista Brasileira de Botânica 7(1): 57-63.

YANO, O. 1985. Contributição ao inventário dos Musci Brasileiros: 4. Rhachitheciaceae. Rickia 12: 29-34.

YANO, O. 1986. Contribuição ao inventário dos Musci Brasileiros: 5. Rhizogoniaceae (Bryopsida). Rickia 13: 46-60.

YANO, O. 1987. Bryophyta. In: A.M. GIULIETTI, N.L. MENEZES, J.R. PIRANI, M. MEGURO \& M.G.L. WANDERLEY. Flora da Serra do Cipó, Minas Gerais: caracterização e lista das espécies. Boletim de Botânica da Universidade de São Paulo 9: 11-12.

YANO, O. 1989. An additional checklist of Brazilian bryophytes. The Journal of the Hattori Botanical Laboratory 66: 371-434.

YANO, O. 1992. Leucobryaceae (Bryopsida) do Brasil. Tese de Doutorado. Instituto de Biociências, Universidade de São Paulo. 318 p.

YANO, O. 1995. A new additional annotated checklist of Brazilian bryophytes. The Journal of the Hattori Botanical Laboratory 78: 137-182.

YANO, O. 1998. Briófitas do estado de São Paulo. In: C.E.M. BICUDO \& G.J. SHEPHERD (eds.). Biodiversidade do estado de São Paulo, Brasil - Síntese do conhecimento ao final do século $X X$ 2: Fungos macroscópicos e plantas, São Paulo 2: 37-46.

YANO, O. 2006. Novas adições ao catálogo das briófitas brasileiras. Boletim do Instituto de Botânica 17: 1-142.

YANO, O. 2008. Catálogo dos antóceros e hepáticas brasileiras: literatura original, basiônimo, localidade-tipo e distribuição geográfica. Boletim do Instituto de Botânica 19: 1-110.

YANO, O. 2010. Levantamento de novas ocorrências de briófitas brasileiras. Publicação on line do Instituto de Botânica. CDU582.32/WWW.ibot.sp.gov.br/ Briófitas Brasileiras/Briófitas MIOLO E CAPA.pdf.

YANO, O. 2011. Catálogo de Musgos Brasileiros: literatura original, basiônimo, localidade-tipo e distribuição geográfica. Publicação on line do Instituto de Botânica. CDU582.32/ http://www.ibot.sp.gov.br/publicacoes/virtuais/musgos\%20br asileros\%20completo\%2023-05.pdf.
YANO, O. \& COSTA, D.P. 2000. Briófitas. In: I.F. Pereira Campos (Coord.). Flora dos Estados de Goiás e Tocantins. Criptágamos. Goiânia: Editora UFG. Vol. 5: 1-33.

YANO, O. \& MELLO, Z.R. 1989. Estudos de Briófitas do Brasil: 6. Phyllogoniaceae (Brypsida). Acta Botanica Brasilica 3(2): 119-129.

YANO, O. \& OLIVEIRA-E-SILVA, M.I.M.N. 1997. Criptógamos do Parque Estadual das Fontes do Ipiranga, São Paulo, SP. Briófitas 2: Fissidentaceae (Bryales). Hoehnea 24(2): 107-114.

YANO, O. \& PERALTA, D.F. 2007. Musgos (Bryophyta). In: J.A. RIZZO (coord.) Flora dos Estados de Goiás e Tocantins. Criptógamos. Goiânia: PRPPG/UFG. Vol. 6. 333P.

YANO, O. \& PERALTA, D.F. 2008. Antóceros (Anthocerotophyta) e Hepáticas (Marchantiophyta). In: J.A. Rizzo (coord.) Flora dos Estados de Goiás e Tocantins. Criptógamos. Goiânia: PRPPG/UFG. Vol. 7: $1-277$.

YANO, O. \& PERALTA, D.F. 2009. Flora de Grão-Mogol, Minas Gerais. Briófitas (Bryophyta e Marchantiophyta). Boletim da Universidade de São Paulo, Botânica 27(1): 1-26.

YANO, O., PIRANI, J.R. \& SANTOS, D.P. 1985. O gênero Sphagnum (Bryopsida) nas regiões Sul e Sudeste do Brasil. Revista Brasileira de Botânica 8(1): 55-80.

YUZAWA, Y. \& KOIKE, N. 1989. Studies on the Type specimens of Latin America Frullania species (1). The Journal of the Hattori Botanical Laboratory 66: 343-358.

ZANDER, R.H. 1993. Genera of the Pottiaceae: mosses of harsh enviroments. Bulletin of the Buffalo Society of Natural Sciences 32: 1-378.

ZARTMAN, C.E. \& ILKIU-BORGES, A.L. 2007. Guia para as briófitas epífilas da Amazônia Central. Manaus. Editora INPA. 140 p. 
Índice de gêneros

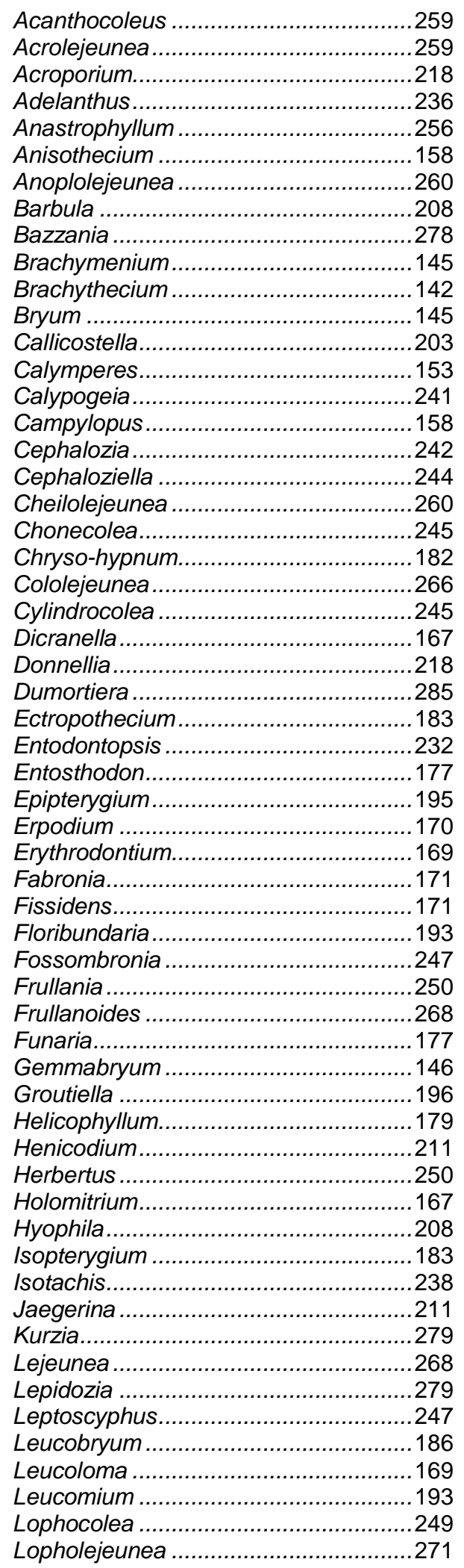

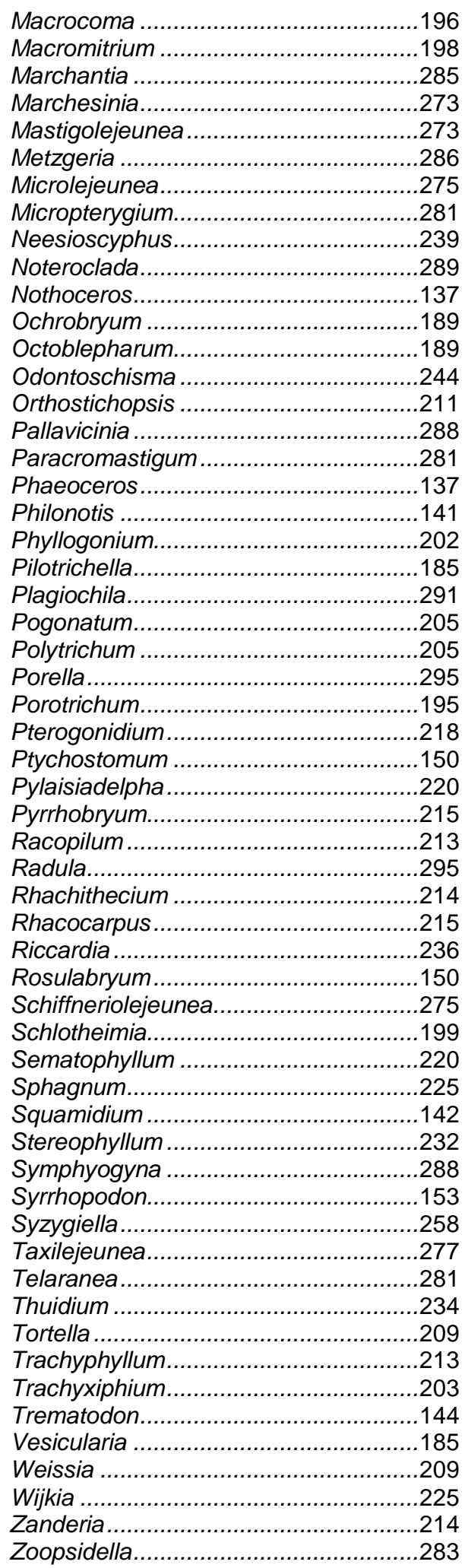

